\title{
Vozes da Cratera: representações, sentidos, significados e práticas da questão socioambiental no cenário urbano
}

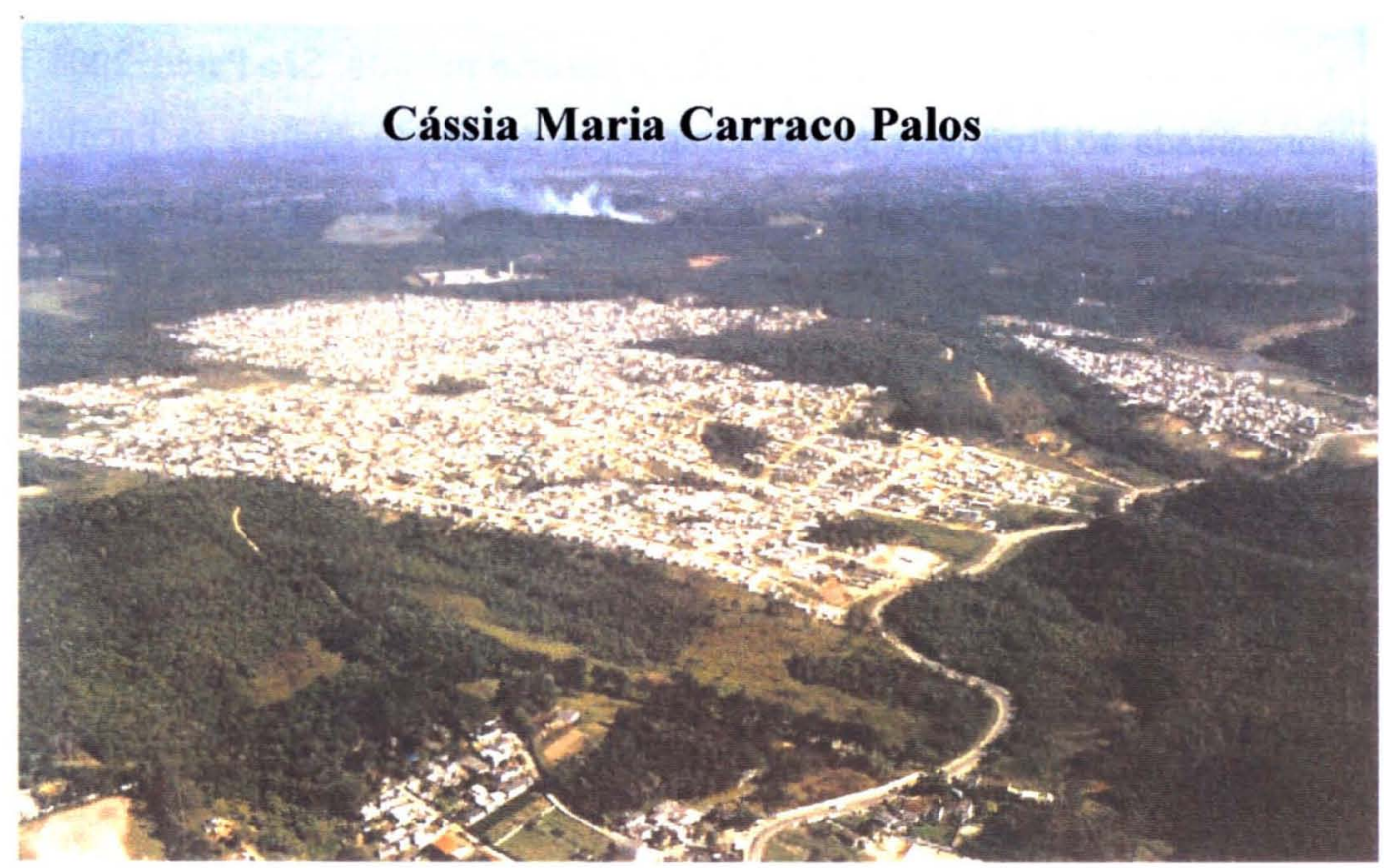

Tese apresentada ao Programa de Pós-Graduação em Saúde Pública da Faculdade de Saúde Pública da Universidade de São Paulo para obtenção do título de Doutora em Saúde Pública.

Área de Concentração: Serviços de Saúde Pública Orientadora: Prof ${ }^{\mathrm{a}}$. Dr ${ }^{\mathrm{a}}$. Fabíola Zioni

São Paulo 2004

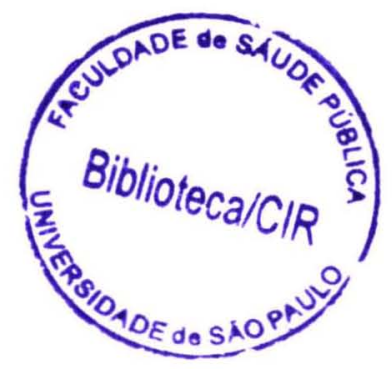


Ficha Catalográfica:

Palos CMC. Vozes da Cratera: representações, sentidos, significados e práticas da questão socioambiental no cenário urbano. São Paulo; 2004. [Tese apresentada ao Programa de Pós-Graduação em Saúde Pública da Faculdade de Saúde Pública da Universidade de São Paulo para obtenção do título de Doutora em Saúde Pública].

Autorizo, exclusivamente para fins acadêmicos e científicos, a reprodução total ou parcial desta tese, por processos fotocopiadores.

Nome:

Data: 
As minhas filhas Mariana, Ana Carolina e luiza.

AO MEU FILHO THIAGo (IN MEMORIAM)

À MINHA AVÓ MARIA ROSA, COM QUEM APRENDI AMAR A NATUREZA. 


\section{AGRADECIMENTOS}

Às mulheres e homens da Cratera da Colônia, especialmente ao pessoal do Condomínio Habitacional Vargem Grande pela paciência, disponibilidade e pelo carinho com que me receberam em suas casas e, principalmente por tudo que me ensinaram com seus relatos e reflexões.

A Avarilda e ao João (in memoriam), pela disponibilidade e pelo apoio, sem os quais esta tese não seria possível.

Ao Sr. Sebastião Carmo da Silva pela disponibilidade e entusiasmo, e a todo o pessoal da ACHAVE pelas valiosas contribuições.

À minha orientadora Professora Dr ${ }^{a}$ Fabíola Zioni pelo apoio, estímulo, confiança e competência com que orientou este trabalho.

À Professora Titular Helena Ribeiro, ao Professor Titular Ladislau Dowbor, à Professora $\mathrm{Dr}^{\mathrm{a}}$ Eda Terezinha Tassara, ao Professor Associado Arlindo Philippi Jr e à professora $\mathrm{Dr}^{\mathrm{a}}$ Wanda Risso Günther, membros da Comissão Julgadora desta tese de doutorado, pela atenção e dedicação com que leram a minuta deste trabalho, oferecendo valiosas e significativas contribuições para sua versão final.

À Milagros Garcia e Jesus Canelon, meus amigos queridos, cuja interlocução estimulante e inteligente foi um privilégio compartilhar.

À querida amiga Joyce Maria de Araújo pela dedicação, pelo estímulo e pelo auxílio em tornar minha redação melhor.

Às amigas queridas Dilmara Veríssimo de Souza, Ruth Teresinha Kehrig, Vera Eterovic, Guadalupe Garcia e Cristiane Locatelli que, de distintas maneiras, estiveram comigo nesta tarefa e me fizeram sentir entre companheiras solidárias.

À colega e amiga Lucimara Barbosa, pela dedicação e valiosa contribuição na edição gráfica desta tese.

A todas as companheiras e companheiros do Instituto Fonte, especialmente Rogério Renato Silva e Daniel Brandão, pela compreensão, pelo incentivo e apoio. 
Aos professores e servidores da Faculdade de Saúde Pública da Universidade de São Paulo com quem convivi e, de quem desfrutei das maiores atenções e gentilezas no transcorrer de todo o curso de pós-graduação, em especial, ao pessoal da secretaria Renilda, Maria Aparecida, Márcia, Ângela e Mila que, com eficiência e presteza, muito me ajudaram nas diversas situações em que necessitei.

À querida Jucineide Nogueira de Melo, a "Neide" pelo carinho e bom humor, com que vem assumindo a responsabilidade de quase todo o "trabalho invisível" com relação à organização da casa, sem o qual este trabalho, com certeza, não teria saído. Ao universo de pessoas queridas e amigas não citadas, mas que, cedendo-me tempoespaço em suas vidas, investiram no meu empreendimento demonstrando solidariedade e afeto, a todas elas os mais profundos agradecimentos.

Ao Zé Carlos que a sua maneira contribuiu para a minha trajetória acadêmica. À FAPESP, que auxiliou o empreendimento deste trabalho. 


\section{RESUMO}

Palos CMC. Vozes da Cratera: representações, sentidos, significados e práticas da questão socioambiental no cenário urbano. São Paulo; 2004. [Tese apresentada ao Programa de Pós-Graduação em Saúde Pública da Faculdade de Saúde Pública da Universidade de São Paulo para obtenção do título de Doutora em Saúde Pública].

Neste início de século, a questão socioambiental confirma-se como uma preocupação mundial. Enfrentar os problemas ambientais nos grandes centros urbanos constitui-se em desafio para a sociedade política e para a sociedade civil. No âmbito da sociedade civil, os movimentos denominados associativismos civis e os movimentos sociais vêm mostrando formas inovadoras para lidar com a questão ambiental.

Esta pesquisa teve como objetivo compreender e analisar a questão socioambiental estabelecida na Cratera da Colônia, estrutura geológica situada no subdistrito de Parelheiros, Município e Estado de São Paulo, Brasil, do ponto de vista das representações, sentidos, significados e práticas de homens e mulheres, membros do Condomínio Vargem Grande, originado em uma ocupação clandestina.

Para abordar o tema em questão optou-se por uma pesquisa social, inspirada na sociologia ambiental, e em diálogo com outras áreas da ciência, numa perspectiva transdisciplinar, a qual foi desenvolvida em cinco etapas: a) observação etnográfica da região e registro fotográfico; b) entrevistas abertas; c) grupos focais com moradores; d) coleta de dados secundários; e) análise dos dados coletados a partir de triangulação e de análise temática.

Os resultados indicaram que o processo de ocupação abrupta e clandestina do lugar ocorreu entre o final da década de 1980 e início de 1990, em pleno vigor da legislação regulamentadora e em conivência com os poderes públicos estabelecidos, a despeito de todos os movimentos contrários à ocupação que emergiram; ações de educação ambiental vêm ocorrendo na área, com fragilidades que vão da proposta à concretização das ações, destacando-se significativamente a falta de envolvimento da população, na região como um todo.

Entretanto, dentre as formas de enfrentamento da problemática ambiental, o movimento de associativismo civil existente na região vem provando que é possível construir o espaço local de forma sustentável, com mais saúde e maior qualidade de vida, a partir de relações de solidariedade e de uma participação social efetiva nas discussões de implementação de políticas para as questões socioambientais, especialmente no que se refere à temática da água. A organização comunitária ACHAVE vem trazendo para o debate ambiental questões criativas e provocadoras sobre diversos temas relevantes para o enfrentamento da crise socioambiental.

Descritores: Sociologia ambiental; ambiente; movimento ambientalista; educação ambiental; Cratera da Colônia. 


\begin{abstract}
PALOS CMC. Voices of Crater: socio-environmental representations and practices in the urban scenario. São Paulo; 2004. [Doctoral Thesis - Faculty of Public Health of the University of São Paulo].
\end{abstract}

Since the beginning of this century the environmental controversy has been globally strengthen. Facing the big urban centers' environmental problems is a challenge for the politicians as well as for the civil society groups and organizations. Innovative forms to manage environmental problems have appeared from civil society movements, also called civilian associations, community organizations and social movements.

The inspiration for this work is around the dialog between the environment sociology and other sciences. Its main objective was to comprehend and analyze, taking into account the representations and practices of men and women inhabitants of the Cratera da Colonia environmental preservation area, environmental problems within an area known as a Condominio Vargem Grande, an illegal urban occupation located in the Parelheiros' sub-district in the city of São Paulo, Brazil.

The methodological approach used in this study was qualitative and five different stages were necessary to assure the depth and the quality of the analysis: a) ethnographic observation and photographic expeditions; b) individual open interviews carried out with residents' women and men; c) focus groups with residents' women and men; d) gathering of secondary data; e) thematic analyze and data triangulation.

Results showed that the process of abrupt occupation in the region took place between 1980 and 1990, during the most vital period of environmental legislation creation. This process took place in connivance with the established public power in spite of the strong opposed movements to the occupation of the regions. Related to the environmental education actions that have been taking place in the area, this work shows a number of fragilities including theoretical approaches and actions, allowing a massive lack of community participation. Regarding the way community faces environmental problems in the area, it is remarkable to observe that community has showed that is possible to build a sustainable and healthier environment with better quality of life, basing their actions in solidarity, and effective participation in the discussion and implementation of environmental politics, especially water management. The community organization called ACHAVE has brought creative and provocative issues considering relevant themes that can contribute to better understand the social -environmental crises.

Key-words: Environmental sociology, community involvment in environmental issues, environmental education, Cratera da Colonia. 


\section{ÍNDICE}

PREFÁCIO

APRESENTAÇÃO

CAPÍtUlO 1 - O PROBLEMA DA PESQUISA E O QUADRO TEÓRICO.. 11

1.1. A questão ambiental na sociedade contemporânea.................. 12

1.2. Alternativas para a saída da crise ambiental.......................... 20

1.3. O advento da sociologia ambiental.......................................... 25

1.3.1. As correntes na sociologia ambiental.......................... 28

1.3.2. A construção de uma sociologia ambiental brasileira...... 29

1.3.3. Tendência dos estudos ambientais a partir da sociologia ambiental........................................................................ $\quad 30$

1.3.4. A discussão sobre a questão do risco.......................... 32

1.3.5. O construcionismo social: a construção social dos problemas ambientais......................................................... 35

1.4. O papel dos novos movimentos sociais: a construção social dos problemas de saúde e socioambientais.............................. 40

1.5. Dos conceitos de representação, de sentidos e significados....... 45

1.6. Trocando olhares: os aportes multidisciplinares na compreensão da problemática socioambiental....................... 50

\section{CAPÍtUlO 2 - O PROCESSO dE URBANIZAÇÃo E O AMBIENTE: RISCOS À SAÚdE}

2.1. O processo de urbanização e a problemática socioambiental ...

2.2. Segregação urbana e os espaços de pobreza: os loteamentos irregulares na cidade de São Paulo 
2.3. Os mananciais da Região Metropolitana de São Paulo e a legislação............................................................................. 69

2.4. Unidades de Conservação..................................................... 71

2.5. Áreas de Proteção Ambiental e a criação da APA-CapivariMonos

3.1. Percorrendo o caminho da problemática socioambiental na Cratera da Colônia.

3.2. O itinerário de campo......................................................... 82

3.3. A pesquisa exploratória............................................... 83

3.4. Observação etnográfica e o registro fotográfico..................... 84

3.5. Entrevistas.................................................................... 86

3.6. Grupos focais........................................................... 88

3.7. Pesquisa documental....................................................... 88

3.8. Análise dos dados: análise de conteúdos das falas, dos materiais e triangulação.

\section{CAPÍTULO 4 - O LUGAR DA PESQUISA................................................}

4.1. "Cratera da Colônia": exemplo concreto de transformações socioambientais.

4.2. Caracterização socioambiental.............................................. 97

4.3. Parelheiros em dados..................................................... 102

4.3.1. Caracterização geral................................................... 102

4.3.2. Demografia............................................................ 102

4.3.3. Saúde.......................................... 105

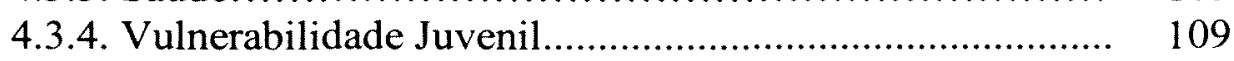

4.3.5. Educação e Renda .................................. 111

4.3.6. Cultura e Lazer ....................................................... 112

4.4. Aspectos políticos-administrativos..................................... 112

4.5. Outras entidades organizadas na Cratera da Colônia................ 114

4.5.1. Radio Comunitária ACHAVE...................................... 114

4.5.2. AMUVE - Associação de Mulheres de Vargem Grande. 115

CAPÍTULO 5 - RESULTADOS E DISCUSSÃO................................... 117

5.1. Resultados das entrevistas............................................. 120

5.1.1. Perfil do grupo de entrevistados e entrevistadas............ 120

5.2. Relatos sobre a história de ocupação da "Cratera da Colônia": Do movimento inicial para a compra da gleba até o início da ocupação.

5.3. Do início da ocupação à autoconstrução dos equipamentos básicos........................................................................... 123

5.4. Conhecimento prévio sobre a área escolhida....................... 132 
5.5. Início dos conflitos na gestão da Associação: Da UNIFAG a ACHAVE ............................................. 135

5.6. O processo de autoconstrução da moradia popular.................. 136

5.7. Relatos sobre aproximação com a questão ambiental.............. 141

5.8. Participação e ambiente: as diferentes formas de associativismo na Cratera.

5.9. Ações de educação ambiental implementadas na Cratera da Colônia.

5.10 As representações, sentidos e significados da questão ambiental para a população da Cratera da Colônia.

5.11. Comparando os grupos quanto ao gênero.

5.12. Os Problemas ambientais na Cratera da Colônia..................... 165

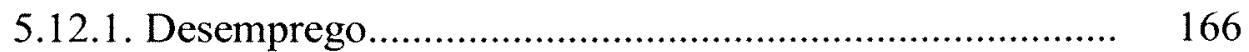

5.12.2. A violência........................................................... 168

5.12.3. A poluição das águas.................................................. 170

5.12.4. Alcoolismo e drogadição............................................ 171

5.12.5. Serviços de saúde................................................... 172

5.12.6. Desmatamento..................................................... 172

5.12.7. Saneamento básico................................................ 174

5.12.8. Pavimentação......................................................... 176

5.12.9. Lixo....................................................................... 177

5.13. Formas de enfrentamento dos problemas ambientais: soluções e responsabilidade.

\section{CAPÍTULO 6 - ENTRE O LOCAL E O GLOBAL: O ESPAÇO DA CONSTRUÇÃO DA CIDADANIA}

6.1. A emergência da dimensão comunitária e cotidiana e as transformações no "mundo da vida" de homens e mulheres ....

6.2. O papel da educação ambiental como busca de solução para os problemas socioambientais na Cratera da Colônia.

CONSIDERAÇÕES GERAIS

POSFÁCIO.

REFERÊNCIAS

\section{ANEXOS}

ANEXO 1 - Termo de Consentimento

ANEXO 2 - Roteiro da Entrevista 


\section{LISTA DE TABELAS}

TABELA 1 Densidade demográfica no Município de São Paulo (hab/ha) e na região da Subprefeitura de Parelheiros, Distrito de Parelheiros e Marsilac, em 2000

TABELA 2 População Total e Taxa Anual de Crescimento Populacional, no Município de São Paulo e Subprefeituras de Vila Mariana, Pinheiros, Parelheiros e Cidade Tiradentes, no periodo de 1991-2004

TABELA 3 População total, por grupos de idade, no Município de São Paulo e Subprefeituras de Vila Mariana, Pinheiros, Parelheiros e Cidade Tiradentes, em 2004, em números absolutos.

TABELA 4 Taxa de Mortalidade Infantil, Neonatal e Pós-Neonatal, por mil nascidos vivos, no Município de São Paulo e nas Subprefeituras de Vila Mariana, Pinheiros, Parelheiros e Cidade Tiradentes, em 1995-2003.

TABELA 5 Distribuição dos óbitos de homens e mulheres, por capítulos da CID*, no Município de São Paulo e Subprefeituras de Vila Mariana, Pinheiros, Parelheiros e Cidade Tiradentes no Triênio 2000/2002, em porcentagem.

TABELA 6 Taxas de mortalidade de homens e mulheres, por $100 \mathrm{mil}$ habitantes, por causas externas, no Município de São Paulo Subprefeituras de Vila Mariana, Pinheiros, Parelheiros e Cidade Tiradentes no Triênio 2000/2002

TABELA 7 Taxas de Analfabetismo da População de 15 Anos e Mais, por Sexo e Raça/Cor, no Município de São Paulo e nas Subprefeituras de Vila Mariana, Pinheiros, Parelheiros e Cidade Tiradentes em 2000, em porcentagem.

TABELA 8 Taxas Líquidas de Escolarização, por Níveis/Modalidade de Ensino, segundo Subprefeituras do Município de São Paulo (MSP), em 2000.

TABELA 9 Distribuição dos Domicílios, por Faixas de Renda Familiar, no Município de São Paulo e nas Subprefeituras de Vila Mariana, Pinheiros, Parelheiros e Cidade Tiradentes, em 2000, em porcentagem.

TABELA 10 Equipamentos Culturais, por Tipo, no Município de São Paulo e nas Subprefeituras de Vila Mariana, Pinheiros, Parelheiros e Cidade Tiradentes, em 2002 


\section{LISTA DE FIGURAS}

FIGURA 1 Estrutura Circular da Cratera da Colônia. Imagem obtida através do Satélite Landsat............................................... $\quad 92$

FIGURA 2 Trajetória do corpo celeste(a)............................................. 94

FIGURA 3 Momento do impacto (b) ................................................. 94

FIGURA 4 O local do impacto, mil anos depois (c)............................... 94

FIGURA 5 Localização atual da suposta cratera em Chicxulub, México (d). 94

FIGURA 6 Cratera Barringer ou do Meteoro, Arizona (EUA)................. 95

FIGURA 7 Cratera de Ries, Nordlingen (Alemanha) ............................ 95

FIGURA 8 Astroblema no Brasil. Fonte da Figura: C Riccomini............ 95

FIGURA 9 Vista aérea do Condomínio Habit. Vargem Grande. Foto cedida por: ACHAVE........................................................... 97

FIGURA 10 Vista aérea do Presídio Estadual de Parelheiros. Foto cedida por: ACHAVE........................................................................

FIGURA 11 Proporção de domicílios particulares permanentes, com forma de abastecimento de água não recomendáveis sanitariamente, segundo distrito do Município de São Paulo, 2000.

FIGURA 12 Proporção de domicílios particulares permanentes, com forma de esgotos sanitários nocivas, segundo distrito do Municipio de São Paulo, SP, 2000

FIGURA 13 Proporção de domicílios particulares permanentes, com forma de destinação do lixo nocivas, segundo distrito do Município de São Paulo, SP, 2000

FIGURA 14 Uso de Solo, Parelheiros, 2004.

FIGURA 15 Taxa de Mortalidade Infantil, segundo Subprefeituras do Município de São Paulo, no período de 1995 - 2003.

FIGURA 16 Grupos de Vulnerabilidade Juvenil, segundo Distritos do Município de São Paulo, SP, 2000. 
FIGURA 17 Posse da Diretoria da ACHAVE em Março de 2004 com a presença do Governador do Estado de São Paulo Sr. Geraldo Alckmin

FIGURA 18 Sede da Associação de Mulheres de Vargem Grande.

FIGURA 19 Construção do calçamento ecológico pelos moradores do Condomínio Vargem Grande.

FIGURA 20 Construção da Escola Fundamental do Condomínio Vargem Grande pelos moradores.

FIGURA 21 Construção do Posto da Polícia Militar pelos moradores do Condomínio Vargem Grande.

FIGURA 22 Processo de auto-construção da casa própria

FIGURA 23 Participação dos moradores da Cratera no "Dia Mundial da Limpeza" nas margens da Represa Billings.

FIGURA 24 Oficinas de Educação Ambiental e Reciclagem, promovidas pela ACHAVE.

FIGURA 25 Flores confeccionadas na Oficina de Reciclagem promovida pela AMUVE.

FIGURA 26 Construção da horta comunitária.

FIGURA 27 Mutirão do lixo organizado pela ACHAVE.

FIGURA 28 Limpeza do esgoto na área do Presídio Estadual de Parelheiros.......

FIGURA 29 Oficina de panificação implementada pela ACHAVE.

FIGURA 30 Capacitação de monitores pela SOS Mata Atlântica.

FIGURA 31 Lançamento de esgoto a céu aberto dentro do Condominio Vargem Grande. 
RELAÇÃO DAS SIGLAS UTILIZADAS

\begin{tabular}{|c|c|}
\hline SIGLA & Nomeclatura \\
\hline ACHAVE & Associação Comunitária Habitacional Vargem Grande \\
\hline AMUVE & Associação de Mulheres de Vargem Grande \\
\hline APA & Área de Proteção Ambiental \\
\hline APRM & Área de Proteção e Recuperação dos Mananciais \\
\hline CETESB & Companhia de Tecnologia de Saneamento Ambiental \\
\hline CONDEPHAAT & $\begin{array}{l}\text { Conselho do Desenvolvimento do Patrimônio - Conselho de } \\
\text { Defesa do Patrimônio Histórico, Arqueológico, Artístico e } \\
\text { Turístico do Estado de São Paulo }\end{array}$ \\
\hline CMMAD & Comissão Mundial sobre Meio Ambiente e Desenvolvimento \\
\hline CNUMAD & $\begin{array}{l}\text { Conselho das Nações Unidas para o Meio Ambiente e } \\
\text { Desenvolvimento }\end{array}$ \\
\hline CNUAH & $\begin{array}{l}\text { Centro das Nações Unidas para Assentamentos Humanos } \\
\text { (HABITAT) }\end{array}$ \\
\hline DEAPLA & Departamento de Educação Ambiental e Planejamento \\
\hline EMBRAPA & Empresa Brasileira de Pesquisa Agropecuária \\
\hline FAPESP & Fundação de Amparo à Pesquisa do Estado de São Paulo \\
\hline HABITAT & Ver CNUAH \\
\hline IBDF & Instituto Brasileiro de Desenvolvimento Florestal \\
\hline IBGE & Instituto Brasileiro de Geografia e Estatística \\
\hline ISA & Instituto Sócio-Ambiental \\
\hline LPM & Lei de Proteção aos Mananciais \\
\hline ONG & Organização-Não-Governamental \\
\hline
\end{tabular}




\begin{tabular}{|l|l|}
\hline OMS & Organização Mundial da Saúde \\
\hline OPS & Organização Panamericana da Saúde \\
\hline PSF & Programa de Saúde da Família \\
\hline SABESP & Região Metropolitana de São Paulo \\
\hline SNUC & Saneamento Básico do Estado de São Paulo \\
\hline SUS & Sistema Único de Saúde \\
\hline SVMA & Secretaria Municipal do Verde e do Meio Ambiente de São Paulo \\
\hline UICN & União Internacional de Conservação da Natureza \\
\hline UNCED & $\begin{array}{l}\text { Conferência de Cúpula das Nações Unidas sobre o Meio } \\
\text { Ambiente e Desenvolvimento }\end{array}$ \\
\hline UNIFAG & União das Favelas da Microregião do Grajaú \\
\hline UNISA & Universidade Santo Amaro \\
\hline USP & Universidade de São Paulo \\
\hline
\end{tabular}




\title{
A FANTÁSTICA CRATERA dA COLÔNIA
}

\author{
(Valdeck de Garanhuns)
}

\author{
Essa Colônia Paulista \\ É um lugar interessante \\ E eu vou contar agora \\ Um caso tão fascinante \\ Que o amigo vai ficar \\ Querendo ver num instante
}

Eu que sou um viajante Conheço o Brasil legal

O Sertão e o Agreste

A Mata e o Litoral

Já vi coisas curiosas

Mas nunca vi nada igual

O caso é fenomenal

Não está nos nossos planos Se acontecesse hoje em dia Destruinia os humanos É um buraco tão grande Com uns três milhöes de anos

Os poderes soberanos É o que pode nos livrar Por isso que à Natureza Nós devemos respeitar Pedir luz à Jesus Cristo Ser muito humilde e orar

Não precisa se assustar Mas prepare o coração Sabe o que é um meteoro? Vou the dizer meu irmão É uma bola de fogo Que desce da imensidão

\section{E vá prestando atenção} Que em linguagem popular O que seja um meteoro Eu vou tentar explicar É uma pedra do céu Que cai em qualquer lugar

Procure pro céu olhar Mas não fique muito aflito Já viu estrela cadente Que corre no céu bonito? Porém não é meteoro É só um meteorito
Imagine o infinito

Os astros celestiais

O sol, a lua, as estrelas

Planetas e muito mais

Trilhões e trilhões de coisas

Nos espaços siderais

\section{Segredos Celestiais Universo em seguimento \\ Meteoros grandes pedras \\ Em constante movimento \\ Correndo em velocidade \\ Voando no firmamento}

Eu vou dando um seguimento

A história que não erra Pois um meteoro desses Caiu aqui nessa terra Com sua força sinistra Muito pior que a guerra

Realmente foi na terra Caiu com força voraz Acertou bem na Colônia Com pontaria eficaz Isso aconteceu a três Milhões de anos atrás

Como tantos anos faz Hoje só resta a Cratera Coberta de imenso pântano Onde reside uma fera Que aparece à meia noite Denominada Quimera

Meu amigo essa Quimera É nossa imaginação Mas vá lá pra você ver Da Cratera a imensidão Dez quilômetros de diâmetro É quase a sua extensão

Além disso o buracão Tem outra realidade São quase quinhentos metros A sua profundidade Fora três milhões de anos Que ele tem de idade
Se um dessa qualidade Caisse aqui hoje em dia A Capela do Socorro Quase desaparecia Colônia virava pó E Parelheiros sumia

Meu amigo tire um dia Vá na Vargem Grande olhar Essa cratera fantástica Pra você se alegrar Das coisas que a natureza Faz pra gente admirar

Aproveito pra falar Ao governo brasileiro Que se implantar turismo $\mathrm{Na}$ cratera bem ligeiro Colônia vai ser sucesso Aqui e no mundo inteiro

Um turismo pioneiro Que ajude a população Fomente muita pesquisa Pras escolas da nação Que aquilo é ciência viva Cultura e educação

Mas lá já tem invasão Muita gente aglomerada E aquilo é uma relíquia Que deve ser presenada Principalmente que foi Pela natureza marcada

Portanto não dêem mancada Se não um dia já era Que aquele buraco grande Aonde mora a Quimera É pura realidade Quem pensar que é inverdade Vá lá e veja a Cratera. 


\section{PREFÁCIO}

"O mais importante e bonito, do mundo, é isto: que as pessoas não estão sempre iguais, ainda não foram terminadas - mas que elas vão sempre mudando. Afinam ou desafinam. Verdade maior. É o que a vida me ensinou. Isso me alegra, montão". (Rosa 1986, p.21).

Esta tese de doutorado não é um produto final. É parte de um processo cuja construção mostrou-me, claramente, que não são só os sujeitos de minha pesquisa (as mulheres e os homens da Cratera) que estão se transformando; eu também como pesquisadora, como ser humano e como mulher, no decorrer da pesquisa, me percebi em absoluta transformação, desconstruindo e reconstruindo representações das questões socioambientais, feministas e outras. Em outras palavras, pesquisadora, entrevistados e entrevistadas são, simultaneamente, sujeitos e objetos no processo de elaboração de um conhecimento, que não se restringe somente à construção de um conhecimento formal cognitivo sobre o tema trabalhado e à metodologia empregada, mas também se refere à construção de saberes permeados, sobretudo, por emoções, desejos, frustrações e sonhos.

Nasci na pequena Pirapó, cidade situado ao norte do Estado do Paraná que, de tão pequena, até já saiu do mapa. Hoje é apenas um distrito do município de Apucarana. Da minha cidade natal lembro-me especialmente da época da colheita do café: enquanto os adultos colhiam o fruto nós, as crianças, brincávamos por entre os cafeeiros. O que mais me marcou dessas reminiscências de criança foi a relação, quase simbiótica, que se estabelecia entre mim e o mundo natural. Dentro do egocentrismo natural da idade, eu era natureza e a natureza era eu.

Ainda muito pequena, mudamos-nos para uma fazenda que ficava em Tarumã, pequeno distrito da cidade de Assis, já no estado de São Paulo. Passei grande parte da minha primeira infância brincando por entre as árvores, tomando banho de rio, colhendo fruta madura no pé, ajudando na cultura de uma horta de onde vinham alguns produtos para a nossa subsistência. Da fazenda onde vivia podia 
observar, bem ao longe, outras propriedades, e passava horas e horas imaginando como seria a vida fora dali. As únicas oportunidades de conhecer outras pessoas e, especialmente, outras crianças, eram quando acompanhava a minha avó nas rezas que havia nas fazendas vizinhas, e quando tínhamos que ir até a cidade mais próxima beneficiar produtos agrícolas que produzíamos. Eram momentos mágicos para mim. Nas rezas, nunca prestava atenção ao que o padre ou as rezadeiras rezavam, pois estava sempre muito mais atenta ao comportamento, aos costumes e ao jeito das outras pessoas, em especial das outras crianças. Tinha muita curiosidade em conhecer e descobrir outras coisas fora do circuito familiar: como as pessoas viviam, o que faziam, os "causos" que contavam, enfim, penso que meu lado socióloga já se prenunciava, naquela época.

O dia de ir a cidade, então, era uma grande festa. Meus primos e eu brigávamos para ver quem acompanhava o tio na carroça. $\mathrm{Na}$ cidade, enquanto esperávamos pelos serviços, que sempre eram muito demorados, aproveitávamos para passear no vilarejo, olhar as lojas de produtos agrícolas e visitar algum compadre ou comadre de meu tio. Ao final do dia, pegávamos os produtos já beneficiados e trilhávamos o caminho de volta, que sempre era muito demorado e permeado por muitos perigos. Muitas vezes nos deparávamos com touros e vacas bravas, buracos causados pela erosão do solo, jaguatiricas ou macacos desgarrados do grupo, enfim, estes eram os perigos que enfrentávamos!

Nossa vida na fazenda era uma vida muito simples, tal como aquela relatada por Antonio Cândido em seu livro "Os Parceiros do Rio Bonito". Comíamos o que criávamos e o que plantávamos e o excedente era vendido para outras propriedades. Energia elétrica não havia, portanto, "dormíamos com as galinhas" depois das prosas noturnas. Minha avó adorava contar os seus "causos" de assombração, mula-semcabeça, saci-pererê e outros mistérios. Da minha lembrança de menina, o que mais se aproxima, para efeito de comparação, é a vida retratada por Monteiro Lobato no Sítio do Picapau Amarelo.

Com a chegada do rádio, no lugar que viviamos, as coisas passaram a ter uma outra conotação. A minha família passou a se interessar pelas noticias que chegavam de São Paulo e do Rio de Janeiro, o que causava grande encantamento, 
principalmente em minha avó com a possibilidade de largar aquela vida "dura" no campo e tentar uma vida mais "fácil" na cidade, especialmente, como operários da grande indústria promovida nos anos $\mathrm{JK}^{\prime}$.

E foi assim que, acalentados por esse sonho, minha família se desfaz de tudo que havia construido no campo e muda-se para São Paulo. Na minha lembrança de menina, foi um grande choque: inicialmente fomos morar num cortiço no Bairro da Barra Funda, na Rua Quirino dos Santos. Como era uma área de várzea, com o agravante que, em frente da casa que morávamos, passava um córrego, quando chovia tudo virava um grande lago. As casas eram invadidas pelas águas contaminadas do córrego que em seu percurso recebia uma grande carga de dejetos lançados pelas residências e pelas indústrias locais.

Imperava a lei da seleção natural: sobreviviam os mais fortes e os mais aptos. Eu sobrevivi!

Depois de todos os componentes da família terem se empregado em grandes indústrias, conseguimos comprar a tão sonhada casa própria num bairro novo bastante distante dali: na Vila Nova Cachoeirinha. Não havia energia elétrica, nem rede de abastecimento de água, muito menos de esgotos. Para conseguir água, tínhamos que caminhar cerca de dois $\mathrm{km}$ até uma mina próxima, onde se formavam filas intermináveis. Para conseguir uma condução para o centro de São Paulo, tínhamos que caminhar até o Bairro de Vila Santa Maria, que ficava a três km de distância, "era uma pernada".

Era uma vida duríssima, e apesar das pessoas perceberem e sentirem na pele os desconfortos causados pela degradação socioambiental do lugar, encaravam-na com uma passividade e resignação que me irritava profundamente. Embora a situação socioambiental se apresentasse de forma extremamente precária, aquela questão não fazia parte do rol de inquietações das pessoas, era encarada como um fato inexorável e desagradável da vida, contra o qual pouco podiam fazer.

$\mathrm{Eu}$, em plena turbulência de adolescente, não conseguia entender como as pessoas aceitavam aquela situação de degradação com tamanha naturalidade, e

\footnotetext{
'Periodo referente ao chamado "desenvolvimentismo brasileiro", no governo do Presidente Juscelino Kubitschek (1956-1961) durante o qual a industrialização foi impulsionada no país, especialmente a indústria automotiva.
} 
sentia-me revoltada com a situação. Naquela época, já conseguia estabelecer algumas conexões entre as políticas econômicas e as conseqüentes desigualdades sociais existentes em nosso país.

Hoje, já adulta e com uma considerável acumulação de experiência sobre o tema, corroboro as afirmações de Hannigan de que, por mais que as condições ambientais sejam visivelmente más, ou mesmo que sejam catastróficas, a percepção do público com relação a elas não é nada automática. A problemática ambiental necessita ser construída socialmente! Mas esta é uma história sobre a qual discutirei no decorrer da presente tese.

Retomando a minha trajetória de vida, como tive que ingressar no mercado de trabalho ainda bastante jovem, por volta dos doze anos, minha formação escolar ficou bastante prejudicada. Mas, entre "trancos e barrancos" consegui, com muito custo, terminar o curso médio, e muitos anos se passaram até que tive a oportunidade de ingressar na vida acadêmica, o que aconteceu em meados da década de 1970, já casada e com filhos. Na Pontifícia Universidade Católica de São Paulo, iniciei o curso de Economia e, mais tarde, transferi-me para o de Ciências Sociais, em meio a toda a agitação política que marcava aqueles anos.

Claro que, com toda a história de vida que carregava, e como toda cientista social fruto daquela época, minha formação acadêmica foi bastante, porque não dizer totalmente, influenciada pelo materialismo-histórico dialético. Acreditávamos que podíamos mudar o mundo. Lia Marx, Engels, Althusser, Gramsci, Rosa de Luxemburgo, criticava Dürkheim, Augusto Comte. Enfim era uma marxista de carteirinha. Participei do Movimento Estudantil. Estava lá quando invadiram a universidade.

Apesar de todas as dificuldades políticas da época, sentia-me privilegiada, pois tinha aulas com muitos professores que, no período, estavam voltando do exílio e que encontraram, na PUC, um espaço aberto para reiniciarem suas atividades, drasticamente interrompidas pelo AI-5: professor Paul Singer, que ministrava o curso de Economia Política, na graduação de Economia; professor Paulo Freire, que tanto nos comovia com sua pedagogia do oprimido; professor Otávio Ianni, com quem aprendi a admirar Gramsci; professora Maura Véras, com quem me aproximei dos 
movimentos por moradia, e muitas outras figuras que, de uma forma ou de outra, marcaram minha formação acadêmica.

Embora a minha preocupação com a questão ambiental estivesse adormecida durante o tempo da minha graduação, sendo substituída por outros interesses de "caráter social e político", terminado o meu bacharelado, fui trabalhar durante um período na CETESB - Companhia de Tecnologia e Saneamento Ambiental, onde o meu interesse pela questão ambiental voltou a se insinuar. E foi assim que a questão ambiental continuou a ser construída em minha vida. $O$ meu interesse foi tanto que iniciei, logo depois, o mestrado na Faculdade de Saúde Pública da USP, com um tema já definido: o meio ambiente.

Inseri-me na pesquisa "Educação ambiental via representações populares e acadêmicas do meio", desenvolvida em Vera Cruz e em Espírito Santo do Turvo, duas cidades do centro-oeste paulista, por um grupo de pesquisadores e pesquisadoras da Faculdade de Saúde Pública da USP, Faculdade de Educação e da Escola Superior de Agricultura Luís de Queiros, em continuidade a um outro trabalho de extensão rural denominado Projeto UNIR - uma experiência rural, financiado pela Fundação Kellogs e desenvolvido pelas mesmas escolas nos anos de 1994 a 1997.

Por razões subjetivas, e como já militava nos movimentos sociais de gênero, apaixonei-me pela idéia de trabalhar com um grupo de mulheres em Espírito Santo do Turvo, que estava desenvolvendo um projeto de geração de renda. Esse grupo já existia na cidade, mas recebeu uma injeção de ânimo proporcionada pelo Projeto UNIR. E assim concluí a minha dissertação de mestrado: Saúde e ambiente: as representações e práticas de um movimento de mulheres em Espírito Santo do Turvo-SP.

Terminado o mestrado, entrei imediatamente no doutorado, com uma idéia em mente: ampliar e aprofundar o trabalho iniciado no mestrado, porém com grupos de mulheres da cidade de São Paulo. Inicialmente comecei o trabalho de observação com vários grupos de mulheres em diferentes regiões da cidade, o que se mostrou inviável em termos de logística. Optei, então, em trabalhar com um grupo de 
mulheres do Condomínio Vargem Grande, situado na Cratera da Colônia, distrito de Parelheiros.

Porém restara um sentimento que me acompanhava o tempo todo - o da insatisfação com um único referencial teórico com o qual vinha trabalhando, qual seja, o das representações sociais. Já no mestrado, tal referencial havia se mostrado insuficiente para, isoladamente, abarcar toda a riqueza e a complexidade do tema. Agora no doutorado, minhas interrogações vinham se confirmando: toda a complexidade do tema, toda a riqueza da experiência e a grandeza do campo exigiam o aporte de outras áreas da ciência. A necessidade de um redirecionamento teórico e metodológico tornou-se inevitável.

Daí até redefinir o referencial teórico e a metodologia foi um árduo caminho. Às vezes com interlocutores entusiasmados, outras vezes nem tanto, mas com um objetivo em mente: construir um desenho de pesquisa que atendesse não só às exigências acadêmicas, mas também que fizesse sentido para a minha vida, e pudesse, ainda, acenar para melhorias das condições socioambientais vividas pelas populações locais.

Partindo do pressuposto de que, no interior de campos de conhecimento, desenham-se formas de representar e falar sobre a problemática socioambiental, e que essas formas são específicas a certas tradições cognitivas e emotivas sobre o ambiente, esta investigação se insere num esforço por abordar a questão socioambiental por meio de um estudo das representações, sentidos, significados e práticas da questão socioambiental no cenário urbano, partindo de uma abordagem da sociologia ambiental. Interessava-me captar não só os aspectos cognitivos da construção da problemática socioambiental local, mas também as outras dimensões que determinam as representações dos sujeitos na vida social, isto é, tanto aspectos subjetivos como aspectos macroestruturais.

Uma preocupação me impulsionava: a necessidade de desenvolver novos enfoques de análise para uma questão amplamente estudada, no caso, a problemática socioambiental e, ao mesmo tempo, contribuir para a compreensão das construções e modalidades específicas que assumia a problemática socioambiental, de acordo com o posicionamento de diversos atores na rede de relações que sustentam a discussão e 
os conflitos na área conhecida como Cratera da Colônia. A partir do trabalho desenvolvido na Cratera da Colônia, me interessava destacar o papel das pessoas situadas em contextos locais, na construção de suas explicações; e interessava-me olhar para as estruturas locais de saber e para os processos de comunicação e de conflitos que as pessoas estabelecem, a partir de determinadas posições, na construção de suas vidas cotidianas.

Tal como GARCIA (2004), busco com esta pesquisa, contribuir com a produção de investigações reflexivas e comprometidas com as pessoas com as quais venho trabalhando. Para tanto, neste trabalho não pretendo produzir generalizações abstratas sobre como os fenômenos sociais devam ser abordados, e sim contribuir para a compreensão desses fenômenos partindo da problemática local de interesse para as pessoas envolvidas, e na busca de soluções para seus problemas. Dessa maneira, sinto que posso resgatar aquele sonho de adolescente: contribuir para a diminuição das desigualdades sociais e, conseqüentemente, contribuir para a construção de uma vida mais digna às populações menos privilegiadas.

Por outro lado, um princípio ético norteava o meu objetivo, o que me fez buscar partilhar algo com os sujeitos locais envolvidos na investigação: eu estava ali para observar, pesquisar e elaborar a minha tese de doutorado e, como contrapartida doaria um dia semanal do meu trabalho para a comunidade, da maneira que eles julgassem mais necessária. Inspirada no preceito do "intelectual orgânico" de Gramsci, estava imbuída do conceito do papel transformador da educação. Neste afã, foi então que nasceu a proposta inicial de construção de uma Agenda 21 das Mulheres da Cratera da Colônia. Mas esta é uma outra história, que necessita do desenvolvimento de uma outra tese.

E foi assim que fui me apropriando do lugar, com todas as minhas representações, idéias e sonhos. Caminhei pelas ruas do lugar, conheci muitas pessoas, conversei com elas sobre a problemática local, tomei inúmeros cafés com bolinhos nas casas de minhas interlocutoras e de meus interlocutores, onde sempre era recebida com muito carinho. Em resumo, comecei propriamente minha pesquisa por meio de uma observação etnográfica, para a qual me apoiei nos aportes da antropologia, especialmente em Geertz. O caminho para a Cratera era longo: até 
concluir a pesquisa foram diversas viagens, porque realmente é uma viagem pois, partindo de minha casa para chegar até a Cratera, tinha de percorrer mais de $100 \mathrm{~km}$ entre ida e volta.

Quando reconhecemos a existência de um vínculo contínuo e crescente, existente entre saúde pública, problemas socioambientais, condições de vida e urbanização, segundo os argumentos até aqui explicitados; quando trabalhamos com a produção de pesquisas reflexivas de fenômenos locais e, sobretudo, com pesquisas comprometidas ou engajadas com interesses e necessidades das comunidades, acreditamos que estamos contribuindo para a preservação e a criação de ambientes saudáveis, para a promoção da saúde e para a busca conjunta de soluções para os problemas locais.

Partindo também do pressuposto de que o conhecimento que construímos é sempre parcial e provisório, este trabalho, realizado na Cratera da Colônia, é resultante da interação de minhas visões de mundo e das visões dos vários interlocutores que participaram desta investigação, porém, não há a pretensão de estabelecer generalizações e comparações com outros fenômenos; contudo, em muitos pontos da construção da tese procurei estabelecer algumas conexões e interfaces com outros fenômenos estudados, a título de buscar interpretações que contribuíssem ao melhor equacionamento dos problemas vividos na localidade.

Outros pontos que nortearam o desenvolvimento da presente tese foram: o entendimento de que a gravidade e importância da questão socioambiental, sua centralidade e complexidade, suas amplas repercussões sobre a vida no planeta em suas diversas interfaces exige, para o enfrentamento dessa questão, no âmbito das ciências e no âmbito das ações implementadas pelo Estado para solucionar tais problemas, a transcendência de perspectivas unilaterais e a busca uma efetiva interdisciplinaridade e transdiciplinaridade; e a constatação de que as soluções para a problemática socioambiental requerem, além de ações realizadas sob uma perspectiva macroestrutural, ações localizadas que contemplem a subjetividade dos sujeitos.

Finalmente, cabe ressaltar que a escolha da área estudada deveu-se também ao fato de que, embora se trate de uma região que, do ponto de vista de suas reservas 
hidrográficas, tenha sido objeto de interesse e regulamentação por parte do poder público, do ponto de vista da produção de conhecimentos científicos a partir de uma abordagem das Ciências Sociais, e mais especificamente, da Sociologia Ambiental, poucos estudos têm sido desenvolvidos, especialmente levando-se em conta a relevância da complexidade socioambiental singular da "Cratera da Colônia", a qual abriga um conjunto de realidades físico-biótico-antrópicas que sintetizam vários processos e impasses ecológicos e socioambientais brasileiros.

O lugar da pesquisa refere-se a um processo de ocupação clandestina de uma área de estrutura geológica circular, existente no município de São Paulo, Brasil, conhecida popularmente como Cratera da Colônia e, nos meios científicos, como “Astroblema da Colônia". O esforço concretizado nos capítulos a seguir é decorrente do meu empenho, no sentido de buscar compreender o estabelecimento e construção de uma problemática socioambiental, a partir das vozes dos moradores e das lideranças comunitárias do Condomínio Vargem Grande, loteamento inserido dentro da Área de Proteção Ambiental APA - Capivari-Monos, no extremo sul da cidade de São Paulo; em muitas passagens desta tese esses habitantes foram denominados de "os moradores da Cratera".

Essa comunidade vive na Cratera da Colônia as agruras do cotidiano, em uma região marcada por problemas oriundos de uma ocupação predatória, fruto da grande especulação imobiliária presente na cidade, combinada à presença reduzida, inexistente ou dúbia do Estado, uma ocupação conquistada, como direito social, em resultado dos movimentos organizados pela população em torno da construção social dos problemas de moradia, do ambiente, de saúde.

A pesquisa iniciou-se em 2002 e se estendeu até o fim de 2004, período curtíssimo para uma pesquisadora pretensiosa, que acreditava ser esse tempo suficiente para realizar todos os seus sonhos. Certamente não o foi. Porém, ficou uma certeza, uma das poucas na imensidão de dúvidas que restaram: ainda que não tenha conseguido concretizar todas as propostas iniciais, valeu pelo processo de aprendizagem, bastante significativo, para minha carreira como pesquisadora e para minha vida pessoal. Espero especialmente, que esta tese contribua para melhorar as condições socioambientais vividas pela população da Cratera da Colônia. 


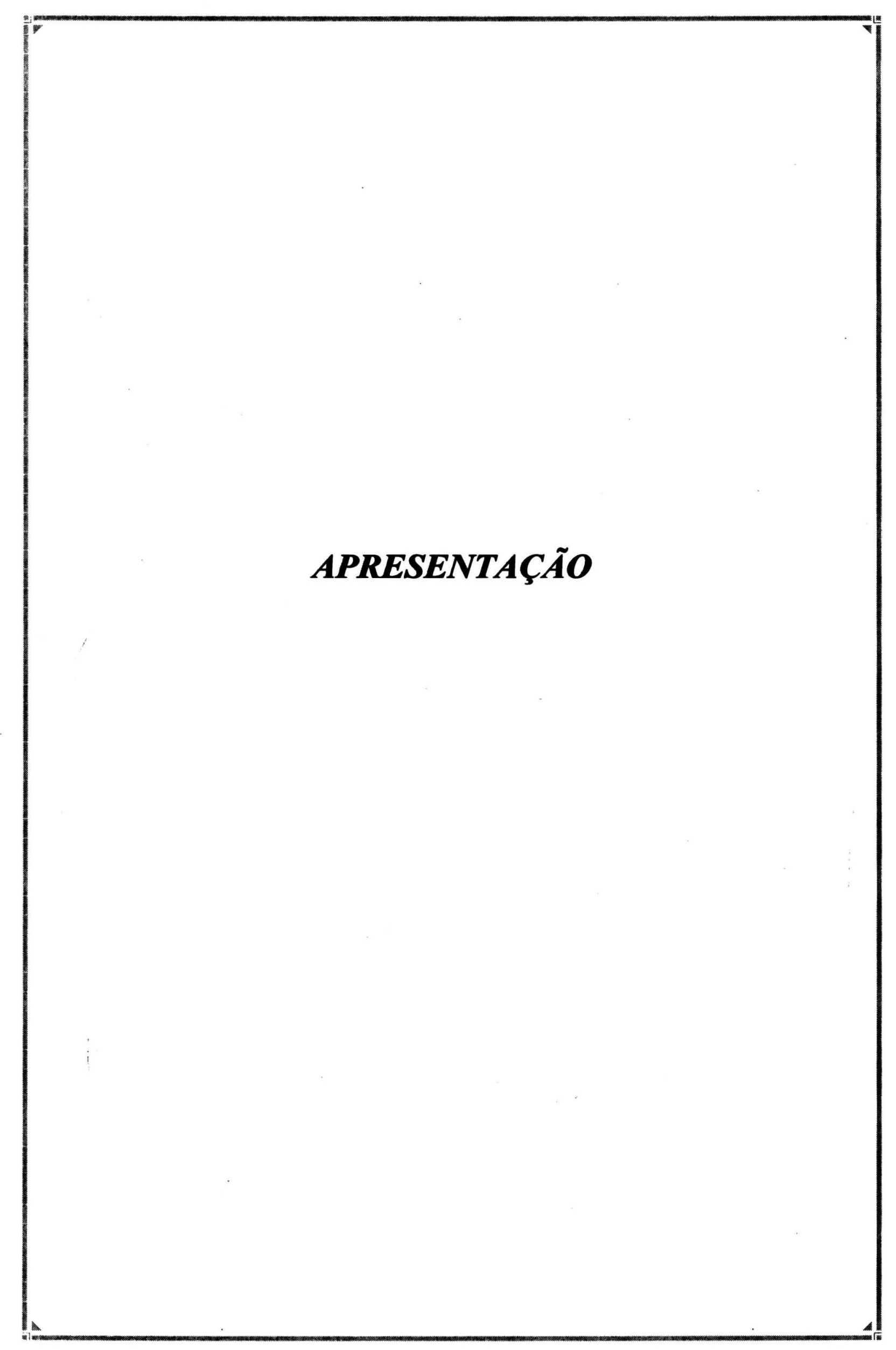


Passados mais de dez anos desde a realização da Conferência Mundial das Nações Unidas sobre o Meio Ambiente e o Desenvolvimento, a ECO-92, a situação ambiental em que o planeta se encontra reveste-se de uma gravidade ainda maior que aquela detectada na ocasião, conforme indicado em sucessivos relatórios de instituições internacionais. Grande parte das metas e planos de ação elencados para enfrentar problemas decorrentes da poluição, dos desmatamentos, da dependência de combustiveis fósseis, da desertificação e dos lançamentos de resíduos no ambiente ainda não foi implementada.

Antes da questão ambiental aparecer em cena com a força e a importância que alcançou nos primeiros anos do Século XXI, já faziam parte, da agenda de planejadores urbanos e autoridades municipais, os problemas relativos ao ambiente. O debate sobre o tema, porém, é relativamente recente e, na América Latina, deve-se, em grande parte, à Conferência ECO-92, na qual organismos governamentais, comunidade acadêmico-científica e organizações-não-governamentais de todo o mundo debruçaram-se sobre o tema.

Autores de diversas áreas do conhecimento vêm apontando a intensificação de problemas socioambientais globais como uma das principais características das sociedades contemporâneas. Destruição da camada de ozônio; poluição do ar, das águas e do solo; desertificação; salinização; erosão; riscos de acidentes nucleares ou tecnológicos; aquecimento global; disposição inadequada de resíduos sólidos; drenagem urbana insuficiente; destruição das florestas tropicais, todos estes problemas têm representado fortes ameaças à nova ordem mundial, à saúde humana $\mathrm{e}$ à vida no planeta (VIOLA 1996; SOBRAL 1997; SANTOS BS 1995; HANNIGAN 1995; LEFF 2001).

HANNIGAN (1995) menciona que a preocupação ambiental não é constante, mas flutua ao longo do tempo, aumentando e diminuindo em proeminência. Para este autor, os problemas ambientais não se materializam por si próprios: em vez disso, devem ser "construídos" pelos indivíduos ou organizações da sociedade civil em que se inserem. Baseando-se nesse conceito, pode-se dizer que a partir das grandes 
catástrofes ${ }^{2}$, ocorridas após a segunda metade do Século XX, a problemática ambiental começou a ser construída, tanto por parte do público afetado como pelos problemas, do desenvolvimento do conhecimento científico, e da atuação dos meios de comunicação social.

Para VIEIRA (2001) transcorridos mais de três décadas desde a realização da Conferência de Estocolmo (1972), a sociedade e o Estado continuam a lidar com a crise socioambiental como se ela representasse apenas uma "perturbação tempestiva", no dizer desse autor, "uma espécie de ruido de fundo a ser tratado de forma reativa e fragmentada, sem implicar a transgressão da lógica profunda que condiciona a organização das sociedades contemporâneas". Ainda para VIEIRA (2001, p.9), “...no plano das mudanças efetivas de comportamentos, a crise socioambiental constitui um item ainda marginal da agenda de preocupações da maior parte da população do planeta...".

Por um outro lado, o mundo está cada vez mais urbano. Diversas pesquisas apontam um contingente de $80 \%$ da população do planeta vivendo em cidades. Apesar de constituir-se como habitat no mundo contemporâneo, a cidade reveste-se de muitos significados, condensa diferentes facetas ligadas ao mundo econômico, à vida social, à cultura, atingindo os modos de vida, as subjetividades, a comunicação, a questão do território e da alteridade (VÉRAS 2000).

Assim como existe o lado positivo de se viver em grandes cidades, principalmente pela disponibilidade de serviços e pelo espetacular desenvolvimento material, tecnológico e produtivo, há também o lado negativo, extremamente perverso, particularmente no que se refere à dificuldade de acesso das populações mais carentes aos serviços básicos para uma vida digna: nutrição, habitação, saúde, educação, saneamento, creches, lazer, cultura, entre outros. Um dos principais problemas das sociedades contemporâneas, nos grandes centros urbanos refere-se, sem dúvida alguma, à questão da moradia e à ocupação desordenada de áreas insalubres ou de áreas não propícias ao desenvolvimento urbano.

${ }^{2}$ Os acidentes nucleares de Chernobyl e Three Mile Island, o desastre químico de Bhopal, o naufrágio dos petroleiros Torrey Canyon e Exxon Valdez foram alguns dos acontecimentos dramáticos do século $\mathrm{XX}$, que contribuíram para a identificação e para a construção social e política da questão ambiental, em âmbito mundial (HANNIGAN 1995). 
“A exclusão social tem sua expressão mais concreta na segregação espacial ou ambiental, o que vem configurando pontos de concentração de pobreza à semelhança dos guetos, ou imensas regiões nas quais a pobreza é homogeneamente disseminada. Pela primeira vez na história do pais registram-se extensas áreas de concentração de pobreza, a qual estava esparsa antes do processo de urbanização. A densidade de ocupação do solo, a exclusão social e as promessas de modernidade próximas representam uma situação inédita" (MARICATO 2001, p.217).

Grandes contingentes populacionais encontram-se excluidos do acesso a uma habitação digna, trazendo conseqüências impactantes ao ambiente natural e se expondo, na maioria dos casos, a situações de risco social e ambiental, tais como riscos de enchentes e desmoronamentos, maior exposição à violência, discriminação racial, dentre outros. A segregação ambiental é uma das faces mais importantes da exclusão social e parte ativa dela (MARICATO 2001).

Autores como SANTOS M (1997); IANNI (1996); GOTTDIENER (1993); SANTOS BS (1995) e DOWBOR (1999) corroboram, com seus estudos, a idéia de que a presente fase da globalização traz, em seu bojo, resultados bastante negativos ao desenvolvimento humano, com acentuadas disparidades, desigualdades sociais e privações de toda ordem. As exigências da reprodução ampliada do capital e de sua concentração e centralização resultam numa grande polaridade do mundo.

VÉRAS (2003), numa alusão ao paradigma das global cities ${ }^{3}$, enfatiza que as grandes cidades são uma síntese das contradições capitalistas: reúnem tanto os lados perverso e atrasado quanto o avançado dos primeiro e terceiro mundos. “... a global city reúne as caracteristicas de ser fundamento do capital financeiro ou pólo de tecnologias de ponta nas indústrias, bem como apresenta camadas sociais emergentes ligadas à gestão do capital e, também, massas de desempregados, grandes contingentes de trabalhadores informais, conflitos étnicos e outros processos" (VÉRAS 2003).

\footnotetext{
${ }^{3}$ Dentre os autores pioneiros que vem trabalhando com este conceito pode-se citar Sassen (1991). Porém, outros autores tais como: Feagin e Smith, Borja, Castells, Preteceille, Ianni e Véras também têm trabalhado a partir desta abordagem (VERAS 2003).
} 
A cidade de São Paulo, no Brasil, é um desses grandes centros urbanos, na América Latina, que apresenta as profundas contradições e desigualdades socioeconômicas e culturais que caracterizam o mundo globalizado e as chamadas global cities. Os problemas da cidade não são recentes, mas vêm se acumulando desde a época da industrialização, chegando a um ápice, no início do Século 21 , situação que vem desafiando estudiosos dos temas urbanos, ambientais e daqueles que se preocupam com a conquista e ampliação da cidadania para todos.

No texto a seguir, VÉRAS (2003) consegue sintetizar, de forma bastante pertinente, o significado de cidades como São Paulo, nesta fase de globalização.

"São Paulo concentra as polaridades das cidades mundiais, transparecendo processos contraditórios que abrangem desde as conhecidas tendências à desconcentração metropolitana, ’̀ diminuição do número de indústrias e terceirização (em especial com expansão do setor de serviços, telecomunicações $e$ informática) até crescentes exclusão e misérias sociais, aumento do desemprego, informatização e terceirização, além da configuração espacial desses processos: periferias desequipadas, crise da moradia popular (favelas, cortiços, casas precárias, homeless, condominios fechados para estratos de renda alta $e$ média e seu contraponto comercial, os shopping centers). Na desigualdade do espaço, zonas de deterioração em contraste com áreas de "renovação" urbana e distribuição diferenciada de ocorrências de chacinas, risco de violência, discriminação, além de cenários de devastação ecológica" (VÉRAS 2003, p.14).

Os impactos do crescimento urbano assistidos no início de século XXI, na cidade de São Paulo, são extremamente variados, graves e profundos. A especificidade do fenômeno, apresentada neste trabalho acadêmico, revela-se em práticas sociais de apropriação e uso do solo predatórias e contradizentes com as expectativas legais, técnicas e sociais, principalmente em áreas que guardam os 
Apresentaçào

mananciais que abastecem a cidade. No espaço de tempo em que foram desenvolvidos os estudos no campo, durante os anos de 2002 e 2004, presenciou-se um grande aumento da população que procura a região em busca da concretização do sonho da casa própria.

A cidade, como espaço de grandes contrastes, articula uma gama de lógicas, que atinge de forma diferenciada seus diversos grupos sociais, variando segundo o recorte de gênero, classe social, idade/geração, origem urbano/rural, orientação sexual, religião e étnico/racial, entre outros. E é justamente essa diversidade que favorece a articulação de diferentes formas de luta por direitos, fazendo da cidade também um espaço social de construção da cidadania (VÉRAS 2003).

Grandes contingentes populacionais procuram fugir do destino das favelas e cortiços da cidade, em busca da concretização do direito legítimo por uma moradia. Quase sempre, esses loteamentos e brechas que lhes restam no mercado imobiliário, não correspondem ao sonho de uma habitação mais digna. $O$ que resta a essa população, já tão espoliada, são pequenos espaços nas periferias da cidade, muitas vezes em regiões de risco, como áreas de encostas, áreas propensas a enchentes ou em localizações sujeitas a elevados índices de poluição, ou ainda em loteamentos clandestinos, ou em sítios não propícios ao assentamento humano, como é o caso das áreas de proteção dos mananciais. É somente nesses lugares que a parcela excluída da população tem condições de adquirir o seu lote para a construção da casa própria, geralmente edificada por eles próprios (KOWARICK 2001; MARICATO 2001; BONDUKI 1998; VÉRAS 2000, 2003).

Levando em consideração a irreversibilidade do processo de ocupação de uma área de estrutura geológica circular, existente no município de São Paulo, conhecida popularmente como Cratera da Colônia, ou como "Astroblema da Colônia" nos meios científicos, esta tese de doutoramento foi realizada com o objetivo de contribuir para o debate da problemática socioambiental que se estabelece nos grandes centros urbanos, a partir do referencial teórico da sociologia ambiental em interface com a geografia, a sociologia urbana, a psicologia social, a economia política e a antropologia. 
O esforço concretizado nas páginas a seguir é decorrente do empenho da pesquisadora, no sentido de compreender o estabelecimento e construção de uma problemática socioambiental, a partir das vozes dos moradores e das lideranças comunitárias do Condomínio Vargem Grande, loteamento clandestino inserido dentro da Área de Proteção Ambiental APA - Capivari-Monos, no extremo sul da cidade de São Paulo; em muitas passagens desta tese, esses habitantes são denominados "os moradores da Cratera".

Essa comunidade vive na Cratera da Colonia as agruras do cotidiano em uma região marcada por problemas oriundos de uma ocupação predatória, fruto da grande especulação imobiliária presente na cidade, combinada à presença reduzida, inexistente ou dúbia do Estado, uma ocupação conquistada, como direito social, em resultado dos movimentos organizados pela população em torno da construção social dos problemas de moradia, do ambiente, de saúde.

Reconhecendo-se o vínculo contínuo e crescente, existente entre saúde pública, problemas socioambientais, condições de vida e urbanização, acredita-se necessária a realização de pesquisas e projetos que propiciem o desenvolvimento e a capacitação das comunidades dos centros urbanos, no que se refere tanto à preservação e à criação de ambientes saudáveis, quanto à promoção da saúde, com o objetivo de melhorar a qualidade de vida. A partir desses pressupostos, pretende-se ainda, com este trabalho, poder contribuir efetivamente para o desenvolvimento socioambiental local.

A presente investigação tem como hipóteses: que a questão ambiental, assim como qualquer outro tema, é uma construção social e que grande parte da degradação ambiental, que ocorre na periferia da cidade de São Paulo e em outras localidades do país e do planeta, não é, senão, uma expressão concreta e perversa da exclusão social, configurada a partir do desenvolvimento de um sistema político-econômico que tem como características principais a elevada concentração de renda e riqueza, de desequilíbrios sociais, crises, desemprego, miséria e depleção do ambiente natural.

Cabe destacar que embora a degradação ambiental possa ser presenciada tanto nas áreas mais ricas como nas mais pobres, é nessas últimas que o quadro 
Apresentação

apresenta-se de forma mais grave, especialmente porque a questão é conjugada com outros indicadores sócio-econômicos extremamente insatisfatórios, como apresentarse-á mais adiante.

Outra hipótese levantada é que a população organizada em associativismos civis $^{4}$, movimentos sociais e comunitários, com suas atuações no cotidiano, suas propostas, suas diversidades de experiências, vem construindo a cidade no seu dia-adia, e vem construindo novas alternativas de sobrevivência, novos conhecimentos sobre sua realidade, estabelecendo, dessa maneira, uma "nova sensibilidade" em relação à questão ambiental; isso pode contribuir para o estabelecimento de políticas sociais mais justas e eqüitativas, o que remete à idéia de que o direito universal à cidade, a um ambiente saudável e à saúde exige uma superação da produção abstrata do espaço, por meio da concretização de uma produção social comum e articulada entre os diversos atores sociais, sejam eles poder público, setor privado, organizações não-governamentais e as populações envolvidas.

Nesse momento histórico, no qual o processo de globalização pressiona no sentido da homogeneização estética, política, cultural, atropelando direitos e diferenças, percebe-se também a emergência de um movimento inverso: de ressingularização, de afirmação de direitos, de diferenças, de localização de lutas, trazidos pelos novos movimentos sociais, como formas de resistência e na elaboração de propostas para o enfrentamento da crise que o pais e a sociedade atravessam. Fazse necessário conhecer de que modo as comunidades locais se organizam para minimizar, eliminar, ou enfrentar os problemas socioambientais de grandes centros urbanos, enfim, como essas populações estão construindo um espaço social, visto que a participação das populações vem se tornando um mecanismo cada vez mais importante para o enfrentamento das dificuldades geradas pela forma excludente de organização social, política e econômica do país.

Nesse sentido, autores das mais diversas áreas do conhecimento têm contribuído para o debate acerca da busca de soluções aos problemas detectados,

\footnotetext{
${ }^{4}$ Associações civis se constituem em formas organizadas de ações coletivas, ONGs, grupos de cooperação, contestatórios, utópicos, entre outros. Já o movimento social é uma categoria mais abrangente, que engloba as categorias de associativismo civil e de sujeito social. (SCHERERWARREN 1999).
} 
ressaltando, como SANTOS BS (1995), a importância, “....na reinvenção de um Estado moderno, das práticas e propostas de potencialização de movimentos contrahegemônicos que possam gerar um novo estado emancipatório e propiciar uma nova articulação entre politicas de igualdade e políticas de identidade" 5 ou ainda, como DOWBOR (1999) que, identificando como tendências estruturadoras do futuro, ou como eixos contraditórios, a tecnologia, a globalização, a polarização econômica, a urbanização e a transformação do trabalho, propõe que a humanidade reverta a continuidade desse processo, dotando-se de instrumentos institucionais capazes de capitalizar os avanços científicos, e mudando-os em direção a um desenvolvimento socialmente justo, economicamente viável e ambientalmente sustentável.

Para tanto, foram definidos como objetivos deste estudo:

\section{Objetivo geral}

Compreender, com o aporte da sociologia ambiental, em diálogo com outras áreas do conhecimento, o estabelecimento e a construção social de uma problemática socioambiental na Cratera da Colônia, distrito de Parelheiros, zona sul do município de São Paulo, estado de São Paulo, Brasil, a partir das vozes de moradores e lideranças comunitárias do Condomínio Vargem Grande, uma ocupação clandestina de parte da área da Cratera, ora em processo de regulamentação, com a finalidade de subsidiar as reflexões, discussões e iniciativas referentes à problemática socioambiental no Brasil, objetivando a construção de uma sociedade mais justa, eqüitativa, economicamente viável e ambientalmente sustentável.

\footnotetext{
${ }^{5}$ Um dos principais eixos da obra de Boaventura Souza Santos é a decodificação do paradigma da modernidade e os movimentos de contraposição a esse paradigma na direção da emancipação social e da felicidade dos homens e das mulheres, sem distinção de cor, raça, gênero, etnia ou condição econômica e social. Segundo este autor, construir um novo senso comum emancipatório supõe uma nova racionalidade ancorada na subjetividade individual e coletiva.
} 


\section{Objetivos especificos}

1. Elaborar uma análise socioambiental da "Cratera da Colônia", com ênfase nas ações antrópicas e nas alterações socioambientais;

2. Identificar e analisar os significados que homens e mulheres atribuem à questão ambiental na Cratera da Colônia;

3. Identificar as percepções a respeito das causas e das possíveis formas de enfrentamento da problemática socioambiental estabelecida na área;

4. Analisar avanços e retrocessos na construção de um projeto de desenvolvimento socioambiental por parte dos grupos sociais locais.

A tese está estruturada em seis capítulos, seguidos pelas considerações gerais do posfácio e pelas referências bibliográficas.

O primeiro capítulo aborda o problema da pesquisa e o referencial teórico utilizado. São discutidos os principais pontos de vista e a centralidade da questão socioambiental na sociedade contemporânea. Em seguida, apresenta-se o advento da sociologia ambiental e suas linhas de atuação, tanto em âmbito nacional como internacional. Neste capítulo também se reflete sobre o papel desempenhado pelos novos movimentos sociais na construção da problemática socioambiental. Finalizando o capitulo, apresenta-se uma discussão acerca dos aportes advindos de outras áreas da ciência para a compreensão da problemática socioambiental.

O capítulo dois trata da interrelação entre o processo de urbanização e os aspectos de ambiente e saúde que, desde o início da formação das cidades, estiveram presentes nas investigações de diversos estudiosos. Em seguida, abordam-se a conformação da cidade clandestina e os espaços de pobreza na cidade de São Paulo, que se materializam por meio de diversas maneiras e, no caso tratado nesta tese, nos loteamentos irregulares na cidade de São Paulo. Como a área delimitada para o estudo situa-se numa área de proteção aos mananciais, faz-se uma breve discussão acerca da legislação que versa sobre o tema e, na seqüência, apresenta-se uma discussão sobre Unidade de Conservação e uma das formas de gestão, que é a APA- 
Área de Preservação Ambiental. Finalizando o capítulo traz-se uma breve caracterização da APA Capivari-Monos, onde se insere a Cratera da Colônia.

$\mathrm{O}$ capitulo três refere-se às estratégias metodológicas utilizadas, acompanhadas da descrição geral das respectivas formas de abordagem. São descritos os itinerários da pesquisa, os instrumentos de coleta de dados e a formas de análise.

O capítulo quatro contempla uma caracterização do lugar da pesquisa: a Cratera da Colônia, na região de Parelheiros, São Paulo, destacando a relevância dos aspectos físico-geológicos e socioambientais.

O capítulo cinco trata dos resultados e discussão.

O capítulo seis apresenta uma discussão acerca dos temas que se sobressaíram a partir da análise temática, a saber, a emergência e a importância de uma dimensão local no que tange à discussão dos problemas socioambientais, e o papel da educação ambiental para a construção social em torno das soluções para a problemática socioambiental local. 
CAPÍTULO 1

O PROBLEMA DA PESQUISA E O QUADRO TEÓRICO 


\subsection{A questão ambiental na sociedade contemporânea}

"Assim se desenvolve o novo e surpreendente processo de desterritorilização, uma caracteristica essencial da sociedade global em formação. Formam-se estruturas de poder econômico, politico, social e cultural internacionais, mundiais ou globais descentrados, sem qualquer localização nitida neste ou naquele lugar, região ou nação. Estão presentes em muitos lugares, nações, continentes, parecendo flutuar por sobre Estados e fronteiras, moedas e linguas, grupos e classes, movimentos sociais e partidos politicos." ( IANNI 1992).

$O$ final do século $\mathrm{XX}$ representou um momento de questionamento sem precedentes na história da humanidade e do pensamento social. Esse questionamento se traduziu por um intenso debate acerca da modernidade e de todas as suas implicações por diversos autores tais como: Milton Santos, Ianni, Giddens, Habermas, Touraine, Boaventura Sousa Santos, Bauman, entre outros.

$\mathrm{Na}$ área do conhecimento científico é consensual a afirmação de que, desde as últimas décadas do Século XX verifica-se, por um lado, um excepcional crescimento do processo de globalização da economia acompanhado de extraordinário desenvolvimento tecnológico e, de outro, observa-se uma crise generalizada da sociedade industrial, com repercussões nos aspectos social, politico, ideológico, cultural, ambiental, ético e moral. (LEFF 2001; HANNIGAN 1995; SACHS 1994; IANNI 1996; SANTOS M 1997).

De acordo com SANTOS M (1994) a globalização produz "uma nova cara do espaço e do tempo" - o meio-técnico-científico-informacional, com a inclusão da ciência, da tecnologia e da informação ao meio geográfico. Um novo sistema de natureza - a natureza artificializada ou tecnicizada - forma a nova paisagem do espaço geográfico do mundo atual. 
Nas mais diversas áreas da produção do conhecimento, vários autores corroboram a idéia de que a crise social generalizada no século XXI manifesta-se, no aspecto cultural e filosófico, por um rompimento com a certeza positivista de progresso que orientou e acompanhou os fins capitalistas até agora, levando a um crescente questionamento do modelo dominante de desenvolvimento (SANTOS BS 1995; SACHS 1994).

Para IANNI (1996), um dos principais sociólogos brasileiros da contemporaneidade, e um dos intelectuais que se dedicou ao tema, a globalização traz no seu bojo uma característica essencial: um processo intenso de desterritorilização que produz profundas modificações em todos os campos da estrutura social com a criação de novas situações e problemas para todos os povos do mundo.

“... a desterritorialização manifesta-se tanto na esfera da economia, como na politica e cultura. Todos os niveis da vida social, em alguma medida, são alcançados pelo deslocamento ou dissolução de fronteiras, raizes, centros decisórios, pontos de referência. As relações, processos e estruturas globais fazem com que tudo se movimente em relações conhecidas e desconhecidas, conexas e contraditórias" (IANNI 1996).

A desterritorialização significa o processo que rompe as referências das áreas territoriais, ignorando as fronteiras políticas, sociais e culturais. O território que sempre foi a base, o marco-divisor do Estado-Nação, estreitamente ligado à idéia de poder, de gestão e de domínio sobre uma determinada área geográfica é transformado pelo processo de globalização, tendo a dispersão dos pontos de referência e também dos centros de decisão.

Esta desterritorialização produz uma compressão do espaço e do tempo, que no entendimento de HARVEY (1992), é gerador de um "impacto desorientado $e$ desruptivo sobre as práticas politico-econômicas, sobre o equilibrio do poder de classe, bem como sobre a vida social e cultural". Produzindo alteração no espaço e no tempo, acentua as condições de solidão e alienação, rompendo significados de 
conceitos, categorias, leis e valores. Para IANNI (1996), neste contexto é que aparece o simulacro no lugar da realidade, na medida que remove os quadros mentais de referência da sociedade nacional, do Estado-Nação.

Diversos autores da contemporaneidade vêm corroborando essa idéia de que, no plano político, esse momento histórico que se apresenta evidencia uma descrença generalizada frente aos instrumentos políticos tradicionais, o que se faz sentir pelo enfraquecimento do Estado-Nação, pela impossibilidade de reconhecer-se um "locus" único para o poder e pela geração de desequilíbrios sociais e econômicos que se traduzem em taxas crescentes de desemprego, no aumento da marginalidade social, nas disputas violentas entre diferentes grupos étnicos e raciais, na desagregação social, na transnacionalização do capital e no desenvolvimento extraordinário da tecnologia (GIDDENS 1995; IANNI 1996; SANTOS BS 1995; SANTOS M 1997; LEONARDI 1995; DOWBOR 1999).

Retomando o pensamento de SANTOS M (1997), tem-se que o meio técnicocientífico-informacional, como uma base desse momento histórico em que se vive, é que vai constituir a tecnosfera, cuja dimensão atinge toda a extensão geográfica do planeta, constituindo a "metrópole total", conseqüência do processo da urbanização. Ainda, de acordo com o autor referido, a tecnosfera, por sua vez, engendra a psicosfera - campo das idéias, crenças, paixões, comportamentos, sentidos que decorrem da interação do ser com o meio criado pelo próprio engenho humano, o que se pode chamar de espaço do cotidiano.

“Tecnosfera e psicosfera são os dois pilares com os quais o meio técnico-científico introduz a racionalidade $e$ a contraracionalidade no próprio conteúdo do território" (SANTOS M 1997 p.204).

No plano da vida cotidiana, segundo ORTIZ (1994), a globalização ou a mundialização (como este autor a denomina), não se sustenta apenas sobre uma base técnica. Quando os autores se referem a uma "sociedade global", remetem o investigador a uma totalidade que penetra e atravessa as diversas formações sociais do planeta. Há uma diluição das fronteiras, o que faz com que as especificidades 
nacionais e culturais sejam, de maneira diferenciada, atravessadas pela modernidademundo, que se realiza através da diversidade. Há um universo habitado por objetos compartilhados em ampla escala: produtos da empresa McDonald's ${ }^{\mathbb{R}}$, Coca-Cola ${ }^{\mathbb{R}}$, calças Levi's ${ }^{{ }^{B}}$ são hoje consumidos em todos os cantos do mundo por uma parcela privilegiada da população. As mesmas imagens da televisão são vistas em todo o mundo, passando a fazer parte do objeto do desejo de milhares de pessoas, pelo mundo afora, os mesmos carros, os mesmos eletrodomésticos.

O que parece bastante paradoxal, a um olhar mais distraido, é o fato de que, embora o conceito de território esteja bastante ligado à idéia de poder e de domínio sobre um determinado espaço, por outro lado, percebe-se, também, um forte sentimento de territorialidade e uma consciência de pertencimento que sobrevivem e persistem entre populações que habitam e formam um território, a exemplo de determinados grupos étnicos. De acordo com VÉRAS (2003), o tema das territorialidades, das (des) territorializações e (re) territorializações deixa marcas significativas no espaço urbano, tanto na arquitetura como nos estilos de vida, cultura, hábitos alimentares, espaços públicos, tanto em aspectos objetivos, como naqueles que abrangem a subjetividade dos indivíduos, o que aponta também para o reconhecimento de uma dimensão espacial da cidadania, em que coexistem aspectos como a alteridade e a multiculturalidade, condições básicas para um pluralismo cultural. Memória e direito ao "lugar", laços de vizinhança e de solidariedade, conterraneidade e sociabilidade são alguns elementos que podem ser observados na construção de uma dimensão espacial da cidadania, que possibilita a construção da territorialização, como antítese a uma desterritorialização desmesurada, típica da etapa atual da globalização

Todavia, é consenso que essa grande transformação social, econômica e da produçào, ocorrida no processo de globalizaçào, está longe de possibilitar uma melhoria eqüitativa da qualidade de vida dos cidadãos e cidadãs, pois o que se percebe, nos dias atuais, é que, quanto mais a sociedade industrial e econômica se globaliza, mais se amplia o fosso entre a riqueza e a pobreza, tanto nos países do Sul quanto nos do Norte, o que acentua a contrapartida do processo de globalização, que é o processo de fragmentação. (SACHS 1994; IANNI 1996; SANTOS BS 1995; HARVEY 1992). 
A fragmentação pode ser considerada tanto do indivíduo como do espaço e da sociedade. É resultante e está intrinsecamente ligada ao processo de formação capitalista, devido ao conflito entre processo de produção socializada e respectiva apropriação privada, somada às condições de concentração e centralização do capital tanto a nível local, nacional, regional continental e internacional; tal como ocorre no momento atual da globalização, como nunca ocorreu em nenhuma outra fase do capitalismo (CHAUÍ 1995).

Para CHAUÍ (1995), fragmentando e dispensando a esfera da produção por meio da terceirização, usando a velocidade das mudanças científicas, tecnológicas e dos meios de informação, operando com o desemprego e com a inflação estruturais, o neoliberalismo fez com que o capital passasse a acumular-se de forma oposta à forma clássica, isto é, não por absorção e incorporação crescente da maioria da sociedade via trabalho, mas polarizando-a em dois blocos: o da carência absoluta e do privilégio absoluto.

É importante considerar que, embora o presente processo de globalização traga o domínio, a centralização, a concentração, a diferenciação do mundo pela associação das grandes organizações e corporações mundiais, traz também um resultado bastante diferenciado no que se refere aos diferentes espaços globais, que se apresentam com diferentes conteúdos técnico, informacional e comunicacional, resultando em diferentes densidades (SANTOS M 1997).

A ilusão de que a informática, a telemática, a biotecnologia, a engenharia genética e os novos materiais criados projetam o futuro para uma unificação planetária e para a criação de uma sociedade mundial é posta em cheque quando se presencia que o novo meio técnico-científico-tecnológico conduz também a efeitos perversos e deletérios, a exemplo das grandes catástrofes ecológicas que aconteceram na segunda metade do Século XX, tais como: Chernobyl, Three Mile Island, Bhopal, entre outras, e que continuam representando riscos para a vida no planeta, neste início de século.

Poluição do ar nas grandes cidades, devastação das florestas, contaminação dos mares, acidentes nucleares, alterações climáticas, rompimento da camada de ozônio, efeito estufa e inundações são riscos que afetam a sociedade como um todo, 
produzindo medo e insegurança, comprometendo, dessa maneira, o campo da psicosfera, o que resulta num grande mal estar civilizatório. (SANTOS BS 1995; SANTOS M 1997; BECK 2000).

Assim como a economia, a política e a cultura, a questão ambiental também se mundializou. A preocupação $\mathrm{com}$ as grandes questões ecológicas e socioambientais afeta toda a população do planeta, como bens ou males universais (SOBRAL 1997; HOGAN 1995).

Na discussão do futuro das sociedades contemporâneas, GIDDENS (1999) enfatiza a questão ambiental como um dos dilemas fundamentais da atualidade. Para esse autor, nenhum programa integrado para políticas sociais pode ser desenvolvido sem que respostas, ainda que provisórias, sejam dadas a esse tema.

De acordo com GIDDENS (1991), "na modernidade tardia", conceito que o autor utiliza para referir-se às características peculiares do momento atual da sociedade, os problemas ambientais e os riscos decorrentes são simultaneamente globais e locais. Segundo este autor, a modernidade, na sua forma inicial e em posteriores formas institucionais, tornou-se uma questão fundamental na análise sociológica, especialmente, no século XX e no início do século XXI. Segundo essa compreensão, as instituições modernas diferem das formas anteriores da ordem social, tanto pelo seu dinamismo como pelo seu impacto global.

A modernidade, para Giddens, é uma ordem pós-tradicional que diz respeito a costumes, estilos de vida e organizações sociais que emergiram na Europa a partir do Século XVII e que acabaram por se disseminar e difundir para o mundo inteiro; dessa forma, a modernidade veio a se tornar hegemônica, especialmente no final do Século XX. Ainda, de acordo com Giddens, o final do século XX colocou para a humanidade a perspectiva de mudança para uma nova era, a qual vem exigindo profundas análises das possibilidades, da emergência de um novo sistema social em que a sociedade da informática e de consumo se contrapõe ao fím de uma época. Para este autor, o que está em jogo são os intensos questionamentos sobre as transformações estruturais, que se fundamentam na reorientação de um sistema com base na produção de bens materiais, para outro, orientado pela produção do conhecimento e da informação. 
A modernidade tardia, segundo GIDDENS (1991) não deve ser confundida com um marco social em que as certezas e hábitos da tradição tenham sido substituídos pelas certezas do conhecimento racional. Para Giddens, os questionamentos sobre as transformações estruturais são de ordem filosófica ou epistemológica, que poderão desmistificar a utopia da segurança e da confiança no futuro. Enquanto a sociedade atual reduz os riscos em certas áreas e modos de vida, por outro lado, introduz novos parâmetros de risco desconhecidos em épocas precedentes, derivados do caráter globalizado dos sistemas sociais da modernidade. (GIDDENS 1995).

Nesse sentido, GIDDENS (1991) se contrapõe às teorias pós-modernas, colocando-se do ponto de vista de uma dimensão caracterizada pela desorientação, por não ser mais possivel obter conhecimento total sobre a sociedade e sobre os problemas, cada vez mais complexos, que advêm desse tipo de sociedade, o que os tornam fora do controle imediato, especialmente por parte da ciência, que não ocupa mais um lugar de destaque na solução dos mesmos. Ao invés de estar entrando num período pós-moderno, o que está sendo alcançado é um tempo em que as conseqüências da modernidade estão mais radicalizadas e universalizadas. Para tanto, Giddens aponta, como perspectiva, a descontinuidade da modernidade e de suas conseqüências.

Concentrando sua análise nas descontinuidades históricas e na comparação entre as instituições sociais modernas e as de ordem sociais tradicionais, Giddens (1991, p.15) observa três aspectos primordiais, a saber: i) ritmo de mudança; ii) escopo da mudança e iii) natureza intrinseca das instituições modernas.

i) O ritmo das mudanças na modernidade é completamente diferente daqueles existentes em outros períodos históricos, e diz respeito, não só às questões tecnológicas, mas também a outras esferas da vida social;

ii) O escopo da mudança é difuso e atinge, virtualmente, diferentes partes geográficas do mundo;

iii) A natureza intrínseca das instituições modernas se alterou de forma radical, sem precedentes em outros períodos históricos. Os exemplos 
mais significativos são o sistema político do Estado-Nação, a dependência da produção de fontes de energia não-renováveis ou inanimadas e a completa transformação, em mercadoria, de produtos e do trabalho assalariado.

Como um exemplo de descontinuidade histórica, Giddens cita a cidade. Para este autor, o urbanismo moderno é ordenado segundo princípios completamente diferentes dos que estabeleceram em períodos anteriores, a cidade pré-moderna em relação ao campo, de tal forma que o espaço da cidade passou a representar a melhor expressão das conseqüências da modernidade, onde temas como segurança/perigo e confiança/risco representam os mais significativos aspectos do questionamento das utopias desenvolvidas com a modernidade deste início de século XXI, o que se configura como aparente contradição, na medida em que, se por um lado a modernidade ofereceu à humanidade o desenvolvimento de instituições sociais modernas com possibilidade de uma existência segura e prazerosa, numa escala jamais sentida; por outro, essas mesmas instituições oferecem também um lado sombrio, que se constituem em perigo e insegurança para a humanidade.

Enfocada dessa maneira, à luz do pensamento de Giddens, no contexto de modernidade tardia, a degradação socioambiental provocada pela intervenção humana ou por fenômenos naturais prenuncia-se como uma problemática social e ecológica de alcance planetário, que permeia todos os âmbitos da organização social, criando espaços de conflitos e tensões de interesses estabelecidos em relação à apropriação dos recursos naturais e aos grupos de pressão institucionalizados, sendo que o modo como a problemática for enfrentada pode redundar num conflito global (SANTOS BS 1995).

Como se verifica na contemporaneidade, os problemas socioambientais passaram a ser vistos de forma global e local, dessa maneira, as estratégias para se lidar com eles também transitam entre o local e o global. 


\subsection{Alternativas para a saída da crise ambiental}

Cientistas e pesquisadores de áreas diversas têm investigado sobre as possibilidades de saída para essa crise que parece ainda muito longe de ser alcançada. Para autores como TIEZZI (1988) e CAPRA (1982), a saida não será, por certo, a manutenção do modelo de desenvolvimento hegemônico. Para esses autores, é necessário desencadear um processo radical de libertação das potencialidades humanas reais ou de um "cosmopolitismo emancipatório", enfim, um processo que leve a uma sociedade baseada no equilibrio com a natureza e na "qualidade de vida".

“(...) em nossa civilização, modificamos a tal ponto nosso meio ambiente durante essa evolução cultural, que perdemos o contato com nossa base biológica e ecológica mais do que qualquer outra civilização do passado. Essa separação manifesta-se numa flagrante disparidade entre o desenvolvimento do poder intelectual, o conhecimento científico $e$ as qualificações tecnológicas, por um lado, e a sabedoria, a espiritualidade e a ética por outra". (CAPRA 1982, p. 39).

A concepção do universo como uma rede interligada de relações intrinsecamente dinâmicas torna-se cada vez mais corrente nos meios científicos, transcendendo-se assim a visão cartesiana do mundo e conduzindo a uma concepção holistica e dinâmica do universo. Nesta linha de pensamento, CAPRA (1982) enfatiza que, para abordar a questão ambiental, é necessário superar qualquer análise mecanicista cartesiana, que leve a atitudes antiecológicas.

“A compreensão dos ecossistemas é dificultada pela própria natureza da mente racional. O pensamento racional é linear, ao passo que a consciência ecológica decorre de uma intuição de sistemas não lineares" (CAPRA 1982, p. 38).

Para GUATTARI (1995), o desafio que a sociedade enfrenta hoje, no que se refere à questão ambiental, é o de superar os modelos tradicionais reproduzidos no seio da sociedade, seja via partidos políticos, seja via movimentos sociais. 
“(...) encarar seus efeitos no dominio da ecologia mental, no seio da vida cotidiana individual, doméstica, conjugal, de vizinhança, de criação e de ética pessoal. Longe de buscar um consenso cretinizante e infantilizante, a questão será no futuro, a de cultivar o dissenso e a produção singular da existência." (GUATTARI 1995, p.33-34).

"Parece-me essencial que se organizem assim novas práticas micro-politicas e micro-sociais, novas solidariedades, uma nova suavidade juntamente com novas práticas estéticas e novas práticas analíticas das formações do inconsciente. Parece-me que esta é a única via possível para que as práticas sociais e políticas saiam dessa situação, quero dizer, para que elas trabalhem para a humanidade e não um simples reequilibrio permanente do universo das semióticas capitalísticas" (GUATTARI 1995, p. 35).

Autores adeptos da ecologia generalizada com ênfase na ecologia social propõem, como solução para a questão ambiental, que a economia incorpore as premissas ecológicas ao seu pensamento e que a ecologia se expanda para várias áreas. Como exemplo, pode-se citar MORIN e KERN (1995), que afirmam ser necessário conciliar as necessidades de proteção ecológica e as necessidades de desenvolvimento econômico do Terceiro Mundo. Para esses autores, a idéia de desenvolvimento sustentável é contraditória, uma vez que, por um lado, a idéia de desenvolvimento comporta aumento das poluições e, por outro, a idéia de meio ambiente requer limitação das poluições. Portanto, existe a necessidade de aprofundar uma reflexão em torno desse conceito baseando-se "na concepção autoeco-organizadora, considerando a ligação de todo sistema vivo, humano ou social a seu ambiente". (MORIN \& KERN 1995, p. 74).

LEFF (2001) enfatiza que a problemática ambiental gerou, e vem gerando mudanças globais em sistemas socioambientais complexos que afetam as condições de sustentabilidade do planeta, apontando a necessidade de internalizar as bases 
ecológicas e os princípios jurídicos e sociais para a gestão democrática dos recursos naturais.

Dentre as várias soluções propostas cabe ressaltar a de SACHS (1994), que propõe que, em todo o planejamento de desenvolvimento, sejam levadas em conta as seis dimensões da sustentabilidade: a social, a econômica, a ecológica, a espacial, a cultural e a política.

Alguns autores, numa avaliação crítica ao modelo de desenvolvimento sustentável preconizado pelo Relatório Brundtland (CNUMAD, 1991), propõem uma reflexão baseada no conceito de Sociedade Sustentável.

“.... que é aquela que mantém o estoque de capital natural ou compensa pelo desenvolvimento do capital tecnológico uma reduzida depleção do capital natural, permitindo assim o desenvolvimento das gerações futuras. Numa sociedade sustentável o progresso é medido pela qualidade de vida (saúde, longevidade, maturidade psicológica, educação, ambiente limpo, espírito comunitário e lazer criativo) ao invés de pelo puro consumo material' (VIOLA \& FERREIRA 1996, p.10).

Outros autores apontam algumas pistas para a saída da situação ambiental crítica que ora se apresenta, dentre as quais se destacam, além de políticas públicas firmes e eficientes, a participação das populações envolvidas e a educação ambiental (SACHS 1994; GIDDENS 1999).

Como afirma REIGOTA (1999), a complexidade cultural e política contemporânea imprime um caráter estratégico às questões ecológicas, inseridas nessa complexidade e ocupando um papel estratégico, na medida em que os problemas ecológicos se ampliam, não obedecem a fronteiras geográficas e exigem o envolvimento de pessoas com diferentes características sócio-culturais na tentativa de encontrar soluções. Para tanto, REIGOTA (1995) propõe que a educação ambiental procure estabelecer uma nova aliança entre a humanidade e a natureza, na qual a ética permeie todas as relações sociais, políticas e econômicas. Essa educação 
deve basear-se no diálogo entre gerações e culturas em busca do que o autor chama de tripla cidadania: local, continental e planetária, e deve fundamentar-se na liberdade, tendo implícita a perspectiva de uma sociedade mais justa, tanto em nível nacional quanto internacional.

SORRENTINO \& TASSARA (1999), em uma reflexão sobre a importância da educação para o desenvolvimento sustentável enfatizam a necessidade de levar as discussões sobre a questão ambiental para as instâncias locais de poder, dentro de uma perspectiva participativa. Para esses autores, “(...) cada poder local tem a tarefa de fomentar politicas que estimulem a participação dos individuos e grupos em seus "pedaços", de forma que a melhoria do meio ambiente e qualidade de vida seja o resultado do exercicio constante de uma cidadania local/planetária..." . (SORRENTINO \& TASSARA 1999, p. 187).

Como bem coloca BENEVIDES (1991), se por um lado, o princípio da participação popular no governo pode ser considerado "um remédio contra a tradição oligárquica e patrimonialista", por outro lado, o processo de democratização depende, também, das possibilidades de mudança nos costumes e nas mentalidades que representam obstáculos à efetiva legitimação da participação. Neste sentido, reforça-se a importância da educação para a cidadania como "... meio de transformar a capacidade de engajamento sócio político dos atores relevantes e como possibilidade de motivar e incentivar as diversas formas de participação em potenciais fatores de dinamização da sociedade e da ampliação do controle social da coisa pública (JACOBI 1997, p.2).

Um importante aspecto a ser observado quando se fala em reforçar a educação para a cidadania é a necessidade de ampliação dos canais de participação. JACOBI (1997) constata que apenas uma pequena parcela da população vem se engajando em movimentos sociais e associações civis.

Tal constatação vai ao encontro do ideário proposto por SANTOS BS (1995) que enfatiza a necessidade da emergência de movimentos (tais como o ecológico, dos povos indígenas, de operários de vários países, o de mulheres e outros) que carregam em si a negação dialética para os dilemas referidos. Para tanto, propõe a busca de "novas energias emancipatórias" para transformá-las em "energias regulatórias", no 
sentido da descontinuidade do processo de negação da cidadania e da introdução de uma mudança paradigmática. Por meio das energias emancipatórias, o autor propõe que sejam pensadas e projetadas uma "contra-globalização", de modo a torná-la hegemônica para poder chegar a um outro estágio civilizatório.

Segundo SANTOS BS (1995), as promessas da modernidade, isto é, as soluções de compromisso já experimentadas historicamente entre Estado, mercado e comunidade e suas correspondentes racionalidades, levaram a civilização a um oceano de irracionalidades acumuladas, do qual são testemunhas a degradação ambiental, as grandes concentraçòes urbanas, as disparidades e desigualdades sociais, a fome e a miséria.

Para DOWBOR (1999), no campo da economia política, há que se desenhar sistemas flexíveis de gestão social, capazes de comportar as transformações econômicas e sociais ora em processo. De acordo com este autor, uma gestão social flexível não é viável sem um efetivo controle social, característica primordial de sistemas democráticos. Como exemplo de gestão social flexível, Dowbor elenca uma série de iniciativas, tais como: orçamento participativo, organização da comunidade em torno de seus interesses, descentralização dos recursos públicos, organização da informação ao cidadão e outras medidas que se constituem em progressos civilizatórios, uma vez que envolvem a sociedade e geram as dimensões institucionais que mais se aproximam de uma democracia efetiva.

O poder mobilizador das utopias também é ressaltado por esses autores, como necessidade de construir um novo paradigma em direção à construção de uma sociedade mais sustentável, em que homens, mulheres e comunidades possam desfrutar de uma melhor qualidade de vida e de um estado de maior felicidade.

“(...) não podemos esquecer o poder mobilizador das utopias que sensibilizaram e convocaram a humanidade para a ação. Hoje, mais do nunca, no inicio de um novo século, diante do enorme poder que temos de construire destruir coisas belas e de nos percebermos enquanto espécie, compartilhando com milhares de outras este pequeno planeta, maravilhados com a vida e tristes com a miséria que ainda impera entre nós, a utopia está em acreditar e agir na construção da possibilidade de sermos, cada um, integro, honesto, humilde, solidário, carinhoso e de sermos todos - individuos, comunidades e humanidade-felizes." (SORRENTINO \& TASSARA 1999, p.190). 
Dentro dessa linha de pensamento ressalta-se a importância de estudos que levem em conta as representações, os sentidos, os significados e as práticas das populações envolvidas, nos quais essas várias dimensões possam ser conhecidas, modificadas e reelaboradas. Nesse sentido, a compreensão das diferentes representações, sentidos e significados deve constituir no fundamento da negociação e da solução dos problemas socioambientais e da busca do desenvolvimento de "novas sensibilidades" sobre a relação humana e o ambiente e do estabelecimento de uma articulação para o desenvolvimento local.

\subsection{O advento da sociologia ambiental}

Pela importância de que se reveste, a questão ambiental vem sendo investigada por áreas multidisciplinares e interdisciplinares do conhecimento. No que se refere ao desenvolvimento de um campo específico da sociologia ambiental como produção científica e acadêmica, autores como PAEHLKE (1989), MACCORMICK (1992) e ECKERSLEY (1995) correlacionam o advento, da sociologia ambiental com a emergência dos movimentos sociais, surgidos no início dos anos de 1960 com a constatação da situação emergencial de degradação dos recursos naturais decorrente do desenvolvimento extraordinário do industrialismo, ocorrido na época. A crescente pressão e intensificação de impactos negativos ao ambiente, devido à expansão econômica, criaram as condições para que as questões ambientais se tornassem um elemento central no campo da sociologia, especialmente após a década de 1970, principalmente em função do crescimento do movimento ambientalista mundial e à ampliação crescente do debate sobre os efeitos globais dos riscos ambientais.

Numa revisão às investigações no campo da teoria social, autores como GOLDBLATT (1996) e BUTTEL, (2000) têm se referido à demora da sociologia em ter se embrenhado nas investigações no campo ambiental, fator que seria decorrente de os autores pioneiros da sociologia clássica - Émile Dürkheim, Max Weber e Karl Marx, assim como os seus seguidores, até a década de 1960 - não terem abordado a relação entre sociedade e natureza de forma mais profunda, o que 
tornou a área de ciências sociais carente de um corpo teórico consistente para o entendimento e interpretação da questão ambiental emergente.

GOLDBLATT (1996), ao discorrer sobre as limitações da teoria social clássica na explicação dos problemas decorrentes da degradação ambiental, correlacionou tal degradação, em primeiro lugar, ao fato de a teoria social não possuir uma estrutura conceitual adequada para compreender as interações complexas entre sociedades e meio ambiente; e em segundo lugar, o autor destaca o fato de o foco de atenção ter sido centrado, exclusivamente nos meios pelos quais as sociedades humanas transformaram o seu ambiente, sem focarem os efeitos negativos dessas transformações.

Como explicações para o fato de os sociólogos não terem dado, logo no início, a devida importância para a problemática ambiental em suas construções teóricas, HANNIGAN (1995) refere-se a dois motivos principais: o primeiro seria no que concerne às falhas do determinismo geográfico e biológico, e à visão conservadora dessas influências sobre o entendimento das mudanças e conflitos sociais, teoria esta absorvida pelo discurso sociológico em seus conceitos "darwinistas de evolução", "seleção natural" e a "sobrevivência dos mais aptos"; e a segunda seria atribuída ao próprio pensamento vigente na época, que privilegiava a sociologia da modernização. O que hoje é entendido como preocupação ambiental, à época, seria visto como atraso e obstáculo ao progresso e à modernização da sociedade. Por sua vez, os sociólogos de tradição marxista, críticos ao paradigma desenvolvimentista, tendiam a ver a problemática ambiental como um desvio das questões cruciais da luta de classes. Mesmo quando a gravidade da degradação ambiental foi reconhecida, os críticos de esquerda tendiam a direcionar as suas teorias sobre as relações de poder subjacentes a esta crise, em vez de focalizar os fatores que a relacionavam com o ambiente (HANNIGAN, 1995).

Foi só a partir de 1970, na esteira dos movimentos ambientalistas, que começam a despontar grupos de sociólogos voltados para a importância e a relevância da temática ambiental, contribuindo, com seus estudos, para que a questão ambiental ocupe hoje um espaço mais abrangente, tanto nos meios de comunicação 
quanto nos acadêmicos e na sociedade como um todo (REDCLIFT \& WOODGATE 1997; HANNINGAN 1995; CATTON \& DUNLAP 1998).

Em meados de 1970, as associações sociológicas norte-americanas (Associação Sociológica Americana, Associação Sociológica Rural, Sociedade para o Estudo dos Problemas Sociais) haviam estabelecido seções relacionadas com a sociologia ambiental; na Europa, grande parte dos estudos na área ambiental direcionava-se para o entendimento da emergência dos "verdes" como força política. (DUNLAP \& CATTON, 1979).

Nesse sentido, a questão ambiental transcendeu os limites de sua inserção inicial, para tornar-se uma preocupação permanente na área da sociologia, consolidando-se como um fenômeno global, constituído por diversas dimensões interdependentes, sobre as quais passaram a se debruçar governos, pesquisadores, empresas, instituições, organizações não governamentais, dentre outros.

BUTTEL (2000); HANNIGAN (1995); REDDCLIFT (1997); GIDDENS (1991) e BECK (1995) são alguns autores que se destacaram no período compreendido entre 1970 a 1995, nos estudos em que a sociologia ambiental assumiu uma posição significativa em investigações sobre divergências e conflitos a respeito da natureza, das causas e das conseqüências dos problemas ambientais. HANNIGAN (1995) sugere que tenha havido neste período, uma grande oscilação nos interesses relativos à questão ambiental. Por sua vez, BUTTEL (2000) refere-se, de forma pessimista à sociologia ambiental, no sentido de ter se tornado apenas "uma outra especialização sociológica". DUNLAP \& CATTON ressaltam a importância do ressurgimento do interesse pelas questões ambientais nos anos 1990, especialmente aqueles que têm um escopo global. Para esses autores, tal interesse estimulou uma renovação na sociologia ambiental, não só nos Estados Unidos, como no mundo inteiro. 


\subsubsection{As correntes na sociologia ambiental}

No cenário das discussões sobre a problemática ambiental, à luz das Ciências Sociais, o embate que parece prevalecer ainda é aquele entre realistas $\mathrm{e}$ construcionistas $^{6}$ sociais perpassando toda a sociologia ambiental. Os realistas defendem a existência objetiva dos problemas ambientais, independente das formas pelas quais os atores sociais os percebem. Os construcionistas sociais concentram-se seus esforços na compreensão das representações, significados e sentidos que grupos ou individuos atribuem sobre um problema ambiental ou ainda, sobre a forma como uma problemática ambiental é socialmente produzida (HANNIGAN 1995; GUIVANT 2002).

Os realistas ambientais questionam a postura dos construcionistas, acusandoos por terem relegado a realidade dos problemas ambientais a um relativismo passivel de levar a conseqüências que nada contribuem para a solução dos problemas. Por seu lado, os construcionistas sociais argumentam que os realistas estão perdendo a possibilidade de entendimento a respeito da maneira e do por que determinados temas passam, em certos momentos, a serem considerados como relevantes e reais.

Dentre as principais contribuições, dentro da sociologia ambiental identificada com a corrente do realismo ambiental, destaca-se a de Catton e Dunlap que, em 1978, formularam uma proposta de se estudar as relações entre meio ambiente e sociedade por meio do "novo paradigma ecológico", segundo o qual, os serem humanos eram considerados como parte dos ecossistemas que influenciariam suas ações, assim como a sociedade.

No tocante ao construcionismo social, teóricos como HANNIGAN (1995) e YEARLEY (1996) são seus maiores expoentes e aqueles que mais têm desenvolvido investigações consistentes sobre a temática ambiental, a partir da proposição de entendimento da maneira pela qual as pessoas atribuem sentidos e significados aos seus mundos. Os construcionistas sociais advertem para a necessidade de

\footnotetext{
No original o autor usa o termo constructionist.Optou-se por manter os neologismos construcionistas e construcionismo, os quais aparecerão sempre em itálico.
} 
compreensão dos problemas ambientais como construções sociais buscando entender a forma como esses problemas são formulados, legitimados e contestados.

Esta postura propicia alguns elementos para a discussão sobre como surgem, na esfera pública, problemáticas ambientais de relevância local que se demonstram globais, a partir da intervenção de grupos e indivíduos.

Dentre os estudos que se destacam, na década de 1990, para o desenvolvimento da sociologia ambiental, BUTTEL (2000) aponta que as contribuições mais significativas para a área são os trabalhos de BECK (1992) e de GIDDENS (1991) os quais desenvolveram uma teoria sobre a sociedade de risco.

GIDDENS (1991) e BECK (1992) alinham-se no conceito de modernização reflexiva e buscam entender o que sustenta o sentido que se dá ao risco como prática social, tendo como foco a função do risco num contexto determinado. Ambos os autores apontam para as especificidades dos riscos como constituintes das sociedades contemporâneas.

Os estudos dos sociólogos holandeses SPAARGAREN \& MOL (1992) enquadram-se na teoria denominada "teoria da modernização ecológica". Embora reconheçam as contribuições oriundas da teoria da modernização reflexiva, SPAARGAREN \& MOL entendem por modernização ecológica uma mudança do processo de industrialização, por meio de novas tecnologias. Enquanto esses autores consideram, a teoria da modernização reflexiva extremamente pessimista, a teoria da modernização ecológica parece pecar pelo excesso de otimismo que depositam na tecnologia do microchip, segundo HANNIGAN (1995).

\subsubsection{A construção de uma sociologia ambiental brasileira}

A sociologia ambiental no Brasil, segundo FREITAS (2003), encontra-se em um estado ainda bastante incipiente, muito embora já possa ser identificado um aumento das investigações a partir desse aporte teórico. Dentre os autores brasileiros que vêm se debruçando sobre o tema podem-se destacar: FERREIRA (2002); HERCULANO (2000), GUIVANT (2002) e FREITAS (2003), entre outros. 
De acordo com FERREIRA (2002), a sociologia ambiental, surgida logo depois da segunda guerra, teve um papel importante na inclusão do debate ambiental nas interpretações sobre as crescentes pressões sociais, com implicações politicas de movimentos comunitários, grupos de protestos e movimentos ecologistas. $\mathrm{O}$ ambiente de pressão crescente e a intensificação dos impactos negativos ao ambiente, devido à expansão econômica, criaram as condições para que as questões ambientais se tornassem um elemento central no campo da sociologia.

Ainda segundo a mesma autora, "a sociologia ambiental assumiu uma posição relevante no estudo das divergências e conflitos sobre a natureza (entendida aqui no seu sentido amplo, tanto natural como construida) e as causas e magnitude dos problemas ambientais, de acordo com os atores envolvidos" (FERREIRA 2002, p 4).

FERREIRA (2002) ressalta a importância do papel do conceito de sociedade de risco, uma das tendências recentes na sociologia ambiental, com sua proposta de análise das relações entre sociedade e ambiente a partir da noção de reflexividade, em que atores não são apenas receptores passivos das forças da modernidade; assim a capacidade de a sociedade refletir sobre os impactos e exercer pressão sobre os grupos de interesses pode propiciar a busca de soluções para os graves problemas ambientais. Este tipo de interpretação dos problemas ambientais deu impulso para o desenvolvimento de novas correntes na sociologia ambiental.

GUIVANT (2002), autora de grande importância para o desenvolvimento de uma sociologia ambiental brasileira, vem se dedicando ao estudo das possíveis contribuições da sociologia ambiental para esclarecimento de questões centrais nas propostas de desenvolvimento rural sustentável e participativo. Para esta autora, os debates no interior da sociologia ambiental, entre realistas e construcionistas sociais podem contribuir para esclarecer divergências importantes.

\subsubsection{Tendência dos estudos ambientais a partir da sociologia ambiental}

Um problema constante para a investigação do ambiente pelos sociólogos tem sido definir o que se constitui o objeto dos estudos. DUNLAP \& CATTON, em artigo crítico de 1979, apontaram com precisão o centro distintivo do campo como 
"uma nova ecologia humana", que incidia sobre a interação entre o ambiente físico, a organização social e o comportamento.

Sendo uma subdisciplina específica dentro das ciências sociais e com "status" próprio no meio acadêmico e científico, a sociologia ambiental vem se dedicando à definição de seu objeto. HERCULANO (2000) identifica cinco diferentes objetos de estudo priorizados, a saber: 1 . atitudes e valores; 2. movimentos ecológicos; 3. riscos tecnológicos; 4. política ambiental; e 5 . desenvolvimento.

Para LEFF (2001), a solução dos problemas ambientais implica na ativação e objetivação de um conjunto de processos sociais para os quais as ciências sociais têm um importante papel a desempenhar. Para tanto, o referido autor destaca uma série de processos que podem se constituir em indicativos de uma agenda de pesquisa:

1. incorporação dos valores do ambiente na ética individual, nos direitos humanos e na norma jurídica dos atores econômicos e sociais;

2. socialização do acesso e apropriação da natureza;

3. democratização dos processos produtivos e do poder político;

4. reformas do Estado que lhe permitam mediar a resolução de conflitos de interesses em torno da propriedade e aproveitamento dos recursos que favoreçam a gestão participativa e descentralizada dos recursos sociais;

5. estabelecimento de uma legislação ambiental eficaz que normatize os agentes econômicos, o governo e a sociedade civil;

6. transformações institucionais que permitam uma administração transetorial do desenvolvimento;

7. reorientação interdisciplinar do desenvolvimento do conhecimento e da formação profissional dos profissionais no campo da saúde coletiva. 
A seguir apresenta-se uma discussão sobre dois conceitos considerados como os mais expressivos, atualmente, na área da sociologia ambiental: a discussão a questão do risco e o construcionismo social.

\subsubsection{A discussão sobre a questão do risco}

Para GIDDENS (1999) a problemática ambiental remete a sociedade para duas questões fundamentais: a relação com o avanço científico e a relação com o risco. Problemas cada vez mais complexos estão se intensificando no cenário urbano, o qual se encontra não só ameaçado, mas também diretamente afetado por riscos e agravos ambientais.

“(...) em parte como uma conseqüência da globalização, a mudança cientifica e tecnológica se acelerou, e sua influência sobre nossas vidas tornou-se tanto mais imediata quanto mais profunda. Poderiamos pensar o "ambiente" como o mundo natural, mas é claro que isso não é mais assim. Muito do que antes era natural é agora produto da atividade humana, ou é influenciado por ela - não somente o mundo externo, incluindo possivelmente o clima da Terra, mas também o "ambiente interno" do corpo. Para melhor ou para pior, a ciência e a tecnologia invadiram o corpo humano, e retraçaram a fronteira entre o que pode ser humanamente realizado e o que simplesmente temos de 'aceitar' da natureza." (GIDDENS 1999, p. 68).

Para esse autor, ao contrário do que acontece na sociedade contemporânea, a ciência e a tecnologia foram vistas, no passado, como coisas alheias à política. As populações vivem no dia-a-dia uma relação interrogatória com as inovações tecnológicas, seja através de movimentos expressos contra usinas de incineração de lixo e contra usinas nucleares, seja por meio de reações contra os alimentos transgênicos. Enfim, o enfrentamento de riscos ecológicos é uma contingência das sociedades humanas contemporâneas e a tomada de decisão nesses contextos não 
pode ser deixada aos "especialistas", mas deve contar com a participação todos os cidadãos, cidadàs, politicos e entidades envolvidos na questão (GIDDENS, 1999).

"Risco não é exatamente o mesmo que perigo. Risco se refere a perigos que buscamos atiramente controntar e araliar. Numa sociedade como a nossa. orientada para o futuro e saturada de informaçào. o tema do risco tune muitas outras áreas da politica cm outros sentidos inteiramente dissimilares: reforma do welfare state, compromisso com os mercados financeiros mundiais, reaçòes à mudanca tecnologica, problemas ecologicos e transformacoos geopoliticas. Todos precisamos enfientar e assumir riscos de uma mancira produtiva" (GIDDENS 1999, p. 73).

BECK (1992), outro importante autor que vem estudando a sociedade contemporànea, também se utiliza do conceito de risco em suas análises sobre a crise ambiental. BECK enfatiza que, apesar de a degradação ambiental atingir tanto os países ricos quanto os pobres, observa-se uma lógica de distribuição de riscos que afeta desigualmente a população.

A tese de BECK parte da premissa de que as naçòes ocidentais passaram de uma sociedade "industrial" ou de "classes", em que a questào central seria a maneira como a riqueza socialmente produzida poderia ser distribuida de forma igualitária reduzindo-se a aspectos negativos como a pobreza, a fome, entre outros, a um paradigma de uma 'sociedade de risco' em que os riscos e os perigos produzidos como parte da modernizaçào, notadamente a poluiçào ambiental, devem ser evitados, minimizados, dramatizados ou canalizados.

Para BECK, uma caracteristica importante da sociedade do risco é a forma como foi quebrado o monopólio das ciências sobre a racionalidade. Para o autor, constitui um paradoxo o fato da ciência torna-se "cada vez mais necessária mas, ao mesmo tempo, cada vez menos suficiente" para a definição socialmente intrínseca da verdade. Dessa maneira, Beck se contrapòe perante a rigidez da "racionalidade científica" construindo uma critica ao que é entendido como progresso. Sob a pressão de um público cada ver mais exigente, novas formas de ciencia "alternativa" $\mathrm{e}$ 
"defensiva" tomam corpo, forçando a ciência a uma crítica interna. Esta cientifização do protesto contra a ciência produz uma nova variedade de peritos científicos que se tornam pioneiros em novos campos de atividade e aplicação. De forma semelhante, é dito que os monopólios da ação política estão a desmoronar-se, abrindo assim a formulação de decisões políticas ao processo de ação coletiva.

Cabe destacar que BECK, no ano 2000, numa revisão crítica ao seu próprio trabalho sobre a sociedade de risco, desenvolvido em 1992, traz à tona um instigante debate com o intuito de aperfeiçoar o entendimento sobre o conceito. BECK considera o conceito de risco como um estado intermediário entre segurança e destruição, no qual a percepção das ameaças de risco determina a forma de entendêlo e as ações empreendidas para controlá-lo.

“(...) é a percepção e definição culturais que constituem os riscos. $O$ risco e a definição pública do risco significam a mesma coisa. Nesse sentido, o que é expresso no risco constitui-se no marco de referência pública tornando-se um tipo de realidade virtual ou mais especificamente, uma virtualidade real". (BECK 2000).

Esta nomeação chama a atenção para o fato de o risco se tornar real a partir de um processo de construção, de sua materialização. Assim sendo, na medida que os riscos têm algum tipo de efeito sobre as populações, a gestão pública dos riscos pode ser considerada parte desse processo de materialização.

Outra característica do conceito de risco, no contexto da sociedade de risco, é precisamente a possibilidade de sintetizar conhecimento e não-intencionalidade. Essa não-intencionalidade é considerada como uma incapacidade simultânea de prever conseqüências, de produzir conhecimentos sobre algo e, ao mesmo tempo, de conhecer o futuro, gerando uma complexificação das formas e possibilidades de cálculo e de governabilidade.

À luz do pensamento de Beck, pode-se inferir que tanto o controle como a sua impossibilidade são manifestações das incertezas construídas. Nesse sentido, haveria duas estratégias fundamentais para lidar com as incertezas: a primeira seria que, perante a impossibilidade de conhecê-las, não haveria outro caminho senão negar a 
existência dos riscos; e a segunda seria que, ao assumir a possibilidade de controlar os riscos, por meio do conhecimento tecnológico com base em estatísticas, uma ampla variedade de fenômenos possam vir a se constituem em riscos intrínsecos, assim sendo haveria a possibilidade de um temor coletivo invadir a estrutura social.

Uma outra caracterização dos riscos, trazida por Beck é que os riscos são "hibridos fabricados pelo homem", isto é: combinação de política, ética, matemática, mídia, tecnologia, definições culturais e percepções. $O$ risco não seria apenas uma noção central para uma variedade de disciplinas e sim a forma em que uma sociedade hibrida, a sociedade reflexiva, se olha, descreve avalia e critica a si própria. Considerados de natureza distinta, os riscos contemporâneos, de tipo ambiental e tecnológico, não produzem apenas efeitos colaterais, e sim se tornam em elementos constitutivos dessas formas de sociedades.

\subsubsection{O construcionismo social: a construção social dos problemas ambientais}

A preocupação por problemas ambientais não é algo constante. Tal como outros problemas sociais, os problemas ambientais se materializam a partir de processos de construção tanto individual como grupal. São os grupos e indivíduos que, ao considerarem preocupante alguma situação particular, organizam-se para propor e implantar ações que contribuam para mudar o panorama.

Nesse sentido, HANNIGAN (1995) e YEARLEY (1996), a partir de uma abordagem da sociologia ambiental construcionista, têm chamado atenção para a compreensão dos problemas ambientais como construções sociais buscando entender a forma como esses problemas são formulados, legitimados e contestados.

Esta abordagem oferece alguns elementos para a discussão sobre como surgem, na esfera pública, problemáticas ambientais de relevância local, que se demonstram globais a partir da intervenção de grupos e indivíduos para, posteriormente fazer seu caminho de volta ao local. HANNIGAN (1995) considera que os problemas ambientais, enquanto moralmente condenados, são ligados mais diretamente às descobertas e exigências científicas. Embora sejam identificados com a intervenção humana, os problemas têm uma "base física", uma materialidade que 
se impõe, quase de modo uniforme, os problemas ambientais são representados como, "reais", "identificáveis" e intrinsecamente "danosos" (HANNIGAN 1995, p.55).

No entanto, HANNIGAN alerta para o perigo da generalização do entendimento de que os problemas ambientais só são construídos a partir das descobertas e exigências cientificas. $O$ autor chama a atenção para o fato de que muitos problemas ambientais só se tornaram publicamente "visíveis" após a movimentação de grupos locais, organizações populares e outros, afetados diretamente pelos efeitos negativos de alguma questão em particular.

Por outro lado, os problemas ambientais são apresentados seguindo uma certa “ordem temporal" de desenvolvimento. Eles podem ser caracterizados a partir de uma certa progressão. Partem geralmente de uma descoberta inicial (evento crítico) até à política de implementação de soluções, que nem sempre conseguem um resultado exitoso.

Alguns autores têm apontado algumas dimensões que podem ser identificadas na construção de problemas ambientais. WIENER (1981) representou a definição coletiva na conformação de um problema específico, identificando três momentos que operam sobrepostos. O primeiro momento é chamado de animação do problema; o segundo de legitimação do problema; e o terceiro, de demonstração do problema.

SOLESBURY (1976) citado por HANNIGAN (1995) identifica também elementos que poderiam orientar a compreensão na formulação de uma problemática ambiental, a saber: liderar a atenção, exigir legitimidade e por fim, apelar para a ação.

Nestes dois autores é nítido o interesse em chamar atenção para o fato de que as questões ambientais não surgem num vazio, mas vão se construindo até se tornarem objeto de debate público e ação específica. Muitos estudos têm apontado para a importância do papel desempenhado pelos profissionais da área médica e cientistas, de uma forma geral, na formulação das exigências ambientais (HANNIGAN 1995). 
Para HANNIGAN (1995), uma maneira efetiva de construir uma problemática ambiental, ou de liderar a atenção seria por meio da utilização de reivindicadores de figuras gráficas, verbalizações apelativas e figuras visuais. Ao formular uma exigência social, ou para liderar a atenção pública, um problema ambiental em potencial deve ser encarado como algo novo que mobilize a atenção pública, tenha relevância dentro do cenário em que está inserida, e que seja factível de compreensão.

De acordo com HANNIGAN (1995) a visibilidade pública de uma problemática ambiental, isto é a preocupação da sociedade com o ambiente e a saúde, não é o resultado de um processo automático, e tampouco essa preocupação é constante, mas flutua ao longo do tempo, aumentando e diminuindo em diferentes períodos. No entanto, há eventos marcantes que auxiliam na compreensão desses processos.

Para esse autor, de acordo com os vários estudos já desenvolvidos sobre a problemática ambiental ao longo da historia, surgem indícios de que, em algum momento este tema teria se tornado uma questão com características de ameaça para a humanidade, no debate público mundial. Como um dos exemplos citados em seu livro, HANNIGAN (1995) traz para a discussão o seguinte fato: como os agrotóxicos, que apareceram em cena na década de 1960 como um fator que poderia contribuir para a expansão da produção agrícola sempre ameaçada por várias pragas, em pouco tempo, passaram a ser vistos como uma fonte de riscos ao ambiente e à saúde humana. Nesse sentido, apresenta-se a seguinte interrogação: como foi que um avanço científico-técnico, constituído pelo desenvolvimento de agroquímicos e considerado como uma panacéia para resolver os problemas das pragas agrícolas transformou-se, em tão pouco tempo numa 'ameaça' para a saúde da humanidade e para o meio ambiente?

Outro tema ambiental que HANNIGAN traz para o debate é o que se refere às chuvas ácidas e seu controle, considerada por este autor uma das controvérsias tecnicamente mais complexas nos últimos tempos.

$\mathrm{Na}$ busca de compreender como foi que se tornou visível ao público a idéia de risco ambiental para a humanidade, HANNIGAN enfatiza que para tal intento 
interessa compreender como são formulados, legitimados e contestados, os diversos argumentos que foram se estabelecendo para a construção de uma problemática ambiental.

A percepção pública de que existiam riscos envolvidos no uso dos agrotóxicos está associado ao surgimento do movimento ambientalista, principalmente nos Estados Unidos, durante os anos 1960. O movimento ambientalista, por sua vez, teve na mesma época uma forte influencia de outros movimentos sociais chamados de movimentos de contracultura: o movimento antinuclear na Europa e o movimento de Direitos Humanos nos Estados Unidos.

Na demonstração da construção social de uma problemática HANNIGAN, (1995) reconstrói a trajetória da polêmica e dos conflitos acerca dos agrotóxicos trazendo à cena a bióloga, ativista e ecologista Rachel Carson que, com seu livro Silent Spring, iniciou uma luta árdua contra os perigos oferecidos pelos pesticidas para toda a vida no planeta, colocando em cheque, a noção de segurança, instituída pela descoberta desses agrotóxicos por parte da indústria química. Segundo HANNIGAN (1995) a autora, embora não tenha sido a pioneira a proclamar sobre os riscos associados ao uso dos agrotóxicos, foi a primeira que conseguiu produzir, na época, o maior impacto diante da opinião pública norte-americana, fazendo com que fosse abalada a confiança do público nas maravilhas da ciência, a exemplo do caso especificamente do DDT, considerado até então como uma panacéia na solução para os males da agricultura. A obra combinava fatos científicos com um discurso literário próprio de uma ativista. Rachel Carson utiliza-se de uma linguagem própria da época, redimensionando os conceitos da guerra para aplicá-los à guerra do homem "contra a natureza". Desse modo, a autora iniciou uma "guerra" contra os fabricantes de agrotóxicos e empresas que aplicavam esses produtos nas diversas atividades agrícolas.

Muito embora não fosse Rachel Carson a única a proclamar os perigos dos agrotóxicos para a cadeia alimentar, foi ela a mais bem sucedida do ponto de vista do debate público. A importância do seu trabalho reside na forma como foram dirigidos os argumentos e o tipo de respostas, surgidas então na sociedade norte-americana, principalmente por parte da industria química, e de outros atores governamentais e 
acadêmicos, o que viria a influenciar fortemente a conformação dos repertórios que hoje circulam acerca dos riscos associados aos agrotóxicos (HANNIGAN 1995).

$\mathrm{Na}$ época a "The New Yorker", revista publicada por "The New York Times", lançou uma serie de cadernos, contendo capítulos do livro mesclados a análises feitas por especialistas. Essa publicação criou um estado de alarme na população americana, o que desencadeou uma reação bastante intensa da industria química dos Estados Unidos. Este acontecimento acabou gerando alguns efeitos surpreendentes, que ainda hoje perduram e que podem ser evidenciados pela grande mobilização da industria química mundial, no sentido de criar um programa global para amenizar as críticas contra os efeitos produzidos pelos agrotóxicos, tanto os de primeira geração, atualmente proibidos, como os posteriores desenvolvimentos da industria no setor químico (GARCIA 2004).

A partir de então, o debate público evoluiu rapidamente tornando a questão dos pesticidas um problema crítico, que exigia o estabelecimento de critérios para a sua utilização. Nesse sentido, pela primeira vez, surgiu a necessidade de regulamentação da industria dos avanços técnicos produzidos por ela (GARCIA 2004).

No final dos anos 1960, o impacto do movimento ambientalista, influenciando o discurso da industria química, já havia se consolidado. Vários anos de ataques e disputas começaram a se refletir no declínio da venda de pesticidas, como o DDT, que seria rapidamente proibido e substituído por agroquímicos mais modernos e de efeitos mais imperceptíveis. Em 1969, um fato foi reconhecido pela industria: uma retórica do medo aos produtos químicos tinha se espalhado por meio de publicações na mídia e nos jornais acadêmicos. Isso resultaria numa estruturação da percepção pública dos riscos ambientais em geral, e dos riscos específicos causados pelos pesticidas. O discurso dos perigos, das ameaças e, posteriormente dos riscos foi se conformando, paulatinamente, num movimento que vai dos efeitos individuais aos efeitos coletivos. (GARCIA 2004).

Paralelamente ao desenvolvimento do movimento ambientalista, a industria fabricante de pesticidas também evoluiu em sua retórica ao longo do tempo, construindo um discurso que pretende contrapor às críticas, cada vez mais 
aprimoradas, a oferta de produtos químicos cada vez mais refinados, ou ao menos propagandeados como tal. A preocupação pública com os pesticidas não tem desaparecido, mas tem se transformado, mesclando-se com outros problemas relevantes da época atual. Pesticidas mais potentes, misturas de pesticidas, herbicidas, ocupam o cenário diário da produção agrícola moderna, seja nos países mais desenvolvidos, criadores dessa tecnologia, seja nos países menos desenvolvidos ou para compradores e comercializadores desses produtos (GARCIA 2004).

Considera-se a obra "Silent Spring" como um exemplo típico de construção de um discurso na era contemporânea, ao estabelecer convenções retóricas que se tornaram, após anos, voz corrente no debate ambientalista (GARCIA 2004).

Uma outra postura para a compreensão dos problemas ambientais, dentro do enfoque construcionista, é a oferecida por YEARLEY (1996). Este autor discute a globalização do interesse pelas questões ambientais, ressaltando que a preocupação pública por esses tipos de problemas tem-se aprofundado e expandido, gerando uma maior sensibilidade do público sobre as mais variadas interconexões biogeográficas do planeta. A contribuição que esse autor traz para o debate centra-se nos espaços onde a presença dos impactos ambientais evidencia-se de modo mais crítico. De acordo com YEARLEY (1996) a definição dos problemas ambientais considerados como "globais", é feita, na maioria das vezes, por órgãos ou agências internacionais que representam os interesses dos países desenvolvidos, minimizando os problemas locais dos países em desenvolvimento.

\subsection{O papel dos novos movimentos sociais: a construção social dos problemas de saúde e ambientais}

Como ficou apontado no capítulo anterior, o movimento ambientalista global teve um papel relevante na formulação, legitimação e disseminação dos problemas ambientais em nível global, da mesma forma que a problemática ambiental e seu foco de observação têm flutuado ao longo do tempo, dependendo de momentos históricos específicos, influenciada pela participação de atores-chave. Esse panorama apresenta alguns elementos importantes, que HANNIGAN (1995) descreve a partir 
de alguns prenúncios da questão, surgidos com o movimento ambientalista em meados da segunda metade do século XX.

Um desses prenúncios a que HANNIGAN se refere foi a publicação do conhecido livro Silent Spring (Primavera Silenciosa), já citado, resultante das pesquisas de Rachel Carson, nos anos 1960. Esta publicação marca a aproximação dos argumentos discursivos mais relevantes ao movimento ambientalista mundial.

"No despertar do fenomenal impacto do livro de Rachel Carson: Silent Spring, nos anos 1960, o conceito de ecologia foi tomado do seu nicho, no âmbito da Biologia aplicada, moralmente revigorada e tornada a explicação mais importante na batalha contra a poluição". (HANNIGAN 1995, p.168).

TOURAINE, um dos principais teóricos no campo da Sociologia, no final da década de 1970, já prenunciava a crise do modelo socialista e a consolidação de uma sociedade pós-industrial, constatando o surgimento dos "novos movimentos sociais": ecológicos, pacifistas, nacionalistas e de gênero (TOURAINE, 1989).

O contexto de surgimento dos movimentos sociais caracterizados como "novos", reporta-se a uma realidade específica. No Primeiro Mundo, eles estão vinculados às condições socioeconômicas e à tradição quanto à participação política e acesso à cultura. TOURAINE e outros autores denominaram de "novos movimentos sociais" o tema das minorias (movimentos étnicos, movimento de mulheres, ambientalistas e outros).

Já na América Latina e especificamente no Brasil, esses "novos movimentos sociais" eram mais voltados às lutas urbanas, com forte ênfase para a questão do consumo de bens e serviços, que se vinculavam às práticas da Igreja Católica na ala da Teologia da Libertação, o que não impediu, porém, a ampliação dos temas de interesse, permitindo, dessa maneira, uma aproximação com os discursos dos "novos movimentos sociais", que se formaram nos países de Primeiro Mundo.

O aparecimento e o fortalecimento dos movimentos ambientalistas no Brasil encontram-se estreitamente vinculados ao momento histórico em que despontaram, 
na sociedade, os novos movimentos sociais, isto é, no período compreendido entre os anos de 1978 e 1989, período que GOHN (1997) denomina de "era da participação".

Segundo GOHN (1997), a denominação "novos movimentos sociais" buscava contrapor-se aos velhos movimentos sociais, expressos no modelo de sociedade amigos de bairro ou associações de moradores. Para essa autora, o que diferenciava os velhos movimentos sociais dos novos, eram as práticas sociais e um estilo de organização da comunidade de maneira diferente, em que se enfatizava, como categoria teórica básica, a autonomia dos participantes.

No tocante aos movimentos ambientalistas, o período compreendido entre 1945 e o início dos anos 1970 foi a época em que o capitalismo experimentou seu mais intenso periodo de crescimento, marcado tanto pela expansão norte-americana quanto pela emergência e consolidação dos "milagres" do Japão e Alemanha. Acreditava-se, naquela época, na inesgotabilidade dos recursos naturais e na infinita capacidade da tecnologia em oferecer respostas a todas as mazelas, o que não aconteceu: pelo contrário, em decorrência da predominância e disseminação desse modelo surgiram sérios desequilíbrios ambientais expressos como "crise ambiental", o que fez com que houvesse uma preocupação por parte da sociedade e dos cientistas, em discutir a questão e as formas para o seu enfrentamento (PALOS 2000).

No início dos anos 1970, um grupo de trinta economistas, cientistas, educadores e empresários industriais reuniu-se em Roma com o objetivo de discutir a degradação ambiental, e outros problemas, tais como a expansão urbana, a perda de fé nas instituições públicas, a rejeição aos valores tradicionais e a deterioração econômica. Esse grupo de pessoas ficou conhecido como o Clube de Roma e publicou, em 1972, um dos trabalhos mais importantes e polêmicos sobre a questão, intitulado Limites do Crescimento (The Limits to Growth).

Segundo esse relatório, as raízes da crise ambiental decorriam do crescimento exponencial da economia e da população. Para alcançar a estabilidade econômica e ecológica, o Clube de Roma propunha o congelamento do crescimento da população global e do capital industrial, mostrando a realidade dos recursos limitados e rediscutindo a tese de Malthus sobre o perigo do crescimento desenfreado da população mundial (BRUSEKE 1995). 
As teses contidas no relatório The Limits to Growth possibilitaram o acirramento do debate sobre os riscos da degradação ambiental, uma vez que diversos teóricos e pesquisadores sobre a questão trataram de levantar críticas veementes aos prognósticos catastróficos do relatório. A partir do Clube de Roma, o debate entre desenvolvimento, desequilibrio socioeconômico e questão ambiental ganhou concretude e embasa as diversas divergências e desentendimentos no discurso global (BRUSEKE 1995).

A questão ambiental foi adquirindo significativa importância, tanto na comunidade científica mundial, quanto em níveis locais, conforme se depreende do elevado número de conferências, declarações, encontros, acordos, relatórios. Dentre essas manifestações pode-se destacar a grande discussão internacional, que foi a Primeira Conferência das Nações Unidas sobre Meio Ambiente e Desenvolvimento Humano, realizada na cidade de Estocolmo, Suécia, no ano de 1972.

Esta conferência trouxe, por um lado, o reconhecimento generalizado da profunda relação entre meio ambiente e desenvolvimento, mas, por outro, trouxe também a convicção de que as preocupações ambientais não deveriam constituir uma barreira ao desenvolvimento, e sim tornar-se parte do processo. Dentre as recomendações dessa Conferência, cabe enfatizar a implementação de um programa de educação ambiental para combater o problema.

Em junho de 1992, a questão ambiental ganha visibilidade mundial, quando mais de 35 mil pessoas se reuniram, entre elas 106 chefes de Estados, para participar da Conferência de Cúpula das Nações Unidas sobre o Meio Ambiente e Desenvolvimento (UNCED), no Rio de Janeiro, Brasil.

A UNCED adotou como estratégia de desenvolvimento a idéia de "Desenvolvimento Sustentável" inspirada no "Nosso Futuro Comum" relatório da Comissão Mundial sobre Meio Ambiente presidida por Gro Harlem Brundtland, então primeira-ministra da Noruega, em 1987. O Relatório Brundtland, como ficou conhecido, tornou-se o mais importante documento das últimas décadas sobre o futuro do planeta. 


\begin{abstract}
“Desenvolvimento Sustentável é aquele que satisfaz as necessidades das gerações presentes, sem comprometer a capacidade das gerações futuras para satisfazer suas próprias necessidades". (CMMAD 1991, p. 46)
\end{abstract}

Segundo o referido relatório, a idéia de desenvolvimento sustentável contém dois conceitos-chaves: o primeiro seria o conceito de necessidades dos pobres do planeta, que devem obter a máxima prioridade; o segundo seria a noção de limitações que o estágio da tecnologia e da organização social impõe ao meio ambiente, dificultado-o de atender às necessidades presentes e futuras (CMMAD 1991).

Dentre as estratégias de enfrentamento da questão ambiental preconizadas na ECO-92, como ficou popularmente conhecida a Conferência realizada no Rio de Janeiro, foram assinados, por diversos chefes de Estado do mundo inteiro, documentos de abrangência mundial, tais como: a Convenção do Clima, a Convenção sobre a Biodiversidade e a Agenda 21 (VIOLA 1996; SOBRAL 1997).

O desenvolvimento sustentável não pode ser entendido como uma fórmula precisa, mas sim como um princípio norteador. Após a ECO-92, vários países fazem esforços consideráveis para incluir a questão ambiental em seus programas de governo. Vários já elaboraram suas Agendas XXI nacionais, assim como muitas cidades também elaboraram suas Agendas XXI locais.

Surgidos em uma sociedade marcada por relações clientelistas e autoritárias, em um Estado totalitário-burocrático e juridicamente inoperante, a agenda e as práticas desses novos movimentos sociais romperam, no Brasil, a demanda apenas por bens e serviços necessários à sobrevivência que até então se constituía em força predominante, para incorporar as lutas por direitos sociais modernos, como igualdade e liberdade, representando ainda a possibilidade de uma sociedade democrática. Em âmbito nacional esses movimentos manifestavam-se, num primeiro momento, principalmente em prol de melhorias de qualidade de vida, por meio de lutas pelo saneamento básico, urbanização de bairros, indo além, numa etapa posterior, para questões que envolviam os direitos sociais. Mais especificamente na área da saúde, também foi nesse contexto que surgiram os movimentos populares por saúde e saneamento, assim como o movimento pela reforma sanitária. 
Dentre esses "novos movimentos sociais", que ganharam expressão no cenário político nacional, estavam o movimento pela anistia, o movimento nacional contra a carestia, o movimento das "Diretas-Já", assim como os ambientalistas, étnicos e por direitos humanos.

Segundo ARRUDA (1995), foi também na esteira desses movimentos libertários e contestadores da década de 1960 que entraram em cena os movimentos ambientalistas, em reação à energia nuclear com o revigoramento do pacifismo, no qual mais uma vez a presença feminina teve papel relevante. "A questão ambiental começa a insinuar-se por diversas frestas. E em alguns anos não deixará insensiveis os novos movimentos sociais, constituindo-se ela mesma, numa vasta corrente" (ARRUDA 1995).

Uma das maiores referências do movimento ambientalista brasileiro foi a publicação do "Fim do Futuro? Manifesto Ecológico Brasileiro", escrito por José Lutzenberg em 1975. Este ambientalista brasileiro, que nos primeiros anos de sua vida profissional havia atuado com tecnologias de defensivos agrícolas como forma de assegurar maior produtividade agrícola e garantir abastecimento alimentar no processo de emergência de uma sociedade urbanizada, transformou sua postura dedicando-se seus esforços, posteriormente, à defesa do desenvolvimento sustentável, principalmente na agricultura e no uso dos recursos não renováveis, procurando alertar para os perigos que a globalização, nas suas tendências atuais, representava para a humanidade em âmbito ecológico e social, produzindo um importante trabalho em defesa da causa ambiental, com repercussões em escala mundial.

\subsection{Dos conceitos de representação social, sentidos e significados}

Émile Dürkheim, na área das ciências sociais, foi o primeiro autor a usar o conceito de representações sociais, que tinha o mesmo significado de representações coletivas, para se referir a categorias de pensamento por meio das quais uma determinada sociedade elabora e expressa sua realidade. Considerado como um dos fundadores da Sociologia, o autor discutiu a importância das representações dentro 
de uma coletividade, e a forma como elas influem nas decisões que os seres humanos tomam individualmente. Ainda de acordo com DÜRKHEIM (1968) a consciência coletiva transcende à consciência individual como uma força coercitiva e que pode ser visualizada nos mitos, na religião, nas crenças e nos demais produtos culturais coletivos.

Em 1961, Serge Moscovici, no campo da psicologia social, ao desenvolver a pesquisa "Representações Sociais da Psicanálise" utilizou-se do conceito de representações sociais como uma importante ferramenta para ter acesso às concepções, às visões de mundo e às percepções de uma dada sociedade, inaugurando assim, a Teoria das Representações Sociais (MOSCOVICI 1978).

Na construção da teoria, Moscovici partiu do pressuposto de que não havia um corte "dado" entre os planos objetivo e subjetivo, mas sim uma mediação entre estes dois pólos. Esta mediação seria realizada pelas representações sociais, consideradas como mecanismos psicológicos que permitem a construção de uma teoria explicativa do mundo.

De acordo com este autor, as representações sociais são modalidades de conhecimento particular que circulam no dia-a-dia e que têm como função a comunicação entre os individuos, criando informações e familiarizando-os com o que lhes é estranho, de acordo com categorias de sua cultura, por meio dos processos de ancoragem e da objetivação. Ancoragem é o processo de assimilação de novas informações, sejam idéias, acontecimentos, relações, a um conteúdo cognitivoemocional preexistente; e objetivação é a transformação de um conceito abstrato em algo tangivel (MOSCOVICI 1979).

"La representación es uma modalidad particular del conocimiento, cuya funcion es la elaboración de los comportamientos y la comunicación entre los individuos. La representación es um corpus organizado de conocimientos y una de las actividades psiquicas gracias a las cuales los hombres hacem inteligible la realidad fisica y social, se integran en un grupo o en una relación cotidiana de intercambios, liberan los poderes de su imaginación" (MOSCOVICI 1979, p.17-18). 
Nos anos 1980, o conceito solidificou-se, passando a ser referência quase que obrigatória nos estudos sobre temas contemporâneos para diversas outras áreas das ciências sociais e da saúde pública e coletiva, como pode ser constatado em trabalhos de historiadores, sociólogos, economistas, antropólogos e sanitaristas, confirmando a importância da temática análise dos fenômenos sociais. Denise Jodelet, Herzlich, Robert Farr, Wagner e Abric são alguns dos pesquisadores que vêm aprofundando a teoria desenvolvida por Moscovici.

De acordo com a teoria desenvolvida por MOSCOVICI, para dar conta das relações informais e mais cotidianas da vida humana, em nível mais coletivo ou social, é importante considerar tanto os comportamentos individuais quanto os fatos sociais, como por exemplo, as instituições e as práticas em sua concretude e singularidade histórica. O que se percebe é uma via de mão dupla, importando não só a influência unidirecional dos contextos sociais sobre os comportamentos, estados e processos individuais, mas também a participação destes na construção das próprias realidades sociais (SÁ 1993).

Diversos autores vêm explorando os vários ângulos de utilização do conceito de representação social, visando, com isto, avançar em seus objetos de estudo. Dentre esses autores está o sociólogo francês Pierre Bourdieu, que desenvolveu o conceito de "habitus" para o aprofundamento das representações sociais.

Para ele, o "habitus" é um "sistema de disposiçôes duráveis, estruturas estruturadas predispostas a funcionarem como estruturas estruturantes; isto é, como principio que gera e estrutura as práticas e as representações que podem ser objetivamente regulamentadas e reguladas sem que por isso sejam o produto de obediência de regras; objetivamente adaptadas a um fim, sem que se tenha necessidade da projeção consciente deste fim ou do dominio das operações para atingi-lo, mas sendo, ao mesmo tempo, coletivamente orquestradas sem serem o produto da ação organizadora de nenhum maestro" (BOURDIEU 1983, p.46-81).

A noção de "habitus" implica no reconhecimento de que as práticas não se dão num "vazio" e também não estão relacionadas apenas a estímulos do meio ambiente, uma vez que existe uma interferência da estrutura da sociedade sobre os 
individuos que a compõem. Da mesma forma, para o autor, as diferenças não podem ser entendidas apenas como uma questão de "relativização cultural"

No campo da antropologia, GODELIER (1981) ressaltou a importância de trabalhos que desvelem o sistema de representações sociais que os individuos e os grupos, membros de uma determinada sociedade, formulam sobre o seu meio, "....pois é a partir destas representações que os individuos ou os grupos atuam sobre o meio". Para exemplificar essa constatação Godelier relata um exemplo significativo de representações opostas, formuladas a partir do mesmo meio pelos pigmeus Mbuti, caçadores-coletores, e pelos Banto, agricultores-caçadores, grupos estes que vivem na selva equatorial africana do Congo.

"Para os pigmeus, a selva representa uma realidade amistosa, hospitaleira, benfeitora para os homens e para eles. Consideramna como uma realidade protetora dentro da qual se sentem seguros em qualquer parte. Opõem-se a selva aos espaços cultivados pelos Bantos, que lhes aparecem como um mundo hostil onde o calor é sufocante, ou a água está poluida e mortifera, ou onde as enfermidades são múltiplas. Para os Bantos, ao contrário, a selva é a realidade hostil, inóspita e mortifera, no interior da qual raramente se aventuram e sempre com muitos riscos. Consideramna povoada de demônios e de espiritos malignos dos quais os pigmeus são, senão a encarnação, pelo menos seus representantes" (GODELIER 1981, p. 53-54).

O exemplo apresentado por Godelier permite inferir que a representação social de um fato não consta, unicamente, daquelas engendradas com base na realidade objetiva e concreta, mas que está igualmente composta de juízos de valor e de crenças fantasmáticas. Para o autor, o meio tem sempre dimensões imaginárias que, em alguns casos, pode ser o lugar da existência dos mortos, ou a morada de forças sobrenaturais benignas ou malignas que se supõem controladoras das condições de reprodução da natureza e da sociedade. "Tais representações dão sentido a certos comportamentos e a intervenções sobre a natureza que para um 
observador ocidental podem parecer totalmente irracionais" (GODELIER 1981, p. $55)$.

LAPLANTINE (1991), ainda no campo da antropologia, define representações sociais como produções simbólicas que “....são simultaneamente produções sociais que sempre decorrem de práticas sociais....". Ainda segundo esse autor, ao analisar as representações sobre a doença e a cura, numa mesma sociedade, em um certo momento de sua história, as correntes médicas, os sistemas de pensamento, as escolas e os comportamentos sociais são extremamente variados e, a essas variações sociais acrescentam-se as variações individuais. A partir desta constatação, Laplantine busca, então, identificar os modelos existentes, acabando por ordená-los em modelos etiológicos que, segundo ele, vão determinar os modelos terapêuticos adotados por diferentes parcelas da população.

A coexistência de diferentes representações sobre a problemática socioambiental e sobre o processo saúde-doença, numa dada sociedade, em um dado momento histórico, apresenta-se de fundamental importância, pois acredita-se que seja a partir da raiz dessas representações que os diversos comportamentos sejam adotados pelos indivíduos e pelas comunidades, inclusive na determinação da relação homem e mundo natural.

No campo da psicologia social, Denise Jodelet, destaca-se das mais importantes pesquisadoras da teoria das representações sociais na atualidade, a qual enfatiza que, na fronteira entre o psicológico, o subjetivo e o social, as representações são uma maneira de interpretar e pensar a realidade cotidiana, articulando elementos afetivos, mentais e sociais e integrando, ao lado da cognição, da linguagem e da comunicação, a realidade material, social e ideal sobre as quais essas representações vão intervir (JODELET 1983).

No Brasil, no que se refere à problemática ambiental dentro da perspectiva das representações, podemos citar estudos como os de ARRUDA, 1995. Em sua tese de doutorado, essa autora desenvolveu uma investigação sobre as representações sociais de grupos de ecologistas e ecofeministas na cidade do Rio de Janeiro. 
CRESPO \& LEITÃO (1992) realizaram duas extensas pesquisas de opinião a respeito da relação dos brasileiros com a ecologia, que lhes permitiu traçar uma tipologia destas formas de relação, estabelecendo tipos de público diferentes para as questões ambientais, segundo seu envolvimento e nivel de informação.

Ainda dentre os autores brasileiros que vêm aprofundando e contribuindo para o desenvolvimento de estudos sobre a questão ambiental, a partir da perspectiva das representações sociais, podem ser mencionados REIGOTA $(1995,1998,1999)$ e KUHNEN (2002).

A partir do que já foi esboçado até então, cabe ressaltar que, embora, na elaboração da presente tese, a princípio, tenha se adotado como referencial teórico, unicamente, as representações sociais a partir do enfoque da psicologia social, no decorrer da investigação, percebeu-se que haveria necessidade de se agregar outros conceitos e outros referenciais teóricos que permitiriam à pesquisadora chegar o mais próximo possível da problemática estudada, agregando tanto aspectos mais subjetivos como aspectos macroestruturais. Para tanto, adotou-se os conceitos de representações, sentidos e significados, dentro de uma perspectiva construcionista apoiando-se em teóricos tanto da sociologia como da psicologia social, buscando outros aportes ainda de outras áreas do conhecimento, como ver-se-á mais adiante.

Acredita-se ainda, que as idéias e os conceitos não sejam incorporados de modo uniforme pela sociedade, mas sim a partir da classe ou do contexto social a que o sujeito se identifica. Assim, as representações passam a não ser somente as representações individuais, mas fundamentalmente, as manifestações próprias de cada classe ou grupo de referência em uma dada sociedade.

\subsection{Trocando olhares: os aportes multidisciplinares na compreensão da problemática socioambiental}

Pensar a questão ambiental na contemporaneidade, no campo das ciências sociais, é um desafio para pesquisadores da área. Nesse sentido, tem se mostrado necessário, aos cientistas sociais, ampliar os horizontes para referências formuladas em outros campos disciplinares. Especialmente no que se refere à questão ambiental, 
uma vez que o tema encerra dificuldades diversas ligadas ao entrelaçamento de aportes de diferentes disciplinas ou especialidades técnicas e teóricas.

Há que se ampliar o olhar para análises interdisciplinares atentando para os riscos existentes pois, na busca da interdisciplinaridade muitos acabam por unificar os discursos científicos, homogeneizando suas estruturas conceituais dentro de explicações biologistas dos processos históricos (LEFF 2001).

Moraes (1998), ao abordar a questão da interdisciplinaridade no estudo da questão ambiental, traz a tona o risco do que ele denomina "naturalismo", isto é, posturas que tomam a problemática ambiental somente no seu aspecto biológico e natural, deixando de lado a dimensão social que o tema encerra.

"Tratam daqueles discursos que vêem o homem apenas como fator de alteração do equilíbrio de um meio; daquelas análises que não falam de sociedade, mas apenas da ação antrópica, uma variável a mais num conjunto de fatores basicamente naturais; a relação homem-natureza, assim, sendo concebida sem a mediação das relações sociais". (MORAES 1998).

Diante destas considerações entende-se que, ao refletir e conceituar a problemática socioambiental, faz-se necessário contextualizá-la geopoliticamente, mundializá-la e adjetivá-la, integrando-a na lógica da industrialização e da globalização ora em decurso. Acredita-se que este seja o caminho para introduzir neste trabalho, as possibilidades que os conceitos provenientes de campos disciplinares e orientações epistemológicas diferentes e aparentemente distantes podem oferecer. Aproximações com autores de outras áreas, como a antropologia a geografia e a sociologia urbana, a economia política e a psicologia social oferecem subsídios que permitem a elaboração de argumentos a favor de uma postura sobre a produção do conhecimento, entendida como produções parciais, locais e posicionadas, em contraposição à produção do conhecimento neutra e não comprometida com o processo de construção, interpretação e mudança dos fenômenos sociais, baseada na compreensão da realidade como algo externo, 
susceptível de ser captada na sua 'totalidade' por meio de procedimentos de generalização e simplificação dos fenômenos sociais (GARCIA 2004).

A contribuição da Antropologia Crítica, que tem no antropólogo CLIFFORD GEERTZ um dos seus maiores expoentes, traz para a análise dos fenômenos sociais uma maneira de entender a pesquisa como um processo reflexivo que questiona os próprios pressupostos culturais, ao entendê-la como um encontro negociado a partir das posições assumidas tanto pelo pesquisador como por aqueles com os quais ele se relaciona (GEERTZ 2001).

As transformações ocorridas no mundo a partir dos anos 1960, incluindo desde os movimentos de descolonização, os movimentos de direitos civis até o surgimento da economia globalizada provocaram, no âmbito das ciências sociais, profundas mudanças nas suas concepções sobre o objeto de análise, a linguagem da análise e a posição do pesquisador. Para GEERTZ (2001), os cientistas sociais têm desviado, cada vez mais, a atenção de explicações embasadas em leis gerais, atentando para estudos de casos e sua interpretação. Este autor argumenta que os pressupostos objetivistas sobre a produção da teoria, a linguagem e a postura do pesquisador neutro, não se sustentam mais, devido à mudança da agenda social.

O conceito "saber local" proveniente do movimento critico na Antropologia Cultural e proposto pelo antropólogo Clifford Geertz, alinha-se dentre os conceitos mais relevantes para o entendimento da produção de conhecimentos a partir de análises mais contextualizadas. Ao introduzir esse conceito, o autor chama a atenção da comunidade científica para a importância dada pela antropologia cultural ao estudo interpretativo das culturas, na busca de reconhecer a diversidade de modos que os seres humanos utilizam ao construírem suas vidas, no processo de vivê-las e ao institucionalizar suas vivências em práticas culturais (GARCIA 2004).

Em estudos de aprofundamento sobre o conceito saber local, GEERTZ (2001) corrobora a importância da opção por esta perspectiva apoiando-se no que ele denomina de hermenêutica social, ou seja, "o entendimento do entendimento". $O$ autor apóia-se na necessidade do abandono de explicações de fenômenos sociais por meio de uma metodologia que os tece em grandes redes de causas e efeitos, e, propõe tentar explicá-los em estruturas locais de saber (GARCIA 2004). 
Um outro elemento que se destaca na reflexão proposta por GEERTZ (2001) é a produção do conhecimento a partir da idéia de lugar. Quando propõe olhar para as estruturas locais de saber, embora pareça que ainda persista a preocupação com as formas institucionalizadas desse saber, este autor abre uma janela para a relevância do lugar. Isto possibilita resgatar essa visão ampliando-a para pensar o papel do lugar como local-particular, na estruturação de saberes e posições de pessoas em interação.

Decorrente disso, surge na esteira do movimento da antropologia crítica, também no campo das ciências sociais, um paradigma emergente nas investigações, marcado por interesses mais centrados em contextos históricos e políticos, cujas análises voltam-se para aspirações e demandas de grupos freqüentemente nomeados como marginais, fortemente influenciado pelos movimentos da contracultura, como o ambientalismo, o feminismo, os movimentos "gays", os movimentos dos indígenas, a luta dos negros e os das minorias raciais, em situações de desigualdade e opressão; em fatores como a ocidentalização, o imperialismo midiático, a invasão da cultura material. Deste modo, a reorientação da antropologia e das ciências sociais como um todo, fez parte de uma dinâmica maior de movimentos sociais e reformulações intelectuais (SANTOS BS 1995 ).

Essa visão mais ampliada sobre o saber local sobre a relevância do lugar permite que se estabeleça uma ponte entre as propostas tanto da antropologia, das ciências sociais e as da geografia, especialmente ao se apoiar nos estudos de SANTOS M (1997). Este autor, ao discorrer sobre "A Urbanização Brasileira", ressalta a importância de circunscrever o fenômeno, identificar sua especificidade, mensurar sua problemática, para conseguir uma interpretação abrangente, embora o próprio autor considere que nenhuma ciência pode oferecer a representatividade completa do conhecimento. Para SANTOS M (1997), só a conjunção das ciências econômicas, sociais, políticas e outras é que poderá dar conta da realidade em estudo.

Para tanto, SANTOS M (1997) traz também para o debate o conceito que destaca como relevante para a reflexão a respeito da produção de conhecimentos sobre a questão ambiental, na atualidade, que é o conceito de "espaço e o de lugar". A história de nosso tempo recoloca a questão do lugar numa posição central, 
conforme vem sendo assinalado por inúmeros estudiosos, o que fez tão brilhantemente SANTOS M (1997) em sua obra "A Natureza do Espaço".

A partir dessas premissas, considera-se o ambiente como a organização humana no espaço total, que por sua vez, compreende os fragmentos territoriais em todas as suas camadas e dimensões. Nesse sentido, trata-se de uma visão sistêmica e abrangente que permite tanto observar a particularidade quanto o geral, o local e o global (TASSARA 2001; RABINOVICH \& GOUBERT 2003).

Segundo SANTOS M (1997), impõe-se a necessidade de revisitar o lugar no mundo atual, conhecer seu cotidiano, a fim de encontrar novos significados. Globalização e fragmentação; globalização e localização fazem parte de uma realidade tensa, instável, na qual a dialética se refaz com freqüência e com muita velocidade. Todos os lugares são virtualmente mundiais, porém cada lugar, imerso numa comunhão com o mundo, traz em si uma diversidade própria que o faz diferente de todos os outros (SANTOS M 1997).

De acordo com essa perspectiva, nos processos de interpretação os pesquisadores também são sujeitos posicionados num contexto particular, e se autoreposicionam na medida que vivem, eles mesmos a experiência da compreensão de outras culturas e de outras formas de construção social da realidade. Os investigadores começariam assim suas pesquisas com uma serie de questionamentos, que à luz do processo da investigação para, no final, desembocarem em perguntas que não tinham sido consideradas no início. Esse movimento constante de respostas recebidas, reflexividade e negociação de sentidos, se constitui como parte importante da postura defendida por diversos cientistas sociais e psicólogos sociais de linha construcionista (GARCIA 2004).

Fazendo uma ponte com outras áreas da ciência, aparentemente distantes, a questão referente ao saber local e ao poder local também tem sido alvo do questionamento dentro do campo da economia política. DOWBOR (1999) enfatiza que o conceito de espaço, sobretudo aquele em que acontece a reprodução social ${ }^{7}$, no

\footnotetext{
${ }^{7}$ Reprodução social se contrapõe à reprodução do capital. Reprodução do capital refere-se, essencialmente, ao processo de crescimento econômico centrado nas atividades produtivas. Reprodução social é mais amplo: define tanto a produção como os serviços sociais e as diversas
} 
processo de desenvolvimento, vem gerando diversos questionamentos sobre as questões presentes na sociedade contemporânea.

Para DOWBOR, a simples reprodução do capital ou reprodução econômica já não é suficientemente abrangente para refletir os problemas decorrentes da globalização, da constituição dos blocos econômicos e políticos, inclusive para entender a própria reprodução do capital.

Para tanto, este autor traz ao cenário das discussões o conceito de reordenamento dos espaços, uma vez que conceitos como "globalização", na visão deste, imprimem uma visão simplificada de abertura e unificação dos espaços da reprodução social. Na concepção de DOWBOR (1999) o que vem ocorrendo é uma nova hierarquização dos espaços, de acordo com diferentes atividades, envolvendo tanto a globalização como a formação de blocos, enfraquecendo dessa maneira, o conceito de Estado-Nação e propiciando o surgimento de espaços sub-nacionais fracionados.

Mais uma pergunta parece que se faz necessária ao desenvolvimento desta tese: mas afinal, qual a importância dos argumentos oferecidos por Geertz, Boaventura Sousa Santos, Santos e Dowbor? O que é que permite, afinal, esta postura epistemológica dos conhecimentos do "saber local", "do lugar", dos conhecimentos comprometidos e engajados e do reordenamento dos espaços? $\mathrm{O}$ argumento sobre o qual se embasa esta tese considera que esse tipo de postura epistemológica introduz uma ruptura importante, não só no campo da antropologia, da geografia, da economia política, mas, sobretudo, no campo das ciências humanas como um todo, na medida que exige do próprio pesquisador uma postura crítica à autoridade científica do pesquisador, tornando-o um observador posicionado e consciente de que o processo de conhecimento é algo parcial, localizado e provisório, o que requer do investigador uma maior abertura para novas e inesperadas conexões que, porventura, possam despontar no decorrer da investigação.

Com relação ao conceito de reordenamento dos espaços entende-se, como já colocado em capítulo anterior que, embora as representações, os sentidos e os 
significados que as pessoas atribuam a um fato sejam de fundamental importância para o entendimento do mesmo, acredita-se também, que o substrato macroestrutural ligado ao modo de produção de uma determinada sociedade, no caso, o modo de produção capitalista, tenha uma influência decisiva na maneira como são formadas essas representações, sentidos e significados. 


\section{CAPÍTULO 2}

O PROCESSO DE URBANIZAÇÃO E O AMBIENTE:

RISCOS À SAÚDE 


\subsection{O processo de urbanização e a problemática socioambiental}

Inicia-se este capítulo enfatizando que, na sociedade contemporânea, a inserção da problemática urbana nos debates torna-se necessária e essencial para a compreensão da interface entre saúde e meio ambiente.

Os temas urbanização, ambiente e saúde sempre estiveram presentes nas investigações de diversos estudiosos, desde o início da formação das cidades modernas. Porém, o que parece demarcar a expansão dos estudos em direção à "problemática urbana", especialmente entre aqueles pesquisadores oriundos da corrente marxista, é o processo de industrialização.

LEFEBVRE (2001) constrói uma instigante discussão sobre a "problemática urbana". Para este autor, o ponto de partida será sempre o processo de industrialização, mesmo que a cidade tenha preexistido à industrialização.

De acordo com LEFEBVRE (2001), a industrialização seria o indutor do processo de urbanização. Dessa maneira, a urbanização e todos os problemas decorrentes são os efeitos induzidos pela industrialização. A industrialização e a urbanização constituem-se, assim, nos marcos mais emblemáticos da sociedade contemporânea.

FOUCAULT (1979) em "O nascimento da medicina social”, demonstra que a industrialização provocou e ampliou a urbanização que, por sua vez, induziu à "problemática sanitária", contribuindo, desse modo, ao surgimento da moderna Saúde Pública; ROSEN (1994) em "Uma História da Saúde Pública", demonstra esta mesma interrelação. Nesse sentido, a Saúde Pública, como campo de saber, pode ser considerada como produto da urbanização.

Em seu livro, ROSEN (1994) traça um minucioso panorama da evolução urbano-industrial em conjunto com a Saúde Pública, demonstrando que os maiores problemas de Saúde Pública sempre estiveram ligados à história da vida em sociedade da espécie humana. Dessa forma, pode-se afirmar que a prática sanitária prender-se sempre à estrutura econômico-social de cada época, o que demonstra a historicidade dos saberes e das práticas nas ciências da saúde em geral (COELHO 1998). 
Cabe trazer a discussão, acerca da questão da urbanização no contexto contemporâneo, o conceito de espaço. Autores como SANTOS M (1997), LEFEBVRE (2001) E GOTTDIENER (1993), quando se referem ao processo de urbanização, trazem à tona a discussão acerca do significado do espaço advertindo para a multiplicidade de sentidos e para a natureza multifacetada do termo.

De acordo com SANTOS M. (1979), “O espaço é a matéria trabalhada por excelência. Nenhum dos objetos sociais tem uma tamanha imposição sobre o homem, nenhum está tão presente no cotidiano dos indivíduos. A casa, o lugar de trabalho, os pontos de encontro, os caminhos que unem esses pontos são, igualmente, elementos passivos que condicionam a atividade dos homens e comandam a prática social".

O espaço é, ao mesmo tempo, uma localização física - o local geográfico, e um meio de produção - a terra. Portanto, o espaço faz parte do conjunto das forças sociais de produção, cada vez mais instrumentalizado e urbanizado: nesse sentido, é um produto material dentro de uma dada formação social, e tem a mesma importância ontológica do trabalho e do capital, tomando como referência, o modo de produção capitalista.

Para SANTOS M (1997), o espaço como algo dinâmico e unitário é “o conjunto indissociável de sistemas e objetos naturais ou fabricados e de sistemas de ações deliberadas ou não". As relações sócio-espaciais ali estabelecidas são marcadas por contradições e conflitos.

A teoria da produção do espaço de LEFEBVRE (2001) afirma que a relação espaço-sociedade permite que, por meio do espaço produzido ou do ambiente construído, chegue-se à compreensão da origem e do desenvolvimento da sociedade atual. O espaço é um produto social e de relações sociais que estabelece uma relação dialética cujo produto - o espaço produzido ou trabalho morto - é transformado em produtor, contribuindo dessa forma, para a acumulação do capital (GOTTDIENER 1993).

Nessa linha de pensamento, o espaço é que confere importância ao Estado, no momento que este é o instrumento político de controle e administrativo. Cabe destacar que, após a Segunda Guerra Mundial o papel do Estado se acentuaria, 
sobremaneira, em decorrência do advento do capitalismo monopolista de Estado, mediante as políticas keinesianas de regulação e controle, planejamento econômico e urbano, investimentos industriais, programas de previdência social.

Diversos autores vêm apontando para o processo intenso de urbanização como um dos principais problemas ambientais da América Latina. É nas grandes cidades que a qualidade de vida da população encontra-se mais prejudicada pelas dificuldades de transporte urbano, pela degradação do meio ambiente natural, pela poluição do ar, pela contaminação das águas, pela falta de moradia, pelo crescente desemprego, por agravos à saúde pública causados pela propagação de doenças infecto-contagiosas, enfim, por muitos fatores resultantes do ritmo frenético de urbanização ocorrido em todo o continente (HOGAN 1995; JACOBI 1996; LEFF 2001).

No caso brasileiro, em especial na cidade de São Paulo, foi nesse periodo do pós-guerra que se iniciaram muitos dos problemas urbanos que perduram até os dias atuais, principalmente no que se refere à ocupação desordenada dos espaços. A crise habitacional instalada, na época, em decorrência do intenso êxodo rural, vai marcar todo o processo de desenvolvimento urbano da cidade, trazendo conseqüencias nefastas ao ambiente natural e construido, com reflexos à saúde humana.

As preocupações com o ritmo frenético do processo de urbanização e seu impacto sobre a qualidade de vida nas cidades vêm suscitando questionamentos generalizados, tanto por parte dos administradores públicos, quanto pela comunidade científica e pela sociedade civil. As Conferências HABITAT I realizada em Vancouver, Canadá (1975) e a HABITAT II realizada em Istambul, Turquia (1996), são exemplos disso.

Cabe destacar a análise feita por ROLNIK \& SAULE JÚNIOR (1996) sobre o tema global da HABITAT II - Assentamentos humanos, com base nos vintes anos decorridos desde a HABITAT I: 
“... A dimensão dos problemas urbanos e a própria urbanização acelerada de todo o planeta foi, ao longo desses vinte anos, trazendo para o Habitat novas questões: a irregularidade e precariedade dos assentamentos populares em todo o mundo pobre, necessidade de expansão das infra-estruturas e dos serviços urbanos, a nova escala dos problemas de transportes $\mathrm{e}$ acessibilidades, o armazenamento, abastecimento e utilização de energia e água, o controle e tratamento de resíduos, a poluição ambiental, atmosférica e sonora, a degradação ambiental decorrente da própria expansão urbana, o crescimento da pobreza, da falta de empregos e de renda, o aumento de violência, o acirramento dos conflitos de terra e despejos ilegais".

(ROLNIK \& SAULE JUNIOR 1996).

Além dos problemas citados por ROLNIK \& SAULE JUNIOR (1996) é importante lembrar que, especialmente a partir das duas últimas décadas do Século $\mathrm{XXI}$, grandes e várias aglomerações populacionais desenvolveram-se junto a instalações industriais de alto risco, dutos ou depósitos de produtos perigosos, ou ainda junto a vias urbanas e estradas por onde transitam cargas perigosas. Juntamente com as situações de ameaças de deslizamentos, tais situações fazem com que os acidentes ambientais representem um potencial de sérias conseqüências sobre a saúde e a vida das populações.

Já o risco de desastres lentos, acidentes nucleares, contaminações profundas dos sítios de lixões clandestinos e das suas áreas circunvizinhas, sequer é plenamente conhecido, o que justifica pesquisas urgentes que o desvelem para a população (CUNHA 1996; REIGOTA 1995).

Em relação ao Brasil e à sua dinâmica econômica e demográfica, a crescente globalização, aliada ao ritmo acelerado de urbanização verificado nas últimas décadas, tem contribuído para um transbordamento das atividades industriais da metrópole para um raio mais amplo, causando grande crescimento das cidades 
médias, situadas ao redor de pólos regionais de desenvolvimento, processo este que vem tendo um impacto ambiental ainda não avaliado (SOBRAL 1992).

Concomitantemente ao processo de transbordamento das atividades industriais vem ocorrendo, há décadas, um processo de expulsão de populações do meio rural, devido a uma intensa concentração fundiária, o que está acarretando formas de ocupação e uso do solo urbano sem planejamento adequado, tanto nas periferias dos grandes centros, quanto em cidades pequenas e médias.

Por esse motivo verifica-se forte pressão de órgãos e entidades ambientalistas no sentido de exigir um maior conhecimento da dinâmica ambiental urbana, como forma de assegurar melhor qualidade de vida. Esta pressão tem levado a um deslocamento da agenda ambiental de ecossistemas "naturais", como Mata Atlântica, manguezais e animais em extinção, para questões urbanas, tais como saneamento urbano, drenagem urbana, recursos hídricos, poluição atmosférica, disposição final adequada de resíduos sólidos, ocupação desordenada de áreas de proteção ambiental, entre outras (KRASILCHIK 1996).

Um ponto em comum existente entre os teóricos que vêm tratando a questão da problemática ambiental é que a relação urbanização, ambiente e saúde está cada vez mais visível no cotidiano da população urbana, principalmente nas grandes metrópoles, devido à dinâmica predatória da urbanização, à falta de responsabilidade e de compromisso do poder público com tais questões e, muitas vezes, da própria população.

No que se refere à saúde pública, que tem como uma de suas características o conhecimento multidisciplinar, este processo de globalização pelo qual a sociedade, está se tornando cada vez mais complexa e se fragmentando de forma crescente e contínua, vem acarretando significativas mudanças. Novos cenários, novos desafios e novas questões surgem, ao lado das antigas contradições e velhos problemas, para serem desvendadas e discutidas e equacionadas, por vezes em caráter emergencial e de forma curativa.

A par dos grandes desafios a serem enfrentados pela Saúde Pública neste milênio, tais como as chamadas doenças da pobreza (respiratórias e infecciosas/parasitárias), diretamente relacionadas a condições ambientais, citados 
por HOGAN (1995), deve-se reunir forças para enfrentar os chamados "problemas emergentes de saúde pública", assim considerados tanto por não serem abordados anteriormente,quanto por não existirem antes, ao menos nas proporções atuais.

Dentre estes problemas emergentes pode-se citar a Aids, a drogadição, a violência urbana, o sedentarismo e a obesidade. A mudança do perfil demográfico, referente ao aumento do contingente populacional das faixas etárias mais avançadas, também vem provocando mudança nos padrões de mortalidade e morbidade, fazendo com que as cidades brasileiras sofram, simultaneamente, problemas característicos de países desenvolvidos e subdesenvolvidos (HOGAN 1995).

Nesse sentido, um aspecto que pode ser tomado como fenômeno heurístico do processo em de urbanização interrelacionado à problemática ambiental, refere-se ameaças à saúde e à vida, que vem se apresentando como problema global, assim como as estratégias de enfrentamento e intervenção dessas questões.

Pode-se afirmar que as ameaças à vida decorrem não só das doenças e das chamadas causas externas, como os homicídios e acidentes, mas também da possibilidade de extinção, aniquilamento e deterioração dos recursos ambientais.

Cada vez mais se reconhecem os impactos dos determinantes sociais e dos fatores ambientais na saúde e na qualidade de vida das mulheres, dos homens e das comunidades. Os problemas ambientais que afetam a saúde pública não são atuais como parecem: desde a Antigüidade a deterioração do meio ambiente já se fazia presente, porém nos tempos atuais é presenciada a emergência de novos problemas cada vez mais profundos e complexos, sem que tenham sido solucionados aqueles que já afetavam a humanidade há décadas.

Da alimentação à poluição atmosférica, da saúde no trabalho ao estresse metropolitano, da violência no trânsito à qualidade de vida nas cidades, do saneamento ambiental ao uso indiscriminado de agrotóxicos na agricultura, a relação entre saúde e meio ambiente é palco para discussões, tanto no plano das políticas públicas e experiências locais, quanto no dos diagnósticos e estratégias internacionais (JACOBI 1996).

Dada a precariedade da ação do Estado na proteção e na preservação de danos ao ambiente, cuja atuação, por não assegurar um nivel adequado de condições de 
vida, acaba por favorecer a ocorrência de impactos profundos sobre a saúde das populações urbanas, a conexão saúde e meio ambiente ganha concretude e expõe as contradições profundas do modelo econômico injusto e insustentável adotado pelo país (JACOBI 1996).

Depara-se, no início do Século XXI, com um quadro em que, para grande parte das populações que vivem nas cidades, a saúde torna-se uma porta de entrada para o debate ambiental, e conseqüentemente, para a qualidade de vida, seja pelos resultados nefastos causados pelas desigualdades sociais, seja pela deterioração cada vez mais acentuada do meio ambiente nas cidades. A situação ganha maior relevância se observadas as condições precárias vivenciadas pelas populações de cortiços, favelas e moradias de bairros periféricos, no caso de São Paulo (JACOBI 1996; MARICATO 2001) e os grandes problemas ambientais, tais como erosões, contaminações de solo e de rios causadas por agrotóxicos, com os quais se deparam os pequenos e médios municípios rurais brasileiros (HOGAN 1995).

SPOSATI (1996) apresenta também um panorama bastante negativo em seu trabalho "Mapa da exclusão social". Para esta autora, ressalta-se, dentre os múltiplos problemas da cidade de São Paulo, a profunda desigualdade social acarretando problemas de ordens diversas, tais como violência, degradação ambiental, aumento da população favelada, problemas de saúde, explosão de cortiços nas áreas centrais da cidade, dentre outros.

Por outro lado, em outras áreas geográficas da cidade formam-se ilhas de riquezas, onde se concentram casas luxuosas, prédios de alto-padrão e oferta de consumo variado e sofisticado. Essas ilhas de primeiro mundo expressam "símbolos de status" e reforçam processos de distanciamento social pela afirmação de diferenças e desigualdades sociais. 


\subsection{Segregação urbana e os espaços de pobreza: os loteamentos irregulares na cidade de São Paulo}

O debate acadêmico e político no Brasil acerca do tema da segregação nas grandes cidades tem na ilegalidade urbana um dos parâmetros centrais na definição das clivagens socioespaciais postas em discussão.

GROSTEIN (1987) em uma importante investigação acerca da questão do uso do solo na cidade de São Paulo, destacava em seu trabalho a existência de uma grande parcela da população em situação de ilegalidade da sua propriedade urbana. Em 2004, passados mais de 17 anos da publicação da obra da autora, ainda é possível encontrar, no município de São Paulo, os contornos da cidade clandestina, que apontam para um quadro ambiental de múltiplas precariedades.

Mesmo que parte dessas áreas clandestinas já se encontrem incorporadas às determinações legais e administrativas, essa mudança pouco transformou as condições de vida das populações. Arruamentos irregulares e loteamentos clandestinos não são características novas da questão urbana, mas datam das primeiras décadas do Século XX, e continuam, ainda, como grandes problemas urbanos a serem enfrentados, no início do Século XXI.

De acordo com GROSTEIN (1987), a clandestinidade e a irregularidade se consolidaram ao longo da ocupação do espaço no município de São Paulo, sendo que estas questões foram ganhando maior destaque na medida em que se acelerou o processo de urbanização. Para esta autora, as prerrogativas de controle do Estado sobre a expansão urbana não foram suficientes para que a questão da clandestinidade e da irregularidade fosse um fato evitável.

Desde as primeiras décadas do Século XX, foram sendo criadas as condições para que a clandestinidade e a irregularidade se estabelecerem como práticas de parcelamento do solo, para fins urbanos. A despeito de o município contar, desde a década de 1920, com uma legislação, em que se definiam os contornos da cidade oficial, a partir da década de 1930 houve uma aceleração do processo de capitalização e estocagem do solo para exploração comercial e especulação imobiliária, provocando com isso, aceleração do processo de ocupação irregular em encostas, áreas de proteção ambiental, proximidades de atividades industriais 
poluentes, e outras, levando contingentes expressivos de população urbana a buscar áreas não disputadas comercialmente (GROSTEIN 1987; BONDUKI 1998; MARICATO 2001).

A partir da década de 1930, a clandestinidade e a irregularidade produziram arruamentos e abertura de loteamentos clandestinos. Cabe destacar que, embora muitos loteamentos fossem destinados à população de elevado nível de renda, especialmente aqueles situados ao redor das represas Billings e Guarapiranga, a maioria deles seria ocupada pela população de baixa renda.

A história testemunha que, desde a gênese do processo de expansão urbana da cidade de São Paulo, a aplicação das normas urbanísticas sugeria uma determinada forma de fugir aos controles, o que GROSTEIN (1987) denomina de "rito da desobediência".

Entres os fatores que contribuíram para essa desobediência, o fato de a lei permitir a abertura de vias públicas e de vias privadas aponta o caminho para o não cumprimento das normas.

Entretanto, os efeitos desses procedimentos não são imediatos. São precisos anos de expansão urbana e de ocupação efetiva dessas áreas - que vinham sendo arruadas e loteadas sem ocupação - para que tornasse evidente o seu estado de abandono. Abertas inicialmente para permanecerem sob o domínio dos que as abriram, paulatinamente tornam-se pelo uso um bem público, sem de fato o serem (GROSTEIN 1987).

Ademais, com a conservação dessa situação ambígua, o Estado tinha justificativas necessárias para não viabilizar recursos públicos para essas áreas. Nesse sentido, a ocupação urbana fugia ao controle estatal sem que isso, inicialmente, constituísse um problema para o Estado equacionar (GROSTEIN 1987).

Em sua tese de doutoramento, GROSTEIN (1987) concluirá seu trabalho argumentando que esse modelo de assentamento apresentava sinais de haver se esgotado, por fatores de ordem econômica, social e política. $\mathrm{Na}$ época, a autora 
defendia que havia uma intenção de um controle efetivo, assumido pelo Estado, sobre as áreas de expansão urbana.

Contrapondo-se à idéia de colocar a ilegalidade como parâmetro central nos debates acerca das clivagens socioespaciais, LAGO (2003) faz um instigante questionamento às abordagens dualistas hegemônicas da realidade urbana, tais como: formal-informal; centro-periferia; integrado-excluído; favela-bairro. Para esta autora, em todas essas dicotomias, a (i)legalidade está presente como um dos critérios diferenciadores.

Referindo-se às limitações contidas nessa abordagem, LAGO (2003), enfatiza o reducionismo presente no debate em questão, que se apóia na relação, quase inexorável, da ilegalidade com a pobreza urbana, sendo que a ilegalidade das camadas médias e altas nem sequer tem sido problematizada pelas forças progressivas, desde a Constituição de 1988. De acordo com essa autora, o princípio da integração dos excluidos vem orientando parte significativa do novo aparato legalinstitucional, em detrimento do princípio redistributivo.

A idéia proposta por LAGO (2003) é de que a crítica às limitações e aos princípios que norteiam as politicas urbanas deva ser acompanhada de uma reconceituação dos termos que expressam a ilegalidade urbana, especialmente dos termos, "favela" e "loteamentos clandestinos", à luz das diferentes lógicas de produção desses espaços e das formas de acesso à cidade.

A despeito das controvérsias, o que se assiste ainda hoje, no município de São Paulo, é uma proliferação de ocupações clandestinas e irregulares, não só por parte das classes menos favorecidas, mas também das classes mais abastadas, como pode ser presenciado nas margens da Represa Billings e Guarapiranga e na disputada região da Serra da Cantareira. Esse crescimento ocorreu por meio de mecanismos e estratégias de produção do espaço urbano, apoiados em rearticulações de poder e desrespeito às leis vigentes. A temática do presente estudo abarca a produção do solo urbano, em especial a formação de espaços habitacionais nas regiões periféricas de São Paulo.

Cratera da Colônia, local escolhido para a presente investigação refere-se a um exemplo de que essa questão ainda perdura no município, especialmente nas 
áreas de proteção aos mananciais, acarretando sérios riscos ambientais, não só às populações ali instaladas, mas também ao ambiente natural da região $\mathrm{e}$, conseqüentemente, ao abastecimento público de água na cidade de São Paulo.

Apoiando-se em indicadores construídos a partir de informações do Censo de 2000, o estudo de PASTERNAK (2003) sobre a situação habitacional em São Paulo, demonstra que o processo de periferização da população continua em franca expansão. Enquanto que, desde a década de 1980 as taxas de crescimento populacional nos anéis centrais vêm sendo negativas, todo o crescimento percebido aloca-se na periferia do município.

"Os moradores mais pobres são impelidos para regiões cada vez mais distantes, tanto para o entorno da capital como para as cidades limítrofes. A polarização social, visivel a olho nu, ganha novos contornos: a pobreza se espalha para todo o tecido municipal, enquanto que as classes mais abastadas se concentram em verdadeiros enclaves de riqueza, sobretudo na região sudoeste da capital. As demais camadas sociais se distribuem de forma espraiada, empobrecendo na direção da periferia" (PASTERNAK 2003).

A periferização e a pauperização da população paulistana tornam-se ainda mais visiveis ao atentar para os dados referentes aos tipos de moradia prevalentes na cidade de São Paulo. Enquanto que, no periodo de 1980 ao ano 2000, a população do município de São Paulo cresceu a uma taxa de 1,07\% anuais, a população favelada de São Paulo cresceu à taxa anual de 5,12\%, no mesmo período. (PASTERNAK 2003).

Como a área objeto de estudo desta tese encontra-se inserida numa Área de Proteção Ambiental- APA e dentro de uma Unidade de Conservação, torna-se necessário ainda um breve histórico das leis que regem a instituição da APA como instrumento de proteção e preservação dos mananciais da Região Metropolitana de São Paulo - RMSP, assim como a conceituação de Unidade de Conservação. 


\subsection{Os mananciais da Região Metropolitana de São Paulo e a legislação}

Remontam da década de 1970 as leis de proteção aos mananciais (LPM) no Estado de São Paulo. De acordo com a LPM de 1970 previam-se a restrição da ocupação urbana nessas áreas, por meio da fixação de parâmetros urbanísticos que introduzissem ocupações de baixa densidade populacional e restringissem a possibilidade da expansão das obras de infraestrutura, tais como rede de abastecimento de água, rede coletora de esgotos e equipamentos sociais urbanos, como unidades escolares e de saúde.

Passaram-se mais de trinta anos e o previsto na lei não foi implementado. Pelo contrário, a mancha urbana invadiu os limites da área de proteção aos mananciais da RMSP, por várias razões, dentre as quais pode se destacar o abandono das áreas centrais da cidade e o conseqüente adensamento das áreas mais periféricas, estimulado pela especulação imobiliária; a criação de novos pólos industriais e de serviços; e a ausência de uma política habitacional voltada para as populações menos favorecidas.

As áreas de proteção aos mananciais ocupam mais de $50 \%$ do território da RMSP e, segundo estimativas a partir dos dados do Censo 2000, a população residente nas áreas de mananciais ultrapassa a 1,6 milhões de pessoas, número este que representa, aproximadamente, $10 \%$ da população total da RMSP.

Esse quadro populacional expressivo impede qualquer possibilidade de remoção desta população, ao mesmo tempo em que exige ações no sentido de criar condições de melhoria da qualidade ambiental e de vida dos moradores dessas áreas.

Para tanto, diante da irreversibilidade do processo e com o objetivo de compatibilizar as ações de preservação dos mananciais ao uso do solo e ao desenvolvimento econômico dessas regiões, a LPM foi revista em 1997. Foi aprovada uma nova lei denominada como Lei de Proteção e Recuperação de Mananciais do Estado de São Paulo, a Lei $n^{\circ}$ 9866/97 a qual passou a vigorar para todos os mananciais do Estado de São Paulo. A novidade trazida pela nova lei consistia no fato de que, aliado ao reconhecimento da necessidade de intervenções para recuperar as áreas ocupadas e diminuir seus impactos negativos, previa-se também uma participação mais ampla dos poderes municipais e estaduais, como 
também das comunidades organizadas dessas áreas, no controle e administração dos mananciais.

Para que a gestão e a participação fossem mais adequadas aos problemas específicos de cada bacia, definiu-se que cada uma delas deveria ter uma estrutura autônoma, capaz de juntar os esforços de todos os envolvidos na preservação do meio ambiente e também em outras políticas, que pudessem interferir na questão, tais como habitação e desenvolvimento. Para alcançar seus objetivos, a Lei 9866 previa também que nas “Áreas de Proteção e Recuperação dos Mananciais” - APRMs deviam ser criadas “Áreas de Intervenção". Além das normas ambientais, urbanísticas e de saneamento, outras ações e obras deviam ser feitas para proteger essas áreas e deveria haver ainda, uma compensação financeira aos municípios que abrigam mananciais.

As ações e os investimentos de proteção deveriam ser organizados num "Plano de Desenvolvimento e Proteção Ambiental" - PDPA a ser elaborado para cada manancial (APRM) com a finalidade de:

- Orientar outras politicas para que elas auxiliem na proteção;

- Relacionar as ações e investimentos a serem feitos e os resultados esperados;

- $\quad$ Propor normas a serem obedecidas nas áreas de intervenção e;

- Definir programas de fiscalização, controle e educação ambiental.

Embora a Lei 9866/97 represente um avanço na proteção aos mananciais, o sistema só poderá se efetivar na medida em que forem criadas as "Leis Específicas" para cada manancial de acordo com as especificidades de cada área. De acordo com a Lei 9866, cada Lei Específica buscará identificar os seguintes tipos de Áreas de Intervenção: Restrita à Ocupação; Área de Ocupação Dirigida e Área de Recuperação Ambiental. 


\subsection{Unidades de Conservação}

"Nós não consideramos selvagens (wild) as vastas planícies abertas, os maravilhosos montes ondulados, as torrentes sinuosas. Somente para o homem branco a natureza era selvagem, e somente para nós ela era domesticada. A terra não tinha cercas e era rodeada de bênçãos do Grande Mistério." 8

De acordo com o Sistema Nacional de Unidades de Conservação (SNUC) uma unidade de conservação é definida como: “... espaço territorial e seus recursos ambientais, incluindo as águas jurisdicionais com características naturais $\mathrm{e}$ relevantes, legalmente instituído pelo Poder Público, com objetivos de conservação e limites definidos, sob regime especial de administração, ao qual se aplicam garantias adequadas de proteção".

O conceito de áreas protegidas tem evoluído de acordo com as necessidades e percepções da sociedade. O conceito de unidades de conservação surgiu com a criação do Parque Nacional de Yellowstone, em 1872, nos Estados Unidos, com o objetivo de valorizar a manutenção de grandes espaços naturais, onde o ser humano pudesse contemplar a natureza em busca de paz espiritual. No entanto, segundo Keith Thomas em seu livro "O Homem e o Mundo Natural- Mudanças de atitude em relação às plantas e aos animais (1600-1800)" 9 lançado em 1983, essas idéias já haviam surgido muito antes de 1872 , no continente europeu.

\footnotetext{
${ }^{8}$ Afirmação do chefe Standing Bear da tribo Sioux citada por Mc Luhan (1971) apud Diegues, 1996.

${ }^{9}$ Segundo Keith Thomas, na Inglaterra até o século XVII, havia um conjunto de concepções que valorizavam o mundo natural domesticado, especialmente os campos de cultivo, em detrimento ao mundo selvagem $O$ homem, a partir dessa concepção, era considerado o rei da criação e os animais, destituídos de qualquer direito e de sentidos. Esse conjunto de concepções só começou a mudar a partir do início do século XIX com o desenvolvimento da História Natural aliado as notícias que chegavam na Europa de que os povos orientais veneravam a natureza e não maltratavam os animais. Por outro lado, com o advento da revolução industrial e de seus primeiros efeitos adversos, a vida nas cidades que antes era valorizada como sinal de civilização em oposição a vida no campo, passa a ser questionada e criticada em virtude do ambiente fabril que tornava o ar irrespirável. Nesse sentido, a vida campestre passou a ser idealizada sobretudo pelas classes sociais envolvidas na produção industrial, principalmente nas cidades inglesas, havendo dessa maneira o que Thomas denomina de atitude de contemplaçào da vida selvagem, lugar de reflexão e de isolamento espiritual.
} 
A noção de "wilderness" (vida selvagem/natural) foi a concepção que influenciou a criação de parques nacionais, nos Estados Unidos da América, como áreas naturais e selvagens. Essa noção englobava grandes áreas não habitadas, especialmente aquelas decorrentes da expansão para o oeste dos Estados Unidos após o extermínio dos índios. É interessante observar que o conceito definido de áreas selvagens (unidades de conservação) referia-se a áreas que não sofrem qualquer intervenção humana, onde o homem é visitante, e não morador.

De acordo com DIEGUES (1996), nesse período já se consolidara o capitalismo americano e o processo de urbanização já estava em fase acelerada, diante do que o Estado se propunha a reservar grandes áreas naturais que ficariam à disposição das populações urbanas para fins de recreação. Nesse contexto, foram criados muitos dos parques nacionais norte-americanos, que se tornaram assim, uma importante referência ocidental e moderna para áreas protegidas.

Todavia, não era hegemônico o referencial teórico que permeava o conceito de conservação do mundo natural, no século XIX. A noção de "wilderness", que serviu de base para a criação dos parques norteamericanos foi criticada desde o seu início, especialmente pelos índios remanescentes em sua grande parte removidos de seus territórios ancestrais, na conquista para o Oeste.

No que se refere ao campo das teorias, nos Estados Unidos, no século XIX, havia duas visões de mundo natural, que tiveram grande influência no conservacionismo, dentro e fora dos Estados Unidos. De um lado, havia o preservacionismo, representado por John Muir, que apregoava a proteção da natureza contra o desenvolvimento moderno, urbano-industrial e predatório, valorizando a reverência à natureza no sentido da apreciação estética e espiritual da vida silvestre sem a presença das atividades humanas. Por outro lado, o engenheiro florestal Gifford Pinchot representava o conservacionismo que apregoava o uso racional dos recursos naturais, baseando-se em três princípios: o uso dos recursos naturais para as gerações presentes; a prevenção do desperdício; e o acesso aos recursos naturais para todos os cidadãos. O conservacionismo opunha-se à idéia de desenvolvimento ilimitado, à qualquer custo, e pode ter sido precursor do conceito de desenvolvimento sustentável (DIEGUES, 1996). 
Apesar dos conflitos entre conservacionistas e preservacionistas dos recursos naturais, a área destinada a parques nacionais e outras unidades de proteção aumentou consideravelmente, nos Estados Unidos, passando de cerca de 14 milhões de acres, em 1933 para cerca de 20 milhões, em 1946 (DIEGUES 1996).

No que se refere ao Brasil, o primeiro Parque Nacional instituído foi o de Itatiaia, no estado do Rio de Janeiro, em 1937. A criação deste parque estava atrelada às necessidades de ordem científica, que tinham como objetivo a perpetuação do aspecto primitivo da região. Ainda no final da década de 1930 foram criados os Parques Nacionais do Iguaçu e da Serra dos Órgãos (SVMA, 1998). Os parques nacionais brasileiros foram concebidos a partir da idéia da proteção aos monumentos públicos naturais ou da proteção de áreas de notável beleza. Porém, com o passar do tempo, os conceitos norteadores foram se transformando espelhando-se no que era observado em outros países, e de acordo com as classificações internacionais de áreas protegidas, abarcando desde o enfoque estético e recreativo, até o enfoque biológico, buscando a proteção da biodiversidade.

MILLER (1997) ressalta que, nos dias atuais, são três os objetivos do estabelecimento de áreas protegidas:

I. Preservar habitats naturais ou sítios culturais considerados valiosos por seu cenário, características naturais, espécies silvestres e significação religiosa ou histórica;

II. Resguardar e regular o suprimento de recursos de alto valor, tais como mananciais de água pura, plantas medicinais, peixes, madeira para usos futuro ou caça; e

III. Manter as características e a diversidade paisagística.

Em âmbito internacional, foi a União Internacional de Conservação da Natureza (UICN) que desenvolveu um sistema de classificação para as áreas protegidas, ordenando-as por seus objetivos de gestão, descritos nos diplomas legais de criação e regulamentação, e pelas práticas efetivamente aplicadas. 
No Brasil, desde as primeiras décadas do século XX, já se identificava uma preocupação em sistematizar os diferentes tipos de unidades de conservação, a despeito de muitas áreas protegidas terem sido criadas, no país, por diferentes níveis de poder (estadual e federal) e por diferentes instituições governamentais.

O primeiro esforço institucional de sistematização das áreas protegidas apareceu em 1979 com a primeira etapa do Plano de Sistema de Unidades de Conservação para o Brasil, a cargo do extinto Instituto Brasileiro de Desenvolvimento Florestal (IBDF). Porém, somente após um longo e exaustivo processo de discussão e polêmicas dentro do governo e do próprio movimento ambientalista foi que, no final de 1999, a Presidência da República sancionou o Projeto de Lei que dispõe sobre os Objetivos Nacionais de Conservação da Natureza e criou o Sistema Nacional de Unidades de Conservação (SNUC).

O SNUC tem diversos objetivos: contribuir para a manutenção da diversidade biológica e dos recursos naturais genéticos, no território nacional e nas águas jurisdicionais; proteger as espécies ameaçadas de extinção, no âmbito regional e nacional; contribuir para a preservação e a restauração da diversidade de ecossistemas naturais; promover o desenvolvimento sustentável a partir dos recursos naturais; promover a utilização dos princípios e práticas de conservação da natureza, no processo de desenvolvimento; proteger paisagens naturais e pouco alteradas de notável beleza cênica; proteger as características relevantes de natureza geológica, geomorfológica, espeleológica, arqueológica e cultural; proteger e recuperar recursos hídricos e edáficos; recuperar ou restaurar ecossistemas degradados; proporcionar meios e incentivos para atividades de pesquisa, estudos e monitoramento ambiental; valorizar econômica e socialmente a diversidade biológica; favorecer condições e promover a educação e interpretação ambiental, a recreação em contato com a natureza e o turismo ecológico; proteger os recursos naturais necessários à subsistência de populações tradicionais; respeitar e valorizar o conhecimento e a cultura de populações tradicionais promovendo-as social e economicamente. (BRASIL 1999). 
O SNUC divide as unidades de conservação em dois grandes grupos:

I. Unidades de Proteção Integral na qual é admitido, com o objetivo de preservar a natureza, apenas o uso indireto dos recursos naturais. Fazem parte desse grupo as seguintes categorias: Estação Ecológica; Reserva Biológica, Parque Nacional, Refúgio de Vida Silvestre e Monumento Natural.

II. Unidades de Conservação de Uso Sustentável, cujo objetivo é promover e assegurar o uso sustentável dos recursos naturais. É integrada pelas seguintes categorias: Área de Proteção Ambiental, Área de Relevante Interesse Ecológico; Floresta Nacional; Reserva Extrativista; Reserva de Fauna; Reserva de Desenvolvimento Sustentável; e Reserva Particular do Patrimônio Natural.

\section{5. Áreas de Proteção Ambiental e a criação da APA-Capivari-Monos}

De acordo com o Sistema Nacional de Unidades de Conservação - SNUC as Áreas de Proteção Ambiental - APAs enquadram-se no grupo das unidades de conservação de uso sustentável. São definidas como "áreas em geral extensas, com um certo grau de ocupação humana, dotada de atributos abióticos, bióticos, estéticos ou culturais especialmente importantes para a qualidade de vida e o bem estar das populações humanas, e tem como objetivos básicos proteger a diversidade biológica, disciplinar o processo de ocupação e assegurar a sustentabilidade do uso dos recursos naturais". (BRASIL, 1999)

Uma Área de Proteção Ambiental - APA é um dos tipos de Unidades de Conservação que difere das Unidades de Conservação de Proteção Integral (parques) pois, na APA, a propriedade das terras pode ser pública ou privada. A APA tem como finalidades principais:

I. Proteger a biodiversidade;

II. Proteger os recursos hídricos e os remanescentes de Mata Atlântica;

III. Promover a melhoria da qualidade de vida das populações; 
IV. Proteger o patrimônio arqueológico e natural;

V. Manter o caráter rural da região;

VI. Evitar o avanço da ocupação urbana na área protegida.

As primeiras discussões sobre a criação de uma APA na Área de Proteção aos Mananciais, na região de Parelheiros remontam à época da criação da Secretaria Municipal do Verde e do Meio Ambiente - SVMA-, do município de São Paulo, em 1993, quando técnicos ligados à área, anteriormente lotados em outras secretarias e órgãos municipais, passaram a trabalhar juntos na SVMA, buscando soluções para as questões ambientais da cidade.

Os seminários e debates ocorridos em 1995, por ocasião da elaboração da Agenda 21 Local, possibilitaram a veiculação formal da idéia da criação da APA, que foi bem recebida pela sociedade civil e pela sociedade política, localmente representada. No início de 1996, a proposta foi apresentada no CADES, tendo sido aprovada a criação de uma Comissão Especial para tratar do assunto. A Comissão estudou formas de viabilizar a idéia, reuniu dados e informações sobre a área e realizou os trabalhos de campo. Com base nesses estudos, concluiu-se que a APA era a categoria de Unidade de Conservação mais adequada para o caso. Conforme relatos da SVMA, elaborou-se então a minuta de Projeto de Lei, aprovada pelo CADES em 27 de maio de 1996.

Foi instituída, então, nova comissão especial, com o intuito de implementar a criação da APA. A nova comissão aprofundou os estudos, assessorando a Divisão Técnica de Planejamento Ambiental nos trabalhos de mapeamento e identificação da área e contribuindo para a elaboração de um relatório de caracterização socioambiental da área.

Foi contratada a consultoria do Laboratório de Geoprocessamento da Escola Politécnica da Universidade de São Paulo para executar os trabalhos de cartografia digital e realizar a análise espacial das informações e promover a capacitação da equipe técnica da Divisão de Planejamento Ambiental no uso de tecnologias de 
geoprocessamento, de forma que a equipe pudesse fazer as necessárias atualizações das informações coletadas.

Paralelamente, a minuta de Projeto de Lei aprovada pelo CADES foi encaminhada à Assessoria Técnico Legislativa do Gabinete do Prefeito - ATL que por sua vez consultou várias secretarias municipais - Secretaria das Finanças, Secretaria Municipal do Planejamento, Secretaria da Habitação e Desenvolvimento Urbano, Secretaria das Administrações Regionais e Secretaria de Serviços e Obras. Após manifestação destas, a nova comissão reestudou o projeto, que foi aprimorado, incorporando-se as contribuições das secretarias consultadas e resultando na versão final da minuta de Projeto de Lei.

A versão final da minuta foi novamente encaminhada à ATL, e finalmente encaminhada à Câmara Municipal pelo Sr. Prefeito, com o ofício ATL 145/98, em 05/06/98, resultando no Projeto de Lei 01-0412/98.

A Área de Proteção Ambiental - APA Municipal Capivari Monos foi legalmente instituida em 2001, conforme Lei 13.136/2001 da Prefeitura do Município de São Paulo, e vem se somar às leis vigentes (estaduais e federais) de proteção aos mananciais, no sentido de estabelecer regras para a racionalização da ocupação do solo e o desenvolvimento de atividades econômicas sustentáveis.

A área, hoje denominada APA Municipal Capivari-Monos, possui uma extensão territorial de $251 \mathrm{~km}^{2}$ e está inserida totalmente na área de proteção aos mananciais, abrangendo parte da bacia hidrográfica da Billings, parte da bacia de Guarapiranga, e toda a bacia hidrográfica do Rio Capivari-Monos. Esta última é uma bacia de vertente marítima, considerada reserva estratégica de água potável para a Região Metropolitana de São Paulo. Atualmente o rio Capivari contribui para o Sistema Metropolitano de Abastecimento, através da reversão de cerca de $1 \mathrm{~m}^{3} / \mathrm{s} \mathrm{de}$ suas águas para o reservatório Guarapiranga. A área abriga ainda as cabeceiras do Rio Embu-Guaçu, maior formador do reservatório Guarapiranga.

A APA Capivari-Monos comporta, aproximadamente $1 / 6$ do território do município de São Paulo, e limita-se, ao norte, pelo divisor de águas do Ribeirão Vermelho (Bacia Guarapiranga) e pelo limite da Área Natural Tombada da Cratera da Colônia (Bacia Billings); a leste, com o município de São Bernardo do Campo; a 
oeste, com os municípios de Embu-Guaçu e Juquitiba, e ao sul, com o município de Itanhaém. Fazem parte de sua área os bairros de Barragem, Cidade Nova América, Vargem Grande, Engenheiro Marsilac, Evangelista de Souza, Jardim dos Eucaliptos, Gramado, Ponte Seca, Ponte Alta e Embura do Alto. (SVMA 1998)

Desconhecida por grande parte dos habitantes da metrópole, esta região é um dos poucos locais do município onde há um predomínio de Mata Atlântica, que abriga uma diversidade ecológica bastante variada em suas espécies de fauna e flora nativas, muitas delas em extinção. A região abriga ainda uma bacia hidrográfica bastantes rica, constituída por rios importantes como o Capivari, conforme citado. Dessa forma, ao constituir-se numa importante reserva estratégica de água potável para a região para a cidade de São Paulo e para toda a região metropolitana, a APA Capivari-Monos traduz a própria viabilidade e a sustentabilidade ecológica da metrópole.

A Área de Proteção Ambiental Capivari-Monos abriga ainda três aldeias da tribo Guarani (Krucutu, Morro da Saudade e Rio Branco); uma estação de trem - a Evangelista de Souza; e também a área objeto deste estudo que é a Cratera da Colônia, tombada pelo Conselho de Defesa do Patrimônio Histórico, Arqueológico, Artístico e Turístico do Estado de São Paulo - CONDEPHAAT, em 30 de junho de 2003.

Além da vegetação nativa - Mata Atlântica em diferentes estágios sucessionais e campos naturais associados estão presentes diversos usos como: agricultura (principalmente horticultura e floricultura), reflorestamento, piscicultura, clubes e chácaras de recreio. O único núcleo urbano regular é o bairro de Engenheiro Marsilac, bastante antigo. A urbanização irregular presente nesta área não é tão significativa, se comparada ao que ocorre mais ao norte das bacias hidrográficas do Guarapiranga e Billings. Porém, nas áreas limítrofes, o vetor de expansão urbana se apresenta, claramente, na forma de loteamentos precários e invasões em acelerado processo de adensamento, exercendo uma pressão sobre os recursos hídricos, a fauna e a flora local.

Por outro lado, as alternativas sustentáveis de geração de renda, para aquelas que vivem fora das áreas urbanizadas, não parece ter sido contemplada pelas políticas públicas até hoje implementadas. Apesar da fiscalização, o desmatamento 
tem aumentado na área, conforme se verifica pelas ocorrências registradas pelo Sistema de Fiscalização Integrada SOS Mananciais. Verifica-se um grande número de desmatamentos, muitos em áreas de encosta, para dar lugar à agricultura de subsistência, com baixa rentabilidade e efeitos deletérios sobre os mananciais e sobre todo o ecossistema (SVMA 1998).

Uma vez que a taxa de aumento populacional de São Paulo tem diminuído, segundo os dados do último censo (2000), poderia se esperar que a pressão de urbanização, exercida sobre a área da APA, também diminuísse. No entanto, a taxa de crescimento nos distritos que compõem a área de proteção aos mananciais, ao contrário, tem aumentado, indicando que o adensamento da área continua a ocorrer.

Frente à magnitude dos problemas ambientais inerentes a uma metrópole das proporções de São Paulo - poluição do ar e da água, disposição inadequada de resíduos, ocupação humana em áreas de risco, poluição sonora, apenas para citar alguns - e da complexidade de seu gerenciamento, é compreensível que a zona rural, especialmente na APA- Capivari Monos, uma área tão distante do centro urbano, tenha pouco destaque nas prioridades elencadas, historicamente, pelo Poder Público. Sua proteção, no entanto, é essencial para a qualidade de vida não apenas daqueles que nela vivem, mas de todos os cidadãos e cidadãs que habitam a capital e a Região Metropolitana de São Paulo.

Nesse sentido, a criação da APA, parece representar um importante instrumento de gestão uma vez que se diferencia de outras formas de gestão, especialmente por se basear na prevenção de uma maior deterioração da área, propondo uma estratégia que procura contrapor-se ao avanço da urbanização, por meio de alternativas sustentáveis de uso das terras, que poderiam gerar renda para a população moradora mas esses aspectos representam o material para futuras investigações. 


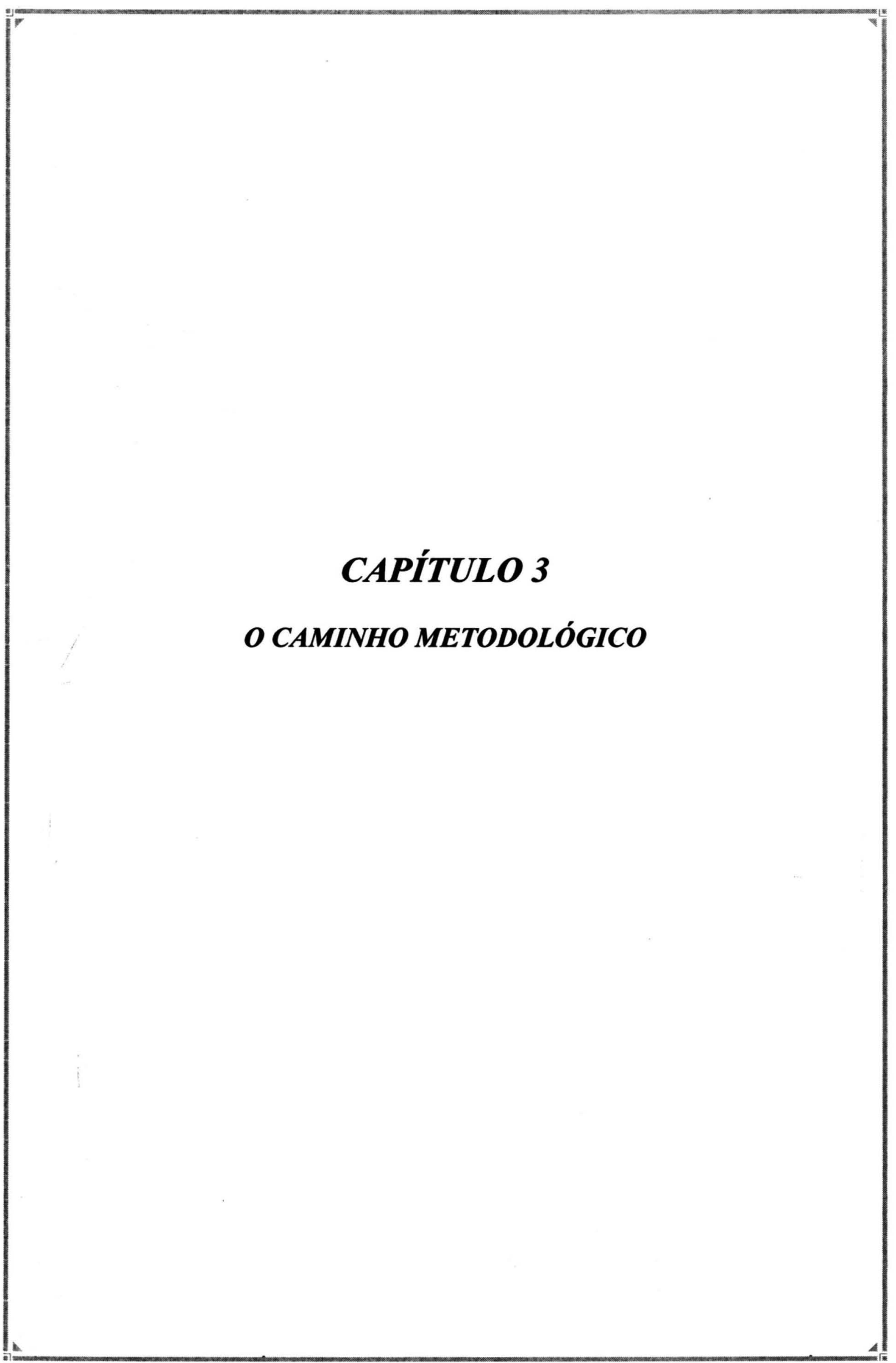




\subsection{Percorrendo o caminho da problemática socioambiental na Cratera da Colônia}

Os antecedentes desta pesquisa remontam ao ano de 1997 quando, durante a disciplina "Meio Ambiente e Saúde Pública", do curso de Mestrado em Saúde Pública na Faculdade de Saúde Pública da Universidade de São Paulo, foi apresentada, em seminário e debate entre os participantes da aula, a dissertação de Mestrado de Valério Igor P. Victorino "Os desafios sociais da questão ambiental: proteção das águas e luta por moradia na Cratera da Colônia”. O tema da dissertação era o conflito socioambiental instalado dentro de uma área de mananciais. Nesse trabalho, o autor utilizava como exemplo, o caso da ocupação urbana da Cratera da Colônia.

Na época, VICTORINO (1996) referia-se a uma população de 10.000 pessoas instalada dentro da área em situação precária no tocante às condições sanitárias. $O$ caso revelou-se bastante instigante, devido ao quadro de necessidades sociais daquela população e, principalmente, pelo descaso do poder público em relação à questão ambiental, apesar do pouco tempo decorrido após a realização da ECO-92, evento internacional durante o qual a problemática do meio ambiente nas aglomerações urbanas havia sido amplamente discutida.

No ano de 2001, a pesquisadora foi convidada por uma organização-nãogovernamental (ONG) para visitar a área da Cratera, com o objetivo de formular um curso de capacitação, durante o processo de elaboração de projetos destinados a grupos de mulheres moradoras na área.

Na visita ao local, aquela preocupação despertada em 1997 retornou com força maior. Concluído o curso de elaboração de projetos sociais, apresentava-se de forma recorrente a idéia de construir uma compreensão atualizada da problemática ambiental, que não havia sido solucionada, mas cuja evolução estava enveredando para um desdobramento ainda mais complexo.

Passados apenas cinco anos após o término da dissertação de mestrado de Victorino, o número de ocupantes da área, que antes era de 10.000 , já estava em torno de 35.000 habitantes, em uma situação bastante diferenciada em termos de construção social do espaço. 
Foi assim que a presente tese de doutoramento foi direcionada para o objetivo de compreender a problemática socioambiental na "Cratera da Colônia", a partir do ponto de vista das pessoas que vivem, em seu cotidiano, as agruras de uma área inóspita ao desenvolvimento humano, na qual, com suas próprias forças, os moradores foram erigindo as condições institucionais e coletivas para uma habitabilidade digna e construindo, paralelamente à edificação da moradia individual uma compreensão do significado de "meio ambiente", "ambiental", "ecologia", “desenvolvimento sustentável", conceitos que, entre as pessoas da comunidade do Loteamento Vargem Grande (ocupantes de grande parte da área da Cratera da Colônia) aparecem como sinônimos.

As várias formas de falar e de representar sobre a temática ambiental e os vários sentidos atribuídos à questão, assim como as várias práticas defrontadas no campo, motivaram e também contribuíram para a elaboração desta tese. Nesse sentido, buscou-se entender os argumentos que dão sustentação às representações, aos significados e aos sentidos que a questão ambiental adquire para a população da Cratera da Colônia. Cabe destacar que o ambiente é entendido, pela pesquisadora, não só nos seus aspectos naturais, mas naqueles oriundos do ambiente construído $\mathrm{e}$ nos problemas percebidos pelos moradores no seu dia-a-dia, nas responsabilidades pela situação e nas possíveis formas de solução para o caso.

\subsection{O itinerário de campo}

Tendo como premissa que os objetivos da pesquisa e a população envolvida referem-se a objetos de estudos complexos, em que a interdisciplinaridade e a transdisciplinariedade devem se constituir como uma forte presença para a construção da investigação do campo e para o desenvolvimento das diferentes etapas da pesquisa, optou-se por uma diversidade teórica e metodológica, uma vez que a complexidade do objeto demanda abordagens a partir de perspectivas diversas, com a finalidade de compreender as dimensões que formam as representações e os múltiplos sentidos atribuídos à questão ambiental, a partir das práticas sociais, dos discursos e das posições que os atores assumem no cotidiano. 
A dimensão qualitativa tem se mostrado bastante apropriada para tais casos, pois permite evidenciar os pontos de vista, as visões de mundo, o imaginário social em cujo cenário germinam as representações, as percepções, os sentidos e os significados.

Em todo o trabalho de campo houve preocupação em captar os múltiplos sentidos atribuídos ao tema investigado, a partir de conversas no cotidiano que segundo SPINK (1999), configuram-se como práticas discursivas entendidas como "as maneiras a partir das quais os vários atores produzem sentidos e se posicionam perante as situações cotidianas".

\subsection{A pesquisa exploratória}

A pesquisa exploratória foi executada entre os meses de janeiro de 2002 e junho de 2004, quando se procurou identificar os grupos organizados no bairro e as instituições sociais presentes.

As referências recebidas encontravam-se relacionadas à Associação Comunitária Habitacional do Condomínio Vargem Grande - Achave, que se constitui na principal organização comunitária existente na área.

Inicialmente estabeleceu-se uma relação de conhecimento mútuo e de confiança entre os integrantes da Associação e a pesquisadora. Na Associação, foi feito conhecimento com uma das mais importantes lideranças comunitárias da Cratera, que, mais tarde, viria a se tornar a principal interlocutora da pesquisadora na região.

Foi por meio dessa pessoa que se passou conhecer a rede de relações que se estabelecia entre os moradores da Cratera, as instituições ali presentes e aquelas estabelecidas com instituições externas à Cratera. $\mathrm{O}$ caminho percorrido foi inspirado no conceito de rede, que segundo SCHERER-WARREN (1999), é utilizado cientificamente, tanto para denominar-se um conceito teórico, como também uma estratégia metodológica.

Considera-se que a temática ambiental se constitui num campo altamente complexo, o que requer uma conceituação bastante clara que permita nortear a 
exploração do campo. Representações, percepções, sentidos e significados e conceitos, como por exemplo, o conceito de ambiente, não existem no vazio, mas há uma matriz de instituições, conhecimentos, profissionais, leis, objetos específicos, locais, pessoas e outros, que servem de sustento a esse conceito ou a essa idéia. Nesse sentido, a pergunta norteadora para se entender essa matriz é: de que forma os conceitos de ambiente "ecologia", "desenvolvimento sustentável" foram sendo absorvidos, decodificados e reconstruídos pelos atores da Cratera?

\subsection{Observação etnográfica e registro fotográfico}

A primeira etapa da pesquisa consistiu na observação das variáveis de campo, a partir de contribuições da antropologia. Entende-se como contribuição etnográfica o uso da chamada "observação participante", desenvolvida pela antropologia clássica, mais precisamente por MALINOWSKI (1975) e por RADCLIFFEBROWN (1975), entre outros.

Esta fase da pesquisa ocorre quando o pesquisador entra no espaço do campo, realizando a observação e o registro de fatos e situações, isto é, das "evidências", detectando fontes de dados que possam contemplar atores e atrizes sociais, considerando suas vozes e o contexto em que estão inseridos. Esta fase constituiu-se na fundamentação para o segundo momento da pesquisa em que serão realizadas as etapas subseqüentes da investigação, no caso, as entrevistas e os grupos focais. As observações captadas no campo foram registradas em forma de "diário de campo" e também por meio de registro fotográfico.

O trabalho etnográfico e os registros fotográficos tiveram início com um reconhecimento, por meio de observação em caminhada a pé, por toda a Cratera, a fim de buscar aqueles elementos reconhecidamente significativos da história daquele "pedaço" de São Paulo. Houve ainda, participação da pesquisadora em atividades de educação ambiental implementadas pela ACHAVE, e participação nas festas populares do lugar.

De posse das inúmeras fotografias feitas na Cratera, o trabalho seguinte foi escolher as imagens que melhor representariam os cenários que identificassem a 
problemática ambiental ali instalada. Foram agregadas ao registro fotográfico outras imagens que faziam parte do acervo da Associação, além de fotografias do acervo pessoal de nossos interlocutores e interlocutoras, identificados na localidade no decorrer do estudo fotográfico.

De acordo com Kuhnen (2002), a organização do material fotográfico traz, inerentes, as representações de quem as elabora: olhar simplesmente, e olhar por meio de uma lente, implicam posições diferentes do pesquisador. Nesse sentido, o material fotográfico buscava trazer à tona as representações dos sujeitos, porém estas foram explicitadas a partir das representações sobre a temática ambiental desta pesquisadora.

As fotos foram organizadas em dez grupos, cada um composto de quatro fotografias. Essa seleção pretendia colocar o entrevistado ou entrevistada frente a algumas imagens que continham alguma similaridade, e que lhe sugerissem alguma coisa a dizer (KUHNEN 2002).

Cabe destacar que, embora o uso de imagens em pesquisas sociais ainda se trata de um território pouco consolidado, tal método tem se revelado como um desencadeador para evocar memórias de pessoas que uma entrevista dificilmente conseguiria. Mais do que memórias ativas e presentes, as imagens têm um importante papel no acesso de memórias passadas (LOIZOS 2002).

No Brasil, pesquisadores como Mary Jane Spink do Núcleo de Pesquisa sobre Práticas Discursivas e Produção de Sentido, têm buscado trabalhar a interface entre os aspectos discursivos e a rede de materialidades em que as imagens estão inseridas. Segundo essa autora, esta perspectiva tem o sentido de questionar a postura representacionista no estudo das imagens, e busca entendê-la como prática discursiva instituidora de fatos e modos de subjetivação; dessa maneira, as imagens assim consideradas passam a concentrar grande poder na produção de sentidos. Essa abordagem tem se constituído em um movimento recente (SPINK 2003).

Dessa forma, o estatuto da imagem usada neste trabalho não se refere apenas a ilustrações da problemática socioambiental estabelecida na Cratera da Colônia, mas são imagens que contam uma história, isto é, passam de um patamar meramente 
ilustrativo de acontecimentos descritos em palavras, para uma linguagem viva plena de movimentos e reações dos indivíduos.

\subsection{Entrevistas}

Nesta etapa procurou-se investigar as diversas representações, sentidos e significados, por meio de uma série de entrevistas abertas, em profundidade com informantes qualificados e representativos dos grupos, com o objetivo de traçar o desenvolvimento, a configuração e a composição destes campos de forças que abarcam a questão a pesquisar.

Para estabelecer o que as pessoas que participaram desta pesquisa definiram como questão socioambiental, as entrevistas foram sempre iniciadas com uma breve introdução, por meio da qual se tentava esclarecer o foco da pesquisa, podendo variar segundo o local da entrevista, a pessoa entrevistada e a sensibilidade da pesquisadora para introduzir o tema no momento mais oportuno. Tais cuidados foram adotados porque, na Cratera, o tema ambiental tende a despertar desconfianças e atitudes defensivas também observadas no estudo realizado por GARCIA, em 2004.

Esse fato foi um elemento importante e sempre esteve presente em cada um dos encontros mantidos com os interlocutores. Foi necessário lançar mão de vários recursos argumentativos, para contornar possíveis resistências ou mal entendidos, que pudessem dificultar as conversas, buscando sempre a construção de um ambiente de descontração e respeito mútuo, frente a posições por vezes conflituosas e abertamente críticas. As entrevistas foram realizadas seguindo a lógica do diálogo, ajustando as formas de abordagem de modo a encontrar a melhor maneira para discutir um tema, com vistas a oferecer uma abertura maior ao assunto em pauta (REY 2002; GARCIA 2004).

Os espaços criados pelas entrevistas individuais e coletivas são momentos privilegiados na atribuição de sentido e significação ao processo de coleta de dados, tanto para o pesquisador como para os sujeitos da pesquisa, assim como na contextualização das informações recolhidas. A entrevista, entendida como um espaço de comunicação dialógica, permite tanto a obtenção de informações denominadas mais objetivas, como outras de caráter mais subjetivo, referentes às 
atitudes, opiniões, sentimentos e valores dos sujeitos entrevistados. Como na presente pesquisa havia a intenção de obter informações de caráter biográfico, referentes às histórias de vida dos entrevistados e entrevistadas, foi de fundamental importância a constituição de espaços e tempos muito bem cuidados e alicerçados em diálogos face-a-face.

REY (2002), em sua argumentação acerca do lugar da comunicação na pesquisa qualitativa, enfatiza algumas premissas a serem observadas na interação entre o pesquisador $\mathrm{e}$ os sujeitos entrevistados. São elas: a) a presença do pesquisador representa um elemento no sentido que influencia, de forma marcante o envolvimento do entrevistado; b) os entrevistados não respondem linearmente às perguntas de natureza aberta que lhes são feitas, e sim constroem argumentos na interação com o pesquisador e manifestam, em suas respostas, contradições estimuladas pelo próprio exercício da comunicação; c) uma pergunta aberta não encerra seu potencial nas categorias estabelecidas, a priori, e mesmo no momento único em que ela ocorre, mas costuma desdobrar-se e manter-se latente em outros espaços e momentos vividos pelos entrevistados; e d) todo contato entre o pesquisador e o entrevistado ou a entrevistada já é, por si só, uma intervenção.

Utilizou-se a palavra 'panorama' para se referir à diversidade de discursos e vozes das várias instituições, pessoas e grupos envolvidos na questão ambiental. Foram inseridos como parte integrante da construção da problemática socioambiental, na Cratera da Colônia, os discursos dos ambientalistas, dos médicos e de técnicos da Prefeitura Municipal de São Paulo, como interlocutores-chave.

Cada entrevista foi transcrita na integra e, a partir desses relatos, buscou-se identificar temas presentes nos eixos temáticos definidos para orientar as entrevistas: de que forma aconteceu o processo de ocupação da Cratera; de que modo aconteceu a aproximação com a questão ambiental; quais os problemas ambientais mais relevantes para a população; quais as possiveis formas de enfrentamento da questão; e outros aspectos.

Inicialmente foi elaborado um roteiro prévio, contendo apenas uma primeira divisão entre as questões por temas. Essa categorização preliminar por temas tinha como objetivo organizar as informações que emergiram no campo. 
No momento das entrevistas eram apresentados, aos entrevistados, os painéis fotográficos, para que as pessoas discorressem sobre os temas propostos. Essa metodologia tinha por objetivo trazer à tona determinadas representações.

Para a elaboração da análise temática (BARDIN 1995), a consulta do material coletado teve início com a transcrição das fitas e com a leitura atenta de cada um dos depoimentos, extraindo-se deles as questões e problemas referidos pelos informantes.

\subsection{Grupos focais}

Foram realizados dois grupos focais com grupos de moradoras, com o objetivo de discutir e debater questões relacionadas à questão socioambiental em sua localidade. Partindo-se do pressuposto que percepções, atitudes, opiniões e representações são socialmente construídas, a utilização de sessões grupais como técnica de pesquisa é recomendada por diversos pesquisadores sociais; devido à possibilidade de pensar coletivamente uma temática que faz parte da vida das pessoas, os comentários de umas facilitam o emergir das opiniões e, representações de outras.

Outro ponto positivo a ser destacado sobre a pertinência do uso de grupos focais em pesquisas é que as histórias e as posturas dos interlocutores fluem de maneira muita mais espontânea e diversificada nos grupos, do que em entrevistas, pois pode-se perceber, nas situações de grupo, uma interrelação dialógica muito mais rica, em que as diversas vozes entram em negociação de versões e de posicionamentos.

\subsection{Pesquisa documental}

Foram estudados os múltiplos sentidos atribuídos à problemática socioambiental, a partir das práticas sociais e dos discursos e posições que estas assumem no cotidiano, assim como a partir dos diversos documentos impressos, fotografados e filmados disponiveis a respeito da temática. 
Esta etapa se constituiu no levantamento do material documental de domínio público disponível, sejam eles relatórios de pesquisa, material de divulgação, material de planejamento de atividades, material didático, folder, entre outros. (SPINK P 1999).

De acordo com LÜDKE \& ANDRE (1986) o uso da análise documental é indicada quando se pretende ratificar e validar informações obtidas por outras técnicas de coletas de dados e informações.

\subsection{Análise dos dados: análise de conteúdos das falas, dos materiais e triangulação}

O material documental advindo do universo representacional da população investigada, boletins, jornais, e outros, assim como as entrevistas efetuadas, foram analisadas com base nas técnicas de análise de conteúdo temática (BARDIN 1980).

As entrevistas foram analisadas a partir das formas como os participantes expressaram seus entendimentos, posturas afetivas e experiências sobre os temas em pauta, focalizando o uso de repertórios sobre a questão ambiental e as resignificações desses repertórios no contexto de suas experiências no local.

No processo de argumentação, participantes e pesquisadora lançam mão de determinados repertórios e discursos disponíveis, estruturando a escolha de frases, conceitos e figuras discursivas. Desse modo, ao relatar suas experiências buscando dar sentido à questão socioambiental, as pessoas da Cratera fizeram uso de repertórios compartilhados, quer fossem convergentes ou não, que circulam no lugar. Da mesma forma, a pesquisadora entra no jogo de posicionamento, trazendo sentidos confluentes ou contrapostos que se incorporam nessa construção (GARCIA 2004).

O objetivo dessa análise foi oferecer uma visão ampla sobre a forma como os diversos interlocutores, nesta pesquisa, definem a questão ambiental na Cratera, principalmente no que se refere aos seus desdobramentos mais específicos.

Outra técnica utilizada na análise dos dados foi a triangulação. O processo de análise por meio da triangulação de dados foi introduzido na década de 1970 por DENZIN e aprofundada por PATTON (1987). Inicialmente, o desenho do procedimento metodológico da triangulação procurava estabelecer bases para uma 
validação dos dados no sentido clássico do termo, isto é, como busca da essência do fenômeno na relação entre o real e a teorização sobre o real. Porém, com o passar dos anos, a triangulação começou a perder essa conotação de estratégia de validação, emergindo como alternativa à validação, ou seja, emergindo como aprofundamento da análise e não como caminho para chegar à verdade objetiva (SPINK 1993).

De acordo com PATTON (1987) a triangulação é considerada fundamental para verificar a propriedade das interpretações apoiadas em dados qualitativos, e permite observar a realidade a partir de diferentes ângulos o que possibilita uma discussão interativa dos dados. Utilizando-se de multimeios a "triangulação múltipla”, ou seja, o cruzamento por meio das especificidades teóricas e das fontes e, por último, o cruzamento de técnicas metodológicas (observação, entrevistas, dados quantitativos) constitui-se também num caminho que permite a superação dos vieses associados a metodologias especificas, visando a uma compreensão em profundidade e a uma maior segurança na análise interpretativa.

A proposta da "triangulação" é desenvolver uma análise das relações do contexto, em conjugação com as falas e com as ações. As investigações com essas especificidades caracterizam, atualmente, as pesquisas na área de ciências humanas e sociais, inclusive aquelas aplicadas à área da saúde. 


\section{CAPÍTULO 4}

\section{O LUGAR DA PESQUISA}
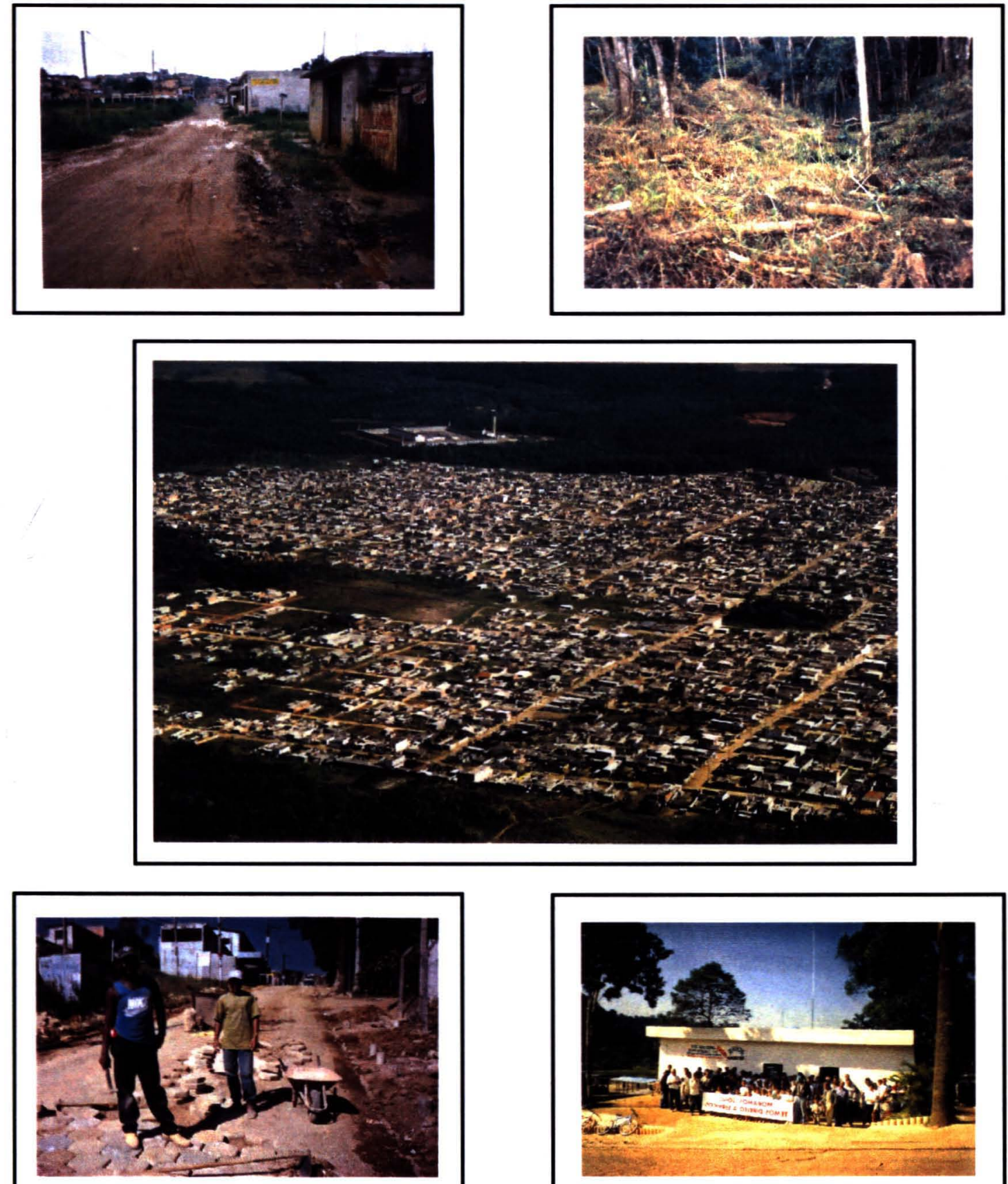
"Essa Colónia Paulista

É um lugar interessante

E eu vou contar agora

Um caso tão fascinante

Que o amigo vai ficar Querendo ver num instante" 10

Buscou-se trazer para esta tese uma reflexão que permitisse discutir as questões teóricas e contextuais mais amplas, associadas às transformações socioambientais pelas quais vem passando a área conhecida como "Cratera da Colônia" e com o objetivo de delinear de que modo essas questões se manifestam, no contexto específico do cotidiano dos atores envolvidos em torno do debate ambiental.

\section{1. “Cratera da Colônia": exemplo concreto de transformações socioambientais}

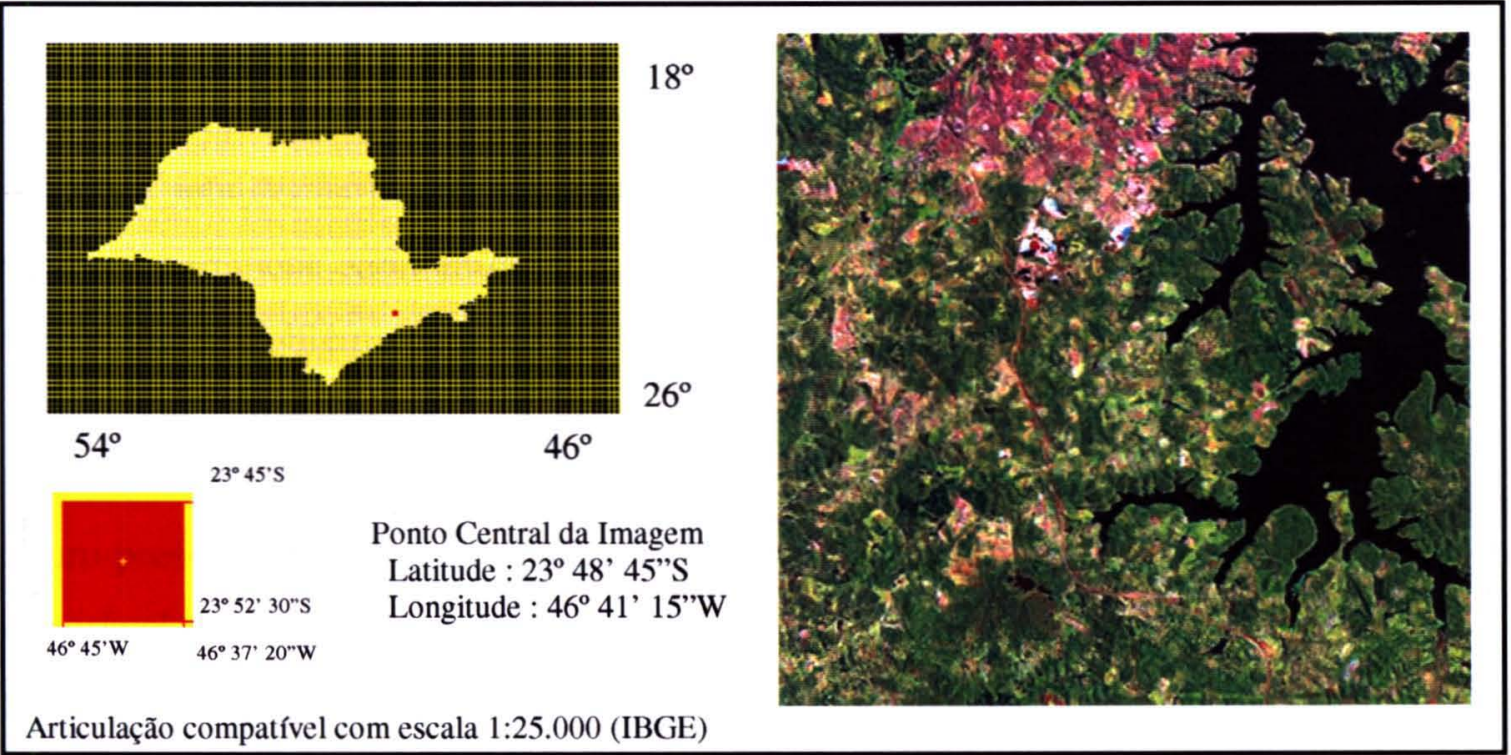

Figura 1 - Estrutura Circular da Cratera da Colônia. Imagem obtida através do Satélite Landsat.

Fonte: EMBRAPA. Disponível em <URL: http://www.cdbrasil.cnpm.embrapa.br/sp/htm0/sp46 58.htm> [2004 Nov 01].

A Cratera da Colônia, ou Astroblema, como é chamada essa estrutura de impacto provocada, provavelmente, por quedas de astros celestes, localiza-se no Distrito de Parelheiros, na Região Metropolitana de São Paulo. Situa-se a 35 km ao sul da Praça da Sé, em área onde se encontram as bacias que dão origem aos reservatórios de Guarapiranga e Billings.

\footnotetext{
${ }^{10}$ Valdeck de Garanhuns: o cordel encontra-se em versão integral no início deste trabalho.
} 
Cabe destacar que essa estrutura geológica encontra-se inserida, em sua totalidade, na Área de Proteção Ambiental - APA Capivari-Monos caracterizada como uma das principais unidades de conservação da Região Metropolitana de São Paulo.

Segundo RICCOMINI (1992), os primeiros estudos sobre o local, elaborados no início da década de 1960, evidenciavam que essa estrutura geológica vinha sendo considerada como testemunho do impacto de um corpo celeste (meteorito ou cometa), o que permitiu caracterizá-la como um Astroblema".

Em seus estudos, GRIEVE \& ROBERTSON (1979), enfatizam que cerca de 160 estruturas dessa natureza são conhecidas no planeta Terra, muitas ainda não investigadas. A maioria dessas crateras pode ser encontrada no hemisfério norte, em situações climáticas temperadas a frias.

Os astroblemas, enquanto campo de investigações científicas, não só se apresentam como um dos recentes paradigmas para explicar a evolução do planeta Terra com relação às mudanças geológicas e geoclimáticas, mas também possuem grande importância econômica como áreas potencialmente ricas em depósitos de minérios. O Astroblema de Vredefort (300 km; 2 bilhões de anos), na África do Sul, é considerado uma das maiores e mais antigas estruturas de impacto conhecidas na Terra. Este formou um domo e a bacia de Witwatersrand, fonte de $50 \%$ das jazidas de ouro presentes no planeta. A estrutura de Sudbury (250 km; 1,85 bilhões de anos) comparável ao anterior em tamanho e idade, é a maior fonte de níquel do mundo. (HACHIRO 2004).

O astroblema mais famoso do mundo é o de Chicxulub, na Península de Yucutan (Golfo do México), encontrado durante atividades de prospecção de petróleo . Este astroblema vem sendo intensamente pesquisado pois há fortes indícios de que esta estrutura de impacto, causado pela queda de um asteróide, teria provocado a extinção dos dinossauros que habitavam o planeta, há 65 milhões de

\footnotetext{
"Astroblema é o nome atribuido, pelos cientistas, às crateras antigas e já parcialmente desgastadas pela erosão, produzidas pelo impacto de corpos celestes de grande dimensão (asteróide ou cometa). O termo é originado do latim, significando uma cicatriz (blema), causada pelo impacto de um corpo celeste (astro) ( CRÓSTA 2003).
} 
anos. Por meio de imagens geofísicas (Figuras 2 a 5), vê-se uma cratera de 200 km de diâmetro, submersa, resultado do impacto de um asteróide com $20 \mathrm{~km}$ de diâmetro e, segundo os cientistas, capaz de extinguir muitas formas de vidas da época (CRÓSTA 2003; HACHIRO 2004).

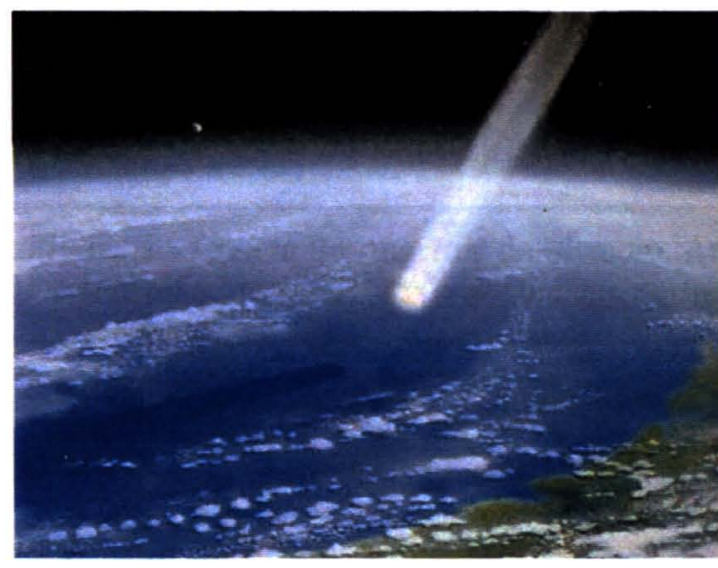

Figura 2 - Trajetória do corpo celeste(a)

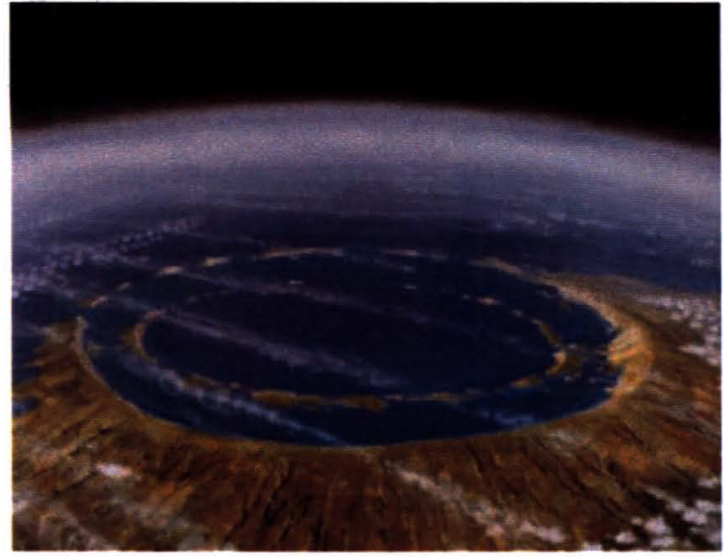

Figura 4-O local do impacto, mil anos depois (c)

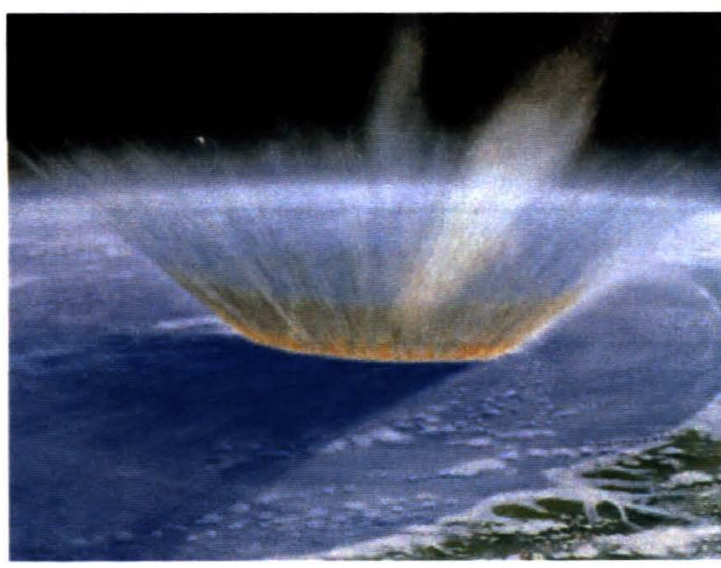

Figura 3 - Momento do impacto (b)

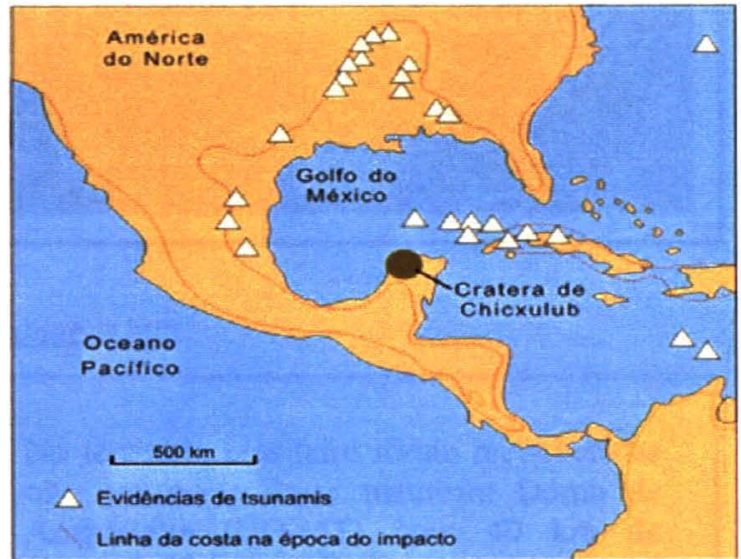

Figura 5 - Localização atual da suposta cratera em Chicxulub, México (d)

Fonte: (a - c) William K. Hartmann (d) A. R. Hildebrand \& W. V. Boynton, 1991. Adaptado de: Hachiro J. Crateras por impacto de corpos extraterrestres - Astroblemas. Geociências. Disponível em <URL: http://www.igc.usp.br/geologia/astroblema.php> [2004 Nov 01]. 


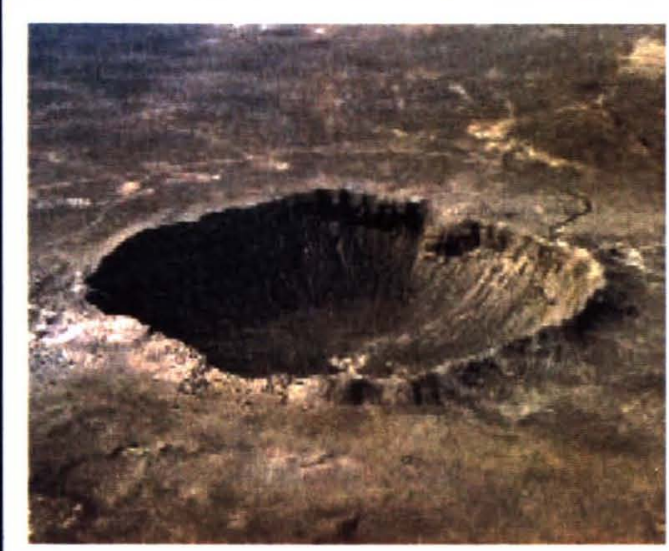

A mais recente e a mais preservada destas depressões, detectada pelos cientistas, é a Cratera do Meteoro, Arizona, nos Estados Unidos, aberta por um meteoro há somente 55 mil anos. Apesar de sua dimensão pequena com $1 \mathrm{~km}$ de diâmetro, ela se encontra pouco afetada pela erosão por estar em área desértica, servindo de modelo para o estudo de outros astroblemas no planeta.

Figura 6 - Cratera Barringer ou do Meteoro, Arizona (EUA).

Disponível em: <URL: http/www.unicamp.br/unicamp hoje>

A cidade que se vê ao lado é Nordlingen e localiza-se na Alemanha. A cidade está situada numa cratera chamada Ries e tem cerca de $25 \mathrm{~km}$ de diâmetro. Estudos comprovaram a sua origem como sendo formada pelo impacto de um meteorito há cerca de quinze milhões de anos atrás. A cidade de Nordlingen, atualmente, se transformou num importante centro turístico e sedia o Museu da Cratera de Ries, que possui dentre várias evidências geológicas do lugar, pedaços de rochas lunares colhidas pela Missão Apolo 16.

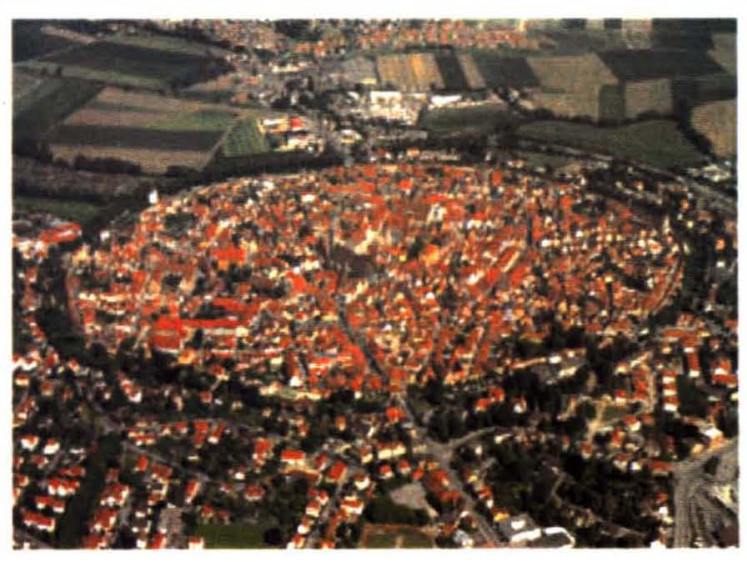

Figura 7 - Cratera de Ries, Nordlingen (Alemanha)

Disponível em: http://www.graziella.de/port/estrada/nordlingen.htm

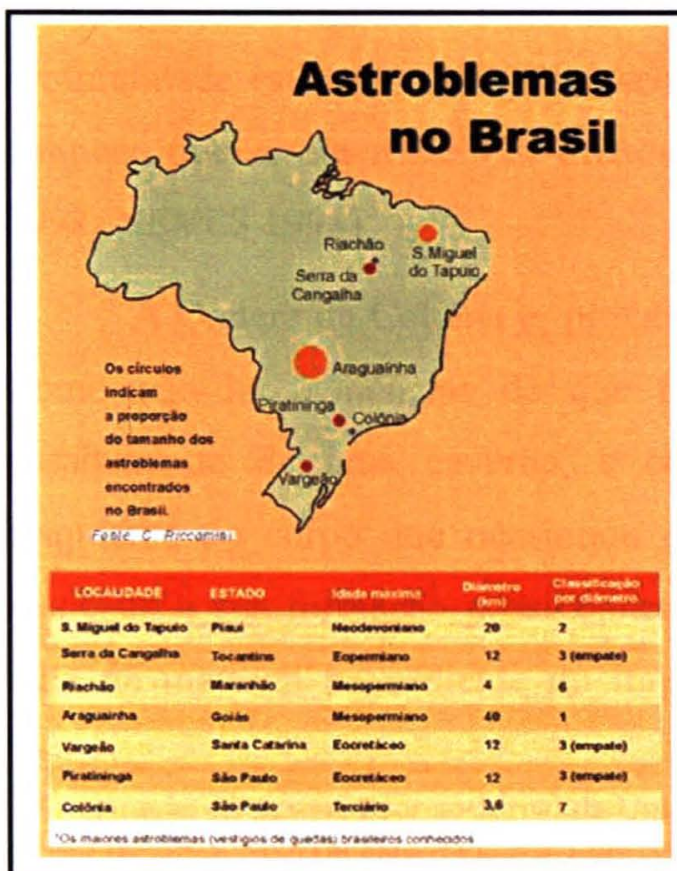

No território brasileiro foram reconhecidas oito estruturas dessa natureza: Domo de Araguainha (GO-MT) com $40 \mathrm{~km}$ de diâmetro; Serra da Cangalha (TO) com 12 km; São Miguel de Tapuio (PI) com 20 km; Vargeão (SC) com 12km; Riachão (MA) com 4,5 km; Colônia (SP) com 3,5 km. de diâmetro, Cerro Jarau (RS) e Piratininga (SP) com $12 \mathrm{~km}$. O número real tende a ser maior, no Brasil, pois ainda não foi feita nenhuma busca mais sistemática. Muitas podem estar escondidas pela densa floresta amazônica, prevê o geólogo CRÓSTA, que acredita que as últimas ferramentas de sensoriamento remoto, como as imagens topográficas geradas recentemente pela NASA por meio de radar interferométrico, vão facilitar a identificação de novas estruturas dessa natureza. (CRÓSTA 2003).

Figura 8 - Astroblema no Brasil. Fonte da Figura: C Riccomini.

Disponível em: <URL: http/www.unicamp.br/unicamp hoje> [2004 Nov 01]. 
Álvaro Crósta, pesquisador do Instituto de Geologia da UNICAMP Universidade Estadual de Campinas, que vem se dedicando ao estudo do Astroblema de Araguainha, no estado do Mato Grosso, chama a atenção para o fato da importância dos estudos, em detalhes, de todas as crateras brasileiras, como forma de contribuir para o conhecimento da evolução do planeta destacando que ainda não há investigações mais detalhadas sobre a Cratera da Colônia, na região de Parelheiros.

“O trem para Santos, antes de descer a Serra do Mar, contornava a depressão antes de seguir viagem. Como a Cratera se formou numa área em franco processo de erosão, com o tempo virou um lago, acumulando sedimentos no fundo. Precisariamos de perfurações com mais de 300 metros para chegar às rochas deformadas e determinar com precisão a sua origem" lamenta o geólogo Alvaro Crosta. ${ }^{12}$

A descoberta da existência da Cratera da Colônia, ocorrida em 1961, foi acidental e verificou-se a partir de fotos aéreas. Desde 1987, pesquisadores do Instituto de Astronomia, Geofísica e Ciências Atmosféricas da Universidade de São Paulo, vêm desenvolvendo estudos na área.

De acordo com fotografias aéreas e imagens de satélite, a Cratera da Colônia apresenta forma circular bem definida, com 3.640 metros de diâmetro e uma profundidade estimada de $900 \mathrm{~m}$, sendo circundada por um anel externo de relevo colinoso que se eleva até 125 metros da planície central pantanosa. (RICCOMINI 1992; NEVES 1998).

A Cratera da Colônia é, provavelmente, a única perto de uma grande cidade. Como não há evidências de que tenha sido formada por um vulcão ou por desabamento de uma caverna, e como também ainda não foram encontrados resquícios do corpo que ocasionou o imenso buraco, por exclusão, os cientistas associam a sua formação possivelmente à queda de um astro celeste. Por causa da falta de material proveniente do impacto, é dificil precisar o tempo em que ele

\footnotetext{
${ }^{12}$ Declaraçào do pesquisador ao Jornal da Unicamp. Universidade Estadual de Campinas, 18 a 24 de agosto de 2003. Matéria elaborada por Luiz Sugimoto.
} 
ocorreu, embora o grau de preservação indique algo em torno de 36 milhões de anos atrás.

Em recente estudo pelo método sísmico, NEVES (1998) conclui a sua pesquisa apresentando evidências sísmicas que reforçam a hipótese de impacto, como origem da estrutura circular da Colônia. Contudo, na opinião deste pesquisador a confirmação definitiva de uma origem por impacto meteorítico terá que ser baseada em evidências geológicas.

Devido à importância científica, paisagística e ambiental, a área foi recentemente incorporada ao Patrimônio Histórico da Cidade de São Paulo. De acordo com RICCOMINI (1992), a Cratera da Colônia guarda, no seu interior, um pacote sedimentar de aproximadamente $440 \mathrm{~m}$ de espessura, que deve conter o registro paleoclimático de toda a região que engloba a cidade de São Paulo. Segundo esse mesmo autor, os estudos paleoclimáticos extrapolam o interesse regional, à medida que permitem a reconstrução das condições ambientais do passado geológico recente, se forem relacionadas com as mudanças climáticas do planeta.

\subsection{Caracterização socioambiental}

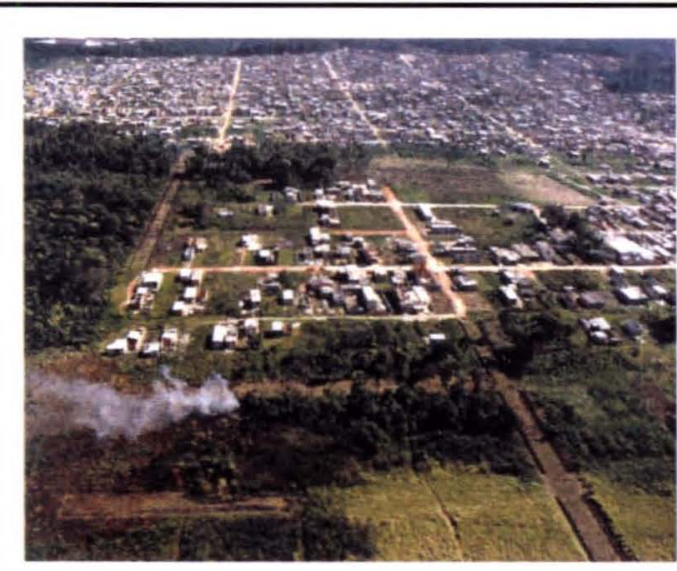

Figura 9 - Vista aérea do Condomínio Habit. Vargem Grande. Foto cedida por: ACHAVE

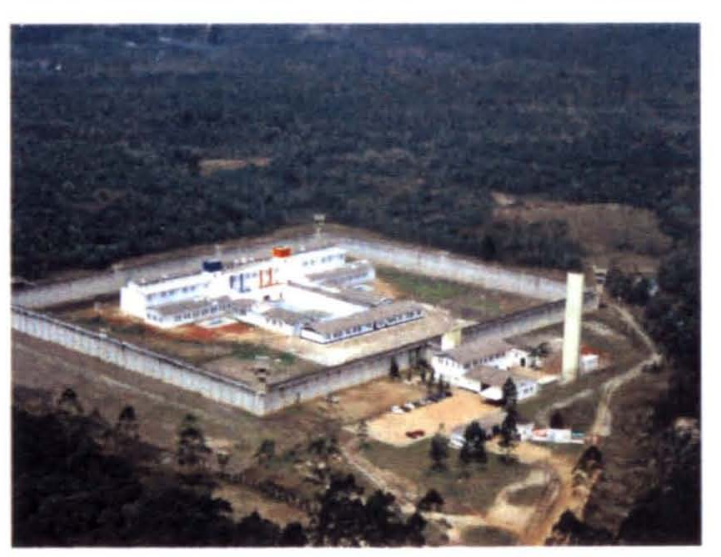

Figura 10 - Vista aérea do Presídio Estadual de Parelheiros. Foto cedida por: ACHAVE

O Condomínio Habitacional Vargem Grande é um loteamento clandestino, classificado como loteamento denso, que vem ocupando parte da área compreendida 
pela Cratera da Colônia desde o final da década de 1980. Além do Condomínio Vargem Grande, a Cratera da Colônia também sedia as instalações do Presídio Estadual de Parelheiros, construído no fim da década de 1980 pelo governo estadual. Cabe ressaltar a incoerência e a ilegalidade do próprio poder público, ao construir um presídio em área não permitida, considerando os aspectos de proteção ambiental a serem observados, conforme o disposto na Legislação Estadual de Proteção aos Mananciais e no Zoneamento Municipal da época.

Ocupam ainda parte da Cratera da Colônia aproximadamente 5.000 habitantes da Comunidade Nova América, que habitam a área há cerca de 30 anos, conforme relatos de um líder comunitário.

O processo de ocupação da Cratera da Colônia é resultado de um movimento popular denominado UNIFAG - União das Favelas da Micro Região do Grajaú. Não se trata de uma invasão, mas de um loteamento organizado, em que a UNIFAG formou uma cooperativa e adquiriu, no ano de 1988, uma gleba com cerca de 300 hectares de mata (VICTORINO 1996).

Sem a aprovação legal junto aos órgãos competentes, a entidade promoveu o parcelamento da gleba em lotes de $250 \mathrm{~m}^{2}$. Cabe lembrar que o mínimo permitido pela Legislação Estadual de Proteção aos Mananciais é de $500 \mathrm{~m}^{2}$, desde que preservadas as áreas de primeira categoria (parte da gleba era ocupada por matas e por planície aluvial). De acordo com BELLENZANI (2000), devido às restrições legais impostas às condições do sítio, o loteamento dificilmente seria aprovado. Segundo essa autora, a ocupação da Cratera não foi gradual, mas abrupta e premeditada. O processo de desmatamento, parcelamento e ocupação do solo ocorreu de forma muito rápida.

O Condomínio Vargem Grande ocupa mais da metade da gleba, com 5.413 lotes demarcados. O arruamento é retilíneo e uniforme, e foi construído pelos próprios cooperados, em desrespeito ao padrão de drenagem local, avançando sobre a planície aluvial da Cratera da Colônia, o que produziu uma ocupação comprovadamente inadequada sob o ponto de vista da legislação sanitária e ambiental. Naquele sítio, o nivel do aqüífero é muito superficial, e em muitos pontos aflorante, o que torna inviável a instalação de fossas sépticas, pois propicia a 
contaminação do lençol freático. Como não há sistema de esgotamento sanitário, a maior parte das residências possui fossas negras, e outras residências lançam seus dejetos diretamente nos córregos e valas presentes na área. Num rápido percurso pelo local pode-se visualizar o lançamento de esgotos provenientes das moradias, escoando pelas ruas a céu aberto.

Apesar de grande parte da população possuir rede de abastecimento de água, um percentual elevado de famílias utiliza-se de água provenientes de poços freáticos, como demonstrado pela Figura 11.

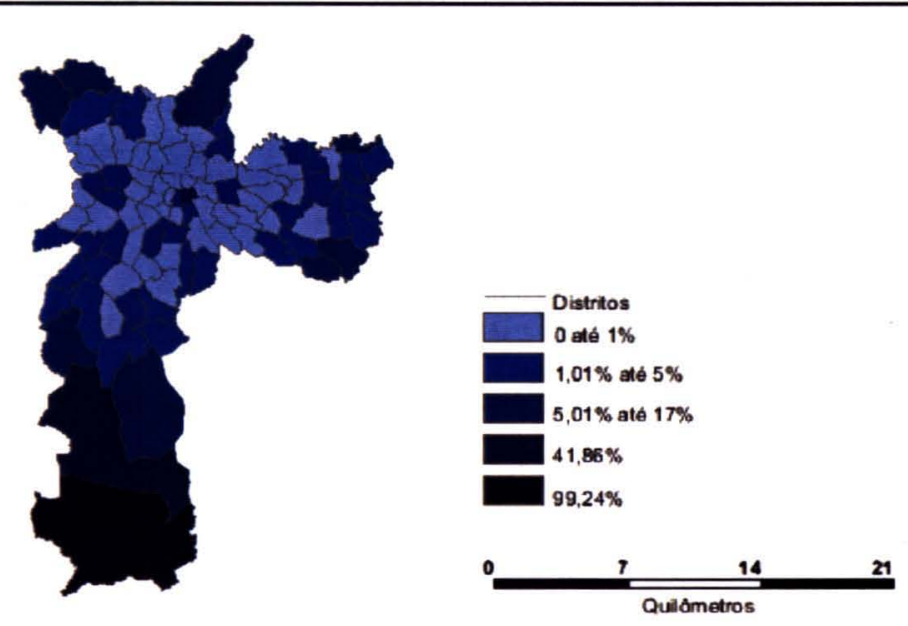

Figura 11 - Proporção de domicílios particulares permanentes, com forma de abastecimento de água não recomendáveis sanitariamente, segundo distritos do Município de São Paulo, 2000. Fonte: Fundação SEADE. Disponível em http://www.seade.gov.br/produtos/msp/sne/sne1_m001.pdf

Conforme depoimento de uma médica do PSF local, a falta de saneamento básico contribui, sobremaneira, para a elevação da incidência de doenças por veiculação hídrica na região pois, muitos desses poços encontram-se contaminados pelos esgotos e dejetos lançados diretamente no solo e nas valas. 


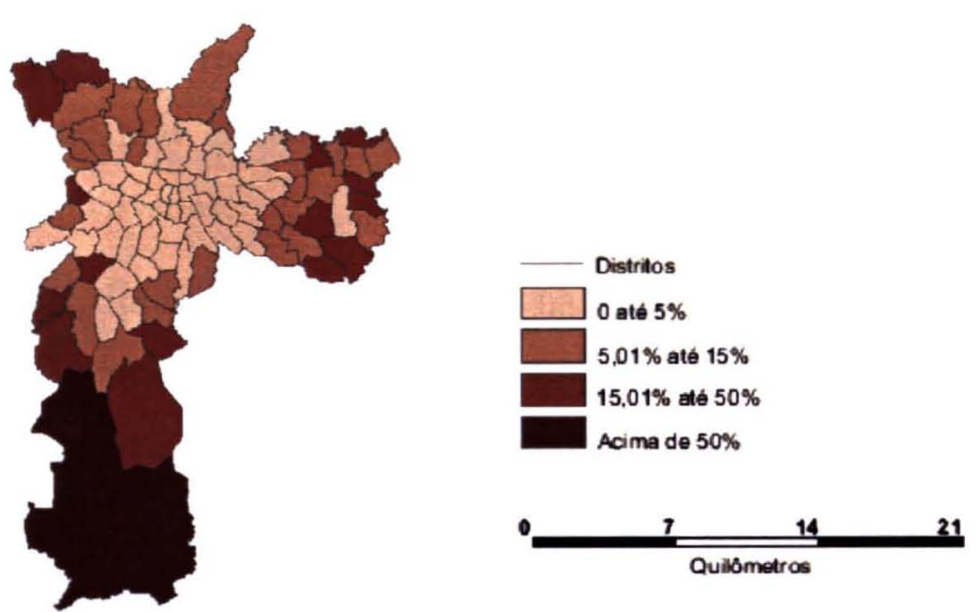

Figura 12 - Proporção de domicílios particulares permanentes, com forma de esgotos sanitários nocivas, segundo distritos do Município de São Paulo, SP,2000. Fonte: Fundação SEADE. Disponível em http://www.seade.gov.br/produtos/msp/sne/sne2_m001.pdf

O acúmulo de lixo nas ruas também é um dos graves problemas ambientais da Cratera da Colônia. Apenas nas ruas centrais da Cratera há acesso para os caminhões coletores de lixo; nas áreas mais periféricas da Cratera as famílias despejam o lixo a céu aberto, o que se converte em graves problemas de poluição ambiental, com efeitos danosos à saúde da população. Tais problemas são agravados na época das chuvas, pois muitas residências localizam-se em áreas periféricas da Cratera, onde o terreno encontra-se em área de várzea e a proximidade com o Ribeirão Vermelho é bem pequena, o que contribui para que muitas casas sejam atingidas pelas águas do rio.

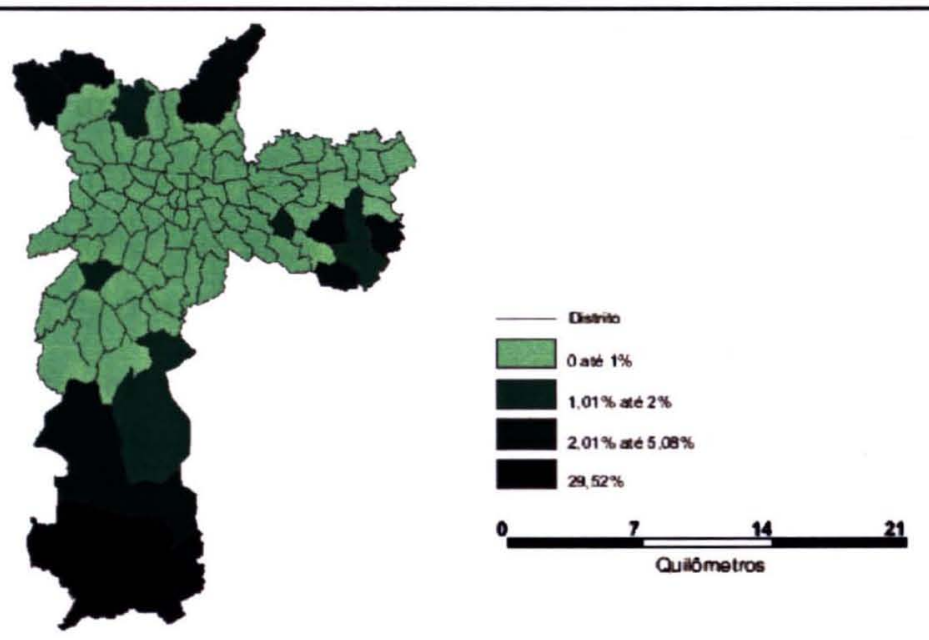

Figura 13 - Proporção de domicílios particulares permanentes, com forma de destinação do lixo nocivas, segundo distritos do Município de São Paulo, SP, 2000. Fonte: Fundação SEADE. Disponível em http://www.seade.gov.br/produtos/msp/sne/sne3_m001.pdf 
Quanto à iluminação pública, existe somente nas ruas mais centrais, motivo de muitas reclamações por parte dos moradores. A falta de iluminação nas ruas mais periféricas contribui para o aumento da violência na área, conforme relatam os entrevistados e as entrevistadas.

No tocante aos tipos de solos presentes na Cratera, grande parte destes são caracterizados como campos de várzea: apresentam vegetação herbácea ou lenhosa de porte baixo, sendo suas espécies adaptadas a suportar inundações periódicas.

De acordo com o Atlas Ambiental produzido pela SVMA em parceria com a FAPESP para o projeto BIOTA, na Cratera de Colônia, a flora é muito diferenciada, com formações campestres e floresta de várzea ocorrendo principalmente nos terrenos mal drenados (baixa diversidade arbórea e alta diversidade de epifitas); predomina formação de várzea, com espécies de campos dominadas por Gramineae e Xyperiaceae e entremeadas principalmente por Cyperaceae, Onagraceae, Eriocaulaceae, Pontederiaceae e Alismataceae. Nestas áreas ocorrem espécies interessantes de Araceae do gênero Urosphata. As florestas de várzeas possuem, normalmente, baixa diversidade de espécies arbóreas, ocorrendo muitas espécies da familia Myrtaceae, ipê amarelo de brejo (Tabebuia umbellata), branquilho (Sebastiania klostzschiana), entre outras. Nessas florestas de várzea destaca-se a grande diversidade de epífitas. Ocorrem várias famílias botânicas (Bromeliaceae, Piperaceae, Polipodiaceae, Gesneriaceae, Orchidaceae, Cactaceae) além de muitas briófitas (SVMA 1998).

Embora bastante ameaçada pela expansão dos loteamentos próximos, é possível presenciar, ainda nos limites da Cratera de Colônia, a Floresta ombrófila densa montana $\mathcal{e}$ alto montana primária ou secundária, que constitui a formação florestal mais desenvolvida da área da APA, dominada por árvores e com grande riqueza de espécies, apresentando pelo menos três estratos: superior, pouco denso e com indivíduos de altura entre 15 a 25 metros; intermediário, de alta densidade e constituida por indivíduos de 5 a 10 metros; inferior, com ervas e arbustos, além de palmeiras e fetos arborescentes de até 3 metros de altura. Essa formação exerce papel fundamental na estabilidade do solo, manutenção do manancial hídrico, da fauna e do clima da região, devendo servir como banco genético para repovoamentos futuros. (SVMA 1998). 


\subsection{Parelheiros em dados}

\subsubsection{Caracterização geral}

A região compreendida pela subprefeitura de Parelheiros localiza-se na parte sul do Município de São Paulo e estende-se por uma área de 35.000 hectares. Engloba os distritos de Marsilac e Parelheiros e sua área corresponde a $24 \%$ do território do Município, cuja autonomia administrativa foi adquirida a partir do ano de 2002 com a criação das Subprefeituras (PMSP 2004).

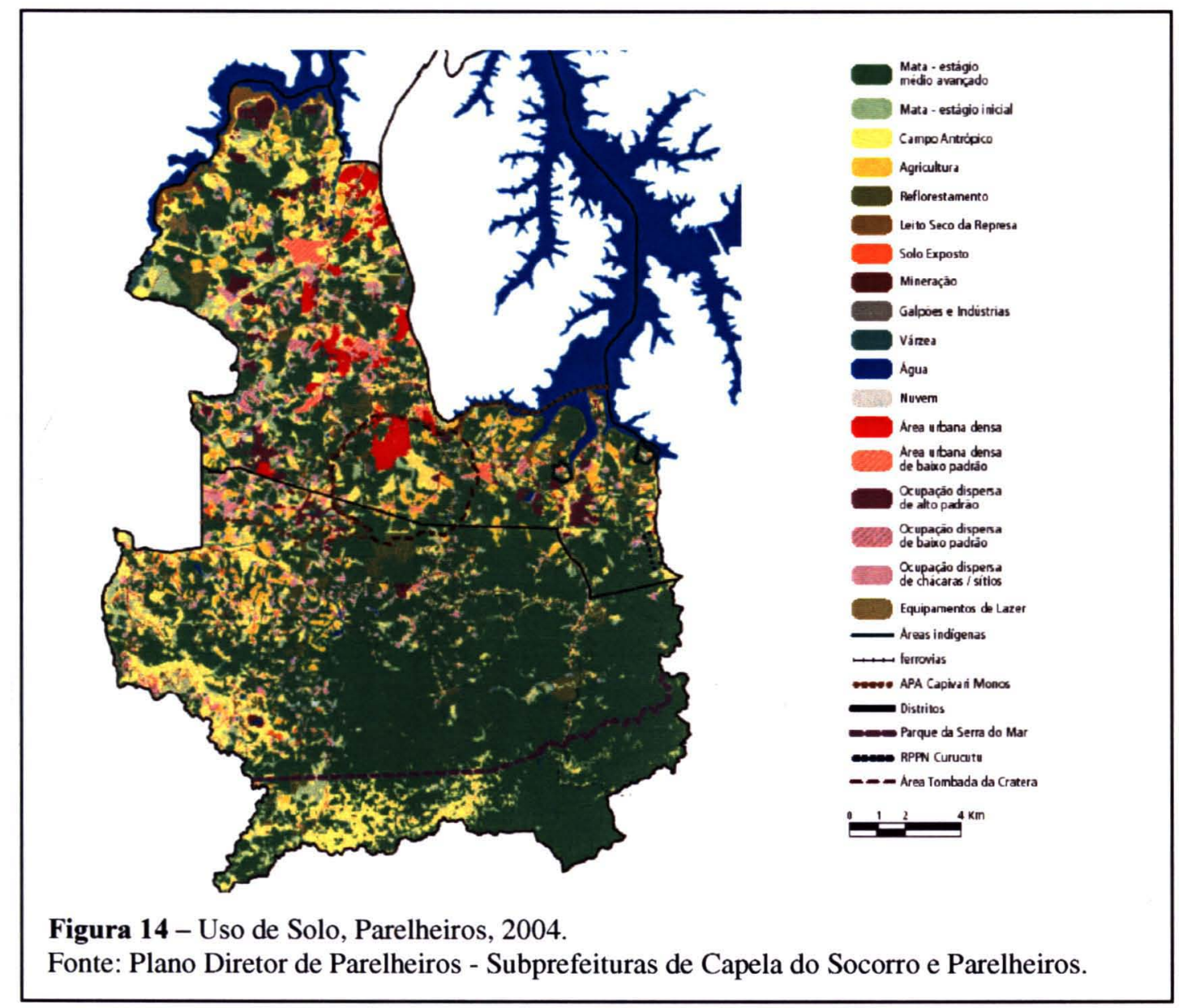

\subsubsection{Demografia}

O Censo do ano 2000 aponta uma população, na cidade de São Paulo, de 10.679.760 habitantes. Em comparação com o Censo de 1991, que apontava uma população de 9.610.659, houve uma taxa de crescimento de 0,8\% (SEADE 2004). Embora o crescimento da cidade já não aconteça da maneira vertiginosa como a que ocorreu na segunda metade do Século XX, a distribuição da população apresenta-se 
de forma diferenciada pelo território do município de São Paulo: enquanto que nas subprefeituras e distritos de Aricanduva, Lapa, Mooca, Pinheiros, Santana, Tucuruvi, Santo Amaro, Sé, Vila Maria, Vila Guilherme e Vila Mariana houve uma perda de população, as demais subprefeituras e distritos tais como, Butantã, Campo Limpo, Cidade Ademar, Cidade Tiradentes, Ermelino Matarazzo, Freguesia do Ó, Brasilândia, Guaianases, Parelheiros, Perus e Socorro vêm apresentando taxas de crescimento mais elevadas, o que evidencia um deslocamento da população dos bairros mais centrais para as franjas periféricas da cidade, tendência já observada no início da década de 1990.

Dentre as subprefeituras e distritos com as maiores taxas de crescimento anuais estão: Cidade Tiradentes com 6,9\%; Perus com 6,4\% e o distrito de Parelheiros com 6,0\%, que abarca a Cratera da Colônia, lócus da presente investigação (SEADE 2004).

A população absoluta da região compreendida pela subprefeitura de Parelheiros, de acordo com o Censo de 1991, era de 61.360 habitantes. Em 2004 um estudo divulgado pela Fundação SEADE revelou que em apenas 13 anos a população dessa região mais do que duplicou, o que significa uma preocupação bastante elevada em função da região se inserir quase que totalmente dentro da Área de Preservação Ambiental Capivari-Monos, onde encontram-se grande parte dos mananciais da cidade.

Tabela 1 - Densidade demográfica no Município de São Paulo (hab/ha) e na região da Subprefeitura de Parelheiros, Distrito de Parelheiros e Marsilac, em 2000.

\begin{tabular}{lccccc}
\hline Unidades Territoriais & $\begin{array}{c}\text { Área } \\
\text { Bruta (ha) }\end{array}$ & $\begin{array}{c}\text { Área Líquida } \\
\text { (ha) }\end{array}$ & $\begin{array}{c}\text { População } \\
\text { em 2000 }\end{array}$ & \multicolumn{2}{c}{$\begin{array}{c}\text { Densidade em } \\
\mathbf{2 0 0 0} \text { hab/ha }\end{array}$} \\
\cline { 5 - 6 } & & & & & \\
Bruta & Líquida \\
\hline MSP & $\mathbf{1 5 0 . 9 0 0}$ & $\mathbf{1 3 0 . 8 0 2 , 8}$ & $\mathbf{1 0 . 4 3 4 . 2 5 2}$ & $\mathbf{6 9 , 1 5}$ & $\mathbf{7 9 , 7 7}$ \\
Subprefeitura de Parelheiros & 35.350 & $30.507,8$ & 111.240 & 3,15 & 3,65 \\
Parelheiros & 15.350 & $14.429,1$ & 102.836 & 6,70 & 7,13 \\
Marsilac & 20.000 & $16.078,7$ & 8.404 & 0,42 & 0,52 \\
\hline
\end{tabular}

Fonte: IBGE, Censo Demográfico 2000.

(*) A área líquida foi obtida excluindo-se da área bruta: áreas de proteção ambiental, reservas florestais, represas, parques, clubes, cemitérios e aeroportos, segundo IBGE. 
Embora a população da região de Parelheiros tenha crescido acima da média verificada no município de São Paulo no mesmo período, a relação entre esse extenso território ocupado (35.000 hectares, dos quais $30 \mathrm{mil}$ correspondem a sua área líquida ${ }^{13}$ ) e o número absoluto da população existente resulta em baixa densidade demográfica, sendo menor que 1 hab/ha em Marsilac e de 7 hab/ha em Parelheiros. Essa taxa é inferior à média do município, que é de 79,8 habitantes por hectare. (Censo Demográfico de 2000).

Tabela 2 - População Total e Taxa Anual de Crescimento Populacional, no Município de São Paulo e Subprefeituras de Vila Mariana, Pinheiros, Parelheiros e Cidade Tiradentes, no período de 1991-2004.

\begin{tabular}{lccc}
\hline $\begin{array}{l}\text { Subprefeituras e } \\
\text { Distritos }\end{array}$ & \multicolumn{2}{c}{ População Residente } & $\begin{array}{c}\text { Taxa Anual de Crescimento } \\
\text { 1991-2004 (em \%) }\end{array}$ \\
\cline { 2 - 4 } MSP & $\mathbf{1 9 9 1}$ & $\mathbf{2 0 0 4}$ & $\mathbf{0 , 8}$ \\
Vila Mariana & $\mathbf{9 . 6 1 0 . 6 5 9}$ & $\mathbf{1 0 . 6 7 9 . 7 6 0}$ & $-0,7$ \\
Pinheiros & 335.513 & 304.858 & $-2,2$ \\
Parelheiros & 338.369 & 253.895 & 6,0 \\
Cidade Tiradentes & 61.360 & 130.587 & 6,9 \\
\hline
\end{tabular}

Fonte: IBGE. Censo Demográfico 1991 e 2000; Fundação Seade, 2004.

Nota: População em $1^{\circ}$ de julho.

Um aspecto que agrava ainda mais os problemas socioambientais da região de Parelheiros consiste na elevada concentração de população jovem. Mais da metade da população total da região é composta por indivíduos com menos de 25 anos, esse indicador aponta para a necessidade, por parte dos governantes, da priorização de políticas públicas que preservem e possibilitem um futuro mais promissor para esses jovens, contrapondo-se à opção oferecida pela delinqüência e pela violência.

\footnotetext{
13 A área líquida é obtida excluindo-se da área bruta as áreas de proteção ambiental, reservas florestais, represas, parques, clubes, cemitérios, aeroportos. ( IBGE, Censo Demográfico de 2000)
} 
Tabela 3 - População total, por grupos de idade, no Município de São Paulo e Subprefeituras de Vila Mariana, Pinheiros, Parelheiros e Cidade Tiradentes, em números absolutos, 2004.

\begin{tabular}{lcccccc}
\hline Subprefeituras e Distritos & $\begin{array}{c}\mathbf{0} \text { a 9 } \\
\text { anos }\end{array}$ & $\begin{array}{c}\mathbf{1 0} \text { a } 17 \\
\text { anos }\end{array}$ & $\begin{array}{c}\mathbf{1 8} \text { a } \mathbf{2 4} \\
\text { anos }\end{array}$ & $\begin{array}{c}\mathbf{2 5} \text { a 59 } \\
\text { anos }\end{array}$ & $\begin{array}{c}\mathbf{6 0} \text { anos } \\
\text { e mais }\end{array}$ & $\begin{array}{c}\text { Pop. } \\
\text { total }\end{array}$ \\
\hline MSP & $\mathbf{1 . 7 8 7 . 9 6 2}$ & $\mathbf{1 . 3 3 8 . 7 6 3}$ & $\mathbf{1 . 3 2 0 . 3 3 9}$ & $\mathbf{5 . 1 6 9 . 5 6 8}$ & $\mathbf{1 . 0 6 3 . 1 2 8}$ & $\mathbf{1 0 . 6 7 9 . 7 6 0}$ \\
Vila Mariana & 27.278 & 25.665 & 32.642 & 163.722 & 55.551 & 304.858 \\
Pinheiros & 20.007 & 18.895 & 27.289 & 135.563 & 52.141 & 253.895 \\
Parelheiros & 30.928 & 19.967 & 16.717 & 57.122 & 5.853 & 130.587 \\
Cidade Tiradentes & 52.513 & 35.577 & 29.180 & 103.902 & 8.434 & 229.606 \\
\hline
\end{tabular}

Fonte: Fundação Seade, 2004.

\subsubsection{Saúde}

No tocante aos indicadores de saúde, percebe-se que, nos últimos anos, as taxas de mortalidade vêm decrescendo na Região Metropolitana de São Paulo; conseqüentemente, a esperança de vida na região vem aumentando, atingindo os 70 anos de idade. Esse fenômeno foi resultante, em grande parte, do declínio das taxas de mortalidade infantil que, embora tenham diminuído, como pode ser percebido na subprefeitura de Parelheiros, ainda não podem ser consideradas satisfatórias, especialmente se forem comparadas com centros urbanos de países desenvolvidos. Porém, evidenciam-se os resultados positivos de políticas públicas de saúde pública e saneamento básico, implementadas na RMSP. Estimulados pela medicina preventiva, difundiram-se processos de vacinação, melhorou-se a qualidade da água e aumentouse a rede de coleta de esgotos. Essas medidas foram essenciais para a redução dos óbitos, notadamente de crianças, as mais afetadas pelos problemas causados pelo ambiente. 

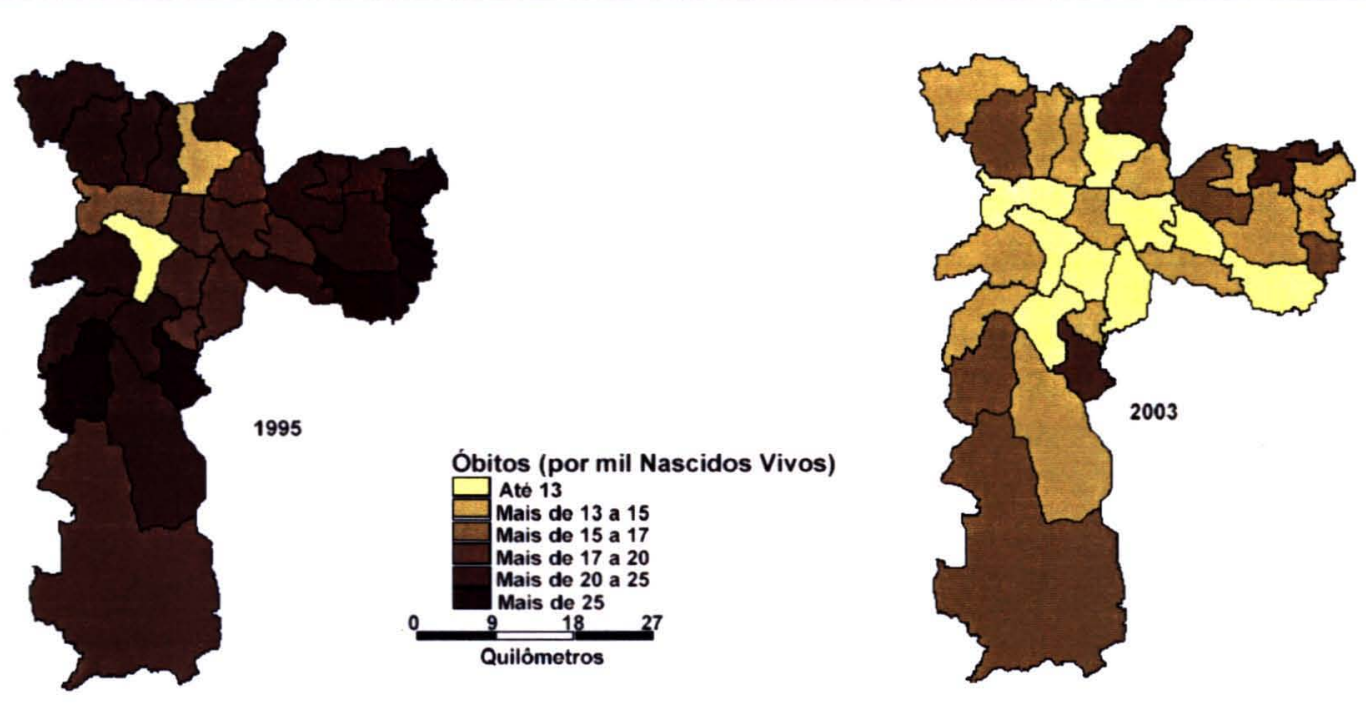

Figura 15 - Taxa de Mortalidade Infantil, segundo Subprefeituras do Município de São Paulo, no período de 1995 - 2003. Fonte: Fundação SEADE. Disponível em http://www.seade.gov.br/produtos/msp/sau/mortinf_m001.pdf

No que se refere à mortalidade infantil (MI), embora essa taxa tenha decaído na subprefeitura de Parelheiros (de 19,84 por mil nascidos vivos em 1995 para 16,01 em 2004), acompanhado a tendência de outras localidades, o índice de mortalidade neonatal (óbitos até 27 dias de vida) que era de 10,44 por mil nascidos vivos, subiu para 11,83 em 2004. Tal aumento sugere um agravamento da situação de saúde, uma vez que a mortalidade neonatal é um indicador bastante sensível às condições econômico-sociais e sanitárias, e o seu aumento pode refletir condições ambientais hostis e, principalmente, deficiências na qualidade de assistência hospitalar. 
Tabela 4 - Taxa de Mortalidade Infantil, Neonatal e Pós-Neonatal, por mil nascidos vivos, no Município de São Paulo e nas Subprefeituras de Vila Mariana, Pinheiros, Parelheiros e Cidade Tiradentes, em 1995 e 2003.

\begin{tabular}{lcccccc}
\hline & \multicolumn{4}{c}{ Mortalidade Infantil } \\
\cline { 2 - 7 } Municípios e & \multicolumn{3}{c}{$\mathbf{1 9 9 5}$} & \multicolumn{4}{c}{$\mathbf{2 0 0 3}$} \\
\cline { 2 - 7 } Subprefeituras & \multicolumn{3}{c}{ Pós- } \\
MSP & Neonatal & Neonatal & TMI & Neonatal Neonatal & TMI \\
\cline { 2 - 7 } Vila Mariana & $\mathbf{1 4 , 8 6}$ & $\mathbf{8 , 6 0}$ & $\mathbf{2 3 , 4 6}$ & $\mathbf{9 , 5 7}$ & $\mathbf{4 , 6 6}$ & $\mathbf{1 4 , 2 3}$ \\
Pinheiros & 11,67 & 5,62 & 17,28 & 5,49 & 2,09 & 7,59 \\
Parelheiros & 9,20 & 3,58 & 12,77 & 6,21 & 2,07 & 8,28 \\
Cidade Tiradentes & 10,44 & 9,40 & 19,84 & 11,83 & 4,18 & 16,01 \\
\hline & 17,77 & 15,18 & 32,95 & 10,66 & 5,89 & 16,55 \\
\hline
\end{tabular}

Fonte: Fundação Seade, 2004.

Outro indicador bastante importante para os estudos na área da saúde é o que se refere à mortalidade por meio de dois grupos de causas de morte: as evitáveis e as não-evitáveis. As causas evitáveis seriam aquelas passíveis de atuação por meio de políticas públicas de planejamento em saúde, tais como: vacinação, diagnóstico precoce e tratamento médico de boa qualidade, associadas ao grau de esclarecimento e educação, à renda familiar, à nutrição, à segurança pública e, ainda, à eficiência do sistema de saúde. As não-evitáveis seriam aquelas mais dependentes dos avanços científicos, como as doenças crônico-degenerativas.

Dentre as mortes por causas evitáveis destaca-se no Subdistrito de Parelheiros, o alto índice da mortalidade de homens por causas externas. No triênio 2000-2002, observou-se quase o dobro da mortalidade atribuída às causas externas verificada no município de São Paulo (Tabela 5).

A Tabela 6, detalhada em subgrupos de causas, apresenta novamente o segmento de homens como o mais atingido, no caso da subprefeitura de Parelheiros, pela mortalidade masculina provocada por causas externas. Esses dados evidencia o aumento extraordinário das taxas de mortalidade masculina ocasionada por agressões e homicídios na Subprefeitura de Parelheiros, em comparação com as demais regiões da cidade. No triênio 2000-2002, essa incidência ultrapassou o dobro da taxa verificada no município de São Paulo como um todo. 
Observa-se também a grande diferença, resultante da exclusão sócio-espacial e econômica, entre as Subprefeituras de Parelheiros (Zona Sul) e Cidade Tiradentes (Zona Leste), quando comparadas às de Pinheiros (Zona Oeste) e Vila Mariana (Zona Sul), esses últimos, habitados por estratos de maior poder aquisitivo do município de São Paulo.

Tabela 5 - Distribuição dos óbitos de homens e mulheres, por capítulos da CID*, no Município de São Paulo e Subprefeituras de Vila Mariana, Pinheiros, Parelheiros e Cidade Tiradentes no Triênio 2000/2002, em porcentagem.

\begin{tabular}{lccccccccc}
\hline & \multicolumn{10}{c}{ Capítulos da CID $^{*}$} \\
\hline Homens & $\mathbf{1}$ & $\mathbf{2}$ & $\mathbf{3}$ & $\mathbf{4}$ & $\mathbf{5}$ & $\mathbf{6}$ & $\mathbf{7}$ & $\mathbf{8}$ & $\mathbf{9}$ \\
\hline MSP & $\mathbf{2 8 , 7}$ & $\mathbf{2 1 , 8}$ & $\mathbf{1 5 , 6}$ & $\mathbf{1 0 , 1}$ & $\mathbf{6 , 1}$ & $\mathbf{5 , 2}$ & $\mathbf{3 , 4}$ & $\mathbf{1 , 2}$ & $\mathbf{7 , 9}$ \\
Vila Mariana & 34,0 & 7,9 & 23,7 & 13,9 & 6,0 & 3,4 & 3,0 & 1,1 & 7,1 \\
Pinheiros & 33,5 & 7,0 & 26,2 & 12,4 & 5,0 & 3,8 & 3,8 & 1,4 & 7,0 \\
Parelheiros & 19,3 & 42,6 & 7,9 & 7,7 & 4,8 & 5,1 & 2,5 & 1,2 & 8,9 \\
Cidade Tiradentes & 21,9 & 38,1 & $\mathbf{8 , 2}$ & 7,3 & 5,5 & 6,5 & 2,6 & 0,9 & 9,0 \\
\hline Mulheres & & & & & & & & & \\
\hline MSP & $\mathbf{3 8 , 2}$ & $\mathbf{1 9 , 6}$ & $\mathbf{1 2 , 2}$ & $\mathbf{5 , 6}$ & $\mathbf{4 , 5}$ & $\mathbf{4 , 5}$ & $\mathbf{4 , 1}$ & $\mathbf{1 , 1}$ & $\mathbf{1 0 , 1}$ \\
Vila Mariana & 37,4 & 23,6 & 13,7 & 4,7 & 2,8 & 4,2 & 2,6 & 1,2 & 9,7 \\
Pinheiros & 38,2 & 25,2 & 13,5 & 3,6 & 3,2 & 4,5 & 1,9 & 1,1 & 8,7 \\
Parelheiros & 35,1 & 17,6 & 9,8 & 3,9 & 8,3 & 4,4 & 4,4 & 0,9 & 15,5 \\
Cidade Tiradentes & 34,9 & 14,3 & 10,4 & 7,2 & 6,7 & 3,7 & 6,4 & 1,4 & 15,1 \\
\hline
\end{tabular}

Legenda: (*) CID - Classificação Internacional de Doenças, décima revisão. (1) Doenças do Aparelho Circulatório; (2) Causas Externas; (3) Neoplasias; (4) Doenças do Aparelho Respiratório; (5) Doenças do Aparelho Digestivo; (6) Doenças Infecciosas e Parasitárias; (7) Doenças Endócrinas; (8) Causas Mal Definidas; (9) Demais Causas.

Fonte: Fundação Seade, 2004. 
Tabela 6 - Taxas de mortalidade de homens e mulheres, por 100 mil habitantes, por causas externas, no Município de São Paulo e Subprefeituras de Vila Mariana, Pinheiros, Parelheiros e Cidade Tiradentes no triênio 2000/2002.

\begin{tabular}{|c|c|c|c|c|c|c|}
\hline $\begin{array}{l}\text { Sub- } \\
\text { prefeitura }\end{array}$ & $\begin{array}{r}\text { Acidentes } \\
\text { de Trânsito }\end{array}$ & $\begin{array}{r}\text { Outros } \\
\text { Acidentes }\end{array}$ & Suicídios & $\begin{array}{l}\text { Agressões / } \\
\text { Homicídios }\end{array}$ & $\begin{array}{r}\text { Outras Causas } \\
\text { Externas } \\
\end{array}$ & Total \\
\hline \multicolumn{7}{|l|}{ Homens } \\
\hline MSP & 19,0 & 21,4 & 6,0 & 106,8 & 14,5 & 167,7 \\
\hline Cid.Tiradentes & 17,1 & 12,9 & 2,8 & 154,9 & 13,6 & 201,3 \\
\hline Parelheiros & 19,1 & 23,1 & 5,8 & 215,2 & 15,6 & 278,8 \\
\hline Pinheiros & 14,9 & 10,0 & 7,7 & 21,4 & 11,2 & 65,2 \\
\hline Vila Mariana & 15,7 & 14,2 & 5,8 & 24,8 & 8,2 & 68,7 \\
\hline \multicolumn{7}{|l|}{ Mulheres } \\
\hline MSP & 4,8 & 5,6 & 1,7 & 7,0 & 4,1 & 23,3 \\
\hline Cid.Tiradentes & 1,9 & 3,5 & 1,9 & 10,3 & 1,3 & 19,0 \\
\hline Parelheiros & 5,2 & 6,9 & 1,2 & 11,0 & 1,7 & 26,0 \\
\hline Pinheiros & 6,2 & 7,0 & 3,7 & 1,5 & 6,6 & 25,0 \\
\hline Vila Mariana & 3,5 & 6,0 & 3,7 & 3,7 & 3,9 & 20,6 \\
\hline
\end{tabular}

Fonte: Fundação Seade, 2004.

\subsubsection{Vulnerabilidade Juvenil}

No contexto do projeto Fábrica de Cultura, desenvolvido pela Secretaria de Estado da Cultura, no município de São Paulo, foi criado o índice de vulnerabilidade juvenil (IVJ), cuja função central é auxiliar na escolha de áreas de intervenção, ou no caso, os 96 distritos administrativos do município. A escolha do termo "vulnerabilidade juvenil" foi uma opção àqueles utilizados de forma mais recorrente, como "adolescentes em situação de risco" ou "adolescentes em situação de exclusão social", que, na ótica do projeto, poderiam distorcer o entendimento da grave e complexa problemática em que estão envolvidos os adolescentes. A despeito das controvérsias acerca do termo mais adequado, o objetivo principal no desenvolvimento desse índice foi demonstrar que políticas eficientes para jovens seriam aquelas que, de alguma forma, contribuíssem para que este período natural de turbulência transcorresse de forma a impedir ou minimizar escorregões para a transgressão. O IVJ foi obtido a partir de um modelo de análise fatorial e para a sua composição foram consideradas variáveis tais como, os níveis de crescimento populacional, presença de jovens entre a população distrital, freqüência escolar, gravidez e violência entre os jovens e adolescentes residentes no local. Este indicador varia em uma escala de 0 a 100 pontos, em que o zero representa o distrito com menor vulnerabilidade e 100 o de maior (SEADE 2004). 
A subprefeitura de Parelheiros está representada no Grupo 5: com mais de 65 pontos, o que significa o grupo com o maior índice de vulnerabilidade juvenil da RMSP, o que vem corroborar as diversas vozes que emergiram na Cratera da Colônia.

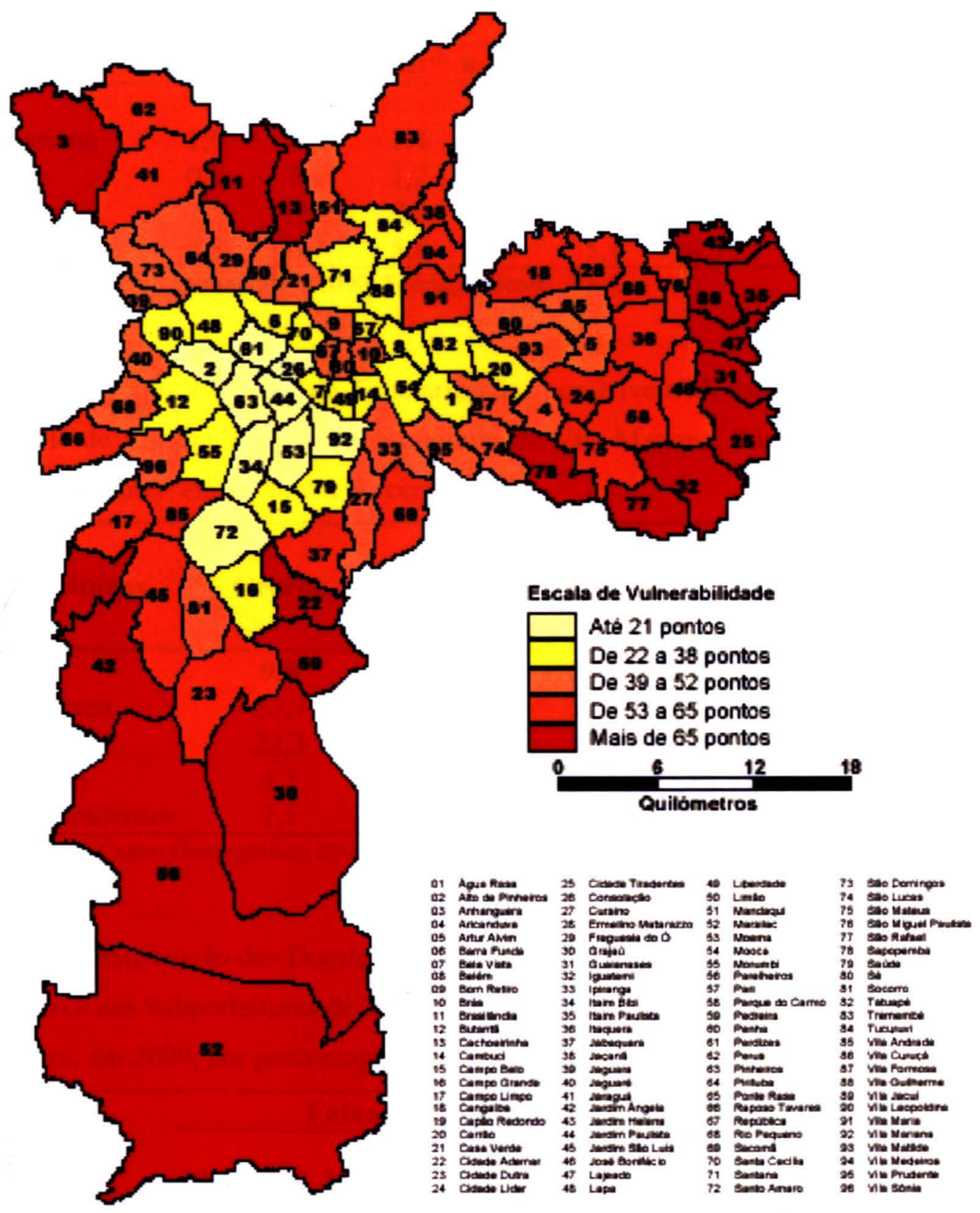

Fonte: Fundegabo Seade.

(1) O Indice de Wulnerabilidade Juvenill (IVJ), criado pala Fundaçeto Seede, e calculado a partir da identificaclo dos fatores socioeconomicos e demográlicos potencialmente capazes de aletar a vide dos adolescentes e jovens residentes nos distritos da capital. O NJ varia em uma escala de 0 a 100 pontos, em que o zero represente o tistrito com a menor vinerabilidade $100 \mathrm{com}$ a malor. Este indice pode ser resumido em cinco categorias, que agrupam os 83 distuttos da cidade segundo nhels de vilnerabillidade: att 21 pontos (vulnerabillidade muito baixa); de 22 a 38 pontos (balxa vulnerabillidade); de 39 a 52 pontos (media vilnerabillidade); de 53 a 65 (alta vilnerabilidada) e mais de 65 pontos (vilnerabilidade multo alta).

Figura 16 - Grupos de Vulnerabilidade Juvenil, segundo Distritos do Município de São Paulo, SP, 2000. Fonte: Fundação SEADE. Disponível em http://www.seade.gov.br/produtos/msp/sau/mortinf_m001.pdf 


\subsubsection{Educação e Renda}

Tabela 7 - Taxas de Analfabetismo da População de 15 Anos e Mais, por Sexo e Raça/Cor, no Município de Sào Paulo e nas Subprefeituras de Vila Mariana, Pinheiros, Parelheiros e Cidade Tiradentes em 2000, em porcentagem.

\begin{tabular}{|c|c|c|c|c|c|c|c|c|c|}
\hline \multirow[t]{2}{*}{ Subprefeituras } & \multicolumn{3}{|c|}{ Mulheres } & \multicolumn{3}{|c|}{ Homens } & \multicolumn{3}{|c|}{ Total } \\
\hline & Brancas & Negras (1) & Total $^{(2)}$ & Brancos & Negros ${ }^{(1)}$ & Total $^{(2)}$ & Brancos & Negros ${ }^{(1)}$ & Total $^{(2)}$ \\
\hline \multicolumn{10}{|l|}{ PMSP } \\
\hline Vila Mariana & 1,0 & 5,1 & 1,4 & 0,6 & -3 & 0,8 & 0,9 & 4,3 & 1,1 \\
\hline Pinheiros & 0,8 & 5,6 & 1,2 & -3 & -3 & 0,5 & 0,7 & 4,6 & 0,9 \\
\hline Parelheiros & 7,5 & 12,2 & 9,9 & 5,3 & 9,5 & 7,7 & 6,5 & 10,8 & 8,8 \\
\hline Cid. Tiradentes & 4,8 & 6,7 & 5,8 & 3,9 & 5,1 & 4,5 & 4,4 & 5,9 & 5,2 \\
\hline
\end{tabular}

Fonte: IBGE. Censo Demográfico 2000; Fundaçào Seade, 2004.

Tabela 8 - Taxas Líquidas de Escolarização, por Níveis/Modalidade de Ensino, no Município de São Paulo e nas Subprefeituras de Vila Mariana, Pinheiros, Parelheiros e Cidade Tiradentes, em 2000 , em porcentagem.

\begin{tabular}{lccccc} 
Subprefeituras & Creche & Pré-Escola & $\begin{array}{c}\text { Educação } \\
\text { Infantil }\end{array}$ & $\begin{array}{c}\text { Ensino } \\
\text { Fundamental }\end{array}$ & $\begin{array}{c}\text { Ensino } \\
\text { Médio }\end{array}$ \\
\hline PMSP & $\mathbf{9 , 6}$ & $\mathbf{5 0 , 4}$ & $\mathbf{3 0 , 2}$ & $\mathbf{9 3 , 3}$ & $\mathbf{5 4 , 4}$ \\
Vila Mariana & 23,7 & 73,5 & 53,5 & 95,6 & 75,2 \\
Pinheiros & 22,3 & 74,8 & 55,5 & 95,2 & 74,9 \\
Parelheiros & 4,5 & 27,7 & 16,5 & 89,0 & 41,5 \\
Cidade Tiradentes & 7,5 & 61,4 & 32,0 & 95,2 & 44,6 \\
\hline
\end{tabular}

Fonte: IBGE. Censo Demográfico 2000; Fundação Seade, 2004.

Tabela 9 - Distribuição dos Domicílios, por Faixas de Renda Familiar, no Município de Sâo Paulo e nas Subprefeituras de Vila Mariana, Pinheiros, Parelheiros e Cidade Tiradentes, em 2000 , por porcentagem.

\begin{tabular}{lcccccc}
\hline & \multicolumn{5}{c}{ Faixas de Renda em Salários Mínimos (SM) } \\
\cline { 2 - 7 } Distritos & $\begin{array}{c}\text { De 2 a } \\
\text { Menos de 2 } 2\end{array}$ & $\begin{array}{c}\text { De 5 a } \\
\text { Menos de 5 }\end{array}$ & $\begin{array}{c}\text { De 10 a } \\
\text { Menos de } \\
\text { SM }\end{array}$ & $\begin{array}{c}\text { De 15 a } \\
\text { Menos de } \\
\text { 15 SM }\end{array}$ & $\begin{array}{c}\text { Menos de } \\
\text { 25 SM }\end{array}$ & $\begin{array}{c}\text { De 25 SM e } \\
\text { Mais }\end{array}$ \\
\hline PMSP & $\mathbf{1 3 , 3 0}$ & $\mathbf{2 4 , 3 9}$ & $\mathbf{2 5 , 9 7}$ & $\mathbf{1 1 , 2 9}$ & $\mathbf{1 0 , 9 8}$ & $\mathbf{1 4 , 0 6}$ \\
Vila Mariana & 2,87 & 7,03 & 13,69 & 9,90 & 17,47 & 49,05 \\
Pinheiros & 3,77 & 5,98 & 14,34 & 9,60 & 16,53 & 49,79 \\
Parelheiros & 26,06 & 38,16 & 25,79 & 6,15 & 2,83 & 1,01 \\
Cidade Tiradentes & 20,47 & 36,92 & 31,23 & 7,53 & 3,08 & 0,76 \\
\hline
\end{tabular}

Fonte: IBGE; Fundação Seade. Nota: Excluindo-se os domicílios cuja espécie é do tipo coletivo.

Salário mínimo de referência do Censo 2000: R $\$ 151,00$. 


\subsubsection{Cultura e Lazer}

Tabela 10 - Equipamentos Culturais, por Tipo, no Município de São Paulo e Subprefeituras de Cidade Tiradentes, Parelheiros, Pinheiros e Vila Mariana, em 2002.

\begin{tabular}{lcccccc}
\hline Subprefeituras & $\begin{array}{c}\text { Salas de } \\
\text { Cinema }\end{array}$ & $\begin{array}{c}\text { Salas de } \\
\text { Teatro }\end{array}$ & $\begin{array}{c}\text { Casas de } \\
\text { Cultura }\end{array}$ & $\begin{array}{c}\text { Centros } \\
\text { Culturais }\end{array}$ & Museus & $\begin{array}{c}\text { Esp. e Of. } \\
\text { Culturais }\end{array}$ \\
\hline MSP & $\mathbf{2 3 5}$ & $\mathbf{1 2 1}$ & $\mathbf{1 2}$ & $\mathbf{3 3}$ & $\mathbf{7 2}$ & $\mathbf{3 5}$ \\
Cidade Tiradentes & - & - & - & - & - & - \\
Parelheiros & - & - & - & - & - & - \\
Pinheiros & 40 & 14 & - & 8 & 8 & 7 \\
Vila Mariana & 17 & 4 & - & 3 & 4 & 3 \\
\hline
\end{tabular}

Fonte: Fundação Seade, 2004. Guia Cultural do Estado de Sào Paulo.

\subsection{Aspectos políticos-administrativos}

Desde 1996 a associação de moradores que administra o condomínio denomina-se ACHAVE - Associação Comunitária Habitacional Vargem Grande, cuja diretoria tinha sido eleita em fevereiro de 2004, por ocasião do estudo de campo.

A abertura do loteamento havia sido detectada pela fiscalização pública ainda no início da ocupação, no final da década de 1980, gerando uma série de medidas administrativas e legais, tanto por parte da Prefeitura de São Paulo como pelo Governo do Estado, todas infrutíferas. A presidente da UNIFAG na época, chegou a ser condenada em primeira instância, mas recorreu e, ao final, foi absolvida. Como justificativa alegou "se o próprio Estado constrói um presidio contrariando a legislação vigente, por que familias carentes não poderiam ocupar a área?" Sua alegação foi acolhida pelo juiz (GAFFO 1998).

Desde o início da ocupação, a população de moradores da Cratera vem aumentando vertiginosamente. Segundo uma das entrevistadas, em 1995 houve na Cratera um grande afluxo populacional, oriundo de desapropriação de área da Favela das Águas Espraiadas, também na zona sul do município, o que foi confirmado pela Associação dos Moradores. 
O Condomínio Vargem Grande possui uma população estimada, em 2004, de 40 mil pessoas, conforme dados da ACHAVE; duas escolas estaduais e uma escola municipal, esta última construída pelos próprios associados em mutirão e, posteriormente, encampada pela prefeitura. O condomínio possui ainda três creches.

No tocante às ações e serviços de saúde, o Condomínio conta com um posto de saúde, que dispõe do Programa de Saúde da Família - PSF, em parceria com a Universidade Santo Amaro - UNISA; o programa opera com cinco equipes médicas. Os casos graves e de pronto atendimento são encaminhados ao Hospital do Grajaú e ao Pronto Socorro de Parelheiros, os mais próximos da Cratera. Há quatro estabelecimentos farmacêuticos dentro do Condomínio.

Quanto ao aspecto da organização comunitária, há no Condomínio uma rádio comunitária denominada Rádio Achave, com alcance a grande parte da Área de Proteção Ambiental - APA e uma associação de mulheres, a AMUVE- Associação de Mulheres de Vargem Grande. Há ainda no Condomínio uma igreja católica e cerca de vinte igrejas evangélicas.

O condomínio é servido por linha de ônibus regular, que segundo os entrevistados, demora cerca de três horas para chegar ao centro de São Paulo.

É em torno da Associação que se congrega grande parte da vida comunitária do Condomínio. A ACHAVE, entidade decorrente da organização UNIFAG, tem como objetivo "administrar o condomínio, representar os moradores do Condomínio Habitacional Vargem Grande, promover o envolvimento da comunidade nas discussões sobre o gerenciamento da Área de Proteção Ambiental Capivari - Monos, da qual o Condomínio faz parte, e manter o espaço dentro de valores estéticos e ambientais".

A diretoria é composta por presidente, vice-presidente e diretores, eleitos a cada quatro anos pelos moradores que estão em dia com suas obrigações financeiras. Em fevereiro de 2004 aconteceu a eleição da nova diretoria da ACHAVE, sendo que o então presidente da Associação foi reconduzido ao cargo. 

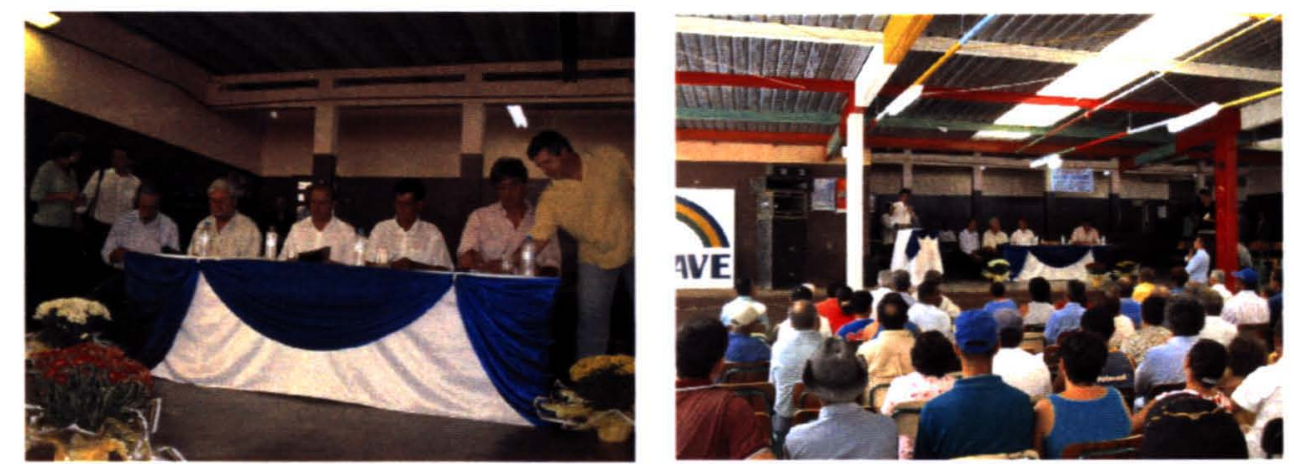

Figura 17 - Posse da Diretoria da ACHAVE em Março de 2004 com a presença do Governador do Estado de São Paulo, Sr. Geraldo Alckmin.

Cabe destacar que a posse da nova diretoria aconteceu em 08 de março de 2004, com grande participação da comunidade local e contando, ainda, com a presença do representante da subprefeitura de Parelheiros e com a presença do Senhor Governador do Estado de São Paulo, que permaneceu no local por quase duas horas, ocasião em que, além de fazer um pequeno discurso, também atendeu a todos que $\mathrm{o}$ assediavam para fotos e cumprimentos.

\subsection{Outras entidades organizadas na Cratera da Colônia}

\subsubsection{Radio Comunitária ACHAVE}

A Rádio Comunitária Achave constitui uma importante forma de participação, informação e de educação ambiental dos moradores da comunidade da Cratera da Colônia. É por meio da Rádio que são feitas convocações para assembléias, para reuniões comunitárias e é feita ainda a divulgação dos cursos e eventos que acontecem no lugar.

Em sua programação diária, encontram-se desde programas de música variada (sertaneja, forró), a programas mais voltados especialmente ao público feminino, veiculadas no período da tarde. 
Logo pela manhã acontece o Programa "Ecologia e Educação Ambiental”, conduzido pelo presidente da Associação Comunitária. Segundo o seu condutor, o programa se assemelha a uma revista, onde o carro chefe é a "divulgação de uma nova perspectiva de envolvimento dos seres humanos com a natureza". Para a elaboração do programa, não há uma pauta construída com planejamento e antecedência, mas "os assuntos vão surgindo de acordo com as necessidades da comunidade, da associação e muitos assuntos debatidos no programa são inspirados em noticias divulgadas pelos veiculos da grande imprensa tais como jornais, televisão e nos cursos de educação ambiental que a gente freqüenta", diz o radialista. A revista "Terra" da Editora Abril também foi citada como fonte de inspiração para a elaboração da pauta do programa. Como o programa é transmitido ao vivo, também há espaço para respostas a perguntas dirigidas pelos ouvintes.

Os patrocinadores dos programas são os pequenos comércios da região, tais como pequenos supermercados, farmácias, casas de comércio de material de construção, e outros.

Em meio à programação diária podem-se ouvir mensagens convocando os ouvintes para uma conscientização ambiental, tais como: "Radio Achave 100\% ecológica", além de "dicas" de alimentação, posturas recomendáveis à preservação da natureza e "dicas" para a manutenção da saúde.

A Rádio Comunitária exerce, ainda, um importante papel na organização cultural na Cratera, por meio das festas comemorativas que promove e divulga, além de grandes shows com artistas de expressão nacional.

\subsubsection{AMUVE - Associação de Mulheres de Vargem Grande}

A Associação de Mulheres de Vargem Grande é uma organização da sociedade civil (OSC), que tem como objetivo atender às crianças cujas mães trabalham fora. 
A AMUVE, por meio de parcerias com ONGs vem promovendo cursos de danças para os jovens e oficinas de reciclagem para crianças e jovens.
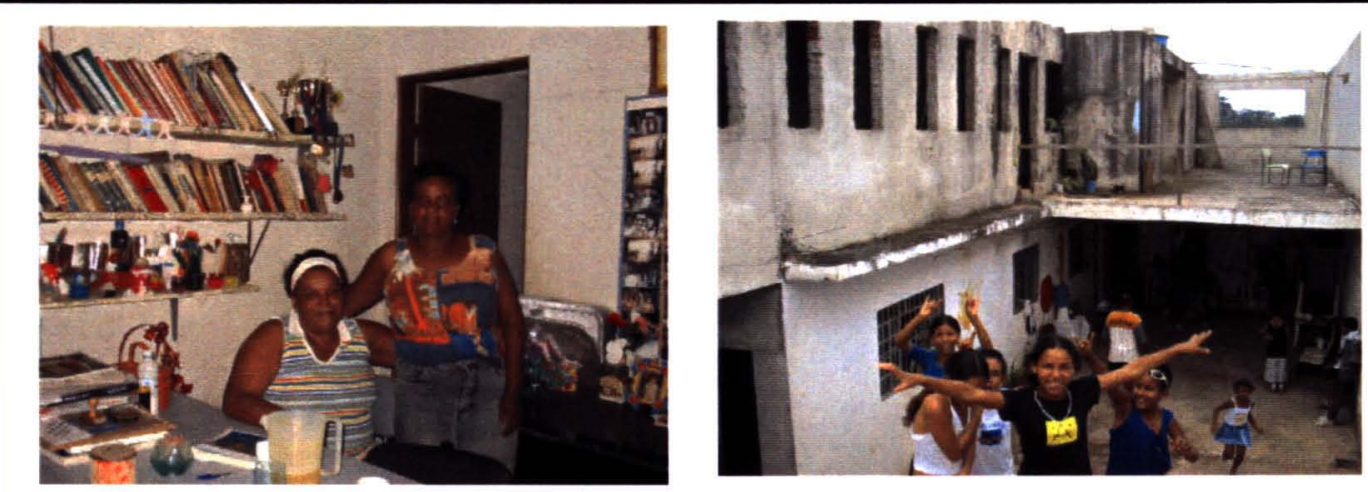

Figura 18 - Sede da Associação de Mulheres de Vargem Grande.

Uma outra entidade com forte presença na comunidade é o Lar Raio de Sol. Foi criado por membros da comunidade com o objetivo de atender ao grande número de crianças da região, uma vez que, no início de suas atividades, ainda não havia nenhuma creche que atendesse as crianças da comunidade. A partir do ano de 2004, o Lar Raio de Sol passou a contar com a parceria da Subprefeitura de Parelheiros. 


\section{CAPÍTULO 5}

\section{RESULTADOS E DISCUSSÃO}

"Entregamos aqui os depoimentos que homens e mulheres nos confiaram a propósito de sua existência e de sua dificuldade de viver. Organizamolos e os apresentamos com o objetivo de conseguir do leitor que lhes conceda um olhar tão compreensivo quanto o que as exigências do método científico nos impõem e nos permitem conceder-lhes". (BOURDIEU 1998, p.9). 
De acordo com Bourdieu, no livro "A Miséria do Mundo", como não experimentar, de fato, um sentimento de inquietação no momento de tornar públicas conversas privadas, confidências recolhidas numa relação de confiança? É justamente esse sentimento que povoa a mente e o coração do pesquisador no momento de trazer os depoimentos dos interlocutores que aceitaram confiar-lhe o uso que seria feito destes.

Apoiando-se no pensamento acima, adotou-se uma forma mista quanto à identificação dos entrevistados e entrevistadas. Conforme acordado previamente com os depoentes, foram respeitados seus desejos de não serem identificados. Somente optou-se por identificar aqueles cujas opiniões, idéias, lembranças se constituíram em agentes históricos, tanto dos grupos e instituições a qual pertencem.

Retomando brevemente a discussão sobre a questão ambiental, introduzida no capítulo 1, partiu-se do pressuposto que focalizar os discursos e práticas, sobre os vários temas, possibilita a reflexão sobre as transformações na forma de entender as subjetividades contemporâneas e as relações sociais que são estabelecidas nesse contexto. Esse pressuposto se sustenta nas considerações a seguir:

Primeiramente cada sociedade, em cada momento histórico, define o que é convencionado como questão ambiental. Considera-se não apenas aspectos reais, objetivos no sentido de que esses aspectos podem ser medidos e tornados visíveis e, portanto objetos de cálculo e probabilidades, mas também que tais aspectos são produto da experiência de pessoas, a partir de situações subjetivas.

A questão ambiental é uma construção social e, nessa medida, permite entender o modelo de sociedade que orienta essa construção e as práticas que a sustentam.

Por último, ao estudar a questão ambiental numa dada sociedade ou comunidade, busca-se entender como são estabelecidas as relações entre aqueles que definem e implementam as ações de controle, sejam essas ações individuais ou coletivas, e os sujeitos dessas ações de controle.

Compreende-se, dessa maneira, que a problemática ambiental é um fenômeno socialmente situado, e que as noções sobre os problemas, decorrentes dessa 
problemática, são objetivadas nas práticas institucionalizadas estabelecidas para regular as relações entre as pessoas. Essas práticas, institucionalizadas em formas de controle, são permanentemente negociadas, sendo permeadas por valores e posições políticas que podem ser estudadas a partir dos posicionamentos das pessoas nos processos de interação social.

Para tanto, buscou-se compreender as possibilidades de dar sentido à questão socioambiental, na Cratera da Colônia, baseando-se nas experiências cotidianas das pessoas que se vinculam com essa questão, a partir de variadas posições das pessoas nesse jogo de relações: como chegaram lá, como vivem, de que maneira participam da vida comunitária, como percebem a problemática ambiental localmente, quais as relações com os poderes públicos estabelecidos, entre outros.

Os discursos sobre a questão socioambiental misturam-se num complexo de nomeações, causas e efeitos, invocados a partir de temáticas que buscam dar uma certa ordem às dialogias estabelecidas entre a pesquisadora e os sujeitos da pesquisa. Entretanto, como se pode observar a seguir, tais invocações fazem parte indissociável de uma argumentação maior, que extrapola os temas mais comuns sobre o ambiente direcionando-se rumo aos impactos causados pelo sistema econômico e pelo modelo de sociedade da qual fazem parte.

Em decorrência da metodologia desenvolvida, não se adotou um critério de representatividade numérica dos sujeitos; também não se definiu uma amostra das pessoas entrevistadas em relação ao total da população da região. O critério de representatividade foi com relação ao sexo da população entrevistada. Tal critério foi priorizado com o objetivo de estabelecer um possível recorte de gênero quanto às informações obtidas. Nesse sentido, foram escolhidas, aleatoriamente, quinze pessoas do sexo masculino e quinze pessoas do sexo feminino. $O$ objetivo principal foi captar o "discurso" da população que vive o cotidiano da Cratera e, a partir das falas, captar as representações, sentidos e significados sobre ambiente local.

A consulta do material coletado para proceder à elaboração da análise temática teve início com a transcrição das fitas e leitura de cada um dos depoimentos, extraindo-se destes as questões e problemas referidos pelas informantes, 
consolidados nos seguintes temas: ambiente; principais problemas percebidos na Cratera; responsabilidades e propostas de soluções para os problemas referidos.

A seguir, apresentam-se os resultados obtidos a partir da triangulação entre os diversos instrumentos da pesquisa: entrevistas, grupos focais, conversas no cotidiano, observação e consulta de materiais impressos.

\subsection{Resultados das entrevistas:}

\subsubsection{Perfil do grupo de entrevistados e entrevistadas}

Foram entrevistadas trinta pessoas da população que vive na "Cratera da Colônia" sendo 15 homens e 15 mulheres. Em termos de faixa etária, a maioria das pessoas entrevistadas situa-se entre 30 e 50 anos.

No tocante à escolaridade, no grupo de mulheres o nível de escolaridade apresentou-se mais elevado que no grupo masculino, o que vai ao encontro de tendências mais gerais da sociedade contemporânea.

As observações e os dados coletados indicam um nível sócio-econômico mais elevado no grupo dos homens. Quanto à remuneração percebida, a maioria dos entrevistados percebia entre dois a quatro salários mínimos por mês, enquanto que no grupo de entrevistadas a maioria se referiu ao número de um a dois salários mínimos percebidos.

As profissões delimitam campos de trabalho diferentes, segundo os grupos de mulheres e dos homens. Dentre as mulheres encontram-se empregadas domésticas, agentes comunitárias de saúde e donas de casa. $\mathrm{Na}$ população de homens as profissões mais referidas foram as de pedreiro, cozinheiro e ajudante de serviços gerais. Uma grande parte dos entrevistados mencionou estar desempregada.

Com relação ao vínculo com alguma associação ou movimento social, uma parte declarou estar filiada à ACHAVE; e uma parte das mulheres está associada à AMUVE Associação de Mulheres de Vargem Grande. 
Com relação à origem dos entrevistados e entrevistadas, a grande maioria apresenta como local de nascimento cidades do nordeste brasileiro.

A seguir aborda-se o panorama estabelecido com base em emaranhado de representações, repertórios, discursos e significados apreendidos, organizados a partir de eixos analíticos:

\subsection{Relatos sobre a história de ocupação da "Cratera da Colônia": Do movimento inicial para a compra da gleba até o início da ocupação}

Segundo os entrevistados/as, o início da ocupação da área começou com a criação de uma entidade denominada UNIFAG- União das Favelas da Micro Região do Grajaú, em fevereiro de 1986, por iniciativa da Sra. Maria Henrique Sipriana. Dentre os propósitos de seu estatuto inicial, destacava-se: "unificar e coordenar a ação das favelas, para levá-las a decisões conjuntas com o Conselho Regional e Municipal das Favelas de São Paulo". Além disso, a entidade deveria promover ações assistenciais e cursos de formação e capacitação para liderança.

Entre os objetivos da UNIFAG estava a conquista da casa própria, por meio da organização da "luta das famílias que estão em extrema necessidade, pedindo socorro, tanto favelados como inquilinos, e que quiserem, devendo ser pessoas casadas, com filhos, mães sem marido, mães solteiras, pessoas idosas, desempregadas, e também rapazes solteiros de maior idade". Algumas regras, porém, foram estipuladas para a aquisição da área: que cada interessado pudesse adquirir somente um lote e que não possuísse nenhum outro imóvel; nenhum interessado poderia ganhar mais do que dois salários mínimos por mês.

Em 1988 a UNIFAG anunciou o interesse em comprar uma gleba e abriu as inscrições para pessoas interessadas em adquirir um lote. No entanto, aqueles critérios definidos no estatuto não foram seguidos. No ato da inscrição, bastava preencher uma ficha de inscrição e pagar duas prestações referentes à aquisição, para se tornar um proprietário. 
Depois de muita procura foi identificada, como uma área possível de ser adquirida a Fazenda de João Rimsa, na região de Parelheiros. Segundo os depoentes, naquela época desconheciam o fato que a mesma continha a área da "Cratera da Colônia".

De acordo com os entrevistados, formavam-se "romarias" dos filiados da UNIFAG para conhecerem a área identificada. Muitas reuniões foram organizadas, nas quais discutiam questões referentes ao fato de a área estar dentro de uma região sobre a qual incidia a legislação estadual de proteção aos mananciais (LPM) e as limitações impostas à construção neste tipo de propriedade.

De acordo com a legislação da época, a maior parte do loteamento tinha suas terras classificadas como de primeira categoria (ocorrência de cursos d'água e matas de interesse metropolitano), e de segunda categoria, o que impunha severas restrições ao assentamento humano.

Os filiados da UNIFAG optaram, em assembléia, pela aquisição da área, cientes das restrições legais à gleba adquirida e cientes, também, das dificuldades decorrentes que enfrentariam. Imediatamente procedeu-se a execução de uma proposta ao proprietário das terras. Este, de antemão, recusou a proposta ,alegando ter recebido outra oferta de um grupo japonês, que tinha a intenção de montar ali um campo de golfe. Foi efetuada uma contraproposta em que a UNIFAG ofereceu o dobro do valor inicial, a qual foi aceita pelo proprietário.

Assim, em março de 1989, concretizou-se a aquisição, pela UNIFAG, da gleba de $2.932 .000 \mathrm{~m}^{2}$, onde está localizada a "Cratera da Colônia". Os recursos para aquisição da gleba advieram dos associados da UNIFAG, que pagaram pelo direito de possuir um lote naquele local, sendo que a entidade lhes prometeu o loteamento na área, elaborando uma planta e inscrevendo-os para um futuro sorteio dos lotes. De acordo com um dos entrevistados que fazia parte do grupo inicial da UNIFAG, houve um empréstimo por parte de importante figura política do Estado de São Paulo, de uma parte em dinheiro para poder completar a quantia necessária.

A partir da aquisição do lote, cada proprietário se comprometia com o pagamento dos valores restantes referentes à compra do lote, além das taxas de 
condominio. Os compradores também se comprometiam em participar das assembléias organizadas pela UNIFAG.

Quando a UNIFAG concretizou a transação de compra da gleba, o governo do Estado de São Paulo já havia construído, no ano de 1986, um Presídio Estadual, no local.

Conforme relato de um membro da ACHAVE, houve por parte dos moradores das áreas vizinhas inúmeras manifestações de repúdio à compra efetuada pela UNIFAG. Essa reação acabou sendo divulgada pela imprensa, trazendo inúmeros contratempos para os proprietários dos lotes.

"Falava-se na ocasião, pela imprensa, que Vargem Grande iria se transformar na maior favela da América Latina. O grande problema é que, quando a gente comprou o lote, tivemos que usar o nome da UNIFAG - e como o próprio nome dizia - União das Favelas do Grajaú, isso causou muita revolta e descontentamento por parte dos moradores mais antigos aqui da região. Aos poucos a gente foi mostrando para essas pessoas que nós não éramos bandidos, que nós não invadimos a área. Nós compramos a área para morar!"

\subsection{Do início da ocupação à autoconstrução dos equipamentos básicos}

O papel exercido pela UNIFAG foi preponderante para a concretização da ocupação da área, o que se evidencia por meio dos comunicados transcritos a seguir.

"Foi assim que compramos a terra, fizemos a medição topográfica, abrimos as ruas, realizamos as obras de drenagem, terraplanagem, assentamentos de tubos, enfim, produzimos os lotes. Porém não basta garantir o acesso aos lotes. Necessitamos de melhoramentos. Mas falta instalar a rede de água e de esgoto e, para concluir a urbanização, precisamos do cascalho, guias, sarjetas, canalização da água de chuva e por fim o asfalto." 
“(...) Lamentamos informar que temos um grupo de associados que se mancam, ficam na moita, não contribuem. Uma vez garantido o acesso ao lote, resolveram não cooperar mais com os companheiros ou não acham mais necessária a cooperação (....)"

“(...) esses associados estão se tornando parasitas aqui dentro, vivendo às custas dos que contribuem. Outros são tão relaxados, parecendo certos moradores típicos de favelas. Lá ainda se justifica acomodar-se à sujeira, aos esgotos, aos atoleiros. Mas aqui, com um pouco de boa vontade é possivel evitar tudo isso. Parece que até perderam a vergonha, pouco lhes importando sujar as ruas. Fechados em seu individualismo, pensam assim: O lote meu e a rua é de ninguém! Quer dizer, nada aprenderam com esse trabalho em conjunto nesses 4 últimos anos(....)"

“(...) Mas não é por isso que vamos fracassar, por causa de uma minoria que se omite. Foi assim desde o começo, a maioria consciente segura as pontas, vai para a luta e ganha a parada, levando sempre a melhor.Parabéns a grande maioria dos sócios esforçados! (....) ${ }^{* / 4}$

E assim, em meio a uma grande turbulência, começou a ocupação da área com a implantação de um loteamento sem aprovação, e com uma previsão de lotes com metragem que contrariava a lei: os lotes eram demarcados em $250 \mathrm{~m}^{2}$ enquanto que a LPM permitia lotes de, no mínimo $500 \mathrm{~m}^{2}$ para aquela região. Em pesquisa realizada por VICTORINO (1996) foi observado um grande número de lotes parcelados em lotes de $125 \mathrm{~m}^{2}$ acentuando ainda mais o comprometimento ambiental.

Contrariando as legislações vigentes, segundo as quais, em áreas de primeira e segunda categoria, são proibidos os desmatamentos, a remoção da cobertura vegetal e o movimento de terra, a UNIFAG iniciou o processo de derrubada da

\footnotetext{
${ }^{14}$ Boletim Informativo da Associação Comunitária Habitacional: Janeiro de 1994.
} 
cobertura vegetal, tendo como conseqüências secundárias o assoreamento e o aterro dos cursos d'água, causados pelo movimento de terras realizado para abertura de ruas.

Como ocupavam uma Área de Preservação aos Mananciais e o loteamento era considerado clandestino, os adquirentes não podiam receber nenhum tipo de infraestrutura, por parte da Prefeitura Municipal de São Paulo, tais como: serviço de coleta de lixo, energia elétrica, linhas de ônibus, abastecimento de água, coleta de esgotos, calçamento, construção de escolas, entre outros. A única solução seria a obtenção desses equipamentos por vias alternativas.

"No inicio foi muito dificil para a gente começar o desmatamento da área, para fazer o arruamento, para conseguir a água encanada pois sempre tinha a policia florestal por perto, mas as coisas, aos poucos foram se arranjando, seja por meio de trocas de favores com os policiais, com políticos, e até mesmo por meio de distribuição de propinas".

“A gente não tinha água e nem luz, no inicio nós construímos somente um quarto, uma sala, cozinha e banheiro, tudo bem pequenininho. O meu vizinho que também é meu compadre é quem me emprestava a água de seu poço. Todos os dias a gente enchia todas as vasilhas da casa. A luz a gente puxava da casa dele também! Quando a gente vê como está Vargem Grande hoje a gente não tem idéia como era isso quando nós viemos para cá. Hoje está uma beleza! Mas tudo o que conseguimos foi as nossas custas. Primeiro foi a organização para conseguir a água tratada; depois foi a luta para a construção da escola, do posto policial e do asfalto ecológico, e assim a gente continua lutando para outras melhorias aqui para o bairro!" 
Assim sendo, tudo que os moradores conseguiram, em termos de equipamentos físicos e sociais, foi obtido por meio de troca de favores com policiais locais, com políticos; desde vereadores até a figura do Governador do Estado foram citados como parceiros nessa ocupação, numa etapa já mais adiantada da ocupação da mesma. "As telhas para a cobertura da escola que nós construímos foram doadas pelo Governador".

De acordo com os moradores mais antigos da área, um dos problemas graves que enfrentavam era a falta de iluminação. Às 18 horas já não havia luz natural no Condominio Vargem Grande e a região, sob forte cerração que encobria toda a Cratera, ficava às escuras.

“Com o passar do tempo nós passamos a pegar a energia do poste que passa lá na estrada. Você nem imagina como era isso, era um emaranhado que parecia macarrão, era uma montoeira de fio, mas quando a energia chegava em nossas casas era muito fraquinha, mas era o possivel naquela altura do campeonato. Muitas vezes vinham alguns engraçadinhos e cortavam os fios, ai era a maior trabalheira para refazer a fiação".

Rede de abastecimento de água também não havia. Aqueles que não tinham poço freático para conseguir água para as necessidades básicas da família tinham que caminhar até alguma mina existente na região. Munidos de garrafas plásticas, galões e baldes, uma multidão de homens, mulheres e crianças disputava a sua vez na fila para conseguir o tão precioso líquido. Quando a noite caia era necessário iluminar as minas com velas.

"No começo a gente não tinha nada de benfeitorias aqui no Vargem Grande. (...) a gente é que furava os poços, a luz a gente ia buscar lá na estrada. Era fraquinha que só vendo! Quem não furava poço tinha que caminhar até as minas de água. Era uma situação muito dificil pois tinha filas imensas, principalmente no final da tarde! Foi ai que começamos a luta para trazer água 
tratada aqui para o bairro. No inicio, a SABESP colocou umas caixas d'água em vários lugares do bairro (...)”.

“A situação era muito dificil, muitas vezes precisávamos chamar a policia, de tantas brigas que aconteciam pelo fato de algumas pessoas furarem a fila".

Quanto ao transporte urbano, o único recurso com o qual os moradores contavam para transportá-los até o local de trabalho era um velho ônibus da antiga CMTC, usado, normalmente, para transporte dos pescadores que iam até a barragem. Para conseguir pegar o ônibus, que só passava na estrada que ia para a Colônia, muitos moradores tinham que caminhar em torno de três quilômetros, até chegar ao ponto, muitas vezes em situação bastante difícil pela falta de calçamento das ruas.

"Para você ter uma idéia, o ônibus tinha alguns buracos no chão que dava para passar uma pessoa. Como era um ônibus que transportava os pescadores que iam pescar na Barragem, tinha uma catinga de peixe insuportável!".

“O ônibus só passava lá na estrada que vai pro Colônia, então a gente tinha que caminhar até lá se quisesse sair daqui. Quando chovia era um problema, porque isso aqui formava um brejo só! Eu e minha mulher tínhamos uma técnica: a gente ia com um calçado até o ponto; quando chegava lá a gente guardava o sapato cheio de barro num buraco de tatu; e quando a gente voltava, no fim da tarde, a gente trocava novamente, foi indo assim até o dia em que quando a gente voltou no final da tarde, e fomos até o buraco do tatu, e cadê os sapatos? Tinham descoberto o nosso esconderijo!". 
De acordo com diversos depoimentos, a então presidente da Associação firmava diversos acordos com policiais civis em troca de segurança pessoal e também para a segurança do Condomínio. A contrapartida era a distribuição de lotes na área para esses policiais.

Em alguns casos os policiais eram contratados pela Associação, em seus horários de folga, mediante um salário para fazer a segurança do local. Cabe destacar que até hoje a ACHAVE vem sofrendo as conseqüências no que se refere a essas contratações. dois de quatro policiais contratados, na época, reivindicaram na justiça os seus direitos trabalhistas, tendo recebido ganho de causa. Como até os dias atuais a causa não foi liquidada, a ACHAVE encontra-se com os seus bens e contas bancárias bloqueados.

Aos poucos, os moradores foram se articulando em torno da Associação Comunitária, para conseguir as benfeitorias básicas necessárias para a região. Inicialmente, por meio de acordos políticos foram conseguidos, junto à SABESP, os tanques de água. Os demais serviços, tais como: coleta de lixo, energia elétrica e linha de ônibus, foram conseguidos por meio da distribuição de propinas, segundo relatos de diversos associados.

Conforme Boletim Informativo da Associação Comunitária Habitacional emitido em janeiro de 1994, após assembléia geral ocorrida em 12 de dezembro de 1993, os associados decidiram cascalhar as ruas do loteamento; na época, foi cobrado um metro cúbico de cada sócio.

"Após encaminharmos oficio ao Dr. Reynaldo de Barros, secretários das vias públicas e ao administrador regional de Capela do Socorro, da época, solicitando cascalho nas ruas e tendo eles respondido que nada podiam fazer, não tivemos outra saída senão contarmos conosco mesmos, como aliás foi desde o começo, seguindo sempre o lema: um por todos e todos por um. Conquistamos o grande beneficio da energia elétrica e da coleta de lixo, agora vamos conseguir o calçamento!". 
O calçamento, existente em algumas ruas da Cratera, foi pavimentado pelos próprios associados, utilizando "bloquetes ecológicos" que eram confeccionados na própria ACHAVE, que contratava pessoas da comunidade mediante o pagamento de um salário, uma cesta básica e de alimentação. Aquelas pessoas que deviam taxas de condomínio para a ACHAVE tinham a possibilidade de quitar as suas dívidas em troca do trabalho prestado nas construções em mutirão.

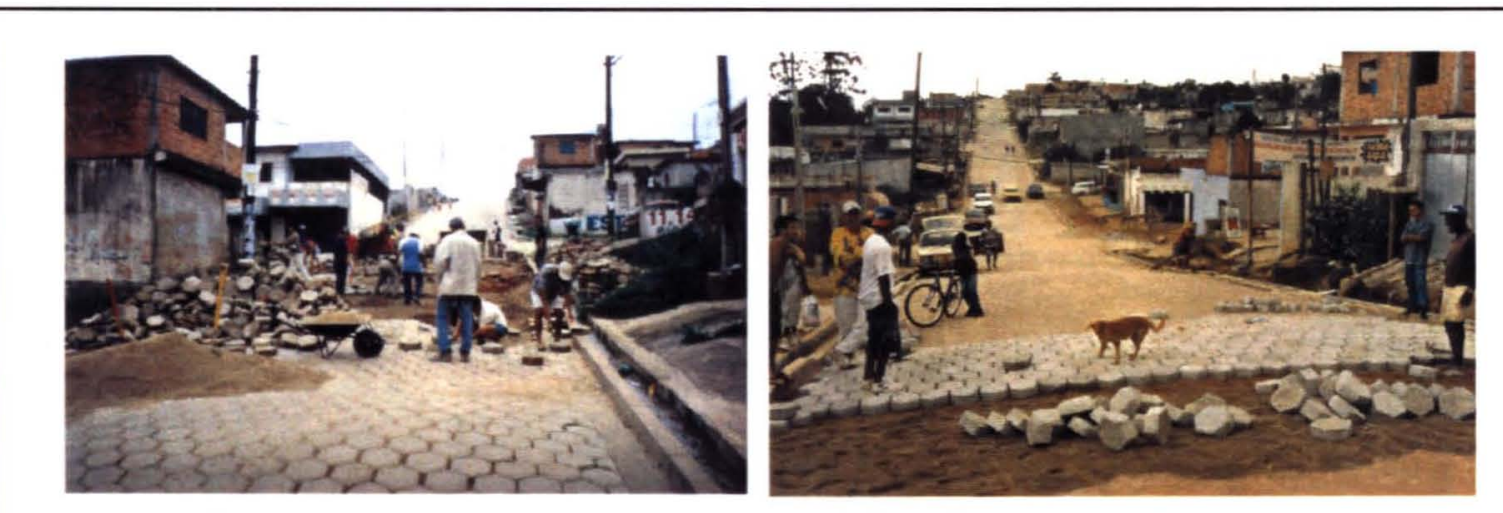

Figura 19 - Construção do calçamento ecológico pelos moradores do Condomínio Vargem Grande.

Em 1995 tornou-se imperativo a construção de uma escola para os filhos dos proprietários de casas no Condomínio. Uma vez que não podiam contar com as benfeitorias por parte da Prefeitura, os diretores da Associação Comunitária resolveram, eles próprios, construir a escola em mutirão. Cada morador ajudava como podia: em serviços prestados ou em materiais de construção. 


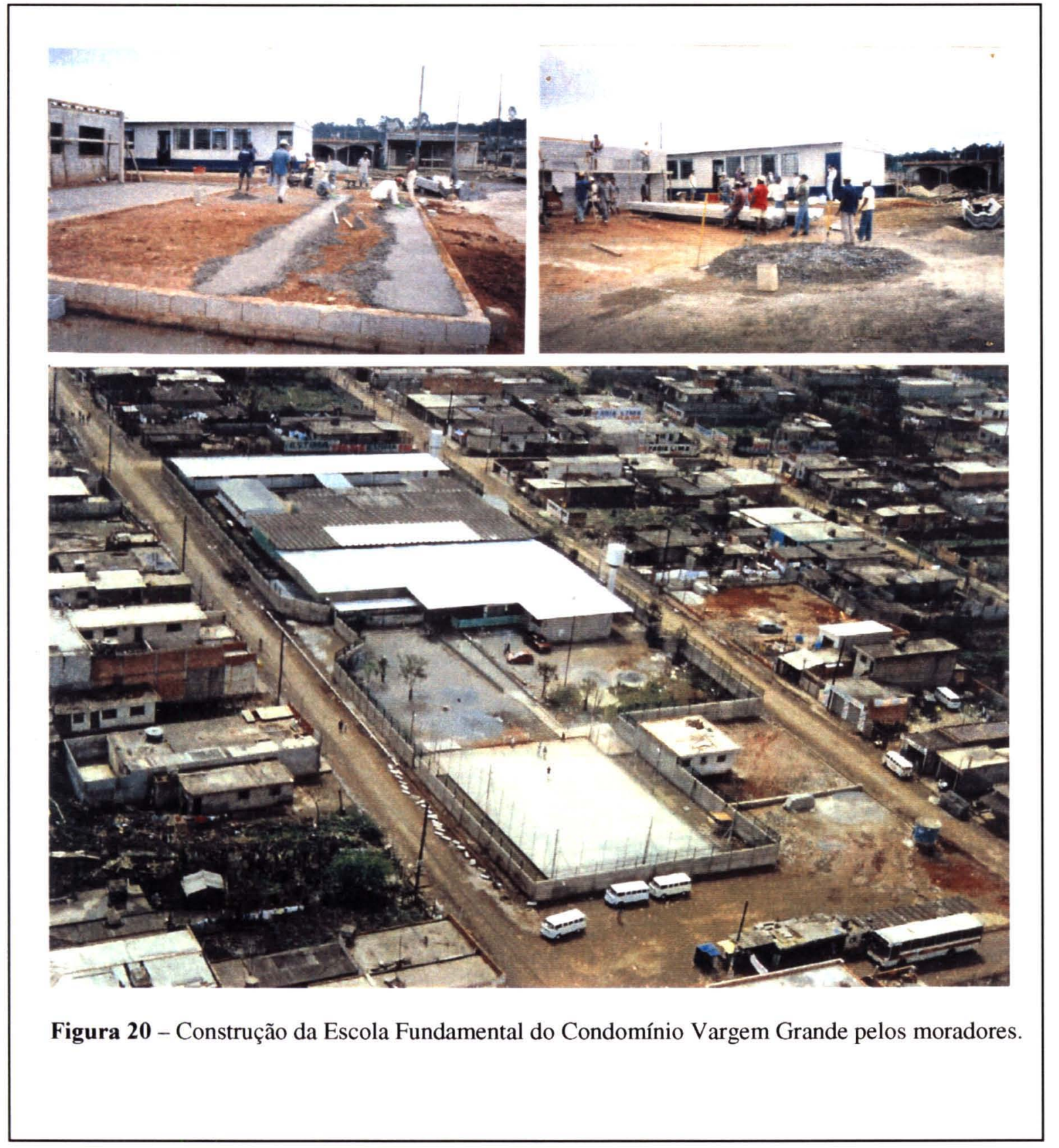

As técnicas de usos e apropriação dos recursos da natureza desenvolvidos pelos homens ao longo de suas vidas, a fim de preencher suas necessidades vitais, revelam-se como práticas sociais cotidianas onde o saber é, quase que imediatamente, o fazer. "E este saber fazer não encontra expressão apenas no nível dos indivíduos, das famílias, das coletividades. A vida comunitária implica, freqüentemente, o aproveitamento dos talentos das pessoas e recursos disponiveis que a integram". (IANNI 1999). Em Vargem Grande, o aproveitamento dos talentos 
das pessoas da comunidade e dos recursos disponíveis foi uma tônica que permeou o discurso de homens e de mulheres aue, por meio de seus conhecimentos, foram produzindo socialmente o ambiente da Cratera da Colônia.

"Algum tempo que a gente estava aqui a gente foi sentindo a falta que fazia uma escola para as nossas crianças. Depois de muito pelejar junto da Prefeitura, sem nada conseguir, foi então que surgiu a idéia de construir nós mesmos a escola. No início foi uma batalha dentro da própria Associação, pois a presidente não concordava com a idéia da escola, mas depois de muita briga nós conseguimos aprovar na ACHAVE a construção da escola em sistema de mutirão. Acho que tinha bem umas quarenta pessoas envolvidas na construção".

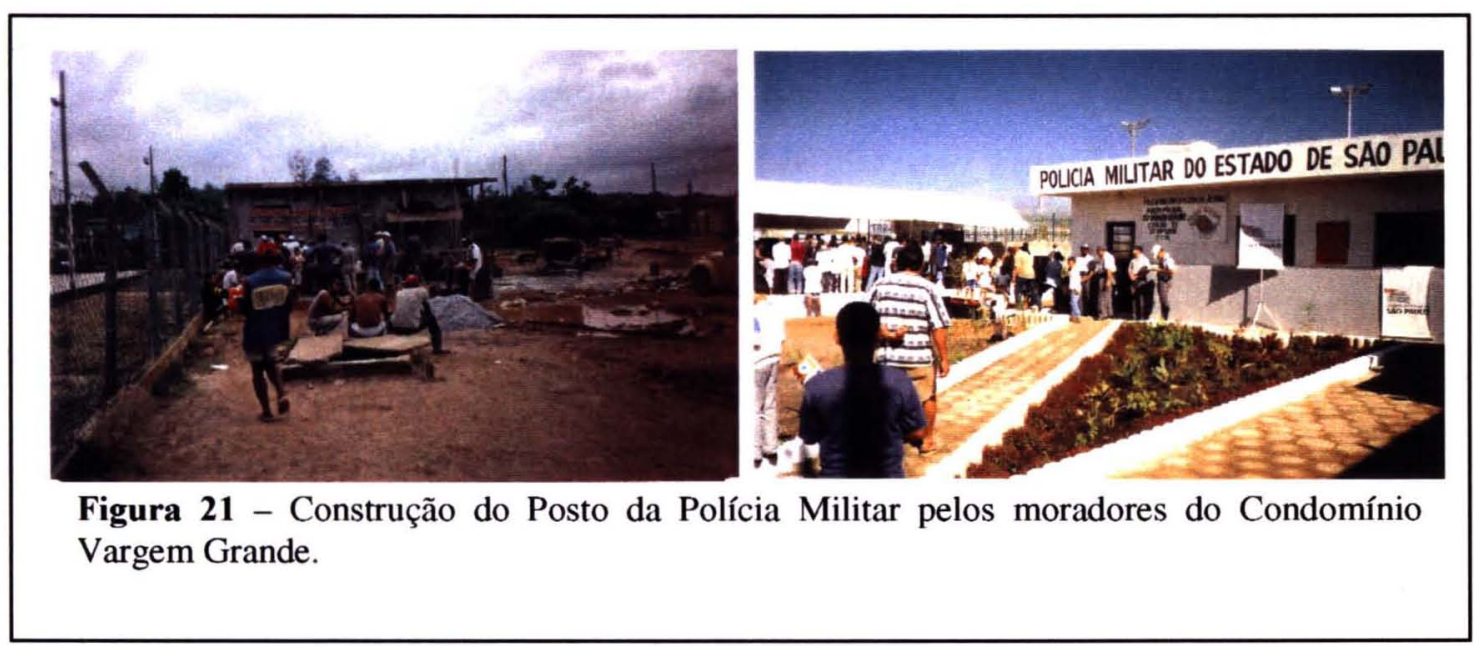

Um grupo de mulheres organizava o mutirão para recolher as doações de materiais e de alimentação dentro do condomínio. Outro grupo de mulheres se incumbia da preparação da alimentação para os trabalhadores. 
"Havia um grande envolvimento da comunidade nas lutas travadas pela Associação em busca de melhorias para a Cratera da Colonia. Primeiro foi a luta pela água tratada, depois veio a luta pela construção da escola, depois veio o posto policial, o posto de saúde, o calçamento ecológico. Tudo o que nós temos hoje aqui foi em função do nivel de organização que a gente tinha!.".

\subsection{Conhecimento prévio sobre a área escolhida}

Indagados sobre a consciência dos compradores a respeito das restrições ambientais que incidiam sobre a gleba adquirida, os entrevistados foram unânimes em responder que conheciam a situação antes de comprar o lote.

"A Sipriana convocou diversas reuniões para nos explicar sobre a área a ser adquirida. Ela deixou muito claro que se tratava de uma área reservada para os mananciais. Embora para muitos não tenha ficado muito claro o que significava o fato de estar dentro da esfera da LPM, houve uma assembléia onde a maioria se mostrou esclarecida sobre a área e o que isto significava perante a lei. Havia uma sensação que aquela era a nossa única oportunidade de ter a nossa casa própria, as pessoas estavam cansadas de serem despejadas dos locais onde moravam, de ficarem na rua sem lugar para morar, dai optamos em comprar a gleba".

Esta posição vem ao encontro do depoimento da Sra. Maria Sipriana ao Poder Judiciário de São Paulo, em 5/10/1989, destacado no trabalho de VICTORINO (1996).

“Na ocasião \{antes da compra\} comentamos, inclusive, que era uma área reservada para mananciais e, por isso, legalmente protegida e nela não era possível loteamentos e construções. Fizemos várias reuniões para discutirmos o assunto (sic) a residencia e moradia e, por fim, ficou decidido que a entidade 
compraria uma área para dividi-la posteriormente e entregá-la aos associados (...) Nós sabiamos da restrição da construção no local, por se tratar de uma área de proteção de mananciais. Eu esclareci meus associados a respeito das proibições e até levei advogado e arquiteto para explicar a eles do que se tratava. Cheguei até a solicitar manifestação da Assembléia, de todos os presentes, para que erguessem as mãos para eu ficar sabendo se haviam entendido que se tratava de uma área de proteção de mananciais. Eu percebi que embora muitos tivessem dúvida, a maioria, entretanto, havia entendido do que se tratava. Porém, eles próprios disseram que já estavam cansados de ficarem desprotegidos, sem lugar para morar e despejados dos locais onde conseguiam ficar. Dai então que se decidiu pela compra da área".

Os depoimentos anteriormente transcritos revelam que, tanto os dirigentes do movimento como os compradores dos lotes tinham conhecimento de que se tratava de uma gleba protegida pela LPM, mas mesmo assim, cientes das restrições ambientais, optaram por comprá-la, realizando, dessa maneira, o sonho de ter uma casa própria, de ter um teto para morar.

Um outro fator preponderante para a aquisição da gleba foi o seu valor, bastante depreciado em relação às áreas fora do perímetro dos mananciais.

“Na época em que adquirimos a gleba, era inviável para a gente comprar uma área fora da área de mananciais, pois o preço era duas a três vezes mais caros do que na região dos mananciais. Esta gleba na área da Colonia era o que podiamos adquirir com as nossas posses".

Diversas pesquisas vêm apontando que é justamente nas áreas rejeitadas pelo mercado imobiliário privado e nas públicas, situadas em regiões desvalorizadas que a 
população trabalhadora de baixo poder aquisitivo vai se instalar: beiras de córregos, encostas de morros, terrenos sujeitos a enchentes ou ainda, em áreas de proteção ambiental, onde a vigência de legislação de proteção e a ausência de fiscalização definem a desvalorização (MARICATO 2001).

"Na época eu não estava nem ai para esse negócio de reservas, o que eu queria era um lugar para morar. Acho que esse negócio das pessoas vir morar em áreas de mananciais é por pura necessidade, porque nessas áreas é onde a gente pode comprar, porque é mais barato!".

Quanto ao conhecimento da área se constituir numa cratera causada por impacto de um astro celeste, a maioria dos entrevistados, especialmente aqueles que não participam das atividades da ACHAVE, enfatizou que nem imaginavam que isto poderia ter acontecido, e também que esse fato não é uma preocupação.

"Mais importante que essa história do meteoro que despencou do céu há não sei quantos milhões de anos atrás, é a falta de iluminação, o problema da falta de esgotos, a falta do que fazer desses jovens do bairro".

“Eu vejo as pessoas falando sobre esse negócio que aqui é um lugar onde caiu um meteoro, mas eu não sei bem o que isso significa e também não importa muito se é verdade ou não. $O$ que importa são os problemas que nos atingem no dia-a-dia e que precisam ser resolvidos. Precisamos de esgoto, precisamos de lazer para os nossos jovens que cada dia mais vem se envolvendo com a bandidagem!" 
Já para os entrevistados militantes na Associação Comunitária, o fato da área da qual são proprietários abrigar uma estrutura geológica de tal porte faz com que haja uma valorização singular da área, uma vez que esta pode se transformar, futuramente, em parque de visitação turística, o que poderia render benefícios para a própria comunidade.

Para o diretor do Centro de Detenção Provisória de Parelheiros, onde 1.200 pessoas cumprem pena, essa história da queda de um meteoro no lugar pode ter até um efeito positivo sobre a segurança pública. "Na dá para fazer túnel, se cavarem meio metro, os presos acabam afogados dentro da água".

\subsection{Início dos conflitos na gestão da Associação: Da UNIFAG a ACHAVE}

A presidente da entidade UNIFAG que, desde o início do processo, mostrara-se bastante hábil para agregar os filiados e adquirir a área, passou, em determinado momento, de acordo com os entrevistados, a assumir uma postura ditatorial em relação aos filiados da UNIFAG, a não prestar mais contas de seus atos aos diretores da entidade. De acordo com vários depoimentos, a presidente começou a determinar algumas regras à revelia dos filiados, tais como: colocou uma cancela na entrada do condomínio, controlando a entrada e saída dos moradores; obrigava os moradores a comprarem gás de um depósito de sua propriedade; e outras atitudes que contrariavam os diretores e também os filiados da associação.

Instaurou-se, dessa maneira, um grande conflito no seio da UNIFAG: de um lado, a presidente, e de outro, os diretores e grande parte dos filiados da entidade, descontentes. Outra razão para as desavenças instauradas no seio da entidade era com relação aos propósitos de construção da escola.

Os membros da então diretoria da UNIFAG tinham como objetivo a construção de uma escola que fosse gratuita para todos os filhos dos condôminos. A presidente da UNIFAG concordava com a construção da escola, desde que ela fosse paga. Nesse clima aconteceram então as eleições para a composição de uma nova diretoria. 
Após uma série de incidentes pessoais foi estabelecido um consenso: o presidente eleito aceitou os vários objetivos dos opositores, membros da antiga diretoria, entre eles, a construção da escola, que se iniciou e foi concluída em sistema de mutirão.

\subsection{O processo de autoconstrução da moradia}

“A gente se encontrava nos fins de semana para limpar a área, a gente ia derrubando o mato, as árvores e ia preparando o lote para construir. Cada proprietário preparava o seu lote. Para ajudar, a gente trazia a familia toda e os amigos. Depois que tava tudo limpinho ai então a gente comprava o material e começava a construir, sem nenhuma orientação técnica. A gente ia perguntando para outros que sabiam mais. No começo, a gente só construia o básico mesmo para morar - quarto, cozinha $e$ banheiro, e deixava o resto para construir conforme as coisas fossem melhorando. Era uma grande festa. Vinha todo mundo: mulher, crianças, amigos. Pra comer, a gente assava uma carninha! A maioria das casas aqui do Vargem Grande foi construida assim. Só tinha uma regra, definida pela UNIFAG: barraco de madeira só podia ser provisório, por 90 dias, depois desse prazo só casa de alvenaria! Acho que isto que não permitiu que isso aqui virassse uma favelona!". 


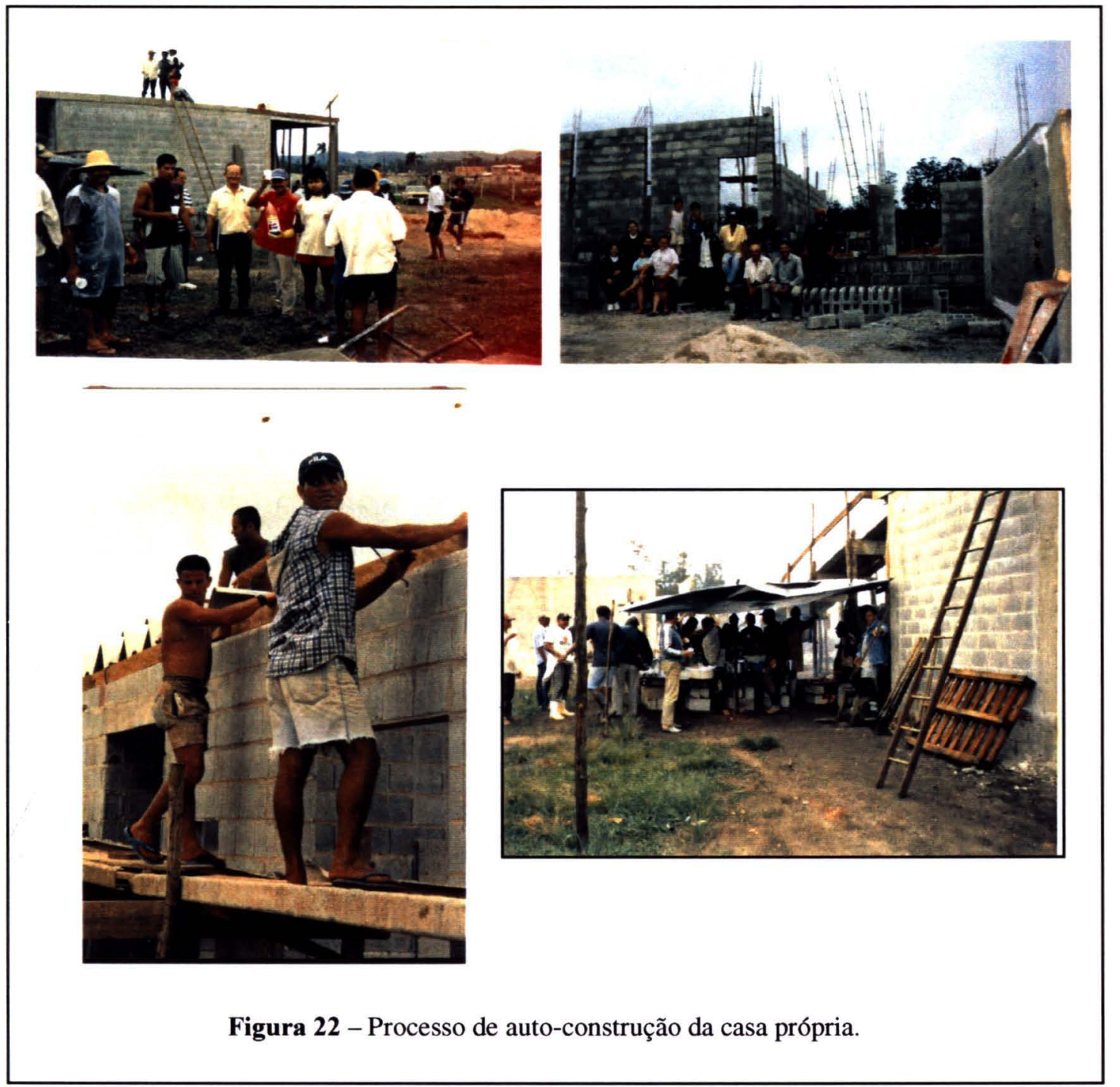

$\mathrm{Na}$ época em que foi colhido o depoimento acima, em meados de 2003, o proprietário continuava a construir a sua residência. $\mathrm{O}$ trabalho vinha sendo realizado aos domingos, somente com a colaboração de um ajudante. Nos primeiros anos da ocupação, ele construiu toda à parte de baixo (dois quartos, sala, cozinha e, banheiro) que, na ocasião, encontrava-se alugada. Em 2004, estava terminando a construção da parte de cima. Mais dois quartos, dois banheiros, duas salas, cozinha e área de serviço, tudo muito amplo e muito simples. Não havia acabamento externo, só havia o reboque feito de massa. Tal como ocorria em outras construções, algum aspecto daquela construção requeria algum ajuste - no caso, os degraus da escada - que, 
segundo o proprietário, precisava ser reconstruído pois estava com problemas estruturais, visível aos mais leigos.

“... a gente vai fazendo de orelhada, vendo os outros fazerem, na maioria das vezes a gente acerta, mas as vezes a gente também erra né, ai a gente conserta porque errar também faz parte da aprendizagem".

A maioria das casas construídas no Condomínio utilizou-se dessa forma de autoconstrução. Inicialmente, grande parte dos proprietários construía uma casa de três cômodos, quarto, cozinha e banheiro para, posteriormente, terminar a construção, na medida que algum dinheiro fosse sobrando. Dessa forma, o que era, imaginado como um condomínio planejado, com ruas arborizadas e estruturadas, transformou-se num bairro típico da periferia de São Paulo. O tom que predomina na Cratera é o cinza do cimento e o ocre dos blocos das casas de baixo e médio padrão, semiacabadas, ou ainda em construção.

Na cidade de São Paulo, desde o início do século XX, já existiam relatos de trabalhadores que construíam, eles próprios, as suas moradias, especialmente na zona rural, porém, até a década de 1920, esta prática não era significativa como alternativa factível de moradia popular para a classe trabalhadora. (ROLNIK 1996).

BONDUKI (1998), que desenvolveu extensa pesquisa sobre o tema, denominou esse modo de fazer como auto-empreendimento da moradia popular, que se baseava no trinômio loteamento periférico, casa própria e autoconstrução. Para este autor, em conseqüência da crise habitacional, da desestruturação do mercado rentista e da incapacidade do Estado em financiar ou promover a produção da moradia em larga escala, consolidou-se, a partir da década de 1940, no Brasil e,em especial, na cidade de São Paulo, essa forma de construção de moradia dos setores populares, à margem do mercado formal e do Estado.

A autoconstrução, possibilitada pela simplicidade dos processos produtivos é, geralmente, resultado de uma combinação de fatores sociais, econômicos e culturais: 
significa o emprego do tempo livre do trabalhador na produção de sua própria moradia, mercadoria com alto valor agregado dentro do sistema capitalista e um bem essencial para a reprodução social dos indivíduos pobres e ricos.

Diversos nomes eram usados para identificar esse tipo de construção: casas domingueiras, casas próprias autoconstruídas, casas de periferia, casas de mutirão, dentre outros. A despeito do nome usado, o que caracterizava esse tipo de construção era o fato da edificação ser gerenciada pelo próprio morador.

Esse sistema de autoconstrução da casa própria proliferou-se vertiginosamente, após a década de 1940, na esteira das transformações urbanas, econômicas, imobiliárias e de reprodução da força de trabalho ocorridas sob a intervenção do Estado.

Segundo BONDUKI (1998) é muito dificil quantificar a expansão desse processo, visto que ele ocorreu às margens das estatísticas oficiais, porém, baseandose na análise da evolução do número de domicílios próprios no período compreendido entre 1940 e 1970, feitos pelo IBGE, os dados revelam o grande incremento da propriedade na cidade de São Paulo: enquanto que, em 1940, somente $25 \%$ dos domicílios eram ocupados por proprietários, no ano de 1970 , este número sobe para $54 \%$.

“O auto-empreendimento na periferia, configurando o território da aventura individual, da propriedade privada, da moralidade cristã e do conservadorismo político - no espaço da casa em construção, do lote bagunçado, da quadra clandestina, da ma semioficializada, do ponto de ônibus sempre cheio, do tempo infinito até o trabalho -, formou a base do que chamo de modo de vida paulistano, tornando-se uma referência cultural estruturadora do cotidiano dos habitantes da cidade. Participar desse processo tornou-se sinal de incorporação à cidade e à cidadania, e também a aspiração máxima de ascensão social acessivel aos trabalhadores de baixa renda". (Bonduki 1998, p.283). 
A condição de vida desenvolvida na Cratera da Colônia parece retratar exatamente o que Bonduki (1998) ressalta no texto acima. A maioria das casas é autoconstruída, semiacabada, os pontos de ônibus estão sempre cheios; quando chove, as ruas se tornam intransitáveis, tudo se transforma num pântano; os esgotos correm a céu aberto; o tempo necessário para chegar ao trabalho é extremamente longo; as crianças vivem doentes. A despeito de todas essas mazelas, os moradores da Cratera da Colônia são extremamente orgulhosos de seu empreendimento. Há um reconhecimento evidente de que esta era a única possibilidade que eles tinham de conseguir a tão sonhada casa própria, uma moradia digna, que por ser tão fundamental para a vivência e à convivência humana todos a desejam. Parece que o fato de possuir uma casa própria os aproxima da condição de cidadãos.

"A gente comprou o lote na confiança. Demos todo o nosso dinheiro para a Sipriana e acreditamos que o negócio iria sair. Era a oportunidade que a gente tinha que ter a nossa casa, de sair do aluguel. Assim como nós, outros fizeram a mesma coisa. Aí ela pegou todo o dinheiro e começou a procurar o terreno. Era um dinheirão que estava na mão dela. Depois de algum tempo de procura por um terreno que fosse compativel com o que a UNIFAG tinha, ela convocou uma reunião para falar sobre essa área da Cratera. De início ficamos meio receosos por se tratar de uma área de manancial, mas depois, quando vimos que seria muito dificil adquirir um terreno adequado em outro lugar, resolvemos comprar esse mesmo. Tinha romaria para ver a área, era uma beleza! Assim que estava tudo certo começamos a preparar a área para construir a nossa casinha. No inicio a gente se reunia aos fins de semana para fazer o desmatamento, essa foi a primeira etapa para a abertura das ruas. Foi uma fase bastante dificil porque isso aqui era um matão, mas também tinha um grande orgulho pelo fato da gente estar preparando a construção da nossa casa própria". 
Nem a possibilidade de serem enquadrados pelas leis vigentes na época, por desmatamento de uma área protegida, intimidava esses desbravadores, tão obstinados na construção da casa própria. Logo que começou o desmatamento para a abertura das ruas, segundo os relatos dos moradores, foram aparecendo os fiscais florestais responsáveis pela área.

E assim a questão ambiental começou a se prenunciar para essa população.

\subsection{Relatos sobre aproximação com a questão ambiental}

"Junte-se a nós: vamos preservar o meio ambiente. ACHAVE é nossa entidade!

Cuidado com o local de moradia e com o meio ambiente - Preserve o quanto possivel as árvores do seu lote e plante árvores frutiferas e ornamentais. Não ponha o trator para destruir tudo, jogando na rua madeiras, raizes e tocos. Limpe a rua diante do seu lote, cortando as madeiras e queimando-as. A Associação completará o serviço removendo o que sobrar. Cuide das áreas verdes que foram reservadas para o lazer de sua familia. Transforme-as em pequenos parques. Sabe como é que se conhece o associado consciente? Pelo cuidado que tem com o seu lote, com a sua rua e com as áreas de uso comum. Saiba o que é de todos é também de cada um. Portanto, supere a oposição entre o individual e o coletivo. Comece a educar-se para viver numa sociedade civilizada na qual todos cooperam fraternamente, e todos saem ganhando.",Is

A primeira impressão que se tem, a partir das vozes dos representantes da ACHAVE, é que se trata de grupo de defensores aguerridos do meio ambiente. A defesa da ecologia é a grande bandeira da Associação.

\footnotetext{
${ }^{15}$ Boletim Informativo da Associação Comunitária Habitacional: Janeiro de 1990.
} 
Dos documentos emitidos pela ACHAVE e das falas de seus personagens, $o$ interesse conservacionista é o grande pressuposto que permeia a maioria das ações da entidade.

É possivel constatar que, desde o ano de 1990, boletins eram emitidos pela Associação com referências à questão ambiental; isto parece denotar o início da incorporação dos discursos ambientalistas no cotidiano e nas ações dos dirigentes da ACHAVE.

Pode-se verificar, ainda, em um Boletim Informativo expedido pela Associação, em junho de 1990 que, além de conter explicações aos associados sobre um carnê referente a um rateio de despesas, continha também uma comunicação com dizeres que já faziam referência à necessidade de cuidar do ambiente no Condomínio. Nessa comunicação anunciava-se a questão que iria perdurar até os dias atuais: a preocupação com o ambiente na Cratera da Colônia.

Emerge também da leitura do texto um apelo emocionado à conscientização dos moradores com relação à conservação e a reposição da flora local, além da conscientização sobre os conceitos de "público" e "privado".

A necessidade do associativismo é uma característica que aparece em grande parte dos relatos e documentos.

“A gente já trazia essa noção que só juntando as forças é possivel conseguir alguma coisa. Esse conceito já vinha da nossa participação no movimento de luta por moradia. A própria UNIFAG já era um desses movimentos. A gente aprendeu com a prática que a gente precisa participar, precisa lutar e, principalmente, reunir o maior número possivel de pessoas para conseguir os nossos objetivos. Se você for ver, aqui no Vargem Grande, tudo foi conseguido com a participação dos moradores: foi a água encanada, foi a iluminação, foi a escola, foi o Posto de Saúde, foi o asfalto ecológico". 
Dessa maneira, com a experiência herdada do ativismo nos movimentos de luta por moradias, é que os atores da ACHAVE vão somando esforços com várias entidades e políticos, com o intuito de levarem adiante propostas, reivindicações, denúncias e lutas específicas, tais como o Movimento de Apoio à criação da APA e a participação no movimento de construção da Lei Específica de proteção aos mananciais, na participação no Comitê de Bacias.

\subsection{Participação e ambiente: as diferentes formas de associativismo na Cratera}

Tomando como base uma assertiva aristotélica que considerava o homem como um ser eminentemente social e político, DALLARI (2001) conclui: "todo ser humano é um animal que convive, porque não consegue viver sozinho".

Baseados no pressuposto acima pode-se afirmar que, desde os primórdios da humanidade, homens e mulheres convivem em sociedade e essa convivência se dá em família, em grupos de amigos, no trabalho, na igreja, na escola, nas associações, nos sindicatos, nos partidos políticos, entre outros. Enfim, a participação se dá em variados graus e sob diferentes formas e níveis de qualidade (BORDENAVE 1983).

A partir das reflexões sobre a necessidade do ser humano viver em associação com outros seres humanos, DALLARI (2001), enfatiza a existência do direito da participação que, segundo o seu ponto de vista, deve ser complementado pelo dever da participação, no qual cada ser se beneficia da solidariedade e todos têm o dever da solidariedade. Assim sendo, numa concepção de uma sociedade democrática, para que os interesses de todos sejam considerados, a participação deve ser um pressuposto básico e fundamental.

Entretanto, o estudo mais detalhado sobre os processos de participação revela que, ao longo do tempo, várias e diferentes foram as formas de participação na esfera pública. SCHERER-WARREN (1999) destaca, dentre as diversas formas de participação, o associativismo civil e os movimentos sociais ${ }^{16}$.

\footnotetext{
${ }^{16}$ Associaçōes civis se constituem em formas organizadas de açōes coletivas. ONGs, grupos de cooperaçào, contestatórios, utópicos dentre outros. Já o movimento social é uma categoria mais abrangente que engloba as categorias de associativismo civil e de sujeito social. (SCHERERWARREN, 1999).
} 
$\mathrm{Na}$ Cratera da Colônia, como já foi enfatizado, é em torno da Associação que se congrega grande parte da vida comunitária do Condomínio. A ACHAVE, entidade decorrente da organização UNIFAG tem como objetivo "administrar o condomínio, representar os moradores do Condomínio Habitacional Vargem Grande, promover o envolvimento da comunidade nas discussões sobre o gerenciamento da Área de Proteção Ambiental Capivari - Monos, da qual o Condomínio faz parte e manter o espaço dentro de valores estéticos e ambientais".

Embora se perceba um grande esforço, por parte da diretoria da ACHAVE, em congregar o maior número possível dos moradores em prol das causas ecológicas, seja por meio de atividades coletivas tais como mutirão do lixo, mutirão de limpeza dos córregos e valas, participação nos movimentos em defesa da Billings, ainda há uma grande desconfiança, por parte dos moradores, com relação aos reais interesses da entidade

Alguns moradores referem-se a posturas inadequadas da ACHAVE, em épocas precedentes, especialmente na época da antiga diretoria, quando mesmo a Associação denominava-se UNIFAG.

"Veja bem, a Sipriana foi muito importante para que o Vargem Grande exista até agora, digo mais: se não fosse ela acho que dificilmente esse condominio teria saido. De inicio ela agia da melhor forma possivel, mas, com o passar do tempo, não sei se por influência da família, ou se o poder lhe subiu à cabeça, sei lá! mas as coisas foram se modificando e ela, que de inicio parecia defender o direito da maioria dos associados, depois de algum tempo, passou a assumir posturas contrárias aos interesses da maioria. Isso fez com que fossem geradas muitas desconfianças, por parte dos associados, com relação aos interesses da Associação. Até hoje tem muita gente que não enxerga a Associação com bons olhos baseados nessas posturas da antiga diretoria. Só para você ter uma idéia teve uma época que ela obrigava as pessoas a comprarem gás no armazém que era de 
propriedade dela; teve também o caso da portaria que ela instalou no condominio, todos os moradores tinham que ter uma carteirinha para poder entrar nas suas casas, sem falar do tanto de lotes que ela doava para os conhecidos dela, como policiais que faziam a segurança, irmãos, enfim, vira e mexe aparece alguém aqui procurando o seu lote! Tudo isso contribuiu para que haja muitas desconfianças de muitos associados até hoje com relação a ACHAVE, por mais que hoje a gente tente agir de acordo com os interesses da maioria, tente agir de forma transparente; tente preservar e conservar a ecologia do lugar!".

\subsection{Ações de educação ambiental implementadas na Cratera da Colônia}

Diversas ações de Educação Ambiental dirigidas à população de moradores da Cratera, vêm sendo implementadas por várias organizações. Dentre essas ações destacam-se a ação implementada pela Secretaria do Verde e do Meio Ambiente do Município de São Paulo- SVMA.

A SVMA dispõe de um funcionário técnico, em educação ambiental, e de uma estagiária que atendem não só à Cratera da Colônia, mas a APA CapivariMonos como um todo. Na Cratera da Colônia, esse técnico vem desenvolvendo a organização de uma Cooperativa de Produtos Recicláveis, com atividades no próprio local.

De acordo com palavras do técnico de educação ambiental da SVMA, há uma preocupação em envolver toda a comunidade nas atividades dirigidas à preservação $\mathrm{e}$ a conservação do ambiente na Cratera, contudo, diversas dificuldades são referidas pelo técnico para desenvolver o trabalho de forma satisfatória.

Uma das dificuldades citadas reside no fato de se contar apenas com um profissional técnico para atender toda a complexidade e o conjunto de demandas de toda a APA. 
"Para desenvolver um trabalho efetivo com a população da Cratera seria necessário um profissional somente para esse fim, pois (...) um técnico somente, para atender toda a Cratera fica bastante prejudicado".

Objetivando informar a população sobre a importância astronômica, geológica e ambiental da Cratera da Colônia, a SVMA, por meio do DEPAVE 6 (Planetário e Escola Municipal de Astrofísica do Departamento de Parques e Áreas Verdes) e a DEAPLA (Departamento de Educação Ambiental e Planejamento) ofereceu no primeiro semestre de 2004 um curso intitulado "A Cratera da Colônia". O curso teve como público-alvo líderes comunitários, professores e educadores de nível médio e pessoas da comunidade interessadas no assunto. As aulas foram ministradas na sede da ACHAVE, uma vez por semana.

O curso versou sobre a importância astronômica, geológica e ambiental da Cratera, assim como as caracteristicas da Cratera da Colônia tais como: solo, clima, flora e fauna, o planejamento ambiental na região, entre outros temas.

Organizações da sociedade civil tais como o ISA - Instituto Sócio-Ambiental e SOS Mata Atlântica, também vêm atuando na área com a temática ambiental, especialmente no que se refere a mobilização da população em defesa dos mananciais. 
A SOS Mata Atlântica, dentro de seus projetos de Educação Ambiental vem desenvolvendo programa de monitoramento da qualidade das águas da região, com grupos da comunidade. Dentro do Condomínio Vargem Grande há dois grupos de monitoramento. Cabe destacar que no mês de setembro de 2004, a população da Cratera da Colônia esteve presente no evento promovido por ONGs ambientalistas e entidades governamentais no Dia Mundial da Limpeza, cujo objetivo foi promover uma grande limpeza nas margens da Represa Billings.

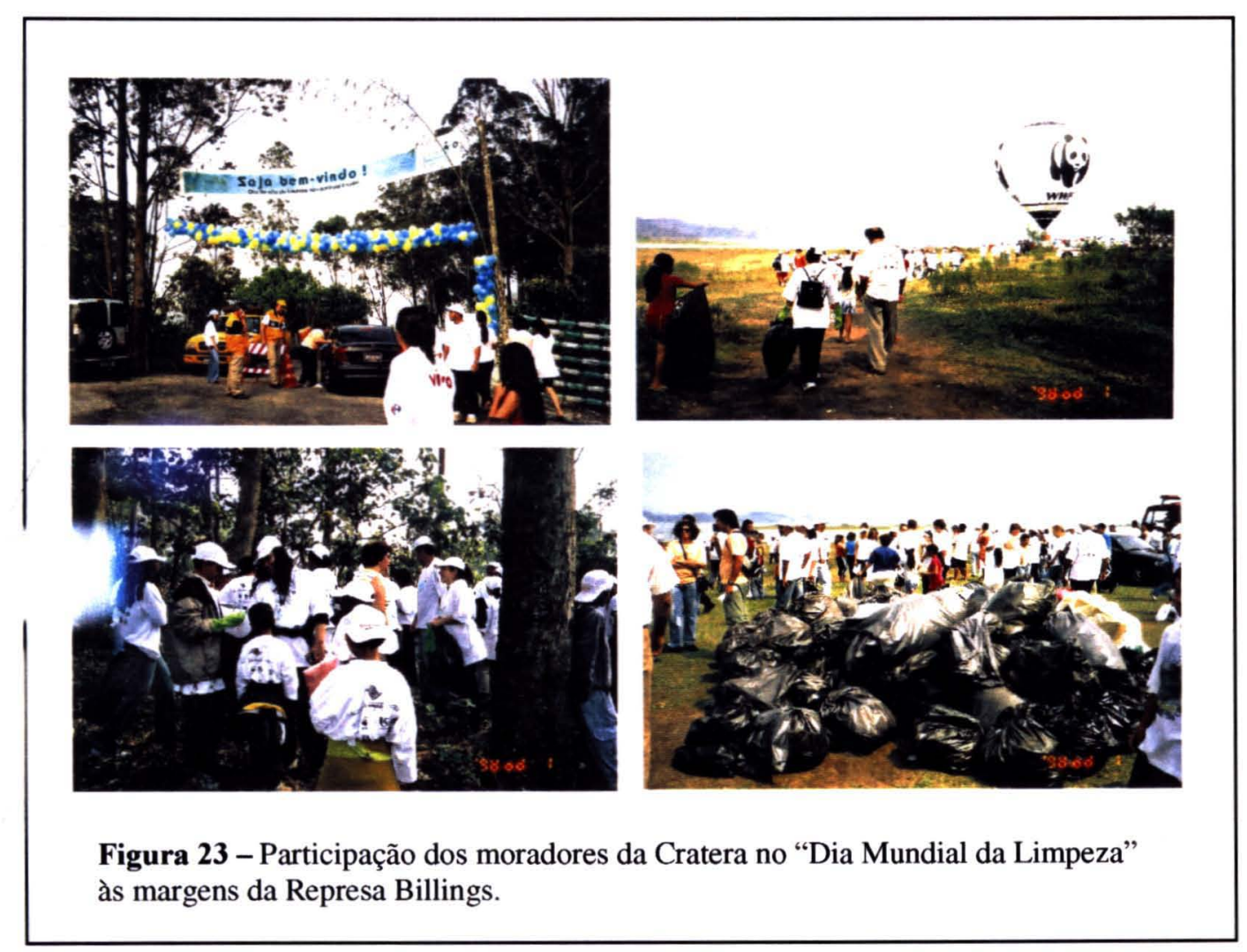

A ACHAVE também vem promovendo ações de educação ambiental envolvendo a população da região em diversas atividades, tais como:

○ Oficina de reciclagem;

- Construção de horta comunitária;

○ Mutirão do lixo;

○ Limpeza dos córregos atingidos pelo esgoto lançado pelo Presídio Estadual de Parelheiros; 
○ Oficina de panificação.

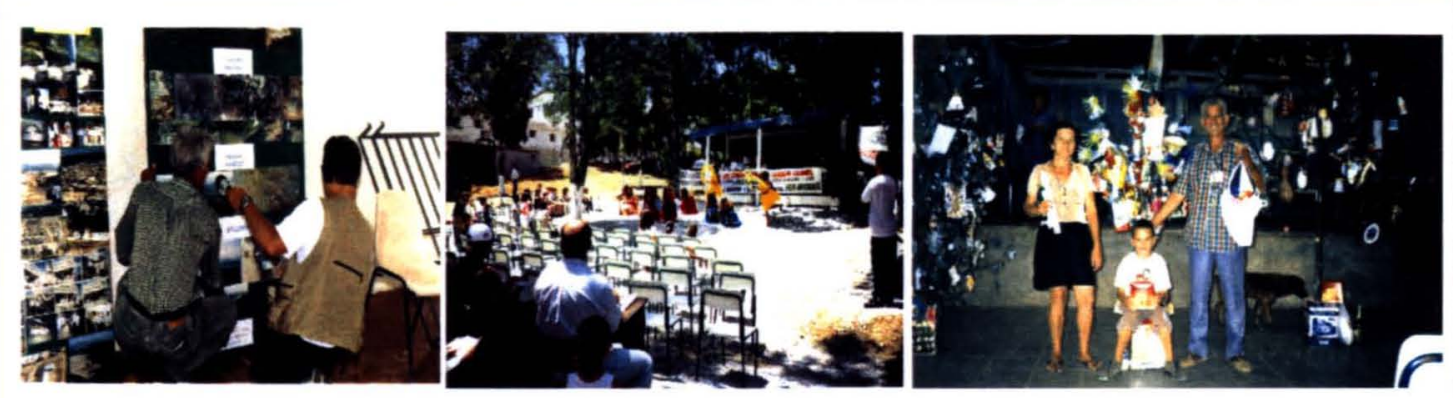

Figura 24 - Oficinas de Educação Ambiental e Reciclagem, promovidas pela ACHAVE.
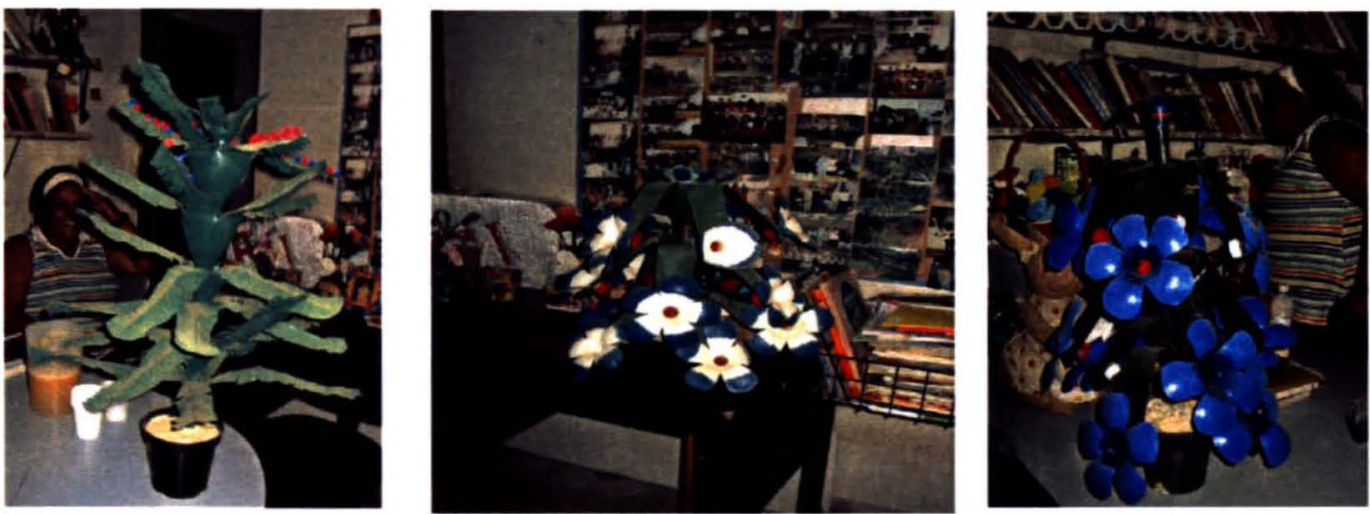

Figura 25 - Flores confeccionadas na Oficina de Reciclagem promovida pela AMUVE.
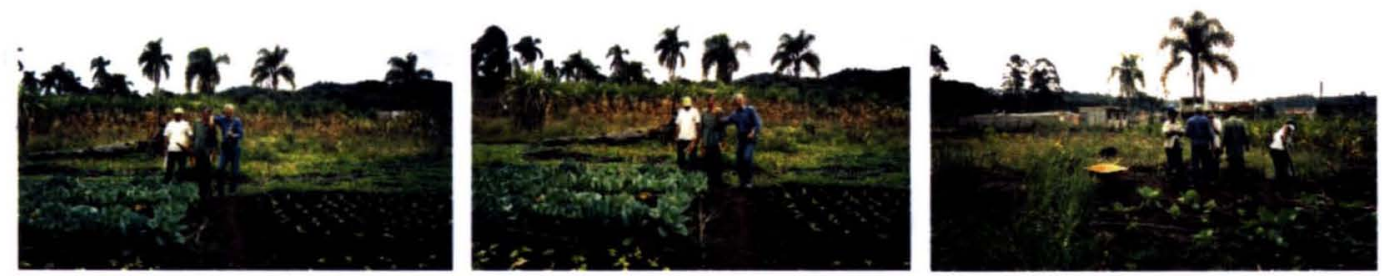

Figura 26 - Construção da horta comunitária. 


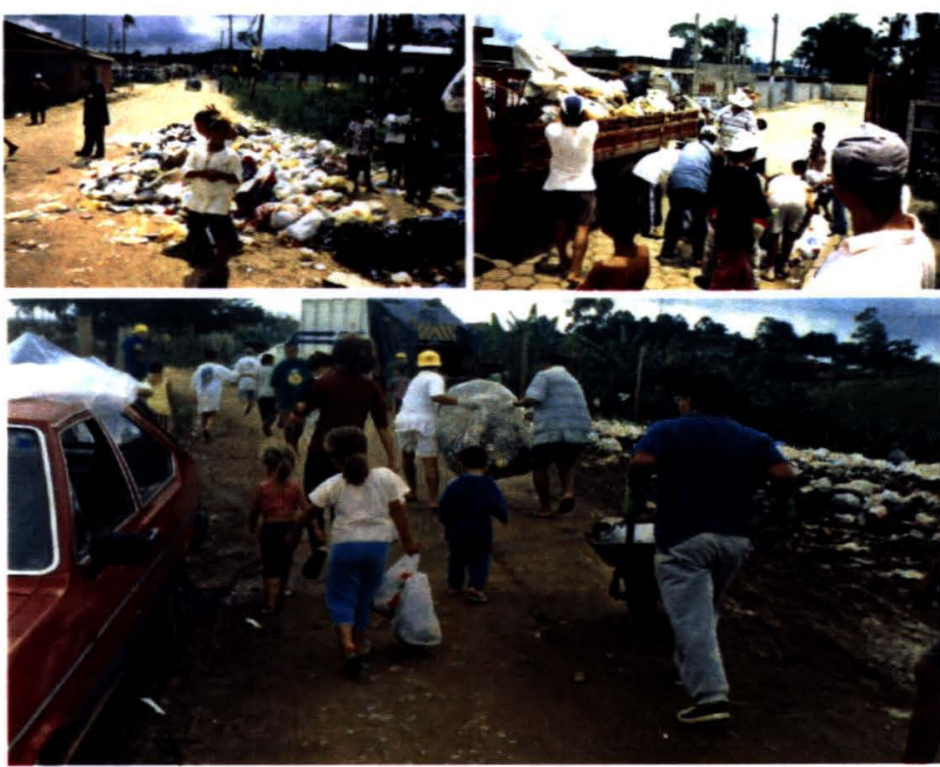

Figura 27 - Mutirão do lixo organizado pela ACHAVE.

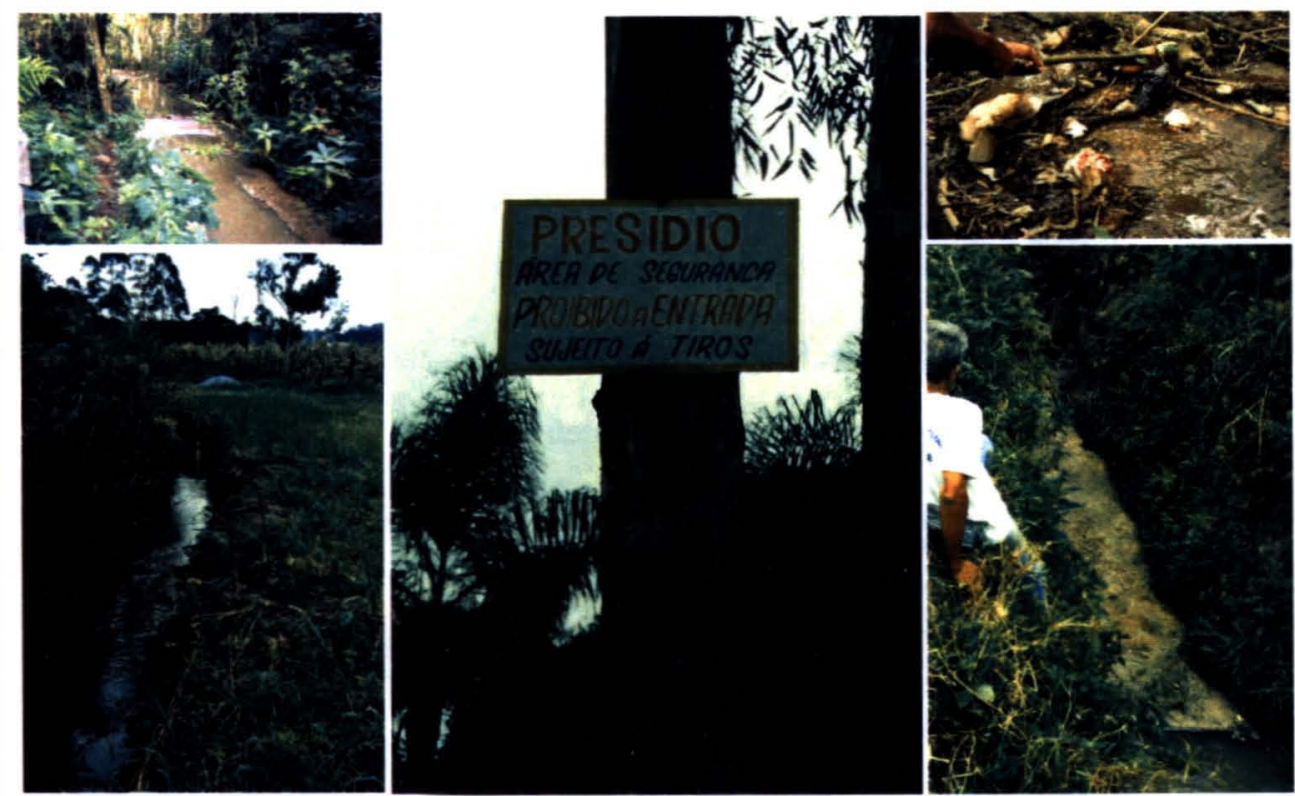

Figura 28 - Limpeza dos esgotos lançados pelo Presídio Estadual de Parelheiros. 

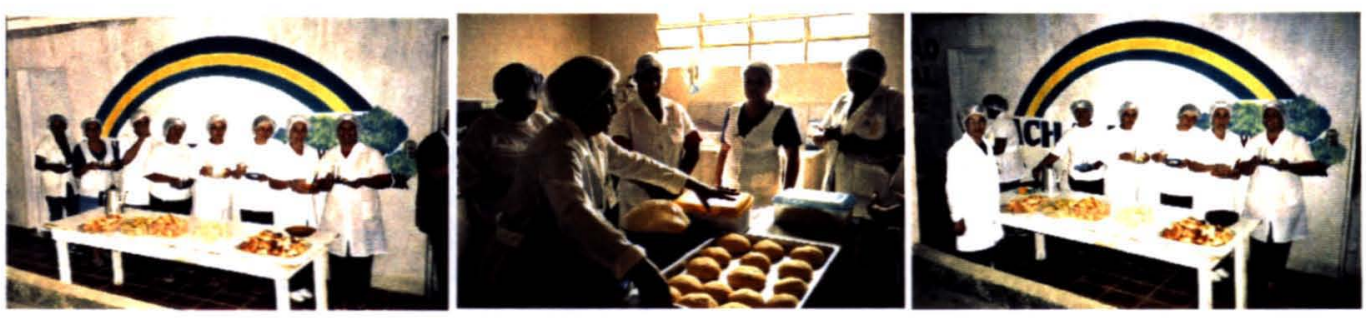

Figura 29 - Oficina de panificação implementada pela ACHAVE.
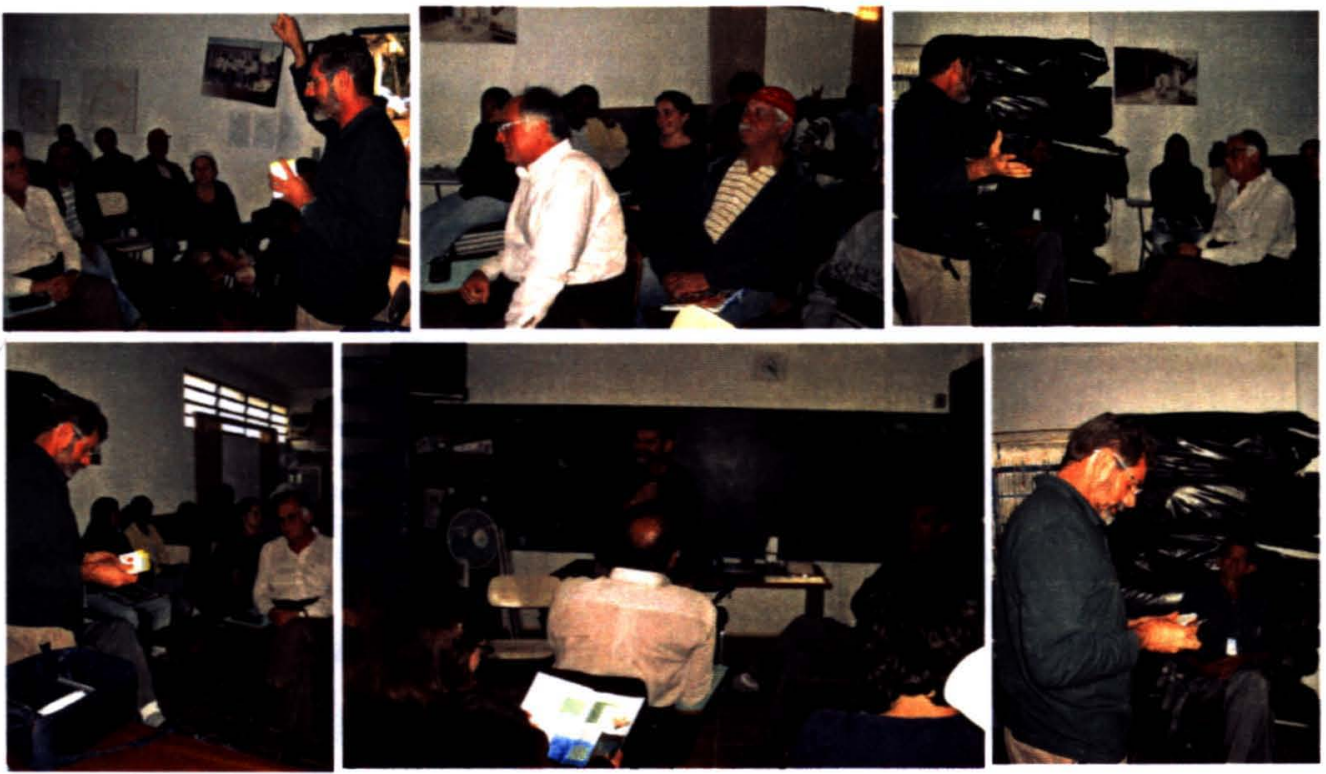

Figura 30 - Capacitação de monitores pela SOS Mata Atlântica. 
Dentre as ações de educação ambiental, os dirigentes da ACHAVE incluem o projeto de construção do asfalto "ecológico" como uma ação efetiva de educação ambiental.

“Veja bem como a gente já começava a se preocupar com a natureza e com a ecologia. Um dia estava vendo TV e vi que em Minas Gerais algumas cidades estavam desenvolvendo uma tecnologia para construir um calçamento que não degradasse ainda mais o meio ambiente. Quando vi aquilo fiquei louco para trazer aquilo aqui para Vargem Grande, tanto é que fui bater lá em Minas para conhecer a tal tecnologia. Voltando de Minas, escrevemos um projeto na Associação, fomos atrás de recursos e botamos a mão na massa para construir o calçamento ecológico!"

Os dirigentes da ACHAVE se auto-denominam "defensores da ecologia". Como ações importantes por eles referidas está a delimitação de uma área, de propriedade da Associação, para a construção de um parque ecológico, e a mudança dos nomes das ruas do condomínio. No início da ocupação as ruas eram identificadas por números; atualmente todas as ruas receberam nomes de árvores e de animais.

"Quando assumimos a direção da ACHAVE, tudo isso que você vê aqui (apontando para uma área na planta da gleba) já estava demarcado para venda. Nós, que a partir da conscientização que a gente foi adquirindo é que resolvemos não lotear mais $e$ transformar toda essa área num grande parque ecológico! Se fosse no tempo da Sipriana tudo isso aqui já estaria vendido!".

\subsection{As representações, sentidos e significados da questão ambiental para a população da Cratera da Colônia.}

As representações, sentidos e os significados atribuídos à questão socioambiental captadas por meio das falas da população que habita a área conhecida como Cratera da Colônia, tal como ocorre com as representações sobre qualquer 
tema, tendem a reproduzir as noções do senso comum circulantes na sociedade e são construídas socialmente (HANNIGAN 1995).

Os processos adaptativos humanos sempre dependeram da elaboração de representações e interpretações a respeito da natureza, e também das organizações coletivas e individuais da intervenção sobre ela. Por outro lado, as exigências dos interesses econômicos, os avanços das ciências, as modificações políticas e culturais provocaram mudanças que constituíram, segundo MOSCOVICI (1975), a história humana da natureza e sua representação, seu entendimento, sensibilidades que a acompanham. "Cada momento desta construção, como uma pauta musical, tem seu registro emitido no imaginário, na memória e nas práticas coletivas" (ARRUDA 1995).

Para BOURDIEU (1999), todas as relações estabelecidas pelo ser humano são dominadas pelo que se denomina "estrutura objetiva das relações", isto é, pelo espaço social que cada pessoa ocupa em decorrência de suas origens familiares, poder aquisitivo, nível de escolaridade e da ética que adquire, em função dessa mesma posição no campo social, que não deve ser confundida com o espaço geograficamente definido. Essa premissa talvez se constitua numa das explicações para diferenciações tão significantes entre as representações de homens e mulheres que ocupam a mesma área geográfica, a Cratera da Colônia, pois dentre os nossos atores e atrizes entrevistados existiam alguns que, em algum momento de suas vidas, fizeram cursos de educação ambiental, e outros não.

As representações de uma população que participa ou participou, em algum momento de suas vidas, de cursos relacionados à temática ambiental difere bastante daquelas que nunca freqüentaram nenhum curso (PALOS 2000). No caso da população da Cratera, as representações sobre a questão ambiental entre aqueles que participam ou participaram de cursos oferecidos, seja pelo órgão municipal de meio ambiente, a SVMA, seja pelo órgão estadual do meio ambiente, seja pela empresa concessionária do abastecimento público de água (SABESP), mostram-se bastante heterogêneas, sobretudo, em relação àqueles que nunca participaram dos cursos e aqueles que também não militam na Associação. $O$ grupo populacional que participou e ainda participa desses cursos apresenta, em sua grande maioria, uma 
representação de meio ambiente mais abrangente, incluindo não só os aspectos naturais, mas também o ambiente social e construído.

“(...) ambiente para mim é o conjunto de todas as coisas que compõem o espaço em que vivemos: a água, o ar, as plantas e os seres vivos dos quais fazemos parte. Para se ter um meio ambiente saudável, é necessário que não tenhamos desemprego, fome, habitação precária, falta de higiene, desnutrição, agressões à natureza como queimadas, desmatamentos, lixo jogado nas ruas e nos córregos, etc".

Dentre os componentes do grupo que tem participado com mais regularidade desses eventos, os significados sobre ambiente focalizam-se, principalmente, no espaço urbano e na qualidade de vida, sem dissociar-se natureza dos seres humanos. As representações que emergem dos discursos conseguem revelar as diversas faces complexas da realidade, deixando claro que a visão popular de ambiente, para as pessoas entrevistas, não é monolítica.

Para a maioria delas o processo é entendido de maneira holística, incluindo-se vários determinantes da degradação ambiental, tais como fatores sociais $\mathrm{e}$ desemprego, falta de lazer, falta de investimentos sociais, educação, falta de saneamento, problemas de saúde e de habitação. Denota-se, por meio das falas dos diversos interlocutores que vêm participando dos cursos oferecidos, que esses vêm incorporando, em suas práticas, o discurso dos diversos movimentos ambientalistas que lutam pela preservação da área.

"(....) ambiente para mim é tudo que diz respeito à vida das pessoas e dos animais: é a moradia, o trabalho, a comunidade a natureza humana e a natureza ecológica. É o espaço que habitamos!".

“(...) a natureza, o lar, a casa, o trabalho, o meio ambiente está também no interior da gente, é a gente estar bem com gente mesma(....)". 
“(...) Meio ambiente é tudo que eu vivo, minha casa, meu trabalho, a rua que eu moro, que eu passo. É qualquer lugar em que eu esteja independente da hora, é o meio que estou vivendo. São os meios ambientes interiores também. As coisas estâo todas interligadas, conectadas. Eu também faço parte do meio ambiente (....)".

O grupo da população pesquisada não-participante dos cursos oferecidos pelas entidades acima citadas possui uma grande dificuldade na explicitação do entendimento sobre o ambiente; muitas nem o conseguem e, quando o fazem, estas representações e significados estão sempre ligados ao meio natural, deixando explícita a cisão Homem-Natureza, visão esta construída ao longo da história do Brasil.

As palavras mais evocadas quando os entrevistados e entrevistadas se referiam ao ambiente foram: verde, natureza, preservação, desmatamento e árvores. Uma melhor compreensão das representações, sentidos e significados a partir de uma aproximação do contexto semântico desses elementos, sugere que esse grupo de entrevistados/as possuiria uma visão naturalizada da questão ambiental. Segundo DA MATTA (2003), o processo de naturalização está impregnado na cultura brasileira de tal maneira que a tendência do brasileiro é ler tudo como natural.

$$
\begin{aligned}
& \text { “...ambiente para mim é o verde, a natureza” } \\
& \text { “.... para mim ambiente é a natureza, é um lugar puro de } \\
& \text { meditação, é um lugar que a gente se sinta bem!” } \\
& \text { “...ambiente para mim é a preservação da natureza, do verde”. } \\
& \text { “....ambiente para mim é não desmatar, não cortar as árvores”. }
\end{aligned}
$$

Uma tônica recorrente em diversas pesquisas, (DA MATTA 2003, ARRUDA 1995; PALOS 2000) indica que, em grande parte dos discursos o meio ambiente é associado ao reino de Deus, em contraposição ao mundo dos homens. A idéia de 
meio ambiente emerge como uma construção divina, enquanto a espécie humana é um agente de destruição. Essa visão, segundo Da Matta (2003), é um denominador comum em torno de visão de natureza; para este autor a idéia circulante é a de que "a natureza é boa, mas a sociedade é ruim".

“... meio ambiente para mim é uma coisa divina. Só Deus teria todo esse poder para criar tudo de belo que temos na natureza: os rios, o mar, as estrelas. Quem mais poderia criar tamanha perfeição?"

“... meio ambiente para mim é uma obra do criador. Porisso temos o dever de respeitá-lo, assim como respeitamos o criador!".

“....ambiente para mim é um lugar cheio de harmonia $e$ felicidade!",

As representações e os significados de um fato não constam unicamente de representações engendradas pela realidade objetiva e concreta, mas estão igualmente compostas de juízos de valor e de crenças "fantasmáticas". Para o antropólogo Godelier o meio ambiente tem sempre dimensões imaginárias que, em alguns casos, podem ser o lugar da existência dos mortos, ou a morada de forças sobrenaturais benignas ou malignas que se supõem controladoras das condições de reprodução da natureza e da sociedade. "Tais representações dão sentido a certos comportamentos e a intervenções sobre a natureza que para um observador ocidental podem parecer totalmente irracionais" (GODELIER 1981, p. 55).

Para muitos dos entrevistados e entrevistadas, as representações sobre o ambiente onde vivem estão diretamente relacionadas a imagens e visões fantasmagóricas de que falam Godelier e Da Matta. Uma alusão bastante recorrente nas falas dos entrevistados é a existência de "sumidouros" e de "buracos que engolem árvores e outras coisas" em alguns pontos da Cratera. 
Essas representações, embora estejam permeadas de uma visão mítica da realidade, trazem em si explicações para um evento que a ciência pode explicar, que é o fato do solo de alguns pontos da Cratera estar sedimentado por turfas, apresentando dessa maneira, falhas na sedimentação.

Para DA MATTA (2003), essa visão mágico-religiosa está no cerne da visão de natureza do homem brasileiro. "O Brasil está cheio dessa visão que tem esse nivel de participação mágica, de se acreditar que o canto de um passarinho pode significar azar, que o sapo pode trazer sorte, que determinadas plantas protegem contra o " mau olhado"

Para este autor, a visão mágica não é necessariamente anti-ecológica, e a visão progressista também pode ser ecológica. Criando um tabu, ela pode impedir a exploração de determinados componentes da natureza, da mesma forma que dentro de uma visão progressista, o indivíduo pode transformar a natureza, preservando-a DA MATTA (2003). Da fala a seguir, em que o entrevistado refere-se à possibilidade de a Cratera da Colônia ter sido originada pela queda de um meteorito, pode-se depreender que uma visão mágica, de um morador da Cratera, poderia servir de argumento suficiente para a necessidade de conservar o ambiente natural da área.

"Para mim tudo isso é uma criação divina, eu costumo dizer que a Cratera é um lugar tão especial, mas tão especial, que guarda dentro de si um pedacinho do céu. Por isso nós temos o dever de preservá-la".

Uma visão mágico-religiosa pode coexistir com a visão "progressista" de domesticar, de transformar a natureza através da cultura, como é o caso do "povo brasileiro". É uma visão que está com a natureza para certas coisas, mas está contra elas para outras. São representações que parecem estar em competição uma com a outra, todavia, também são complementares.

Por meio das falas dos entrevistados apreendem-se várias passagens que ilustram esse pensamento, pois as mesmas pessoas que "falam que a natureza é divina, foi criada por Deus" ou que "o ambiente confunde-se com a natureza que foi 
obra do criador", tempos atrás, na época da ocupação da Cratera, destruíram a natureza com moto-serra.

A natureza edênica e dadivosa aparece também nas representações do ambiente natural dos entrevistados e entrevistadas. A crença na singularidade brasileira relacionada com a natureza exuberante, aliada à mistura de raças, está longe de desaparecer no redemoinho da modernidade, como menciona Da Matta (2003). Essa visão idílica de natureza exuberante persiste em expressões cotidianas do imaginário de homens e mulheres da Cratera da Colônia.

“Meio ambiente é tudo que vivemos, é tudo o que a natureza pode nos proporcionar, os mares, os rios, a terra. Veja por exemplo, no caso do Brasil, da Floresta Amazônica, aliás, não... nem precisa ir muito longe, veja o caso da nossa floresta aqui da APA, que maravilha, tem cachoeiras maravilhosas, tem até indio. Será que lá fora (exterior) tem tanta coisa bonita assim?"

Indagados sobre o por que da aproximação com a questão ambiental, todos se referiram ao fato de que a aproximação se deu em virtude das restrições e imposições legais, colocadas para a ocupação de seus lotes e para a construção dos equipamentos sociais necessários. Para esse grupo de moradores, anteriormente a esse fato, nunca haviam se preocupado com o assunto. Apoiando-se em HANNIGAN (1995), essa visão pode ser justificada pelo fato de que a preocupação do público sobre meio ambiente não seja algo automático, mesmo em situações ambientais extremamente adversas.

"Sabe porque que eu comecei a me interessar por esse tema de meio ambiente? Foi quando me deparei que, como estávamos numa área de manancial, não poderiamos construir a nossa tão sonhada casa. Ai eu fiquei revoltado, na época, me lembro que achava que esse coisa de meio ambiente veio para atrapalhar muito a nossa vida." 
“...não tinha a menor noção dessa temática ambiental, só vim a saber sobre isto quando começou o burburinho que não podiamos construir a nossa casa que tanto a gente sonhava. Ai a gente foi tomando conhecimento junto com o pessoal da associação!

Entre os depoimentos há uma referência à Conferência Mundial ECO-92, como a ação responsável por seu interesse pelas questões ambientais.

"O que me despertou mesmo para essa coisa de ecologia, foi a ECO-92. Ali que eu me conscientizei que a coisa era mesmo séria. Até então eu achava que essa coisa de nos incriminar por agressão ao meio ambiente era coisa de perseguição. Porque você veja só, era sós nós que estávamos recebendo multa, o Presidio não!.

O papel desenvolvido pela ciência e pelos meios de comunicação social se constituem em importantes arsenais no que se refere ao conhecimento, crises e soluções na formulação da problemática e dos riscos ambientais, como alerta HANNIGAN (1995).

Diversas pesquisas apontam o importante papel que a mídia exerce na construção das representações sobre meio ambiente, em diversos segmentos sociais, sobretudo para uma população que obtém informações e formação sobre o tema, principalmente, através dos meios de comunicação de massa.

As representações estabelecidas ao longo do tempo são fruto de heranças cognitivas e simbólicas, fundidas à estranheza do novo - no caso, a crise ambiental. "São edificios que partem de raizes históricas e coladas às práticas que vão se desenvolvendo" (ARRUDA 1995).

No caso da população da Cratera foi a estranheza do novo que mobilizou a conscientização para as questões ambientais. $O$ fato de conseguir ser proprietário de um pedaço de terra, e nela não poder construir, porque o local estava protegido pela 
lei de proteção dos mananciais caiu como um outro meteorito para aquelas pessoas, que nada mais possuiam na vida, em termos materiais, a não ser aquele lote duramente adquirido. Isso fez com que essas pessoas passassem a aproximar-se da problemática ambiental por absoluta necessidade de resistência.

"Ou a gente se organizava e tentava entender a situação para solucionar o nosso problema, ou a gente perdia tudo que tinha conquistado na vida".

A ocupação que foi se estabelecendo na região esteve, inicialmente, calcada na lógica predatória, fruto do descaso do poder público, sem uma preocupação com o equilibrio ambiental; todavia, com o passar do tempo e com as dificuldades que foram encontrando no caminho para a concretização da ação, a questão ambiental foi se mostrando como um desafio a ser enfrentado.

"O ambiente aqui na Cratera era uma beleza quando nos compramos a gleba, mas fazer o que né, nós empatamos todo o nosso dinheiro para ter um lugar para morar né, ai cada um que ia chegando ia desmatando todo o seu lote para construir sua casinha!"

Com a chegada de novos proprietários, os desmatamentos foram se intensificando e alterando significativamente a paisagem do lugar. Tais acontecimentos não são fatos isolados mas são frutos do processo histórico da urbanização da cidade de São Paulo.

As contínuas intervenções que o ambiente vem sofrendo, ao longo dos anos, têm alterado sobremaneira a área conhecida como Cratera da Colônia.

$\mathrm{O}$ antropocentrismo, tão enraizado no imaginário dos homens e das mulheres e tão presente na formação das sociedades, com certeza, provoca desequilíbrios e rupturas nesta relação tão sensível, que é a do homem com a natureza, e que, segundo Arruda (1995), é uma construção social, seja do ponto de vista físico, seja do ponto de vista simbólico. As representações e os diversos significados não são 
divorciadas da sociedade que as cria, da forma como ela se organiza e estabelece relações no seu interior, entre os humanos e destes com a natureza (ARRUDA 1995).

Pela leitura das entrevistas percebe-se uma interligação nítida entre a saúde e os fenômenos da natureza, no plano das representações da população da Cratera da Colônia. $\mathrm{O}$ ar puro e a vida ao ar livre são fatores de saúde, enquanto que a poluição do ar e das águas, através da intervenção desordenada do homem na natureza, constituem explicação para muitos males tais como diarréias, alergias, hepatites, problemas de pele.

As representações de saúde associadas a um ambiente saneado também se fazem recorrentes em vários depoimentos.

"A saúde é fundamental nos seres vivos. O ar contaminado é fatal, o meio em que vivemos tem que ser limpo e saudável".

“Saúde para mim é ser saudável, morar num ambiente limpo, sem poluição, porque a doença tanto pode vir do nosso organismo como também do meio ambiente, né?".

Um elemento constitutivo central das representações, significados e sentidos atribuídos à questão ambiental estabelecida na Cratera, tanto do ponto de vista pessoal de uma grande parte das pessoas entrevistadas, quanto do ponto de vista organizacional das entidades presentes na Cratera da Colônia, é a questão relativa à preservação da fauna e da flora local o que se tornou uma questão de honra para os ocupantes da Cratera. Esta questão tem mobilizado grande parte dos esforços empreendidos pela Associação Comunitária, no sentido de preservar o que restou da vegetação e da fauna local.

"Há evidências de que muitos moradores aqui da Cratera têm posturas bastante agressivas com relação ao meio ambiente: muitos moradores jogam lixo na rua, nos córregos, muitos comem macaco e outros animais silvestres que tem ai na mata, 
muitos caçam passarinhos para vender... A gente precisa conscientizar esse povo que isso não é bom para o ambiente".

Na Rádio Comunitária, a preservação da fauna e da flora também consiste no grande tema de sua programação. Posturas nocivas à preservação do ambiente também são ressaltadas e criticadas durante o programa "Ecologia e Educação Ambiental", tais como: o descarte de lixo nas ruas e nos córregos; o despejo dos dejetos diretamente nas ruas e córregos; o desperdício de água, entre outros temas relativos ao ambiente.

Em contraposição a essas atitudes negativas com relação ao ambiente, uma maior harmonia na relação homem-natureza é a tônica que permeia toda a representação sobre a questão ambiental que emerge na programação da rádio.

A imponência da natureza, expressa na pujança do nosso planeta, é destacada o tempo todo na programação, conclamando os ouvintes a execução de sua parte na salvação, ou seja preservando a fauna e a flora e não tendo atitudes negativas e predatórias com relação ao ambiente natural.

"O nosso grande patrimônio que é o nosso ambiente, a nossa natureza está ameaçada de destruição de tantas agressões que vêm sofrendo. Precisamos conscientizar essa população que ela tem um papel importante na preservação dessa riqueza para os nossos filhos e netos"

Como fonte de informações para embasar a programação da rádio, o condutor do programa afirma pesquisar diversos boletins informativos da Secretaria do Verde da Prefeitura de São Paulo, da Secretaria do Meio Ambiente do Estado de São Paulo, da CETESB, e principalmente nas revistas. Como já citada anteriormente, a revista "Terra" da Editora Abril foi citada como a principal fonte de informações para o embasamento ambiental teórico a ser transmitido aos ouvintes. Foram também citados alguns cursos patrocinados pelas Secretarias da Prefeitura e do Estado. 
Fica bastante evidente, a partir da fala do entrevistado, a ênfase que é dada a posturas positivas individuais dos moradores com relação à solução dos problemas ambientais, tais como: comunicar a associação de moradores sobre ocupações indevidas; comunicar à associação eventuais desmatamentos que porventura estejam acontecendo; cuidar do seu "pedaço", por exemplo, plantando uma árvore na frente de sua casa; acondicionando seu lixo devidamente e o colocando na rua somente nos dias em que passa o lixeiro; não jogando dejetos diretamente nas ruas ou em córregos, entre outras.

De acordo com os entrevistados da comunidade, "as reduzidas informações" de que dispõem sobre a questão ambiental viriam dos meios de comunicação de massa, principalmente da televisão. Muitos deles citaram o programa da rádio local sobre educação ambiental e o "Globo Ecologia" como uma fonte de educação e informação.

\subsection{Comparando os grupos por gênero}

Quando comparados, os grupos de interlocutores homens e mulheres, pode ser percebida uma demarcação bastante tênue entre os dois grupos: enquanto nas representações do grupo dos homens fica muito mais evidente a associação de ambiente com o ambiente natural, associando-se ambiente à natureza, rios, árvores, ao "verde", no grupo de mulheres a associação é basicamente ligada à qualidade de vida, a problema social e bem-estar, embora a visão feminina abarque também o ambiente natural como a mata, os rios, a fauna.

"Para mim a questão ambiental tem tudo a ver com o verde, com a mata, com os rios, com os pássaros. É um grande prazer poder usufruir dessa natureza que Deus nos deu. Sempre fui muito ligado à natureza desde menino. Acho que eu sou descendente de indio". (Entrevistado do sexo masculino)

"Ambiente, na minha maneira de ver, está relacionado com qualidade de vida. É a gente ter um bom emprego, ter uma 
habitação digna, ter acesso ao serviço de saúde, e ter também uma natureza preservada! (Entrevistada do sexo feminino)".

No grupo de mulheres pode ser encontrado, nas representações de ambiente, uma conotação muito mais humana do que no grupo de homens: enquanto nas representações delas há sempre uma aproximação do ser humano com o ambiente, nas representações do grupo de homens os seres humanos representam "a praga predadora do meio ambiente".

É bastante nítido, no grupo de homens, a associação que estes fazem da degradação ambiental com o aumento da população. Para eles, o aumento populacional gera poluição, barulho, violência e faz-se necessário um controle populacional, por meio de educação às famílias no planejamento familiar.

Já para o grupo de mulheres, uma associação bastante presente em suas representações sobre as causas da degradação ambiental é com relação à falta de melhores condições de vida para a população mais pobre, aliada à falta de políticas públicas que atendam as famílias quanto à educação sexual e ambiental. Apontam como perspectivas para a solução dos problemas a melhoria das condições de vida $\mathrm{e}$ a revalorização do indivíduo, por meio de políticas de inclusão das populações mais pobres, especialmente referindo-se aos mais jovens. No que se refere ao controle populacional, esta questão remete a um grande risco, na autonomia das mulheres de decidirem sobre sua vida sexual, é o que dizem as entrevistadas mais ativas politicamente.

$\mathrm{Na}$ Cratera da Colônia, assim como em muitas outras localidades do Brasil, muitas mulheres, por falta de condições na infância ou na adolescência, tiveram de interromper seus estudos e, na vida adulta, em razão de compromisso familiares, principalmente com o cuidado com os filhos, nunca mais puderam continuá-los, o que também foi demonstrado em investigações realizadas por ZIONI (1994), BÓGUS (1997) e PALOS (2000). Esse fato dificulta ainda mais o acesso ao mercado de trabalho. Embora muitas dessas mulheres tenham uma função preponderante dentro do sistema econômico, esta não é valorizada, nem mesmo entre as próprias mulheres. 
Para CALIÓ (1991), o trabalho doméstico é definido como todo o trabalho que envolve as tarefas cotidianas da vida familiar, e está reservado a todas as mulheres de forma marcante. Pelo fato de ser gratuito e estar fora das relações de mercado, tal trabalho é desconsiderado enquanto "trabalho real" e, por conseguinte, excluído do pensamento econômico.

Desconstruir essas representações é um dos grandes desafios para as mulheres desse início de século, se quiserem vislumbrar uma sociedade onde haja um equilibrio entre os gêneros masculino e feminino. O movimento feminista, ao longo dessas últimas décadas, vem contribuindo de forma decisiva para que esse processo torne viável para a sociedade e, principalmente, para as maiores interessadas, no caso as mulheres (PALOS 2000).

Diversos trabalhos desenvolvidos com grupos de mulheres têm revelado significativas transformações a partir do ingresso dessas mulheres a grupos de reflexão. Transformações estas que não se reduzem apenas ao aspecto de sua inserção no mundo do trabalho, mas também em repercussões nas outras esferas da vida particular.

ZIONI (1994), BÓGUS (1997) e PALOS (2000) são algumas pesquisadoras que, em seus estudos, apontaram para a ocorrência de mudanças nas vidas pessoais de participantes de movimentos de associativismo civil e de movimentos sociais ocorridos no Brasil, especialmente nas duas últimas décadas do Século XX.

Em diversos depoimentos, foi enfatizada a participação nos movimentos implementados na Cratera da Colônia como um fator preponderante, não só para o aumento do conhecimento, no que se refere aos aspectos cognitivos da questão ambiental mas, principalmente, no tocante às reflexões sobre a subordinação e dominação contidas entre os gêneros masculino e feminino, o que bem apontaram ZIONI (1994) e PALOS (2000) em suas investigações.

Alguns depoimentos demonstraram que muitos maridos, depois que suas mulheres passaram a fazer parte da associação, estão transformando também suas visões de mundo no que se refere a uma maior equidade nas relações entre os gêneros. 
Emergiu em diversos depoimentos uma preocupação constante com as jovens da Cratera. Diversas entrevistadas referiram-se à precocidade com que as meninas estão iniciando a vida sexual, o que tem aumentado o índice de gravidez na adolescência. A iniciação sexual precoce aliada à falta de informações e ausência de um eficiente serviço de saúde tornaria praticamente impossível a consecução de um planejamento familiar adequado.

Foi possível captar, nas falas de diversas mulheres, que as líderes do movimento aparecem como impulsionadoras de uma nova postura e de uma nova prática social. Essas líderes fazem a ligação das coisas práticas do cotidiano com as circunstâncias políticas, uma vez que essas lideranças foram sendo construídas e exercidas de uma maneira espontânea, conforme foram surgindo as necessidades.

\subsection{Os Problemas Ambientais na Cratera da Colônia}

Os problemas ambientais que emergiram nos discursos dos entrevistados e entrevistadas apareceram quase sempre interrelacionados, seja com problemas de saúde seja aos problemas sociais corroborando a investigação efetuada por PALOS (2000).

Conforme já exposto, os grandes problemas sociais caminham lado a lado com os ambientais pois, no quadro da degradação ambiental está embutida a deterioração social provocada, pela crise econômica e política crônica.

Desde a Conferência de Estocolmo, em 1972, as entidades ambientalistas já pressionavam os governantes, para que fossem levados em conta os aspectos sociais da questão ambiental.

Apesar do problema ambiental não ser um monopólio dos países ditos do Terceiro Mundo, a qualidade de vida e as condições ambientais nestes países são muito mais nefastas quando se observam os resultados causados pelas desigualdades sociais. Exemplos de tais resultados são as condições precárias vivenciadas pelas populações de cortiços, favelas e moradias de bairros periféricos das grandes cidades, como é o caso da Cratera da Colônia. 
Os problemas socioambientais, segundo a fala das mulheres e dos homens da Cratera, são enumerados a seguir:

\subsubsection{Desemprego}

Dentre os problemas ambientais presenciados na Cratera, na grande maioria dos discursos, emergiram como os maiores problemas do local o desemprego e todas as suas conseqüências, tais como: habitação precária, falta de oportunidades para os jovens, fome, desnutrição e degradação ambiental.

"Para mim o maior problema aqui na Cratera é o desemprego. Porque se a pessoa tem um bom emprego, se ela tem um bom salário, é lógico que ela vai se dar melhor na vida. Aqui no bairro que mais a gente precisa é de emprego. Pois se elas (as pessoas) não têm emprego, como que elas vão se sustentar e sustentar a familia? Se tivesse mais empregos para os homens, mulheres $e$ jovens do bairro, a situação seria bem diferente, a saúde iria melhorar, com certeza o meio ambiente também iria melhorar".

“Aqui na Cratera o que mais afeta a qualidade de vida é o desemprego, pois o povo não tem emprego. Aqui nós já temos grandes problemas com poluição da água, com o lixo, com a falta de esgoto mas, acho que nós temos o maior deles que é a falta de emprego, que afeta todo o resto. Um povo sem emprego é um povo triste, sem perspectivas (...)".

O desemprego vem se impondo como um dos principais problemas das sociedades contemporâneas, que já se prenunciava desde as últimas décadas do século XX. A crise do emprego que era um problema enfrentando pelos países pobres desde a década de 1970, vem atingindo as principais economias desenvolvidas do mundo. $\mathrm{Na}$ Europa, esse fenômeno está associado principalmente à crise do Estado de Bem Estar (Welfare State), sistema de políticas sociais construído 
no período pós a segunda guerra, que tinha como base política um pacto socialdemocrata e que incluía entre suas diretrizes o pleno emprego (GIDDENS 1998; SANTOS BS 1995; ZIONI \& PALOS 2000).

Este pacto propiciou aos países capitalistas um período de grande prosperidade, que atingiu seu apogeu nas décadas de 1950 e 1960 e que ficou conhecido como "era dourada" do capitalismo. O êxito da política de pleno emprego, combinado com o aumento da proteção social assegurada pelo Estado, serviu não só para dinamizar as economias dos paises centrais, mas também para deter um possível avanço do comunismo (ZIONI \& PALOS 2000).

Porém a partir da década de 1970, quando eclodiu a chamada "crise do petróleo", o crescimento econômico começou a enfrentar grandes dificuldades e a política do pleno emprego foi abandonada. A crise do Welfare State levou, conseqüentemente, a uma implosão do pacto social democrata e o neoliberalismo, ideologia centrada na crítica ao intervencionismo do Estado, ganhou projeção política sob a denominação genérica de "Estado Mínimo" (ZIONI \& PALOS 2000)

O processo de globalização da economia e os avanços tecnológicos atingidos na década de 1980 contribuíram, juntamente com a hegemonia alcançada pelo neoliberalismo, para o agravamento do problema do desemprego, tanto nos países desenvolvidos quanto nos subdesenvolvidos ou em desenvolvimento, que ainda não contavam com as conquistas de um Estado de Bem-Estar Social (ZIONI \& PALOS 2000).

Os ajustes neoliberais, aplicados pelos países da América Latina a partir de meados da década de 1980, seguindo as recomendações do "Consenso de Washington", agravaram violentamente as já precárias condições sociais, aumentando, conseqüentemente, a pobreza e a desigualdade em todos os paises da América Latina. "Houve uma ampliação das diferenças de acesso aos bens e serviços que satisfazem as necessidades básicas vinculadas à habitação, a seus serviços, à educação e à saúde" (SOARES 1998).

As políticas econômicas adotadas pelos governos vêm contribuindo, de forma decisiva, para o aumento do desemprego em muitos países. No que se refere ao 
Brasil, o agravamento do desemprego e da precariedade das condições de trabalho constitui-se numa das conseqüências mais dramáticas da política social e econômica desenvolvidas desde os últimos anos do Século XX. As parcas políticas sociais até então conquistadas nas áreas da saúde e da educação passaram a ser substituídas por práticas minimalistas de combate à pobreza, nas quais a focalização e a seletividade constituem-se como atributos das novas políticas sociais (SOARES 1998, ZIONI \& PALOS 2000).

Assim como a saúde, a educação e a habitação, o meio ambiente também vem sofrendo as conseqüências do aumento do desemprego e da pobreza, agravadas pelas drásticas políticas de ajuste para a América Latina. De acordo com SOARES (1998) um representante da OMS destaca que "o descuido com as obras de saneamento ambiental, o estado lamentável da infra-estrutura de saúde e o desabastecimento de água são fatores que podem converter a epidemia da cólera em uma endemia num futuro imediato", própria de situações de extrema pobreza.

O recrudescimento da pobreza absoluta no Brasil, que assola as cidades brasileiras, assim como as regiões periféricas das grandes cidades, fica melhor evidenciado quando se levam em conta as carências na acessibilidade aos serviços básicos de abastecimento de água, rede coletora de esgotos, coleta de resíduos sólidos, saúde, educação, habitação, condições básicas para uma boa qualidade de vida que dependem, essencialmente, de investimentos do setor público.

Os problemas apontados pelos entrevistados da Cratera da Colônia estão estreitamente vinculados aos desajustes sociais, causados pela política neoliberal estabelecida para os países da América Latina como um todo, os quais vêm causando conseqüências graves ao ambiente e à saúde.

\subsubsection{A violência}

De acordo com os entrevistados e as entrevistadas, a violência apresenta-se como um dos mais graves problemas socioambientais da Cratera da Colônia. Casos de homicídios são comuns na região acometendo principalmente a população de jovens entre 15 e 24 anos. 
"Aqui no Vargem Grande um dos graves problemas é a violência. Não passa uma semana sem que apareça uma pessoa morta ou por tiro ou por facada.E na maioria dos casos esses mortos não tem mais que 20 anos, é uma judiação!'”.

“Violência aqui no bairro tem demais. É gente morta por briga por causa de droga, principalmente entre os mais jovens. $\dot{E}$ gente morta por brigas em bar. É mulher que apanha do marido. Enfim a violência aqui é muito grande. Não sei onde vamos parar com tudo isso!".

"Aqui no Vargem Grande a perspectiva de uma vida melhor está muito distante de ser alcançada, principalmente para os mais jovens. O destino para esses jovens ou é morte por homicídio ou é cadeia. Não tem outro caminho se a coisa continuar como está!".

Essa informação é corroborada pelas estatísticas oficiais de mortalidade por causas de óbitos, na cidade de São Paulo. Como já referido anteriormente, o subdistrito de Parelheiros é um dos lugares onde se concentra o maior índice de mortes por homicídios no município. De acordo com os dados da Fundação SEADE (2004), o número de homicídios entre os homens de 15 a 24 anos, nesta região, de 2000 a 2002, foi acima de 350 mortes por 100 mil habitantes, enquanto a taxa de mortalidade total entre homens da mesma faixa etária, no município é de 247 pessoas.

Ainda, de acordo com os dados da Fundação SEADE, se tomados como base os números atuais, para quem vive em subprefeituras onde há o maior número de população jovem de todo o município, como é o caso de Parelheiros, subdistrito que possui a maior taxa de população jovem da cidade $(33,4 \%)$, as perspectivas de sucesso no mercado de trabalho são baixíssimas, uma vez que a média de estudo não chega a sete, e os empregados formais não chegam a $1 \%$ do total da cidade. 
Indagados sobre as razões para o alto índice de criminalidade no local, muitos entrevistados se referiram à falta de um projeto de vida para os jovens do bairro, que encontram na criminalidade uma alternativa de vida.

"Não há uma perspectiva para os jovens daqui. Falta estudo suficiente, falta lazer, falta cultura! Falta um projeto que incluam esses jovens em ações que ofereçam uma melhor perspectiva de vida para eles, porque, se não existe, é claro que eles vão se envolver com a criminalidade. É uma forma de inclusão, de se dar bem na vida." (Médica do PSF)

M.S., 19 anos, jovem morador de Vargem Grande, é um exemplo típico do que é ser jovem nas periferias da cidade de São Paulo, especialmente, na Cratera da Colônia. De acordo com seu relato, parou de estudar na quarta série do ensino fundamental e cansou de presenciar amigos, que entraram para a vida do tráfico de droga ou que já morreram assassinados em decorrência de brigas entre traficantes. No momento da pesquisa, MS estava desempregado, e para sobreviver, caçava passarinhos para um amigo, que por sua vez, os vendia para pessoas externas à Cratera.

\subsubsection{A poluição das águas}

Embora a poluição das águas se constitua num problema ambiental grave, na visão de todos os entrevistados, tanto homens quanto mulheres, não aparece uma consciência da dimensão da problemática ambiental, em torno da questão, fruto do grande conflito que se estabelece na Cratera da Colonia. Somente os dirigentes comunitários têm a real dimensão da problemática, uma vez que muitos deles militam nos movimentos: Área de Proteção e Recuperação dos Mananciais-Billings; Comitê da Bacia Hidrográfica do Alto Tietê, Subcomitê Billings-Tamanduateí, entre outros. 
As respostas parecem apontar que, como a Cratera da Colônia é servida por rede de abastecimento proveniente de poços artesianos, a questão da água não é um problema sentido atualmente pela população. Quando se referem a problemática em torno da questão da água, remetem-na a um passado bastante longínquo e a um espaço longe dali - no caso, as regiões centrais do município de São Paulo.

Muitos dos entrevistados e entrevistadas enfatizam que já ouviram falar bastante sobre o problema da água, mas quando se pede para que expliquem com mais detalhe a questão, a maioria deles não sabe fazê-lo. Poucos conseguiram falar sobre o significado dos mananciais da região no contexto de uma problemática que extrapole a questão local.

A maioria dos entrevistados e entrevistadas, embora já tivessem ouvido falar sobre a APA - Capivari - Monos, quando era pedido para que explicitassem com mais detalhes as ações da APA, não soube fazê-lo.

\subsubsection{Alcoolismo e drogadição}

O alcoolismo apresenta-se como outro problema grave para a maioria das entrevistadas. O uso do álcool, mais ou menos generalizado, principalmente pelos homens do Condomínio, poderia ser o responsável por desajustes familiares e comunitários. Embora o alcoolismo não seja um hábito predominante em nenhum grupo etário, há referências de que muitos jovens já fariam uso do álcool na Cratera da Colônia.

Como já havia evidenciado em outro estudo, fora do município de São Paulo (PALOS 2000), durante o período da pesquisa de campo, na Cratera da Colônia, também foi possivel constatar a presença de vários homens alcoolizados, pelos bares da região. A partir de contato com a então diretora da Unidade Básica de Saúde do Condomínio, esta mencionou que o problema do alcoolismo apresenta-se como uma das queixas mais corriqueiras no serviço de saủde.

A drogadição foi também um problema mencionado por um número bastante expressivo dos entrevistados, e uma das causas que contribuem para o alto índice de criminalidade no local. 


\subsubsection{Serviços de saúde}

Embora, em primeira instância, o processo saúde e doença seja explicado pela população da Cratera da Colônia a partir de vários fatores, a falta de qualidade dos serviços de saúde foi apontada, unanimemente, por todos os entrevistados, como um dos principais problemas do Condomínio, o que se traduz numa descrença generalizada nos serviços de saúde oferecidos.

\subsubsection{Desmatamento}

O desmatamento aparece também como um dos principais problemas ambientais, segundo as representações da população da Cratera da Colônia, o que repercute na piora da qualidade ambiental da região.

A redução do número de espécies animais e vegetais é um dos problemas associados ao desmatamento, segundo os entrevistados.

“O meio ambiente aqui Cratera piorou muito de uns anos para cá, acho que depois que vieram essas pessoas lá da Favela das Águas Espraiadas. Quando a gente veio para cá, tinha muita mata ainda, mas com a chegada de mais e mais moradores, que foram chegando e desmatando ainda mais, a situação piorou muito".

"Quando a gente veio morar aqui na Cratera era muito bom, tinha muita mata, muitos bichos. Tinha macaco, tinha tatu, tinha cada passarinho bonito que você precisa de ver! Agora depois que muitas pessoas descobriram a Cratera, a coisa está ficando muito ruim. Até os bichos sumiram!".

Emergiram das representações de homens e mulheres, tanto entre as pessoas mais velhas que vivenciaram o processo, quanto as mais jovens, uma certa nostalgia em relação ao passado que, no caso dos mais jovens, está bem próximo, tomando 
como referência que a ocupação massiva aconteceu no início dos anos 1990. Naquela época, para as pessoas entrevistadas, havia mais lazer e mais qualidade de vida. $O$ presente, por sua vez, aparece invariavelmente associado a uma certa fatalidade no que se refere à qualidade ambiental do lugar, como se a degradação ambiental fosse o outro lado da moeda do desenvolvimento social e econômico.

Segundo REIGOTA (1999), mesmo entre os/as ecologistas existem aqueles que tentam uma volta ao passado mítico e idealizado, imaginando que neste passado havia uma melhor qualidade de vida, desprezando dessa forma as conquistas técnicas, sociais e culturais e propondo uma vida mais rude e "natural".

Representações como estas necessitam ser descontruídas e, para que isso ocorra, são necessários diálogos constantes, entre os diferentes conhecimentos e representações que mobilizem ações e estimulem mudanças concretas no presente cotidiano (REIGOTA 1999).

Dentre os entrevistados e entrevistadas que de alguma forma participam das associações civis da região o desmatamento se configura como um dos principais problemas ambientais da região.

Todo o dia tem gente queimando a mata, principalmente no final da tarde: quando desce aquela cerração as pessoas aproveitam para por fogo na mata, porque ai se confundem fumaça $e$ cerração!

"Desmatamento aqui tem todo o dia. Só para você ter uma idéia outro dia um sujeito que tem uma propriedade lá para os lados do encontro do Rio Capivari com o Monos, desmatou um tantão de mata ciliar que é considerado um crime ambiental gravissimo, este ainda a gente ficou sabendo e o cabra foi multado, mas quantos por ai que a gente nem fica sabendo e nem acontece nada com o sujeito!". 
Quando indagados sobre a fiscalização na área, os entrevistados se referiram ao fato da região possuir oito policiais florestais, mas que, na prática, não exercem a função para a qual foram designados.

"Eu já cansei de chamar a polícia florestal quando acontecem os desmatamentos e queimadas, mas eles nunca nos atenderam!".

“Esses policiais florestais que têm aqui é só para inglês ver, pois na prática nada resolvem. Dizem por ai que só dar uma caixinha para eles e tudo fica por isso mesmo!".

“As Associações Comunitárias da região é que fazem o papel de policia aqui dentro. Se a gente fica sabendo que tem alguém desmatand, a gente dá em cima mesmo, porque se for depender da policia florestal, logo isto aqui tudo se acaba!".

\subsubsection{Saneamento básico}

Para o conjunto da população entrevistada, o problema de saneamento básico na Cratera resume-se à questão do esgotamento sanitário, e concretiza-se em um dos problemas mais graves existentes na área.

A falta de esgotamento sanitário é um tema que aparece de forma recorrente nas diversas falas. Embora a referência ao problema faça parte do discurso dos entrevistados em geral, aqueles cujas residências situam-se nas margens ou nas proximidades do Ribeirão Vermelho são que mais enfatizam a falta de rede coletora de esgoto, uma vez que, em épocas de muita chuva, suas casas são invadidas pelas águas contaminadas pelos dejetos lançadas a céu aberto. 
"Um dos grandes problemas aqui da Cratera é a falta de uma rede de esgotos. A maioria dos esgotos é jogado diretamente nos córregos da região, ou lançadas diretamente na rua a céu aberto. Então, quando chove forte, ele volta".
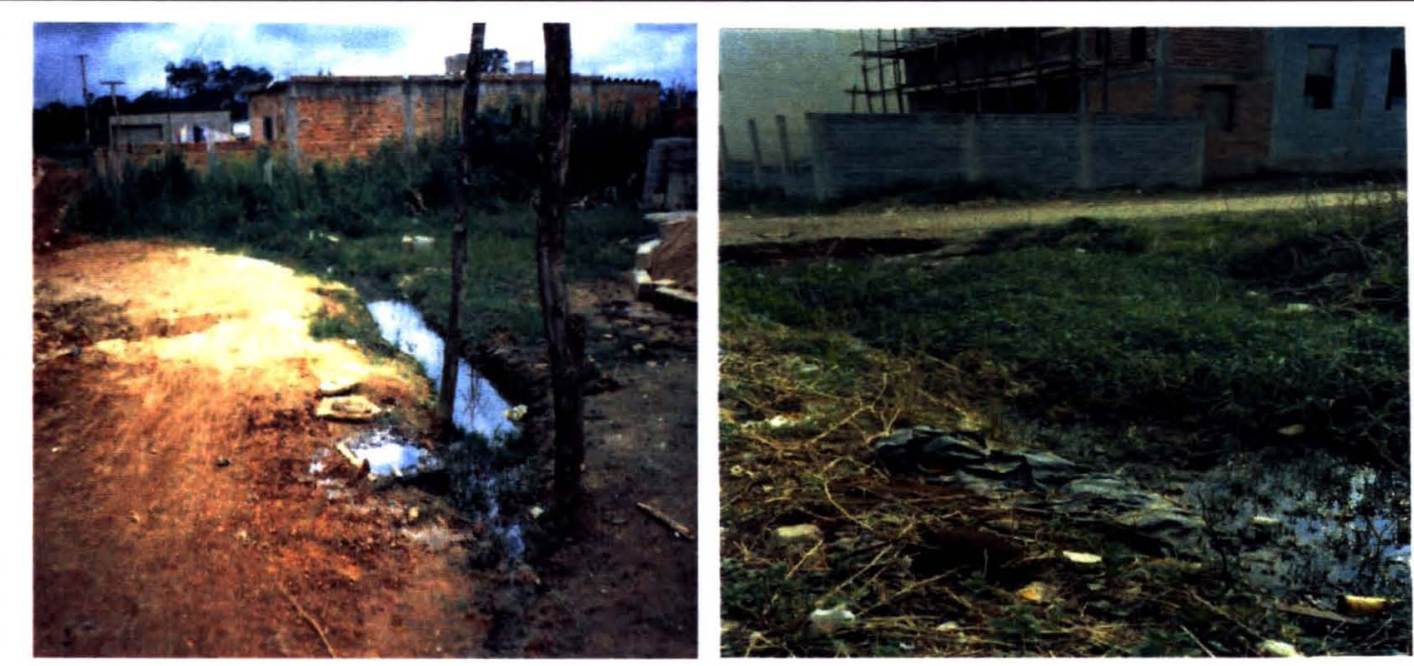

Figura 31 - Lançamento de esgoto à céu aberto dentro do condomínio Vargem Grande.

Os altos custos de infra-estrutura sanitária desafiam os governos municipais, estaduais e federais, uma vez que é impossível ignorar os prejuízos que a falta de saneamento acarreta para a saúde e para o meio ambiente.

De acordo com HOGAN (1995), a falta de saneamento é um problema ambiental colocado em segundo plano na agenda ambiental global. Nos países ricos esse problema foi resolvido desde o início do século $\mathrm{XX}$, representando um dos principais fatores do declínio das taxas de mortalidade e morbidade desses países. Porém, nos países pobres ou em desenvolvimento, a falta de saneamento é um dos mais graves problemas enfrentados pelas populações urbanas, o que se traduz em altos índices de mortalidade e de morbidades por veiculação hídrica, segundo dados da OPAS - Organização Pan-americana da Saúde (OPAS 1999). 


\subsubsection{Pavimentação}

Outro grande problema citado em todas as entrevistas refere-se à falta de pavimentação da área, principalmente aquela localizada bem no centro da Cratera. Mesmo pessoas entrevistadas que não residiam na área central da Cratera citaram a falta de pavimentação como um problema ambiental da região, uma vez que é no centro da Cratera que se localizam as escolas, o posto de saúde e o centro comercial local.

Enquanto problema ambiental urbano, a pavimentação pode ser inserida na questão da impermeabilização do solo, gerada pelo modelo de urbanização que pautou a ocupação "desordenada" e o adensamento populacional intenso das cidades brasileiras, representando um grave problema ambiental. Há que se atentar para esse fato na área da Cratera da Colônia, uma vez que se constitui em uma das reivindicações mais enfáticas e antigas da população.

A perda da cobertura vegetal e a diminuição de espécies arbóreas ocasionam a redução do percentual de áreas verdes, com relação à superfície total do território de uma cidade ou de um lugar. O resultado é um maior volume de partículas em suspensão na atmosfera, com aumento da poluição ambiental, perda da qualidade do ar, desconforto e, conseqüentemente, declínio da saúde ambiental e da qualidade de vida. Embora a região da Cratera não padeça do problema com a poluição atmosférica, argumento este que poderia justificar a pavimentação total do loteamento, caberia um estudo mais detalhado com relações a outras implicações ambientais, se a reivindicação dos moradores entrar na pauta da Prefeitura Municipal de São Paulo.

Uma dessas implicações estaria relacionada ao fato de que uma das conseqüências da impermeabilização do solo consiste no assoreamento dos mananciais, em decorrência da correlação que pode ser estabelecida entre a redução da cobertura vegetal de uma área ou região, e o maior carreamento de sedimentos para as fontes hídricas. A impermeabilização asfáltica do solo, tal como se verifica no modelo de urbanização das cidades brasileiras, também está associada à erosão do solo, devido à eliminação da permeabilidade hídrica dos solos. 
Com relação à falta de pavimentação, problema colocado pelos entrevistados, duas questões paradoxais estão associadas à impermeabilização do solo. De um lado, os processos construtivos urbanos, na medida em que implicam em uma redução drástica da capacidade de drenagem natural das precipitações pluviais, podem acarretar enchentes com graves prejuízos sociais à população. Por outro lado, a própria população é levada a requerer, como atributo da qualidade de vida, a pavimentação de superfícies cada vez mais extensas do solo urbano, para circulação de pedestres e veículos em condições mais confortáveis e consideradas saudáveis, a exemplo do que é requerido pela população da Cratera da Colônia.

Portanto, as questões acima discutidas devem ser consideradas de uma forma sistêmica e abrangente no atendimento às demandas da população, exteriorizadas como necessidade de pavimentação, como foi o caso da Cratera da Colônia.

\subsubsection{Lixo}

O lixo talvez seja um dos mais "desagradáveis" problemas percebidos no cotidiano pelos entrevistados da Cratera da Colônia. Segundo JACOBI (1995), as percepções referentes ao lixo estão centradas, principalmente nos constrangimentos e desconfortos que provocam na rotina e nas atividades do cotidiano doméstico. Para GÜNTHER \& RIBEIRO (2003), o acúmulo de lixo, de uma maneira geral, só recebe a atenção devida tanto do poder público como da sociedade civil em geral, quando se torna visível ou quando causa um transtorno concreto, como a liberação de odor desagradável ou a proliferação de vetores.

O lixo constitui-se em um resultado da ação humana sobre o ambiente. Em todas as atividades da vida os seres humanos produzem resíduos, e qualquer material é passível de se tornar resíduo, desde que não seja mais considerado dotado de valor suficiente para ser conservado.

O processo de urbanização, assim como o aumento da sociedade de consumo, vem engendrando uma crescente produção de resíduos sólidos, que resultam em um problema ambiental de grande magnitude, uma vez que as soluções para a deposição 
desses resíduos ainda são bastantes discutiveis e as alternativas para a redução da geração de resíduos ainda são escassas.

Segundo PHILIPPI JR (1982), os primeiros processos de manipulação de resíduos sólidos visavam afastar para bem longe o que sobrasse das atividades humanas, o que talvez possa explicar a prática do lançamento dos resíduos sólidos em terrenos baldios, ao ar livre e em cursos d'água.

A prática do despejo de lixo em áreas inadequadas, como "lixões", córregos, terrenos desocupados e outros locais, constitui-se em grave problema ambiental, uma vez que os dejetos podem causar poluição do solo e dos mananciais, por meio da degradação da matéria orgânica e da geração de chorume, assoreamento de rios e represas, além de transformar essas áreas em locais propícios ao desenvolvimento de insetos e roedores - vetores de doença - que representam riscos à saúde da população local (GÜNTHER \& RIBEIRO 2003).

Na Cratera da Colônia, de acordo com os relatos de vários entrevistados/as, a questão do lixo não vem recebendo atenção devida seja por parte da Prefeitura Municipal, que não vem cumprindo os seus deveres seja por parte dos moradores "que não possuem uma conscientização" sobre a importância da questão referente ao tema dos resíduos sólidos.

“O lixeiro aqui só passa duas vezes por semana e a gente não tem onde pôr o lixo, e a cidade têm muitos cachorros. Se a gente deixar dentro de casa, é aquele fedor. Se deixar no quintal, os cachorros fazem a festa!"

“Tem lugares aqui no Vargem Grande que o lixeiro não consegue entrar, então é preciso levar o lixo até a rua principal para que o lixo seja coletado. Mas acontece que muitas pessoas colocam o lixo após o lixeiro ter passado, e aí o lixo fica lá no meio da rua até o dia que o lixeiro passe novamente. Então é isso, o próprio povo não tem educação, é o próprio morador que faz a sujeira!" 
"A gente cansa de falar na rádio sobre a necessidade de se tomar mais cuidado com o lixo, de somente colocar o lixo nos dias em que o lixeiro passe, mas não adianta falar que o povo não liga, porque falta uma conscientização do próprio morador, que ele também deve ser responsável pelo cuidado com o lugar que mora, de plantar uma árvore na frente da casa, de cuidar de colocar o lixo somente nos dias em que o lixeiro passe, as pessoas precisam ter mais consciência!"

Cabe destacar que a ACHAVE vem organizando junto, à população "mutirões de cata-bagulho" e limpeza nos córregos da região, ações estas, consideradas pelos lideres da Associação, como instrumentos de conscientização sobre a problemática referente aos resíduos sólidos. O que se percebe, porém, é que aquilo que eles denominam de uma maior conscientização se refere, apenas ao controle da questão. No que tange a uma educação mais reflexiva, voltada para a adoção de práticas e estratégias de minimização de resíduos, nem sequer é abordada.

Diversas pessoas relataram, ainda, que uma das soluções possíveis para a questão consiste em um projeto de coleta seletiva do lixo, que vem sendo implantado na região, o que vem gerando muitas expectativas na população em geral. Cabe destacar que, na visão da maioria dos entrevistados e entrevistadas, a coleta seletiva e a reciclagem se constituem numa possivel geração de renda, e também em um ambiente mais limpo na Cratera.

Realmente, grande parte das discussões engendradas acerca dos resíduos sólidos, aponta que uma gestão competente e adequada desses resíduos pode transformá-los, de ameaça ambiental, em oportunidades de renda e de emprego para populações municipais (HOGAN 1995; GÜNTHER \& RIBEIRO 2003).

Contudo, somente a reciclagem, que em muitas vezes é entendida como sinônimo de coleta de materiais, não resolveria o problema, fazendo-se necessário o envolvimento de todos no processo de gestão dos resíduos, tanto da população quanto do poder público, desde a minimização dos residuos até a deposição dos 
mesmos, sendo que a coleta dos materiais recicláveis é apenas uma parte do processo (GÜNTHER \& RIBEIRO 2003).

Já o técnico da prefeitura que vêm assessorando o projeto, por sua vez, enfatizou que é sozinho para trabalhar com toda a área da APA, o que dificulta bastante o trabalho e o impede de fazer um acompanhamento mais amiúde da implantação do projeto, e de promover uma discussão mais profunda sobre a temática dos residuos sólidos. Este mesmo técnico enfatiza, também, que é notável a falta compromisso e união dos moradores da Cratera na continuidade do trabalho.

A questão do lixo vem demonstrando ser bastante emblemático da questão ambiental. De acordo com HOGAN (1995), não é só um símbolo, porém trata-se da própria materialização do desperdício das sociedades contemporâneas, de onde se origina toda uma cadeia de problemas ambientais, tais como desmatamentos, aumento do aquecimento global, mais poluição, mas também é emblemático na sua solução.

“Quando a sociedade passar a produzir menos lixo, a separar o lixo antes de colocá-lo na rua, vê-lo reutilizado, reciclado ou compostado, os efeitos pedagógicos serão incalculáveis". (HOGAN 1995, p. 19).

\subsection{Formas de enfrentamento dos problemas ambientais: soluções e responsabilidade}

Aproveito pra falar Ao governo brasileiro Que se implantar turismo $\mathrm{Na}$ Cratera bem ligeiro Colônia vai ser sucesso Aqui e no mundo inteiro
Um turismo pioneiro Que ajude a população Fomente muita pesquisa Pras escolas da nação Que aquilo é ciência viva Cultura e educação

Valdeck de Garanhuns

Uma das preocupações que nortearam o presente trabalho foi captar as percepções da comunidade da Cratera da Colônia sobre os principais problemas 
ambientais, assim como as soluções encontradas por essa população para enfrentar os problemas percebidos e identificar quem seriam os responsáveis por essas soluções.

A maioria absoluta dos entrevistados afirmou que as soluções para a questão ambiental passa pela resolução da questão do desemprego, uma vez que esses dois aspectos estão intimamente relacionados.

Como uma das possíveis soluções, os entrevistados e entrevistadas, especialmente aqueles que participam dos movimentos associativos, mencionaram programas de estímulo à criação de novos projetos de geração de renda, voltados especialmente para as os mais jovens e para as mulheres. Dentre essas possíveis atividades citam a produção de um viveiro de bromélias, que poderiam ser vendidas para floriculturas na cidade; projetos no desenvolvimento da apicultura; e a capacitação de jovens da comunidade para serem agentes ambientais na área da APA, visto que a área possui um importante potencial turístico. Também foi lembrado o incentivo a projetos de geração de renda, tais como o desenvolvimento de atividades agrícolas diversificadas, como o cultivo de cogumelos e de hortaliças diferenciadas; e cursos de computação, voltados especificamente para os jovens da Cratera.

Os entrevistados e as entrevistadas mencionaram ainda a criação e a ampliação dos espaços públicos que permitissem a multiplicidade de atividades, tais como lazer, cultura, comércio, entre outras.

A criação de áreas para a prática de esportes na região, tais como "a construção de uma mini-vila olímpica", a construção de uma "pista para skate", a construção de um mirante, aparecem como medidas importantes para o lazer.

Apresentou-se também a necessidade de mudanças de hábitos e práticas no cotidiano das pessoas, o que se conseguiria através do envolvimento tanto da comunidade quanto do poder público em campanhas ambientais e institucionais, tais como: limpar as ruas e as praças; não estragar os jardins; mobilizar a comunidade para a implantação de áreas de lazer e de áreas verdes; recuperar os rios da região; realizar campanha comunitária de limpeza dos quintais. 
Os entrevistados enfatizaram ainda, como soluções para a questão ambiental, a necessidade de políticas públicas que favoreçam a resolução dos problemas elencados, assim como a necessidade de confiabilidade nos órgãos públicos e na ação dos grupos da comunidade.

O asfaltamento e a iluminação de vias públicas e a conservação do que já existia seriam uma condições básicas para a solução de grande parte dos problemas ambientais, segundo o ponto de vista dos entrevistados da Cratera da Colônia.

Por unanimidade, o conjunto das pessoas entrevistadas enfatizou a ação governamental como imperativo para a solução dos problemas: haveria necessidade de um papel indutivo do Poder Executivo e do Poder Legislativo Municipal no tocante a uma política de geração de renda.

Quanto às responsabilidades pelos problemas da Cratera da Colônia, o conjunto dos entrevistados enfatizou, unanimemente, a ação governamental, ou a não-ação do governo e a falta do estabelecimento de políticas públicas, como principal agentes intervenientes para o agravamento do problema.

“Veja só, essa cidade nunca possuiu uma política habitacional que atendesse a população mais carente, e dá nisso: a população não tendo como ter acesso à casa própria vai procurar a satisfação de seus desejos na compra de lotes mais baratos, que estão justamente nessas áreas mais desvalorizadas, como é o caso das áreas de mananciais".

"Olha, pra falar a verdade, eu acho que esses políticos estão enterrando as nossas cidades em muitas dívidas e com muita corrupção. Eu acho que o governo... o Geraldo, a Marta, né? Eles que deviriam olhar mais pra esses bairros pobres".

Embora a maioria dos entrevistados e entrevistadas citasse como principal agente interveniente a ação governamental, muitas enfatizaram também a ação comunitária como co-responsável. 
“Olha, em termos da responsabilidade seria do prefeito mais o conjunto da população. A população devia ter um conhecimento melhor, pra saber preservar mais as coisas. Bom, eu acho isso aí... eu acho que não é só dever do prefeito como da população... Tem que ser unido, tem que procurar ver vai ser bom pra todo mundo... vamos fazer ... vamos trabalhar todos juntos ...".

“Escuta aqui, não é só dela (a prefeita) a responsabilidade, mas é principalmente dela... porque tem prefeito, eu sei porque eu vejo na televisão que tem prefeito que é criativo. Cria alguma coisa com a comunidade, com o povo, mas para nós da Cratera as coisas sempre foram muito dificeis. Se existe alguma coisa por aqui é porque nós, o povo, construímos, porque se a gente fosse esperar pelo poder público isso aqui não existiria!". 


\section{CAPÍTULO 6}

ENTRE O LOCAL E O GLOBAL: O ESPAÇO DA CONSTRUÇÃO DA CIDADANIA 


\subsection{A emergência da dimensão comunitária e cotidiana e as transformações no "mundo da vida" de homens e mulheres}

Reportando-se à história da humanidade, os estudos indicam que, até o recente advento do capitalismo, enquanto sistema político e econômico gerador de uma sociedade atomizada e desarticulada, os homens e mulheres sempre viveram em comunidade. Segundo ORTIZ (1995), o cidadão contemporâneo acostumou a considerar como positivo tudo o que vai do pequeno para o grande: assim o clã, a tribo, a aldeia, são coisas de um passado longínquo, enquanto que a modernidade trouxe o conceito de nação, de global.

Essa discussão sobre o global e o local é bastante oportuna à medida que permite ao pesquisador pensar sobre os problemas ambientais locais, e sobre o modo como estes se tornam reconhecidos como relevantes no cenário mundial, por meio do movimento ambientalista globalizado, como é o caso dos riscos ambientais urbanos. Esse movimento de "tornar-se global", mas que se expressa de forma particular em países, regiões e cidades foi colocado, neste trabalho a fim de abordar as possíveis conexões e as múltiplas redes que existem entre os vários atores e realidades materiais envolvidos na construção social dos riscos, associados à degradação ambiental.

A temática do saber local, do poder local ou do desenvolvimento local, como já enfatizado na primeira parte da tese, tem sido alvo do questionamento no âmbito das diversas áreas do conhecimento e, especialmente, dentro do campo da economia política. DOWBOR $(1995,1999)$ relaciona o tema do desenvolvimento local ao conceito de espaço, sobretudo, aquele em que acontece a reprodução social ${ }^{17}$, no processo de desenvolvimento.

Para DOWBOR (1999) a simples reprodução do capital ou reprodução econômica já não é suficientemente abrangente para refletir os problemas

\footnotetext{
17 Reprodução social se contrapõe à reprodução do capital. Reprodução do capital refere-se, essencialmente, ao processo de crescimento econômico centrado nas atividades produtivas. Reprodução social é mais ampla: define tanto a produção como os serviços sociais e as diversas atividades de gestão do desenvolvimento, como planejamento, segurança, entre outros (DOWBOR, 1999).
} 
decorrentes da globalização, da constituição dos blocos econômicos e políticos, inclusive para entender a própria reprodução do capital.

Para tanto, é importante resgatar o pensamento que este autor traz ao cenário das discussões, e que já foi enfatizado na primeira parte desta tese, que é o conceito de reordenamento dos espaços, uma vez que conceitos como "globalização", na visão deste, imprimem uma visão simplificada de abertura e unificação dos espaços da reprodução social. Para DOWBOR $(1995,1999)$ o que vem ocorrendo é uma nova hierarquização dos espaços, de acordo com diferentes atividades, envolvendo tanto a globalização como a formação de blocos, enfraquecendo dessa maneira o conceito de Estado-Nação e propiciando o surgimento de espaços subnacionais fracionados.

" $E$ melhor ser cidadão local ou cidadão do mundo?" Pergunta-se o economista . Em resposta, o próprio perguntador enfatiza: "a pergunta não tem sentido na medida em que a cidadania deve ser exercida em todos os níveis diversos de espaços articulados. Transferir a cidadania para niveis cada vez mais amplos e cada vez mais distantes do cidadão significa transferir um poder significativo para mega-estrutura multinacionais, enquanto se dilui a cidadania no anonimato". (DOWBOR 1995).

Assim como a mundialização, ou segundo outros, a globalização, é uma realidade, percebe-se também, na época atual, um movimento de localização, uma vez que cada lugar traz em si o universo como um todo. Como bem diz MORIN (1995) "fazemos parte de um holograma".

Segundo SANTOS M (1997), impõe-se a necessidade de revisitar o lugar no mundo atual, conhecer seu cotidiano, a fim de encontrar novos significados. Globalização e fragmentação; globalização e localização, fazem parte de uma realidade tensa, instável, na qual a dialética se refaz com freqüência e com muita velocidade. Todos os lugares são virtualmente mundiais, porém cada lugar, imerso numa comunhão com o mundo, traz em si uma diversidade própria que o faz diferente de todos os outros (SANTOS M 1997).

Inspirando-se em Marx, pode-se constatar que não existem problemas ambientais desvinculados de formações sociais, econômicas e culturais, isto é, os 
sistemas ambientais não se desenvolvem e nem funcionam em um vácuo sociocultural; a Cratera da Colônia, nesse sentido, traz em si, guardadas as devidas proporções, as contradições e problemas dos grandes centros, porém de uma maneira singular.

Apoiando-se também em autores como SANTOS BS (1995); SANTOS M (1997); IANNI (1992, 1996); GIDDENS (1991, 1995); DOWBOR (1995, 1999) que, em seus estudos constatam que a presente fase da globalização apresenta, em seu processo, resultados bastante negativos ao desenvolvimento humano, como acentuadas disparidades regionais, desigualdades sociais e exclusões de várias ordens, pode-se considerar que a Cratera da Colônia traz em seu cotidiano, as contradições e as vicissitudes do processo de globalização.

A lógica imposta pelo desenvolvimento econômico mundial vem repercutindo, de forma sistemática e impactante, sobre os ecossistemas Isto exemplifica bem o porquê do mote do movimento ambientalista mundial "pensar globalmente e agir localmente", e vice-versa. Acontecimentos que, a princípio, parecem muito localizados e sem importância, na maioria das vezes trazem implicações de repercussões globais, tanto em níveis econômicos, quanto políticos, sociais, culturais e ambientais.

Olhando para o local onde foi desenvolvida esta tese, pode-se afirmar que a desarticulação de projetos, no âmbito da comunidade, se faz sentir. Embora todos possuam os mesmos objetivos - melhoria da qualidade de vida, desenvolvimento de projetos de geração de renda, projetos de atendimento a crianças em situação de exclusão - não há uma articulação entre os diversos setores organizados da população. Na prática, cada um desses setores desenvolve um trabalho isolado, cujos resultados não atingem as expectativas da população local. É nítida a fragilidade das experiências experimentadas pelos diversos movimentos da Cratera da Colônia, que mostram as dificuldades de assimilar um modelo mais participativo e intersetorial.

Apesar dos problemas observados na construção de um projeto de desenvolvimento voltado para a Cratera da Colônia, percebe-se que há condições políticas favoráveis para o estabelecimento de fóruns de discussão e construção de 
projetos conjuntos entre a Associação de Moradores, o Programa Saúde da Família, as escolas municipal e estadual e com instituições do Terceiro Setor. Há um desejo de participar, uma força impulsionadora mas, na prática, não há nada concretizado.

Cabe também à população, individualmente e também por meio de suas organizações de representação, inserir-se nas instâncias de atuação do Estado, de forma a subsidiar a adoção de práticas participativas para implantar programas, projetos e atividades ambientais, os quais representam, sem dúvida, atendimentos às necessidades sociais básicas e aos direitos sociais de cidadania, estabelecidos constitucionalmente.

Como já destacado, a crise socioambiental no Século XXI, no Brasil e no mundo, implica no reconhecimento de uma crise mais ampla, social, política, econômica, cultural e ambiental. A gravidade desta crise evidencia-se na constatação de que grande parte dos problemas detectados envolve a forma pela qual as pessoas concebem a questão socioambiental - quase sempre como algo desconectado do ser humano, como algo externo ao homem. Portanto, para a superação de tal crise, faz-se necessária uma transformação dessa concepção, de forma que a questão ambiental passe a ser entendida como resultante das condições de vida da população, e em cuja trajetória de mudança os aspectos econômicos, políticos, culturais, ambientais sejam incorporados ao processo.

E é justamente na busca dessas transformações que profissionais da área ambiental, da área da saúde, enfim, de todas as áreas devem se propor a agir nos diferentes espaços do cotidiano, pois é na "cotidianidade" que o sujeito atua e exerce suas atividades, estabelecendo relações as mais variadas possíveis, deparando-se com escolhas e oportunidades de reflexão e de transformação dessa realidade social a qual está inserida.

De acordo com HELLER (1970) é nessa cotidianidade que se traduzem as mais diversificadas experiências no trabalho, nas relações familiares, na religião, nos lazeres, entre outras. Dentre essa infinidade de experiências significativas, com as quais os sujeitos se deparam, estão as que manifestam nas lutas por uma vida 
cotidiana mais digna, mais justa e que refletem a resistência destes a uma situação dominadora

$\mathrm{Na}$ história da humanidade, homens e mulheres no seu devir de produzir e reproduzir a vida, para a sobrevivência ou para a conservação, tanto individual quanto coletiva apropriam-se de recursos "naturais", modificando e transformando o ambiente em que vivem, e transformando também a si próprios, cada um a seu modo, cada sociedade a sua maneira.

Morar, alimentar-se, vestir-se, trabalhar são preocupações de que se ocupam homens e mulheres de quaisquer partes do mundo, independentemente de seus sistemas econômicos, sociais, étnicos ou religiosos. De acordo com FREIRE (1978), as relações que o ser humano trava no mundo (pessoais, impessoais, corpóreos e incorpóreos) são o que o distingue dos outros animais. Para ele, o mundo é uma realidade concreta, objetiva, enquanto o ser humano possui raizes espaço-temporais: não está no mundo, mas com o mundo. É um ser da práxis. Práxis entendida como uma ação e reflexão dos homens e mulheres sobre o mundo, com o objetivo de transformá-lo.

São nas experiências contestadoras e em outras, não tão contestadoras, mas, travestidas de um caráter de resistência, que a população vem se engajando na luta pela emancipação, pela ampliação do acesso ao espaço público, ao poder político ou a melhores condições de vida, experiências estas que têm contribuído para a sobrevivência ou para o aparecimento de movimentos populares, de associativismo civil, ou dos novos movimentos sociais.

Considerados como respostas às estruturas dominantes da sociedade, esses movimentos populares e, em particular, o movimento de luta por moradia na Cratera da Colônia, vêm gerando experiências, aprendizados e revelando-se instrumentos capazes de propiciar a seus participantes, embora de uma forma lenta, a elaboração de uma visão mais crítica dos processos sociais, permitindo a passagem de uma visão fragmentada de mundo para uma visão mais abrangente, o que pode representar o início ou o crescimento de uma consciência crítica, conforme já evidenciado em estudos anteriores (PALOS 2000). 
Como bem coloca EVERS (1984), o grande potencial desses movimentos sociais não diz respeito ao poder mas, principalmente, à renovação de padrões socioculturais e sociopsiquícos do cotidiano, penetrando na microestrutura da sociedade.

GOHN (1997), em uma investigação acerca dos movimentos sociais no Brasil, destacou a importância do caráter educativo presente nos movimentos populares que, por meio dos processos vivenciados, vêm gerando profundas e importantes aprendizagens para os seus participantes: a aprendizagem gerada com a experiência cotidiana com representantes da sociedade política formal; a aprendizagem gerada pelo exercício repetido de ações cotidianas impostas pela burocracia estatal; a aprendizagem das diferenças existentes na realidade social, a partir da percepção das distinções nos tratamentos que os diferentes grupos sociais recebem do poder público ou do contato com outros movimentos sociais; a aprendizagem gerada pelo contato com grupos advindos da universidade e de segmentos da mídia. Todas essas aprendizagens foram vivenciadas pelos dirigentes da ACHAVE, e também, por grande parte dos participantes nesses movimentos.

A análise da história dos integrantes do associativismo civil, estabelecido na Cratera da Colônia pelos membros da ACHAVE, mostrou que, inicialmente, antes de se engajarem no movimento, percebiam a realidade como algo acabado e imutável, uma vez que as circunstâncias da vida não lhes forneciam elementos para que pudessem apreendê-la de forma mais abrangente .

"Antes de participar da associação eu era uma pessoa muito diferente, vivia para cuidar da casa, dos filhos, do marido, mas quando viemos morar aqui na Cratera tudo mudou, comecei a participar do movimento, pois não tinhamos para onde correr, empregamos todo o nosso dinheirinho aqui, no sonho de ter uma casa própria e não pagar mais aluguel. (....) No inicio comecei a cozinhar para aqueles que começaram a construir a escola. Isto foi um tempão, depois comecei a trabalhar diretamente na associação. Foi lá que eu conheci um montão de 
gente importante! Quantas vezes eu não sentava com o governador, com o prefeito para discutir assuntos aqui do Vargem Grande! Nunca imaginei na minha vida que isto pudesse acontecer".

Porém, no desenrolar de suas vidas, com a participação no movimento da construção da moradia, na construção da escola, nas lutas pelo abastecimento de água, dentre outras, essa fragmentação de suas consciências começou a se desfazer. Isso aumentou justamente a partir do momento em que começaram a se deparar com realidades diferentes, trazidas pelas outras pessoas do movimento, e a partir do confronto com outras visões de mundo que os levaram a refletir sobre suas condições de vida e a acreditar nas possibilidades de mudanças (SAWAIA 1987; ZIONI 1994; PALOS 2000).

“Você não tem nem idéia o quanto mudou a minha vida depois que entrei para a associação. Em primeiro lugar, mudou com relação ao meu entendimento da questão ambiental, pois antes de me meter nesse movimento não tinha a menor idéia do que era ecologia. Em segundo, mudou a minha vida enquanto pessoa. Antes jamais que eu conseguiria falar com uma pessoa como estou falando agora com você. Agora não, agora eu converso com qualquer pessoa e não tenho vergonha, pois sei o quanto isto é importante, sair, conversar, conhecer coisas novas. No início o meu marido não gostava muito, pois eu ficava muito tempo fora de casa. Depois ele foi entendendo e hoje ele até ajuda nas tarefas domésticas! Para mim, entrar na associação trouxe grandes mudanças, mudou a minha vida, a minha cabeça, a minha relação com meu marido, com meus filhos".

As atividades desenvolvidas na Associação ACHAVE têm possibilitado, a mulheres e homens, um confronto entre o significado social, assimilado em seus processos de socialização, e a realidade que vivenciaram. Ao se depararem com essas contradições, estão sendo impulsionadas a refletir e a reinterpretar esses significados, 
o que tem permitido a emergência de novas idéias, novos valores, pensamentos, sentimentos e, conseqüentemente, novos comportamentos.

\subsection{O papel da educação ambiental como busca de solução para os problemas socioambientais na Cratera da Colônia}

O tema da educação constituiu-se como um ponto forte em termos de possíveis soluções, tanto nas falas dos entrevistados e das entrevistadas da comunidade, como dos líderes comunitários e técnicos do poder público e dos movimentos ambientalistas.

Desenvolver campanhas educativas, tanto nas escolas quanto nos diversos grupos sociais, para informar e formar as pessoas no tocante a uma consciência dos problemas ambientais e saúde na Cratera da Colônia, é uma tônica recorrente em todas as entrevistas.

"A população deve ser conscientizada para a importância da participação na resolução dos problemas ambientais, assim como também o poder público, pois só em conjunto é que conseguiremos algum resultado satisfatório".

"Na parte assim do meio ambiente, eu não sei, eu estudei pouco, eu não sei muita coisa, mas uma coisa que eu acho é que deveria ter uma pessoa para ajudar, para explicar para as pessoas aqui do Vargem Grande o que é o meio ambiente, porque muitas pessoas não sabem. Eu mesmo tô respondendo, mas sinceramente, eu não sei muito que é meio ambiente. Eu penso que devia ter um local pra fazer reunião e ter os dias pra explicar pras pessoas. Acho que isso seria muito bom...".

Comparando as pessoas entrevistadas da comunidade com outros interlocutores do poder público entrevistados, tais como técnicos da Prefeitura Municipal de São Paulo, da SABESP e ambientalistas que atuam na área, percebe-se 
uma diversidade de sentidos. Para cada um desses interlocutores, e conforme a posição que essa pessoa ocupa na questão mais ampla do controle ambiental, é possível delinear possíveis linhas de ação decorrentes dessa diversidade.

Muitas das representações, sentidos e significados, atribuídos à solução para a questão ambiental, organizam-se em torno de estratégias educativas, entendidas por vezes, como estratégias informativas e de controle por meio da gestão ambiental, e por meio de ações coletivas.

Quanto ao controle por meio de estratégias educativas, é necessário destacar os vários sentidos atribuídos à questão da educação, ora entendida como informação, ora como demonstração, ou ainda como educação formalizada. Parece existir uma certa idéia generalizada de que, por meio da educação como prescrição, a estratégia fundamental empregada na prevenção de agravos à saúde, é possível diminuir os impactos causados pela degradação ambiental. Educar, informar, formar são sentidos atribuídos a uma série de estratégias, que buscam dar sentido à tão aclamada educação ambiental.

Esta idéia é disseminada pelos meios de comunicação locais (Rádio Comunitária e panfletos distribuídos pela ACHAVE) e legitimada no discurso preventivo dos profissionais da saúde do PSF - Programa Saúde da Família local, no discurso dos técnicos da área ambiental que atuam na região, e no discurso de promoção dos cuidados no manejo e na gestão ambiental, difundido pela SABESP.

Na vertente tradicional da educação ambiental e na educação em saúde, a educação tem sido entendida como coadjuvante no cuidado à saúde e na recuperação da degradação ambiental, proporcionando informação e sugerindo maneiras saudáveis de viver, para indivíduos, famílias e grupos, por meio da prevenção de doenças e pela promoção da saúde. Sob este enfoque, parece que a educação ambiental é uma prática sempre necessária e importante para aqueles que militam na área de prevenção, no entanto, esta estratégia parece apontar muito mais para a disciplina do indivíduo e para o controle das comunidades. A educação em saúde ou a educação ambiental, vistas nesta perspectiva, põem a ênfase no treinamento, ao propor comportamentos que, espera-se, sejam adotados, como é o caso dos 
moradores da Cratera no uso adequado do espaço e na postura de atitudes ambientalmente "corretas", intervindo, dessa maneira, nas práticas coletivas por meio da informação de condutas saudáveis.

Por meio da educação, os profissionais de saúde e da área ambiental veiculam elementos para a construção de sentidos sobre o que é esperado que seja uma pessoa saudável, e quais as posturas seguras para a preservação ambiental. Porém, na busca de educar populações, as estratégias de educação em saúde e ambiente tentam se deslocar de um discurso exclusivamente prescritivo, orientado principalmente à população adulta, mesclando-se com discursos que ensejam maior participação dos indivíduos e dos grupos, e ampliando a ação para grupos representados pelas crianças e pelos adolescentes.

A necessidade de morar justifica os esforços no controle da qualidade ambiental. Educar, entendido como responsabilizar, e regulamentar, no sentido de disciplinar o morador, são os elementos mais destacados no argumento de grande parte dos técnicos envolvidos em projetos de educação ambiental na região. A educação, definida como conscientização, ou melhor, como falta de consciência e de responsabilidade, surge como algo que deve ser adicionado, como componente, à pessoa que é objeto da ação educativa. No entanto, várias contradições são relatadas por técnicos que trabalham na área: embora pareça que grande parte da população esteja ciente das posturas ecologicamente corretas e da necessidade de preservação ambiental da Cratera, isso não parece ser suficiente para resolver a questão, na prática.

Nas entrevistas realizadas na Cratera, o tema educação foi referido todos os interlocutores entrevistados, e em todas as posições analisadas, como se pode observar nos discursos a seguir:

Para o técnico de educação ambiental da Prefeitura de São Paulo, a educação como modeladora de condutas, na questão ambiental, deve se orientar para a formação das futuras gerações, incidindo na educação formal nas escolas da região, por meio do ensino técnico dos jovens na Cratera que, futuramente, passarão a ser os guardiões do "meio ambiente". 
A educação, como estratégia de controle da degradação ambiental, também é abordada pelos profissionais de saúde do PSF, a partir do posicionamento de quem cuida e trata dos efeitos, na saúde humana, do ambiente deteriorado. Para a médica do PSF, o objetivo da educação, entendida, principalmente, como formação é "a redução de danos". Para essa entrevistada, a prevenção está intimamente relacionada às ações educativas como criação de oportunidades, especialmente para os jovens da Cratera, como alternativa às posturas nocivas. Baseada em seu referencial mais próximo, a médica do PSF propõe concentrar esforços no atendimento aos jovens em situação de risco da Cratera, por meio de palestras informativas, recurso didático tradicionalmente utilizado na área de educação em saúde, e por meio da intervenção nas escolas da região, para iniciar campanhas informativas, desde cedo, com crianças e jovens. Trata-se, de acordo como seu entendimento, da estratégia mais "prática e inteligente" para manter o risco sob controle, criando um suposto lugar seguro que poderia ser alcançado a partir da internalização de medidas de autoproteção.

Para o técnico da SABESP, a educação também é considerada uma estratégia fundamental para o controle da degradação ambiental: "A solução é a educação". Porém, a ênfase é dada à questão do desenvolvimento da conscientização, utilizando a escola e os meios massivos de comunicação como veículos para se alcançar esse objetivo. No entanto, ao ser questionado sobre o suposto papel da educação como ferramenta para resolver os problemas de saneamento da Cratera, este técnico salientou que o problema, nesse campo, é eminentemente técnico e político.

A SABESP tem desenvolvido diversas estratégias para contornar os problemas surgidos ao longo da ocupação na Cratera. No início da ocupação, foi a empresa de saneamento que instalou os reservatórios de água para a população, e posteriormente foi ela quem perfurou os poços artesianos.

No que se refere à função exercida na veiculação de sentidos, na mídia impressa na Cratera da Colônia, sobre o papel da educação no controle da questão ambiental, são publicados pela ACHAVE diversos panfletos com conteúdos sobre a problemática ambiental, além de informações divulgadas pela Rádio Comunitária de ampla circulação local, sobre esse tema, resgatando constantemente a necessidade da 
educação, entendida ora como capacitação, ora como informação, ora como prevenção, como solução aos problemas surgidos.

Para os dirigentes da ACHAVE, a compreensão da questão da educação ambiental também é entendida como prescrição, com ênfase na demonstração. $\mathrm{Na}$ concepção de seus dirigentes, essa educação viria a garantir a possibilidade de controle de uma maior degradação do ambiente na Cratera: o protagonista da ação educativa seria o morador, partindo do pressuposto de que ele apresenta um estado de ignorância, que requer estabelecer formas de comunicação adaptadas à compreensão de posturas mais saudáveis de modos de vida e de relação com o meio físico. Por outro lado, a ênfase na comunicação visual, e baseada na realidade local, é uma tônica sempre presente nas comunicações da ACHAVE.

Para um dos associados e que também participa do Conselho da APA, posicionando-se como membro do Conselho e guardião da qualidade ambiental da Cratera, a educação como construção de novas formas de sociabilidade e habitabilidade é aquela que possa determinar as formas mais adequadas de viver sem degradar o ambiente. Parece que a educação proferida pelo associado vai ao encontro do discurso dos técnicos de educação ambiental que atuam na Cratera, embora seja ele próprio o alvo da ação educativa.

Todavia, depreende-se do depoimento do informante uma postura de incorporação dos conceitos técnicos com as experiências práticas, o que se mostra bastante importante para a produção de conhecimentos alternativos, a partir de uma nova sociabilidade e habitabilidade, que possam ser incorporados e assimilados pela comunidade em geral.

Por outro lado, ao ser questionado sobre a eficácia de estratégias informativas tradicionalmente utilizadas, baseadas no uso de palestras, esse associado se contrapõe argumentando que esse tipo de métodos não é capaz de produzir mudanças. Ele assume um posicionamento crítico, questionando os interesses do poder público e dos políticos que atuam na região, no tocante à produção desses conhecimentos, sem qualquer sinal de responsabilidade com os efeitos causados pela ocupação clandestina do espaço urbano. Para esse líder comunitário, parece que os 
interesses políticos estão acima da necessidade de preservação dos mananciais da cidade de São Paulo e do meio ambiente como um todo.

O entrevistado declara a importância das ações de educação ambiental que vêm sendo implementadas pela ACHAVE e direcionadas à população da Cratera, ações educativas que fazem parte de um programa concebido a partir da implantação da APA - Capivari-Monos, com o objetivo de solucionar a problemática na região, mas que, na prática, não vem sendo implementada em toda a APA, por falta de compromisso por parte dos representantes do poder público.

Sua experiência como militante de larga trajetória em projetos locais, ambientais e por moradia, e nas diferentes instâncias de participação na gestão da questão ambiental, enriquecem seu posicionamento, relativizando posturas e argumentos que já fizeram parte das lutas ambientalistas por ele defendidas, ao longo de sua história de vida e de lutas na Cratera da Colônia.

Na discussão acerca da pertinência em que consistem as ações de educação ambiental implementadas na Cratera, cabe destacar que, dentre as estratégias preconizadas para o enfrentamento do problema, por parte de representações das organizações da sociedade civil, ou por outros setores da sociedade preocupados com a questão ambiental, a educação ambiental apresenta-se, com unanimidade, nas diversas propostas de encaminhamento de soluções para a crise ambiental, suscitando o debate sobre conscientização, cidadania, informação e participação, dentre outros.

A preocupação com a educação ambiental, como forma de minorar a problemática do ambiente, pode ser evidenciada em diferentes fóruns nos quais o assunto vem sendo discutido pela sociedade: encontros, debates, seminários, congressos científicos e outros. Mas que educação seria essa? Em que princípios filosóficos estaria fundamentada essa tão aclamada educação ambiental? Quem seriam os novos agentes sociais dessa educação? São algumas dessas indagações que instigam a reflexão e que se fazem presente nesta tese.

$\mathrm{Na}$ busca de possíveis respostas a esses questionamentos, desenvolve-se uma reflexão a partir do legado do pensamento de GRAMSCI (1966, 1979, 1984, 2001), cuja contribuição tem se mostrado bastante atual, não só no campo das ciências 
humanas, mas também na arte e na literatura. Tomando como pressuposto que a contribuição de Gramsci se constituiu, no interior da teoria marxista, como um dos pensamentos mais fecundos para o desenvolvimento de uma reflexão crítica sobre a sociedade capitalista, e na construção de uma sociedade socialista e democrática, uma pergunta que se faz necessário trazer para o debate é a seguinte: em que medida o pensamento teórico desse autor é capaz de contribuir para desvelar novas questões, ditadas pela ordem econômica, social e política que ora se apresenta, em tantos países, especialmente, no que se refere à crise socioambiental?

Esta reflexão remete-se, necessariamente, à crítica aos programas educacionais com enfoque comportamental e conservador, baseando-se principalmente em autores tradicionais como DÜRKHEIM (1955) e PARSONS (1964) que viam na educação o processo por meio do qual os indivíduos alcançariam não só o conhecimento e a instrução, mas também o altruísmo, a ordem, o equilíbrio e a harmonia, transmitidos de geração a geração com a finalidade de manter a estrutura e o funcionamento de uma dada sociedade. Programas como estes até hoje são largamente difundidos nos meios educacionais e na sociedade em geral, com conteúdos abstratos, desvinculados das condições concretas de vida dos cidadãos e das cidadãs, ou vinculados à idéia de que é possivel transformar a sociedade somente por meio da educação, a qual seria capaz de minimizar as diferenças econômicas e sociais entre os indivíduos, homogeneizando, assim, as relações sociais. No que se refere à educação ambiental, a maioria dos projetos educacionais referentes à temática não foge à regra, uma vez que, na maior parte das vezes, apresentam-se de forma desvinculada da realidade social e, via de regra, são impostos de maneira verticalizada (PALOS \& MENDES. 2001).

A educação ocorre mediando todas as relações sociais. Ninguém escapa da educação, enfatiza BRANDÃO, 1981. Não há, no entanto, um tipo único de educação, visto que ela sempre expressa uma doutrina pedagógica baseada em alguma filosofia de vida, em uma determinada concepção de ser humano e de sociedade. E nem há um único locus onde se exercite a educação. Ela está presente na escola, na igreja, na rua, no trabalho, no botequim da esquina, enfim, no cotidiano das pessoas de uma dada realidade social concreta (PALOS \& MENDES 2001). 
Faz-se importante enfatizar outro aspecto contraditório e fundamental da educação: se por um lado, ela tem uma função conservadora e mantenedora do status quo, por outro, carrega em si a função de transformar a sociedade, o que levou PAULO FREIRE (1978), inspirando-se no pensamento de Gramsci, a caracterizá-la como portadora de uma significação política na medida em que, no processo educacional, o indivíduo é habilitado a atuar no contexto social em que vive, não simplesmente reproduzindo as experiências anteriores, transmitidas pelas gerações que o antecederam, mas também somando a essas experiências sua análise e avaliação crítica, por meio das quais ele se torna capaz de organizar e reestruturar a sociedade.

Inspirando-se em Gramsci, parte-se do princípio que a educação é um ato político, na medida que transmite modelos que prevalecem em uma sociedade: modelos de vida, modelos de trabalho, de relacionamento e de condutas. Por serem modelos de grupos sociais influentes, esses modelos têm significação política, uma vez que a política exprime relações de força até entre ideais contraditórios e conflituosos. As idéias políticas sobre a sociedade, a justiça, a liberdade, a igualdade, por exemplo, impregnam os modelos. Nesse sentido, para esse autor, a educação é uma educação social, e deve ser uma reflexão permanente sobre modelos sociais e sobre a organização social; assim toda teoria da educação deve, necessariamente, ordenar-se a um projeto de sociedade (PALOS \& MENDES 2001).

GRAMSCI (1984) conceitua de "ideologia" as idéias hegemônicas que circulam na sociedade e que legitimam um conjunto de valores, os quais, em última instância, refletem as divisões e as lutas sociais e as relações de força da sociedade. Apesar de não ser um teórico explícito da educação, é Gramsci quem fornecerá os elementos para pensar uma teoria dialética da educação, na medida em que propõe uma revisão do conceito marxista de Estado. Se, em Marx, o Estado detinha a exclusividade da coerção e da violência, em Gramsci isso será subdividido em duas esferas: a sociedade politica, na qual se concentra o poder repressivo da classe dirigente (governo, tribunais, exército, polícia), e a sociedade civil, constituída pelas associações privadas (igrejas, escola, sindicatos, clubes, meios de comunicação), nas quais circulam as ideologias que funcionam como "cimento" da formação social, e 
por meio das quais a classe hegemônica procura impor à classe subalterna a sua concepção de mundo (BOBBIO, 1982).

Para GRAMSCI (1984), a sociedade civil expressa o momento da persuasão e do consenso que, juntamente com o momento da repressão e da violência (sociedade política), asseguram a manutenção da estrutura de poder (Estado). Na sociedade civil, essa dominação se expressa sob a forma de hegemonia. Essas perspectivas indicam a natureza contraditória da educação, explicitada por Gramsci, que é, ao mesmo tempo um instrumento estratégico de dominação nas mãos da classe dominante, e também um instrumento estratégico de libertação por parte da classe dominada, uma vez que, mediante seus intelectuais orgânicos, a classe dominada pode lançar no âmbito da sociedade civil sua contra-ideologia (PALOS \& MENDES 2001).

Gramsci será o pensador que atribuirá à escola e à educação o papel de uma dupla função estratégica: a de conservar e, ao mesmo tempo, minar as estruturas do modelo social e econômico. Para ele, "toda relação de hegemonia é necessariamente uma relação pedagógica", na medida em que a contra-ideologia pode apoderar-se da educação hegemônica, corroendo-a, destruindo-a e reorganizando-a numa nova educação, que por sua vez divulgará uma nova concepção de mundo (GRAMSCI 1979).

A partir do legado do pensamento de Gramsci, e buscando interpretar suas idéias no tocante ao papel da educação ambiental, considera-se a educação como um processo de intervenção nas condições sociais, um processo que tem um papel transformador, na qual os profissionais envolvidos tenham um papel políticopedagógico transformador, enfim, suas atividades não são neutras. Esses pressupostos orientam uma prática educativa que privilegia o diálogo, os encaminhamentos conjuntos na solução de problemas e, sobretudo, na construção de saber coletivo. $\mathrm{O}$ educando torna-se sujeito, exatamente pela possibilidade de criar e recriar o conhecimento e intervir na realidade, modificando-a (PALOS \& MENDES $2001)$.

Se se partir do pressuposto que a relação sociedade/natureza é algo concreto 
em cada momento histórico, entende-se que as soluções devam ser buscadas no relacionamento dos grupos que compõem a sociedade, o que envolve desde a organização da produção à apropriação de seus resultados, assim como as representações em geral sobre a natureza em seus aspectos social, político e cultural.

Inspirados ainda no legado de Gramsci reafirma-se, nesta tese, que a educação ambiental é uma educação política, que visa à construção da cidadania, e que deve ser exercida seguindo os mesmos princípios da educação em geral, fundamentada nas recentes contribuições do conhecimento científico, principalmente da filosofia da educação, que critica a educação tradicional, na qual se atribui grande valoração à transmissão de conhecimentos e quase nenhuma à bagagem social $\mathrm{e}$ cultural trazida pelo educando.

Nesse sentido, a educação ambiental não pode se pautar apenas na transmissão dos recentes conhecimentos da ecologia, mas sim colocar-se como uma estratégia de reflexão mais ampla, que conduza ao questionamento do modelo de sociedade em que se vive, na qual a idéia de desenvolvimento está pautada no aumento do consumo desenfreado, na produção para atender tal consumo, e no desperdício dos recursos naturais, desconsiderando a sustentabilidade das gerações atuais e futuras (REIGOTA, 1999).

Assim sendo, entende-se que a educação, da maneira aqui refletida, capaz de responder à complexidade da questão socioambiental, está pautada na participação de toda a sociedade, da elite acadêmica à população em geral, como agentes sociais transformadores de uma nova realidade, com a promoção de práticas inovadoras e pela disseminação de experiências alternativas, centradas no respeito às singularidades e às diferenças étnicas e culturais. A relação que se estabelece entre meio ambiente, educação e cidadania vem assumindo nesses tempos de globalização um papel cada vez mais importante e desafiador. Os processos sociais cada dia mais complexos, assim como os desequilíbrios e conseqüentes riscos ambientais que vêm se acentuando, demandam a emergência de novos conhecimentos, novos saberes baseados numa "nova aliança" entre os seres humanos e a natureza, em que a ética permeie todas as relações, sejam elas sociais, políticas ou econômicas, para que o conceito de sociedade sustentável saia do papel e se torne uma realidade. 


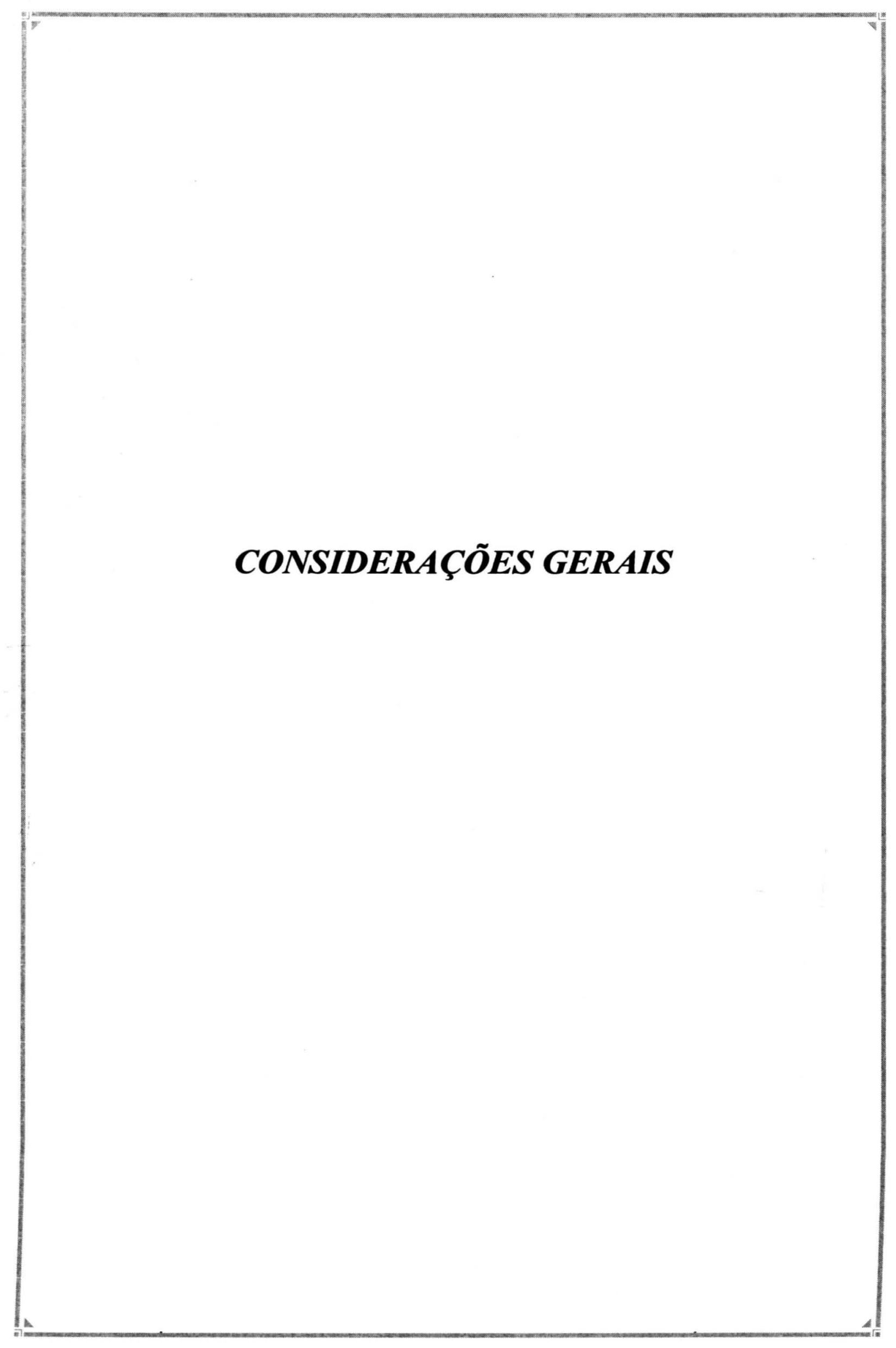


Consideraçòes Gerais

\section{A questão socioambiental na Cratera da Colônia: uma problemática em construção}

O intuito destas considerações gerais foi trazer algumas reflexões acerca das hipóteses levantadas nesta tese, e sobre os resultados encontrados.

Como foi demonstrada no decorrer da presente investigação, a degradação ambiental e os problemas de saúde pública vêm se convertendo em graves questões que a humanidade tem a enfrentar neste início de século. Cada vez mais se reconhecem os impactos nefastos das precárias condições de vida nas cidades e dos problemas ambientais à saúde e à qualidade de vida dos homens e mulheres das comunidades. Os problemas ambientais que afetam a saúde pública não são atuais, como parecem: desde a Antigüidade os problemas decorrentes da deterioração do meio ambiente se faziam presentes.

O debate, entretanto, é relativamente novo e se intensificou a partir dos anos 1970 em termos de preocupação e conscientização ambiental, interpretadas como reações diretas ao agravamento da situação que teve seu início, principalmente após a Segunda Guerra Mundial nas sociedades industriais ocidentais, alcançando seu ápice no final da década de 1960.

Todos se voltam para a relação meio ambiente e saúde: meio acadêmico comunidade científica, organizações-não-governamentais, setor público estatal. JACOBI (1996) alerta para o fato de que a relação meio ambiente e saúde está cada vez mais presente no cotidiano da população das cidades, especialmente nas grandes metrópoles, devido à dinâmica predatória da urbanização, à falta de responsabilidade e de compromisso do poder público e, muitas vezes, do próprio habitante urbano.

Foi visto também que crise ambiental não é uma situação que atinja exclusivamente os países pobres, ou em vias de desenvolvimento. Nos países do chamado "Primeiro Mundo", problemas ambientais decorrentes do modelo de desenvolvimento industrial e tecnológico adotado para a geração da riqueza e bemestar às chamadas sociedades desenvolvidas vêm se fazendo presentes. A chuva ácida, o efeito estufa, a destruição da camada de ozônio são graves exemplos de danos ambientais que decorrem dos altos níveis de poluentes jogados na atmosfera, 
além do lixo radiativo advindo das usinas nucleares, e da produção progressivamente crescente de resíduos sólidos.

Pode-se dizer que os problemas ambientais nas sociedades mais opulentas decorrem da manutenção de um estilo de vida baseado no consumismo e no desperdício, o que requer altos níveis de utilização de energia, água e de matériasprimas para sustentar os níveis elevados de produção de bens e produtos.

Porém, é nos países do Terceiro Mundo que os problemas ambientais ganham concretude, por estarem associados à pobreza extrema, tais como a forma como são explorados os recursos naturais; os modelos extensivos e irracionais de sua produção agrícola e pecuária; o aumento do processo de exclusão social, tanto nos centros urbanos quanto no meio rural.

As políticas macroeconômicas de corte neoliberal, aplicadas nos países pobres da América Latina, não têm proporcionado uma melhoria das condições de vida às populações da região, nem às condições ambientais globais; pelo contrário, milhões de seres humanos, em particular mulheres e crianças, estão sendo excluídos dos parcos benefícios deste modelo. $\mathrm{E}$ dentre as possiveis soluções, muitas alternativas apontam para a necessidade urgente e definitiva de superar a extrema pobreza e a exclusão social.

A situação encontrada na Cratera da Colônia corrobora todas essas afirmações. O grande conflito que pode ser destacado, a partir das observações de campo, é como atuar para a melhoria da qualidade de vida, para a obtenção de um ambiente saudável, se as condições concretas e objetivas de sobrevivência têm sido tão agravadas pelo modelo recente de desenvolvimento do país. Por outro lado, ficou demonstrado que, a despeito das dificuldades encontradas, a população vêm construindo formas criativas, e por que não dizer, sustentáveis, de lidar com a problemática construída em torno da questão socioambiental

O movimento de associativismo civil organizado para defesa dos interesses dos moradores locais, o processo de construção de uma habitabilidade digna, baseado em relações de solidariedade e de ajuda mútua, o processo de participação nos diversos fóruns de discussão e de implementação de políticas públicas para a região, 
as ações de educação ambiental implementadas, especialmente pela ACHAVE, a autoconstrução dos equipamentos sociais básicos para uma melhor qualidade de vida, a construção do "asfalto ecológico" são alguns exemplos, entre tantos, que comprovam que a população do Condomínio Vargem Grande vem se esforçando para a construção de um desenvolvimento social mais justo, economicamente viável e ambientalmente sustentável.

No tocante aos objetivos específicos desta tese, por meio das diversas vozes da população foi possível construir o panorama socioambiental da Cratera da Colônia com ênfase nas ações antrópicas e nas alterações socioambientais. Os dados obtidos indicaram que, embora a problemática referente à questão da água seja o assunto que mobiliza tanto o poder público quanto as organizações da sociedade civil que atuam na área, para grande parte da população os problemas mais referidos concentram-se no desemprego, na violência, na falta de esgotamento sanitário, nos desmatamentos constantes, nos problemas com alcoolismo e drogadição, sendo que estes últimos são questões de saúde que atingem, especialmente, as populações mais jovens. A falta de lazer e oportunidades educativas, especialmente para os mais jovens, são temas fortemente referidos e associados à degradação do lugar.

Conforme depoimentos da diretora do Programa Saúde da Familia (PSF) da região, os casos de diarréia, verminoses, hepatites tipo A e problemas de hipertensão foram os mais notificados no serviço de saúde local. Cabe destacar que morbidades como hepatite tipo $\mathrm{A}$, diarréias e verminoses estão diretamente relacionadas à contaminação ambiental e à falta de saneamento. De acordo com o PSF local, no início do ano 2004 foram notificados dois casos de leptospirose, cujas vítimas eram moradores de áreas periféricas da Cratera, conseqüentemente mais sujeitas às enchentes.

Segundo o relato dos entrevistados e entrevistadas, o desemprego é um fator determinante para os problemas socioambientais, uma vez que, gerando insegurança e ansiedade na população, pode desencadear distúrbios nervosos - na linguagem da comunidade - " a doença dos nervos", alcoolismo e hipertensão naqueles que não conseguem encontrar um modo de sustentar a família. 
No tocante à participação comunitária, embora todos os dispositivos constitucionais visem a garantir sua efetivação, o que se constata, ainda hoje, é que poucos são os profissionais que desenvolvem trabalhos integrados com as comunidades. A situação percebida na Cratera da Colônia é de um baixo índice de participação da comunidade nos assuntos relativos aos problemas socioambientais, devido ao desinteresse da população local em participar e à falta de espaços para a efetiva participação da população. Os poucos que o fazem encontram muita dificuldade em contatar as pessoas e, mais ainda, em desenvolver um verdadeiro trabalho participativo com elas, como foi relatado por uma das médicas do Programa Saúde da Família (PSF) local.

Partindo do pressuposto de que, no contexto atual, a promoção da saúde constitui-se como um conjunto de ações no ambiente social, político, educacional, econômico, cultural e nos serviços de saúde, com o fim de proporcionar condições saudáveis e prevenir o surgimento de doenças nos indivíduos e na coletividade, a intervenção dos profissionais que trabalham na área insere-se na mediação e na articulação entre diferentes atores sociais, como autoridades locais, organizações não-governamentais e população, entre outras.

Não se pode falar em promoção da saúde, nem em qualidade socioambiental sem o fortalecimento da participação comunitária, sem um "empoderamento" da população, ou ainda sem o envolvimento dos diversos setores da administração pública. Não se trata de empoderar-se de algo, apenas por vias cognitivas, mas de empoderar-se de saberes que estão construindo o sujeito da ação.

Embora ações isoladas de educação ambiental venham sendo implementadas junto com a população da Cratera, dentre as quais pode-se citar a presença de um técnico da Secretaria Municipal do Verde e do Meio Ambiente do Município de São Paulo, e um curso de Astronomia oferecido pelo Planetário, ainda são poucas as ações desenvolvidas, e muitas delas ainda são implementadas dentro de uma lógica de educação como transmissão de conhecimentos. Cabe aos profissionais dos poderes públicos instituídos, como a Secretaria do Meio Ambiente do Estado de São Paulo, a Secretaria Municipal do Verde e do Meio Ambiente, SABESP, as 
Secretarias Municipais e Estaduais da Saúde, aos responsáveis pelas demais políticas públicas do local, repensarem interdisciplinarmente a possibilidade e a necessidade de implantar programas dos quais a comunidade possa participar, de forma efetiva, desde a fase de levantamento de prioridades e de problemas, até a fase de planejamento, de implementação e de avaliação das ações para a promoção de um ambiente saudável e sustentável.

Dentre as ações de educação ambiental mais criativas e mobilizadoras cabe ressaltar o trabalho desenvolvido pela SOS Mata Atlântica, no que se refere ao programa de monitoramento das águas da região, e as ações implementadas pela ACHAVE, no que concerne á organização de mutirões de limpeza das ruas e dos córregos do lugar.

Analisando todo o processo de construção do movimento de associativismo civil desenvolvido na Cratera da Colônia, pode-se afirmar que, embora a ACHAVE venha contribuindo de forma decisiva para a construção de uma problemática socioambiental local, ainda não há uma efetiva institucionalização de projetos voltados para o desenvolvimento local, ou ainda uma educação ambiental dirigida para a grande maioria da população residente na Cratera da Colônia. Os projetos implementados ainda estão voltados, mais especificamente, aos dirigentes do movimento e aos filiados da ACHAVE.

Embora no discurso dos dirigentes comunitários a necessidade de desenvolvimento de projetos para a região seja uma tônica recorrente, na prática, não há nenhum projeto institucionalizado em parcerias com os poderes públicos. No momento da pesquisa, havia uma parceria, em fase inicial com a organização SOS Mata Atlântica, para monitoramento das águas dos rios da região.

A partir dos dados coletados pode-se afirmar que a desarticulação de projetos no âmbito da comunidade se faz sentir. Embora todos possuam os mesmos objetivos - melhoria da qualidade de vida, desenvolvimento de projetos de geração de renda, projetos de atendimento a crianças em situação de exclusão, projetos voltados a capacitação para o trabalho de jovens - não há uma articulação entre os diversos setores organizados da população. Na prática, cada um desses setores desenvolve um 
trabalho isolado cujos resultados não atingem as expectativas da população local. É nítida a fragilidade das experiências experimentadas pelos diversos associativismos civis da Cratera da Colônia, que mostram as dificuldades de assimilar um modelo mais participativo e intersetorial. Apesar dos problemas observados na construção de um projeto de desenvolvimento voltado para a Cratera da Colônia, percebe-se que há condições políticas favoráveis para o estabelecimento de fóruns de discussão e construção de projetos conjuntos entre a Associação de Moradores, o Programa Saúde da Família, as escolas municipal e estadual e com instituições do Terceiro Setor.

Os resultados apontam também para mudanças no âmbito da vida pessoal daqueles que vem participando com mais assiduidade dos movimentos associativistas da região.

Cabe também à população, individualmente e também por meio de suas organizações de representação, inserir-se nas instâncias de atuação do Estado, de forma a subsidiar a adoção de práticas participativas para implantar programas, projetos e atividades ambientais, os quais representam, sem dúvida, atendimentos às necessidades sociais básicas e aos direitos sociais de cidadania, estabelecidos constitucionalmente.

\footnotetext{
"Todas as pessoas com quem conversamos e tentamos estabelecer uma parceria dizem - Escrevam um projeto, pois dinheiro tem!, mas o problema é que nós não sabemos como escrever tudo direitinho, dentro das normas estabelecidas e isso dificulta muito a possibilidade da gente concretizar todas as idéias que temos em mente!".
}

Destaca-se, ainda, o nível heterogêneo de participação e de informação dos diversos dirigentes comunitários locais, nos assuntos relativos a implementação de projetos de desenvolvimento socioambientais na Cratera da Colônia. Muitas ações, como mostraram os resultados, ainda ficam centradas, de forma preponderante, na 
figura do presidente e dos dirigentes da Associação ACHAVE. Uma das propostas viáveis para o estabelecimento de parcerias, com os demais setores da sociedade e da economia, seria o assessoramento por parte das universidades ou ainda por meio de ONGs, na construção e elaboração de projetos, bem como no empoderamento dessas comunidades na construção de processos avaliativos desses projetos, uma vez que uma das exigências das organizações financiadoras, além da implementação e monitoramento dos projetos, é a necessidade de todas as ações serem avaliadas.

Dentre as propostas de projetos factíveis de serem implementados na região, e que poderiam trazer uma maior sustentabilidade para as populações locais foram ressaltados, a partir da atual pesquisa, as seguintes:

- Projetos na área de turismo ambiental, uma vez há um grande potencial para esse fim, tanto pelas características geológicas do lugar, quanto pela exuberância da natureza que se mostra de várias formas: por meio de espécimes raras da fauna e flora local; por meio dos recursos hídricos da região, que se apresentam em forma de rios e de quedas d' água que podem ser encontrados nas trilhas e matas da região; dentro da área do turismo ambiental foram citadas as possibilidades do envolvimento dos jovens da região em projetos de capacitação para guias ambientais, dentro de princípios éticos e ambientalmente sustentáveis;

- projetos de cunho paisagístico, tais como: reconhecimento da flora local; viveiro de mudas e cultivo de bromélias, entre outras espécies nativas;

- projetos na área nutricional, que poderiam envolver as populações locais em hortas comunitárias, em projetos de apicultura e outros;

- projetos na área de educação e cultura, envolvendo os aspectos históricos, ecológicos e sociais do local; neste aspecto, foi enfatizado o desenvolvimento de um projeto para o fortalecimento comunitário, e para a valorização da identidade do lugar, a partir do uso de imagens;

- ainda na área de educação e cultura foi ressaltada a possibilidade de projetos envolvendo uma maior integração entre as culturas locais, tais como as 
comunidades indígenas, a comunidade alemã da região e as comunidades de imigrantes nordestinos;

- ainda no que se refere a aspectos culturais foi destacada também a importância de um projeto na recuperação das ferrovias locais. Em Engenheiro Marsilac encontra-se uma das primeiras estações férreas do país, a Estação Evangelista de Souza.

A maior parte dos problemas e propostas levantadas para um desenvolvimento local, nesta tese, são problemas e propostas partilhadas e endossadas também por outras comunidades, tais como da Cidade Nova América, da Barragem, do Jardim Silveira, do Embura, de Marsilac e das comunidades indígenas, dentre outras comunidades inseridas dentro da APA e fora do Condomínio Vargem Grande. Como os resultados dessa pesquisa apontaram também para uma fragilidade de articulação entre o pessoal do Condomínio Vargem Grande e essas outras comunidades, dentre as possibilidades para um maior desenvolvimento local desponta, como uma necessidade premente, uma maior integração com essas comunidades, uma vez que a maioria dos problemas são comuns e pertinentes a todas as populações que se inserem dentro da Área de Proteção Ambiental CapivariMonos. Só com a união das diversas forças locais é que poder-se-á caminhar para a resolução do conflito estabelecido na região como um todo. Dentro dessa perspectiva, cabe às organizações locais um maior empenho na busca e na construção de propostas e projetos coletivos para a região.

Nesse sentido, cabe às diversas instituições que vêm atuando na área, especialmente ao Conselho Gestor da APA e às universidades comprometidas com trabalhos de extensão universitária, desenvolverem um trabalho na região com o objetivo de propiciar uma rede de intercâmbio entre as diversas instituições, organizações locais e populações interessadas no desenvolvimento do local, visando articular os diversos setores da região para a busca de sustentabilidade de toda a Área de Proteção Ambiental do Capivari-Monos, a partir de um olhar multi, inter e transdisciplinar. 
No que se refere à metodologia, utilizou-se de recursos multivariados: de observações de reuniões, de festas populares, de atividades educativas; de entrevistas; de grupos focais; de registros fotográficos; de registros documentais. Essa metodologia mostrou ser bastante pertinente e apropriado para os objetivos propostos. Assim como Kuhnen (2002) concluiu em sua investigação, essa base diversificada e combinada entre si possibilitou abstrair, da concretude da vida diária, elementos importantes de teorização sobre o modo de vida e a construção da problemática socioambiental na localidade. Cabe destacar a importância do uso de imagens (um dos instrumentos utilizados nas entrevistas ou, por que não dizer, nos encontros com a população) que se mostrou bastante instigante, provocativa e, ao mesmo tempo, respeitosa com as representações dos sujeitos, uma vez que a construção e a expressão destes foram consideradas, do ponto de vista individual e social, à medida que buscou-se integrar a relação dos sujeitos com uma materialidade, sem perder de vista a individualidade cultural, a participação social e o grupo de pertencimento das pessoas. 


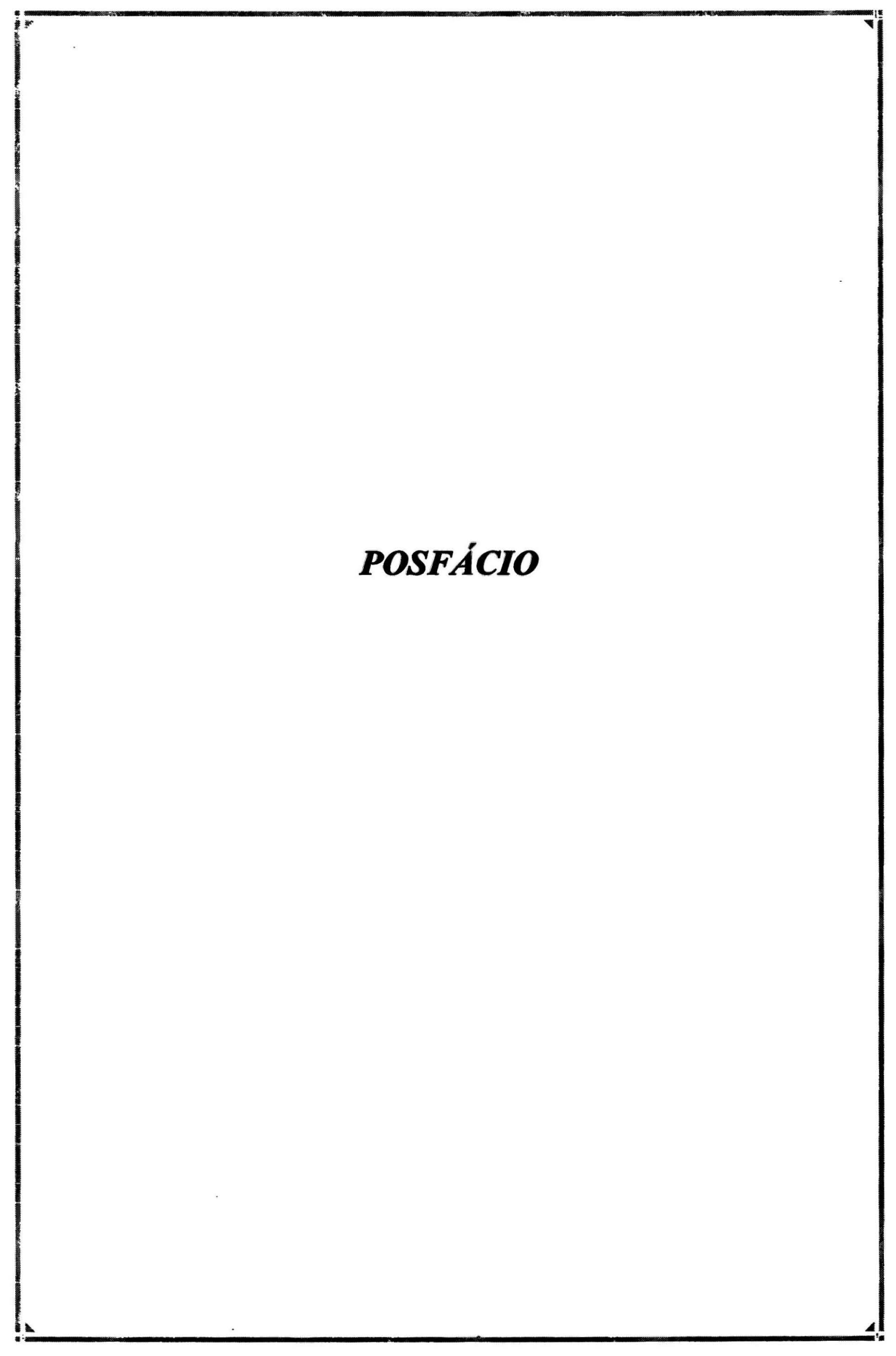


O nosso intuito no decorrer dessa tese foi o de mostrar que a questão ambiental, ou a problemática ambiental, ou ainda, os problemas ecológicos, como quer que a chamemos, revelam-se como construções sociais e históricas. Portanto, não se trata de refletir sobre um conhecimento fechado, estanque e possuidor de um único núcleo mas trata-se, fundamentalmente, de uma construção de um processo social, de uma sociedade sustentável, ou ainda da construção de um lugar utópico, como a "sombra de uma mangueira" a que se referia Paulo Freire.

Levamos em conta que os problemas socioambientais são problemas eminentemente sociais, gerados e perpassados por um conjunto de processos sociais, como argumenta LEFF (2001), e como tais, só vieram à tona porque, enquanto ambientes construídos, não se encontram alheios à vida social, mas são penetrados e reordenados por ela, confundindo, dessa maneira, o que é natural e o que é social.

E se consideramos, ainda, que não existe um único ambiente, mas sim vários ambientes social, geográfica, histórica e culturalmente determinados, e que os problemas ambientais são, simultaneamente problemas de saúde, pois afetam os seres humanos e as sociedades em múltiplas e simultâneas escalas e dimensões, nesse sentido, concordamos com FREITAS (2003), quando este afirma que, há que se considerar que um problema ambiental corresponde a uma multiplicidade de problemas ambientais simultâneos, que envolvem diferentes e conflituosas concepções de sociedade. Esses problemas, por sua vez, envolvem necessariamente, processos sociais, políticos, econômicos e culturais, bem como uma multiplicidade de atores sociais, com diferentes noções e interesses acerca desses processos sociais e de suas maneiras de conduzir as resoluções. Assim, buscar a solução dos problemas somente a partir do conhecimento "dos peritos", ou ainda somente no âmbito das ciências naturais e das engenharias, é buscar a solução de forma muito limitada.

Por outro lado, pensarmos a questão ambiental na contemporaneidade, no campo das Ciências Sociais, é um desafio para nós pesquisadores da área. Nesse sentido, tem se mostrado necessário ampliar os nossos horizontes para referências formuladas em outros campos disciplinares. Com já enfatizamos anteriormente, tendo em vista que o tema ambiental encerra dificuldades diversas ligadas ao entrelaçamento de aportes de diferentes disciplinas ou especialidades técnicas e 
teóricas, reforça-se, dessa maneira a exigência, aos investigadores de uma maior abertura para novas e inesperadas conexões que, porventura, possam aparecer no decorrer da investigação.

Há que se ampliar o olhar para análises transdisciplinares, atentando para os riscos existentes, pois, na busca da interdisciplinaridade muitos acabam por unificar os discursos cientificos, homogeneizando suas estruturas conceituais dentro de explicações biologistas dos processos históricos (LEFF 2001).

Moraes, ao abordar a questão da interdisciplinaridade no estudo da questão ambiental, traz à tona o risco do que ele denomina "naturalismo", isto é, posturas que tomam a problemática ambiental somente no seu aspecto biológico e natural, deixando de lado a dimensão social que o tema encerra. "Tratam daqueles discursos que vêm o homem apenas como fator de alteração do equilibrio de um meio: daquelas análises que não falam de sociedade mas apenas da ação antrópica, uma variável a mais mum conjunto de fatores basicamente naturais; a relação homemnatureza, assim, sendo concebida sem a mediação das relações sociais" (MORAES 1998).

Em face de estas considerações, e em especial, devido ao fato de a questão socioambiental se revelar como uma construção histórica, entendemos que, ao refletir e conceituar a problemática socioambiental, faz-se necessário contextualizá-la geopoliticamente, mundializá-la e adjetivá-la, integrando-a na lógica da industrialização e da globalização ora em decurso. Acreditamos que este seja o caminho para se introduzir, aqui, as possibilidades que nos oferecem conceitos provenientes de campos disciplinares e orientações epistemológicas diferentes e aparentemente distantes. Aproximações com autores de outras áreas, como a antropologia, a geografia, a sociologia urbana, a economia política, a psicologia social e demais áreas oferecem subsídios que permitem a elaboração de argumentos a favor de uma postura sobre a produção do conhecimento, entendida como produções parciais, locais e posicionadas, em contraposição à produção do conhecimento neutra e não comprometida com o processo de construção, interpretação e mudança dos fenômenos sociais, baseada na compreensão da 
realidade como algo externo, susceptível de ser captada na sua "totalidade" através de procedimentos de generalização e simplificação dos fenômenos sociais.

Ao discorrer sobre a urbanização brasileira", SANTOS M (1993) ressalta a importância de circunscrever o fenômeno, identificar sua especificidade, mensurar sua problemática, para conseguir uma interpretação abrangente, embora o próprio autor dê conta que nenhuma ciência pode oferecer a representatividade completa do conhecimento. Para este autor, só o conjunto das ciências econômicas, sociais, políticas e outras é que poderá dar conta da realidade em estudo.

As transformações ocorridas no mundo a partir dos anos 1960, incluindo desde os movimentos de descolonização, os movimentos de direitos civis até o surgimento da economia globalizada provocaram, no âmbito das ciências sociais, profundas mudanças nas suas concepções sobre o objeto de análise, na linguagem da análise e na posição do pesquisador. Concordamos com GEERTZ (2001) e SANTOS BS (2002) quando estes enfatizam que há uma tendência, no campo das ciencias sociais, em desviar, cada vez mais a atenção, de explicações embasadas em leis gerais. Estes autores argumentam, ainda, que os pressupostos objetivistas sobre a produção da teoria, a linguagem e a postura de pesquisador neutro, não se sustentam mais, devido à mudança da agenda social $e$ às novas exigências da contemporaneidade.

Decorrente dessa nova postura surge um paradigma emergente nas investigações sociológicas, marcado por interesses mais centrados em contextos históricos e políticos, cujas análises sociais voltam-se para aspirações e demandas de grupos freqüentemente nomeados como marginais, fortemente influenciado pelos movimentos da contracultura, como o ambientalismo, o feminismo, os movimentos gays, os movimentos dos indígenas, a luta dos negros e os das minorias raciais, em situações de desigualdade e opressão, bem como em fatores como a ocidentalização, o papel centralizador da mídia, a invasão da cultura material, e as diferenças de classes, gêneros, etnias e orientações sexuais. Deste modo, a reorientação no âmbito das ciências sociais faz parte de uma dinâmica maior de movimentos sociais e de reformulações epistemológicas e heurísticas do conhecimento. 
A partir dessa nova reorientação das ciências sociais podemos enfatizar a pertinência de uma sociologia ambiental, direcionando seu olhar para o modo como as pessoas constroem suas próprias histórias, sua habitabilidade e sua relação com o ambiente natural e construido, bem como as suas relações de poder intrínsecas, tanto no âmbito mais macro como as de âmbito mais microestruturais.

Apoiados nesta perspectiva e nos processos de interpretação da realidade, os pesquisadores também são sujeitos posicionados em um contexto particular, e se auto-reposicionam na medida que, eles mesmos, vivem a experiência da compreensão de outras culturas e de outras formas de construção social da realidade. Os investigadores começariam assim suas pesquisas com uma serie de questionamentos, os quais são revistos à luz do processo da investigação para, no final, desembocarem em perguntas que não tinham sido consideradas no início. Esse movimento constante de respostas recebidas, reflexividade e negociação de sentidos é parte importante da postura defendida por diversos cientistas sociais e pelos psicólogos sociais de linha construcionista, como nos diz GARCIA (2004).

Do ponto de vista da construção de um conhecimento no campo acadêmico, esta tese, que se iniciou a partir do aporte de um só referencial teórico, no decorrer de seu desenvolvimento demonstrou que o tema em questão, a problemática ambiental ou a problemática ecológica, como quer que a chamemos, exige de nós, pesquisadores, que deixemos a zona de conforto, que é o nosso nicho acadêmico, para buscarmos novas e inesperadas conexões, como a que trazemos à guisa de conclusão.

Apesar do caráter incipiente de uma discussão ambiental no campo do materialismo histórico, como argumentam os grandes teóricos da sociologia ambiental como HANNIGAN (1995); BUTTEL (2000); GOLDBLATT (1996); LEFF (2001), pensamos que para o desenvolvimento de uma racionalidade ambiental fundada nos princípios de uma sociedade sustentável,baseada na ética e na gestão participativa dos recursos ambientais, o pensamento do grande teórico Antonio Gramsci, pensador marxista, cuja obra é perpassada por uma visão crítica e histórica dos processos sociais e que, de dentro do cárcere, debruçou-se sobre a realidade de sua época, enquanto totalidade, desvendando suas contradições e 
antagonismos, possa se constituir em um caminho fecundo na pesquisa científica e nas ações implementadas para o enfrentamento da problemática ambiental.

No tocante à busca de um caminho para a crise ambiental, à luz do pensamento gramsciano, faz-se necessário resgatar o caráter histórico das sociedades e sua interrelação com os ecossistemas, além de reforçar e valorizar as possibilidades associativas que vêm despontando nas sociedades contemporâneas.

É de grande interesse conhecer como as comunidades locais organizam-se para minimizar, eliminar, ou enfrentar os problemas ambientais de grandes centros urbanos, visto que a participação das populações vem se tornando um mecanismo cada vez mais importante para o enfrentamento das dificuldades geradas pela forma de organização social, política e econômica do país. Gramsci, em seu tempo, já afirmava a importância de integração das massas nas velhas formas políticas. Rejeitando as soluções do fascismo e criticando as tendências de centralização do poder, Gramsci sustentava que uma nova civilização só poderia vir à luz pelo ingresso, na história, das massas livres e democraticamente organizadas (GRAMSCI $1966 ; 1979 ; 1984)$.

Em um cenário em que os problemas relativos ao poder são cada vez mais complexos, assim como se complexificam, também, as formas de estruturação das classes sociais e de sua relação com a política, a emergência de novos movimentos sociais indica a possibilidade de construção de uma nova sociabilidade, de uma verdadeira transformação social e da construção de uma nova hegemonia, na qual não só deva haver uma reestruturação da economia (infraestrutura), mas também no campo das idéias e valores (superestrutura) pois, para Gramsci, a luta pela hegemonia traz, implícito, um debate sobre a cultura, enquanto espaço de desenvolvimento da consciência crítica do ser social, o que o torna capaz de intervir na realidade (BOBBIO, 1982).

Retomando a atualidade e a importância do pensamento de Gramsci para o enfrentamento da problemática ambiental, cabe ressaltar que, ao apostar no potencial mobilizador da sociedade civil, Gramsci desloca o eixo principal da ação política, retirando-a do âmbito das instituições burocráticas e administrativas e movendo-a para o terreno criativo das diversas organizações sociais dos setores populares, o que 
abre um leque de inimagináveis possibilidades de transformaçôes e de novas utopias. Mais do que o entendimento da sociedade civil como detentora de um de hegemonia política e cultural de um grupo social sobre toda a sociedade, para Gramsci, a sociedade civil será, especialmente, um momento da catarse, no qual ocorre a elaboração superior (passagem) da estrutura para a superestrutura na consciência dos homens e das mulheres, isto é, do econômico (necessidade) para o ético-político (consciência da necessidade ou seja, a liberdade) (ESTENSSORO (2003).

A parcela da sociedade civil representada pelas novas organizações democráticas, surgidas com o intenso processo de socialização da política e que se expressa através dos partidos, dos sindicatos, dos movimentos sociais de diversas ordens, das associações profissionais, das comissões de fábrica, das organizaçõesnão-governamentais, de organizações culturais, dentre outras, passa a desempenhar um papel fundamental nas relações Estado/Sociedade, principalmente na defesa de direitos e interesses universais, como é o caso da questão ambiental, diminuindo dessa forma os poderes coercitivos do Estado, e ampliando as formas de acesso e participação nos processos decisórios, defininindo assim, uma prioridade do público sobre o privado. Como nos adverte GRAMSCI,(1984), as funções de domínio e coerção vão sendo substituídas pelas de hegemonia e consenso, e a sociedade política vai sendo reabsorvida pela sociedade civil.

Como vimos no decorrer dessa tese, longe de ser um dado natural da ação do ser humano ou um fenômeno externo a ele que deva ser controlado, a problemática ambiental expressa os conflitos nas relações sociais, e seu enfrentamento, no nosso modo de entender, deve ser remetido para o campo das lutas políticas, apoiando-nos em Gramsci.

A natureza, objeto da política ambiental, é a natureza "natural", mas também é a natureza "construida" e concreta, de acordo com a sua organização interna, sua cultura e sua técnica, sua distribuição de riquezas e seu poder político, isto é: é fruto de seu momento histórico; e a crise ecológica configura-se muito além de algo natural, ou um mero objeto das atenções do Estado: evidencia-se como uma questão encravada no campo da sociedade civil, concebida a partir da conceituação de 
Gramsci, que a entendia como o momento da consciência ativa no campo ideológico e cultural, que não se confunde com o poder político ou com a estrutura do Estado.

Para Gramsci, o Estado Moderno não pode ser entendido como um sistema burocrático-coercitivo. As suas dimensões não podem se limitar aos instrumentos exteriores de governo, mas deve abarcar também a multiplicidade dos organismos presentes na sociedade civil, palco onde se manifestam a livre iniciativa dos cidadãos e das cidadãs, seus interesses, suas organizações, sua cultura e valores e onde se estabelecem as bases do consenso e da hegemonia.

Nesse sentido, à luz do pensamento gramsciano, a sociedade civil é, antes de tudo, o extenso e complexo espaço público não-estatal no qual se estabelecem as iniciativas dos sujeitos modernos com sua cultura, com seus valores éticos e políticos e suas dinâmicas associativas. É o lugar de grande importância política, em que as classes subalternas são chamadas a desenvolver as suas convicções e a lutar por um novo projeto hegemônico de sociedade formando, dessa maneira, um "bloco histórico" o que, segundo COUTINHO (1998) seria um "....bloco reformador $e$ democrático como proposta estratégica de "construção alternativa", no seio da esquerda, de uma "terceira via" entre o reformismo conservador da atual socialdemocracia e o rupturismo anacrônico de matriz bolchevique".

Um outro panorama que apresentamos nesta tese foi que, pensar na questão socioambiental, remete-nos a um questionamento tanto sobre o papel das metrópoles e das cidades, como sobre a reconstituição dos espaços comunitários, desarticulados por um século e meio de capitalismo, como enfatiza DOWBOR, apontando para novas dimensões e possibilidades de desenvolvimento social.

"E estes diversos espaços em plena transformação $e$ rearticulação abrem novas dimensões para a inserção do individuo no processo de reprodução social, permitindo talvez a reconstituição de um ser humano completo a partir dos segmentos de homo oeconomicus, de homo ludens, de homo culturalis hoje fragmentados, numa economia que se unificou na medida em que desarticulou a sociedade". (DOWBOR 1995). 
Nesse sentido, para que essas dimensôes e possibilidades apontadas por DOWBOR possam ser concretizadas, apostamos na importancia do papel do intelectual orgânico e das açoes desenvolvidas pelos profissionais que atuam no campo, sejam eles da área ambiental, da saúde, cientistas, educadores e educadoras. entre outros, para que esse ser humano completo seja reconstituído e uma nova sociedade mais sustentável possa emergir.

Concordando com a interpretação que faz BOBBIO (1982) acerca do conceito de sociedade civil em Gramsci, em que o partido e a hegemonia se constituem em elementos da sociedade civil, pelos quais é viabilizada a formação de uma vontade coletiva capaz de transformar a sociedade e o Estado em difusores e realizadores de uma nova concepção de mundo, apostamos ainda no papel desempenhado pela sociedade civil, entendida como "(...) lugar onde discursos práticos traduzem uma intersubjetividade comunicativamente compartilhada de que é possivel erradicar a pobreza e diminuir a desigualdade, seja como lugar da ação estratégica do partido em luta política por uma hegemonia que permita transformar a realidade concreta em direção a uma situação histórica onde a pobreza e a desigualdade não existam. Em outros termos, a sociedade civil como espaço público onde se luta para formar uma cidadania das pessoas pobres sincronizadamente com o desenvolvimento das sociedades no processo de globalização, isto é, uma cidadania planetária condizente com a sociedade global(....)" (ESTENSSORO, 2003).

Pensamos que na busca da transformação dessa realidade, na qual possa haver uma interação entre os vários atores envolvidos no processo, é que devemos agir, entim. na construção dessa sociedade utópica. Só assim, acreditamos poder-se-á caminhar para uma melhoria da qualidade socioambiental das populações das grandes e pequenas cidades, especialmente aquelas que mais são atingidas pela degradação socioambiental - a população mais pobre.

Fazendo uma conexão do caminho apontado por DOWBOR com os pressupostos gramscianos, gostariamos de encerrar essa tese com dois questionamentos: primeiro, será que esta história que contamos aqui nesta tese, a partir das vozes da Cratera, não nos mostra algo sobre esse homem completa e essa 
mulher completa que estão desabrochando? E segundo: poderia a construção de uma sociedade sustentável ser entendida como uma catarse, conceito que Gramsci utiliza para referir-se à passagem do momento corporativo ao momento ético-político, ou ainda, a passagem da "classe em si" para a "classe para si", ou seja, a tarefa ontológico-dialética de construção de um novo bloco histórico, entendido como o momento em que todas as classes conseguem elaborar um projeto para toda a sociedade por meio da ação coletiva?

\begin{abstract}
"Pode empregar a expressão "catarsis" para indicar a passagem do momento puramente econômico (ou egoísta-passional) ao momento ético-politico, isto é, a elaboração superior da estrutura em superestrutura na consciência dos homens. Isto significa também, a passagem do "objetivo ao subjetivo" e da" necessidade à liberdade". A estrutura da força exterior que subjuga o homem, assimilando-o e o tornando passivo, transforma-se em meio de liberdade, em instrumento para criar uma forma ético-politica, em fonte de novas iniciativa" (GRAMSCI 1966, p.53).
\end{abstract}

Buscar respostas a essas indagações poderia ser o tema de uma próxima investigação, mas esta, como conhecimento provisório, está concluída! 
REFERÊNCIAS 
Abric JC. A abordagem estrutural das representaçóes sociais. In: Moreira ASP. Oliveira DC. organizadores. Estudos interdisciplinares de representação social. Goiania. GO: AB: 1998. p. 27-38.

André LM. Representações e práticas preventivas da Aids em coletores de lixo no município de São Paulo. São Paulo; 1999. [Tese de Doutorado - Faculdade de Saúde Pública da USP].

Arato A. Cohen J. Sociedade civil e teoria social. In: Avritzer L. Sociedade civil e democratização. Belo Horizonte: Del Rey; 1994. p. 149-82.

Arruda AMS. Uma contribuição às novas sensibilidades com relação ao meio ambiente: representações sociais de grupos ceologistas e ecofeministas cariocas. Sào Paulo; 1995. [Tese de Doutorado - Instituto de Psicologia da USP].

Ayuste A. A pedagogia critica e a modernidade. Pátio - Revista Pedagógica.1997; $1(2)$.

Balandier G. O contorno - poder e modernidade. Rio de Janciro: BCD União de Editoras: 1997.

Bardin L. Análise de conteúdo. Lisboa: Ediçōes 70; 1995.

Beck U. The risk society. Londres: Sage; 1992.

Beck U. A reinvenção da politica: rumo a uma teoria da modernicação reflexiva. In: Giddens A, Beck U, Lash S. Modernização reflexiva: política, tradição e estética na ordem social moderna. São Paulo: Editora da Universidade Estadual Paulista; 1995. p. 11-71.

Beck U. Risk Society reviseted: theory, polities and research programmes. In: Adam B. Beck U, Loon JV. The risk society and beyond: critical issues for social theory. London: Sage Publications; 2000 .

Bellenzani MLR. A APA municipal do Capivari-Monos como uma estratégia de proteção aos mananciais da região metropolitana de São Paulo. São Paulo; 2000 ). [Dissertaçào de Mestrado - Programa de Pós-Graduação em Ciência Ambiental da USP].

Benevides MVM. A cidadania ativa: referendo, plebiscito e iniciativa popular. São Paulo: Ática; 1991.

Bobbio N. O conceito de sociedade civil. Rio de Janeiro. Graal;1982.

Bordenave JG, organizador. O que é participação. São Paulo: Brasiliense; 1983.

Borja J, Castells M. Las grandes ciudades em la década de los noventa. Madri: Editorial Sistema; 1990. 
Bourdieu P. O desencantamento do mundo: estruturas econômicas e estruturas temporais. São Paulo: Editora Perspectiva; 1979.

Bourdieu P. Esboço de uma teoria da prática. In: Ortiz R, organizador. Pierre Bourdieu. São Paulo: Editora Ática; 1983. p. 46-81.

Bourdieu P, coordenador. A miséria do mundo. $3^{\text {a }}$ ed. Petrópolis, RJ: Vozes; 1999.

Bonduki N. Origens da habitação social no Brasil. São Paulo: Estação Liberdade; 1998.

Brandão CR. O que é a educação. São Paulo: Brasiliense; 1981. (Coleção Primeiros Passos).

Brasil. Ministério da Saúde. Promoção da Saúde: Carta de Ottawa, Declaração de Adelaide, Sundsval e Santa Fé de Bogotá. Tradução de Luis Eduardo Fonseca, Brasília; 1996.

Brasil. Comissão de Defesa do Consumidor, meio ambiente e minorias. Brasília: 1999.

Brüseke FJ. O problema do desenvolvimento sustentável. In: Cavalcanti C, organizador. Desenvolvimento e natureza: estudos para uma sociedade sustentável. São Paulo: Cortez Editores; 1995. p. 29-40.

Buss PM, Ignarra RM. Promoção da saúde. Brasília: Ministério da Saúde; 1996.

Buttel FH. Sociology and the environment: the winding road toward human ecology. Internacional Social Science Journal. 1986; 38(3):337-56.

Buttel FH. New directions in environmental sociology. Annual Review Sociology. $1987 ; 13: 465-88$.

Buttel FH. World society, the nation-state, and environmental protection (Comment on Frank, Hironaka and Schofer). American Sociology. 2000; 65:1 17-21.

Calió AS. Relações de gênero na cidade - uma contribuição do pensamento feminista à geografia urbana. São Paulo; 1991. [Tese de Doutorado Departamento de Geografia da Faculdade de Filosofia, Letras, Ciências Sociais e História da USP].

Calvino I. As cidades invisíveis. $2^{\text {a }}$ ed. São Paulo: Companhia das Letras: 2003.

Camargo A. Os pioneiros do desenvolvimento sustentável: Os melhores parceiros, as melhores práticas. Disponível em <URL: http://www.mma.gov.br> [2004 Nov 01].

Capra F. Crise e Transformação. In: O Ponto de mutação. São Paulo: Cultrix; 1982. p. $17-46$. 
Carson R. Silent spring. New York: Reprinted in Penguin Classics; 1962.

Carvalho EA, organizador, Fernandes F, coordenador. Godelier - Antropologia. São Paulo: Editora Ática; 1981. (Grandes Cientistas Sociais, v. 21).

Castoriades C, Cohn-Bendit D. Da ecologia à autonomia. São Paulo: Brasiliense; 1981.

Castro MG, Abramovay M. Gênero e meio ambiente. São Paulo: Cortez Editora; 1997.

Catton WR Jr, Dunlap RE. Competing functions of the environment: living space, supply depot and waste repository; 1989. [Documento apresentado no Encontro Anual da Sociedade de Sociologia Rural, Salt Lake City, Utah.].

Catton WR Jr, Dunlap RE. Environmental sociology: a new paradigm. Am. Sociol. $1998 ; 13(1)$.

Chauí M. Ética e universidade. Rev. Universidade e Sociedade. 1995; 8:82-7.

Coelho JAT et al. Setor agrícola da zona rural do município de São Paulo e seu papel na política ambiental. In: A questão ambiental urbana. São Paulo: Secretaria do Verde e do Meio Ambiente; 1993. p. 459-73.

[CMMAD] Comissão Mundial sobre Meio Ambiente e Desenvolvimento. Nosso futuro comum. $2^{a}$ ed. Rio de Janeiro: Editora Fundação Getúlio Vargas; 1991.

Coelho AR. O urbano e o sanitário na globalização. Estudo das questões urbanas e sanitárias da cidade de Florianópolis - SC. São Paulo; 1998. [Tese de Doutorado - Faculdade de Saúde Públlica da USP].

Coutinho CN. Gramsci no Brasil: recepção e usos. In: Moraes, JQ (organizador) História do marxismo no Brasil. Campinas. Unicamp;1998, V.III, .pp. 123-157.

Crespo S, Leitão P. O que o brasileiro pensa da ecologia. Rio de Janeiro: CEPEM/CNPq/ISER; 1992.

Crósta AP. Elas podem ser gêmeas. Jornal da Unicamp. Disponível em <URL: http://www.unicamp.br/unicamp/unicamp hoje/ju/maio2004/ju250pag03.html > [2004 Nov 05].

Crósta AP, Vieira CK, Choudhuri A. Impact features from Vargeão Dome, southern Brazil. Meteoritics \& planetary science. Tucson, AZ, USA, v.39, n. Supplement, p.A-52 - A-52, 2004.

Cunha IA. Sustentabilidade e poder local: a experiência de política ambiental em São Sebastião, costa norte de São Paulo (1989-1992). São Paulo; 1996. [Tese de Doutorado - Faculdade de Saúde Pública da USP]. 
Da Matta R. Impacto da Herança Cultural Brasileira nas atitudes para com a natureza e ao meio ambiente. Disponível em <URL: http://www.memoriadomeioambiente.com.br/projeto/livros_dep.asp > [2004 Nov 01].

Dallari D. Direito de participação. In: Sorrentino M, organizador. Ambientalismo e participação na contemporaneidade. São Paulo: EDUC; 2001 . p. 85-114.

Denzin N. The Research act. Chicago: Aldine; 1970.

Di Chiro G. Environmental educacion and question of gender: a feminist critique. In: Robottom I, editor. Environmental educacion: practice and possibility, Geelong: Deakin University; 2000. p. 23-48.

Diegues ACS. O mito moderno da natureza intocada. São Paulo: HUCITEC; 1996.

Dowbor L. Descentralização e meio ambiente. In: Bursztyn M, organizador. Para pensar o desenvolvimento sustentável. $2^{\text {a }}$ ed. São Paulo: Editora Brasiliense; 1994. p. 103-12.

Dowbor L. Da globalização ao poder local: a nova hierarquia dos espaços. São Paulo em Perpectiva. 1995; 9(3): 3-10.

Dowbor, L. O que é poder local? São Paulo: Brasiliense; 1995. (Coleção Primeiros Passos).

Dowbor L. A reprodução social - Propostas para uma gestão descentralizada. $2^{\text {a }}$ ed. Petrópolis, RJ: Editora Vozes; 1999.

Dunlap RE, Catton WR Jr. Environmental sociology. Annual Review of Sociology. 1979; 5:243-73.

Dunlap RE. From environmental to ecological problems. In: Calhoun C, Ritzer G, organizadores. Social Problems. New York: McGraw-Hill; 1993.

Dürkheim E. Lês formes élémentaires de la vie religieusse. Paris: Presses Universitaires de France; 1968.

Dürkheim E. Educação e Sociologia. $4^{\mathrm{a}}$ ed. São Paulo: Editora Melhoramentos; 1955.

Dutra MJS. O discurso ecológico na televisão: um caso em estudo. Belém: Universidade Federal do Pará - Núcleo de Meio Ambiente; 1994. (Série Estudos do NUMA, v. 3).

Eckersley R. Environmental and political theory; toward and ecocentric approach, London: UCL Press, 1995.

Evers T. Identidade: a face oculta dos novos movimentos sociais. São Paulo: Novos Estudos CEBRAP. 1984; 2(4):11-23. 
Estenssoro L. Capitalismo, desigualdade e pobreza na América Latina. São Paulo; 2003. [Tese de Doutorado - Departamento de Sociologia da Faculdade de Filosofia, Letras e Ciências Humanas da USP].

Ferreira LC, Siviero SO. Ambiente e cidades em direção a uma nova agenda. São Paulo em Perspectiva; 1996. 10(3):60-9.

Ferreira LC, Viola E. Introdução. In: Incertezas de sustentabilidade na globalização. Campinas, SP: Editora da UNICAMP. 1996; p. 7-14.

Ferreira LC. Sociologia ambiental, teoria social e a produção intelectual no Brasil. São Paulo: Boitempo Editorial; 1998.

Ferreira LC. A Questão ambiental: sustentabilidade e políticas públicas no Brasil. São Paulo: Boitempo Editorial; 1998.

Ferreira LC. Sociologia Ambiental Brasileira: um levantamento provisório. Ambiente \& Sociedade. 2002; 10:27-43.

Foucault M. Microfísica do poder. Rio de Janeiro: Graal; 1979.

Freire P. Educação como Prática da Liberdade. $8^{\mathrm{a}}$. Ed. Rio de Janeiro, Paz e Terra, 1978.

Freire P. Pedagogia do Oprimido $18^{\mathrm{a}}$. Ed. Rio de Janeiro, Paz e Terra, 1988. (Coleção O Mundo Hoje v. 21).

Freitag B. Escola, estado e sociedade. São Paulo: Edart; 1978.

Freitas CM. Problemas ambientais, saúde coletiva e ciências sociais. Ciência \& Saúde Coletiva. 2003; 8(1):137-50.

Fundação IBGE. Censo Demográfico de 2000. Disponivel em: <URL: http://www.fseade.gov.br > [2004 Nov 01].

Fundação SEADE. Informações dos Municípios Paulistas. Disponível em: <URL: http://www.fseade.gov.br> [2004 Nov 01].

Gaffo L. Mitos e ritos na relação homem/natureza: um caso - a ocupação da Cratera da Colônia, Parelheiros, São Paulo. São Paulo; 1998. [Dissertação de Mestrado - Departamento de Geografia da Faculdade de Filosofia, Letras e Ciências Humanas da USP].

Garanhuns V. Capela do Socorro: A história que o povo conta. São Paulo: ACHAVE; 1995.

Garcia MC. A linguagem dos riscos e sujeitos posicionados: o uso de agrotóxicos no Vale do Quíbor, Venezuela. São Paulo, 2004. [Tese de Doutorado - Pontifícia Universidade de São Paulo]. 
Geertz G. A interpretação das culturas. Rio de Janeiro: Livros Técnicos e Científicos Editora; 1989.

Geertz G. O saber local. 4a ed. Petrópolis, RJ: Editora Vozes; 2001.

Geertz G. Nova luz sobre a antropologia. Rio de Janeiro: Jorge Zahar Editor; 2001.

Giddens A. As conseqüências da modernidade. São Paulo: Editora da Universidade Estadual Paulista; 1991.

Giddens A. A transformação da intimidade. São Paulo: Editora da Universidade Estadual Paulista; 1993.

Giddens A, Beck U, Lash S. Modernização reflexiva: política, tradição e estética na ordem social moderna. São Paulo: Editora da Universidade Estadual Paulista; 1995.

Giddens A. Risco, confiança, reflexividade. In: Giddens A, Beck U, Lash S. Modernização reflexiva: política, tradição e estética na ordem social moderna. São Paulo: Editora da Universidade Estadual Paulista; 1995. p. 219-34.

Giddens A. A vida em uma sociedade pós-tradicional. In: Giddens A, Beck U, Lash S. Modernização reflexiva: política, tradição e estética na ordem social moderna. São Paulo: Editora da Universidade Estadual Paulista; 1995. p. 74-133.

Giddens A. A terceira via: reflexões sobre o impasse político atual e o futuro da social-democracia. Rio de Janeiro: Editora Record; 1999.

Godelier M. A racionalidade dos sistemas econômicos. In: Carvalho EA, organizador, Fernandes F, coordenador. Godelier - Antropologia. São Paulo: Editora Ática; 1981. (Grandes Cientistas Sociais, v. 21). p. 37-58.

Gohn MG. Teorias dos movimentos sociais: paradigmas clássicos e contemporâneos. São Paulo: Edições Loyola; 1997.

Goldblatt D. Teoria Social e Ambiente. Lisboa: Instituto Piaget; 1996.

Gottdiener M. A produção social do espaço urbano. São Paulo; EDUSP, 1993.

Gramsci A. Concepção dialética da história. Rio de Janeiro: Civilização Brasileira; 1966.

Gramsci A. Os intelectuais e a organização da cultura. Rio de Janeiro: Civilização Brasileira; 1979.

Gramsci A. Maquiavel, a política e o estado moderno. Rio de Janeiro: Civilização Brasileira; 1984.

Gramsci A. Cadernos do cárcere. Rio de Janeiro: Civilização Brasileira; 2001 v.4. 
Grieve RAF, Robertson PB. The terrestrial cratering record, I current status of observations. Icarus. 1979; 38:212-29.

Grostein MD. A cidade clandestina: os ritos e os mitos. O papel da irregularidade na estruturação do espaço urbano no município de São Paulo. São Paulo; 1987. [Tese de Doutorado - Faculdade de Arquitetura e Urbanismo da USP].

Guareschi NMF. A criança e a representação social de poder e autoridade: negação da infầncia e afirmação da vida adulta. In: Spink $\mathrm{MJ}$, organizador. O Conhecimento no cotidiano: as representações sociais na perspectiva da psicologia social. São Paulo: Editora Brasiliense; 1993. p. 212-33.

Guattari F. As três ecologias. Campinas: Papirus Editora; 1995.

Guivant JS. A Trajetória das Análises de Risco: da periferia ao centro da teoria social. ANPOCS. 1998; 46: 3-48.

Guivant JS. Conflitos e negociações nas políticas de controle ambiental: o caso da suinocultura em Santa Catarina. Ambiente \& Sociedade 1998; 1(2):101-23.

Guivant JS. Reflexividade na sociologia de risco: conflitos entre leigos e peritos sobre os agrotóxicos. In: Qualidade de vida e riscos ambientais. Niteroi, RJ: UFF; 2000, p. 281-303.

Guivant JS. Sustentabilidade e métodos participativos: os riscos dos pressupostos realistas. [Trabalho apresentado no Congresso Mundial da International Sociological Association, Brisbane, Austrália, realizado entre 8-13 de julho de 2002].

Günther WMR, Ribeiro H, Araujo JM. Avaliação qualitativa e participativa de projetos: uma experiência a partir de pesquisa em educação ambiental e saneamento do meio. Rev Saúde e Sociedade. 2002; 11(2):107-128.

Günther WMR, Ribeiro H. Urbanização, modelo de desenvolvimento e a problemática dos resíduos sólidos urbanos. In: Ribeiro WC, organizador. Patrimônio Ambiental Brasileiro. São Paulo: EDUSP - Editora da Universidade de São Paulo, 2003. p. 469-89.

Günther WMR, Ribeiro H. A integração entre a educação ambiental e o saneamento ambiental como estratégia para a promoção da saúde e do meio ambiente sustentado. Biblioteca Virtual de Saúde Pública; 2003.

Hachiro J. Crateras por impacto de corpos extraterrestres - Astroblemas. Disponível

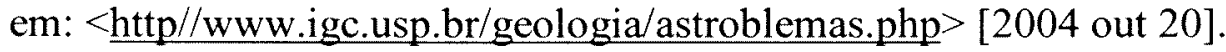

Haguette TMF. Metodologias qualitativas na sociologia. Petrópolis, RJ: Editora Vozes; 1990. 
Hannigan JA, Sociologia ambiental - a formação de uma perspectiva social. Lisboa: Instituto Piaget; 1995.

Harré J, Brockmeier J, Mühlhäusler P. Greenspeak: A Study of Environmental Discourse. London: Sage Publications; 1999.

Harvey D. A condição pós-moderna. São Paulo: Edições Loyola; 1992.

Heller A. O cotidiano e a história. São Paulo: Editora Paz e Terra; 1970.

Herculano SC. Sociologia Ambiental: origens, enfoques metodológicos e objetos. Rev. Mundo e Vida: alternativas em estudos ambientais, UFF/PGCA - Riocor. $2000 ; 45-55$.

Hogan DJ. Migração, ambiente e saúde nas cidades brasileiras. In: Hogan DJ, Vieira $\mathrm{PF}$, organizadores. Dilemas socioambientais e desenvolvimento sustentável. $2^{\mathrm{a}}$ ed. Campinas: Editora da Unicamp; 1995. p. 149-67.

Hogan DJ. A qualidade ambiental urbana: oportunidades para um novo salto. São Paulo em Perspectiva. 1995; 9(3):17-23.

Ianni O. A sociedade global. Rio de Janeiro: Civilização Brasileira; 1992.

Ianni O. Teorias da globalização. Rio de Janeiro: Civilização brasileira. 2 a ed. 1996.

Ianni O. A cidade global. Petrópolis, RJ: Vozes; 1994. (Cultura Vozes, $\mathrm{n}^{\mathrm{o}}$ 2, mar.abr.).

Ianni $A M Z$. Meio ambiente e saúde na periferia da metrópole: Capela do Socorro, São Paulo. São Paulo; 1999. [Dissertação de Mestrado da Faculdade de Saúde Pública da USP].

Jacobi P. Moradores e meio ambiente na cidade de São Paulo; 1995. CEDEC. 43 (5). Rel. todo.

Jacobi P. Riscos Ambientais e a Construção da Cidadania. Debates Sócio Ambientais; 1996. 4.

Jacobi P. A Percepção dos Problemas Ambientais Urbanos em São Paulo. In: Ferreira LC e Viola E, organizadores. Incertezas de sustentabilidade na globalização. Campinas: Editora da Unicamp; 1996. p. 117-87.

Jacobi P. Educação para a cidadania: participação e co-responsabilidade. Debates Sócio Ambientais. 1997; (7):1-2.

Jodelet D. Civils et bredins: representations de la maladie mentale et raport a la folie en milieu rural. Paris; 1983. [These de Doctorat D'Etat École Hautes Étude in Sciences Sociales]. 
Kowarick L. Escritos urbanos. São Paulo: Editora 34, 2001.

Krasilchik $M$ et al. Projeto Temático de Equipe: Educação Ambiental Via Representações Acadêmicas e Populares do Meio. São Paulo: FAPESP; 1996.

Kuhnen A. Lagoa da Conceição: meio ambiente e modos de vida em transformação. Florianópolis: Cidade Futura; 2002.

Lago LC. Favela-loteamento: reconceituando os termos da ilegalidade e da segregação urbana. Cadernos Metrópole. 2003; 9: 119-33.

Laplantine F. Aprender antropologia. $3^{\text {a }}$ ed. São Paulo: Editora Brasiliense; 1988.

Lavinas L. Gênero, Cidadania e Políticas Urbanas In: Queiroz Ribeiro LC, Alves OASJ, organizadores. Globalização, fragmentação e reforma urbana. Rio de Janeiro: Editora Civilização Brasileira; 1994. p.169-87.

Leff E. Epistemologia ambiental. São Paulo: Cortez Editora; 2001.

Leonardi MLA. A sociedade global e a questão ambiental. In: Cavalcanti C, organizador. Desenvolvimento e natureza: estudos para uma sociedade sustentável. São Paulo: Cortez Editores; 1995. p. 195-207.

Lefebvre H. O pensamento marxista e a cidade. Povoa de Varzim: Ulissea, 1973.

Lefebvre H. O direito à cidade. $2^{\text {a }}$ ed. São Paulo: Centauro; 2001.

Loizos P. Vídeo, filme e fotografia como documento de pesquisa. In: Bauer MW, Gaskell G. Pesquisa qualitativa com texto, imagem e som: um manual prático. $2^{\text {a }}$ ed. Petrópolis, RJ: Editora Vozes; 2002.

Lüdke M. André MEDA. Pesquisa em educação: abordagens qualitativas. São Paulo: EPU; 1986.

Lutzenberg JA. Manifesto ecológico brasileiro. Fim do futuro? Porto Alegre: Editora Movimento; 1986.

Machado de Freitas C. Saúde ambiental e ciências sociais. [Apresentado no VII Congresso Latino Americano de Ciências Sociais e Saúde. Angra dos Reis, RJ; 2003 - mimeo].

McCormick J. Rumo ao paraíso: a história do movimento ambientalista. Rio de Janeiro: Relume Dumará; 1992.

Malinowski B. Objeto, Método e Alcance desta Pesquisa. In: Desvendando máscaras sociais. Rio de Janeiro: Livraria Francisco Alves Editora; 1975 p.39-61.

Maricato E. Metrópole periférica, desigualdade social e meio ambiente. In: Viana G, Silva $M$, Diniz N, organizadores. O desafio da sustentabilidade - um debate 
socioambiental no Brasil. São Paulo: Editora Fundação Perseu Abramo; 2001. p. 215-32.

Mello A. Mulheres em construção: casas, sonhos e subjetividade. São Paulo:EDUC; 1999.

Mendes EV. Uma agenda para a saúde. São Paulo: Editora Hucitec; 1996.

Miller KR. Evolução do conceito de área de proteção - oportunidades para o século XXI. In: I Congresso Brasileiro de Unidades de Conservação. Anais, vol. 1. Curitiba: IAP: UNILIVRE: Rede Nacional Pró Unidade de Conservação; 1997. p. 3-21.

Minayo MCS. Saúde-Doença: Uma concepção popular da Etiologia. Rev. Cad. Saúde Pública. 1988; 4(4): 363-81.

Minayo MCS. O Desafio do conhecimento: pesquisa qualitativa em saúde. São Paulo - Rio de Janeiro: Hucitec - Abrasco; 1996.

Ministério da Saúde. Promoção da saúde: carta de Ottawa, declaração de Adelaide, declaração de Sundsvall, declaração de Bogotá. Brasília; 1996.

Ministério da Saúde. Incentivo à participação popular e ao controle social no SUS, Brasília; 1994.

Monteiro CA. Velhos e novos males da saúde pública no Brasil - a evolução do país e de suas doenças. São Paulo: Hucitec; 1995.

Moraes EC. A construção do conhecimento integrado diante do desafio ambiental: uma estratégia educacional. In: Noal FO, Reigota M, Barcelos VHL, organizadores. Tendências da educação ambiental brasileira. Santa Cruz do Sul, RS: EDUNISC; 1998. 35-54.

Morin E, Kern AB. Terra pátria. Porto Alegre: Editora Sulina; 1995.

Moscovici S. Sociedade contra a natureza Petrópolis, RJ: Editora Vozes; 1975.

Moscovici S. A representação social da psicanálise. Rio de Janeiro: Zahar Editores; 1978.

Neves FA. Estudo da depressão circular da Colônia-SP pelo método sísmico. Instituto Agronômico e Geofísico, Universidade de São Paulo. Rev. Bras. Geociências; 1998. 28 (1):3-10.

Noal FO, Reigota M, Barcelos VHL, organizadores. Tendências da educação ambiental brasileira. Santa Cruz do Sul, RS: EDUNISC; 1998.

Ortiz R. A procura de uma sociologia da prática. In: Ortiz R, organizador, Fernandes F, coordenador. Pierre Bourdieu - Sociologia. São Paulo: Editora Ática; 1983. p. 7. (Grandes Cientístas Sociais, v.39). 
Ortiz R. Mundialização e cultura. São Paulo: Editora Brasiliense; 1994.

Organización Panamericana de La Salud. Promoción de la salud: una antología, Washington, D.C.; 1996.

Organização Panamericana da Saúde, Organização Mundial de Saúde. Divisão de Saúde e Ambiente. Atenção Primária Ambiental. Brasília; 1999.

Paehlke R. Environmentalism and the future of progressive politics. New Haven/London: Yale University Press; 1989.

Palos CMC. Meio ambiente e saúde em Espírito Santo do Turvo: um estudo das representações sociais das integrantes do movimento de mulheres. São Paulo; 2000. [Dissertação de Mestrado da Faculdade de Saúde Pública da USP].

Palos CMC, Mendes R. Problematização da educação ambiental através de oficina. In: Novos instrumentos de gestão ambiental urbana. São Paulo: EDUSP; 2001. (Acadêmica, 36). p. 55-69.

Parsons T. The Social System. Glencoe: Free Press; 1964.

Pasternak S. Um olhar sobre a habitação em São Paulo. Cadernos Metrópole; 2003. 9: 81-117.

Patton MQ. Qualitative evaluation methods. London: SAGE Publications; 1987.

Pinto CRJ Movimentos Sociais: Espaços Privilegiados da Mulher Enquanto Sujeito Político. In: Costa AO, Bruschini C, organizadores. Uma questão de gênero. São Paulo: Editora Rosa dos Tempos, Fundação Carlos Chagas; 1992. p. 127-150.

Philippi Jr A. Saneamento do Meio. São Paulo:Fundacentro; 1982.

[PMSP] Prefeitura do Município de São Paulo. Plano Diretor de Parelheiros Subprefeituras de Capela do Socorro e Parelheiros. São Paulo; 2004. [CD-ROM].

Radcliffe-Brown AR. A posição atual dos estudos antropológicos - Desvendando máscaras sociais. Rio de Janeiro: Livraria Francisco Alves Editora; 1975.

Redclift $M$. Development and environmental crisis: red or green alternatives. Nova Iorque: Methuen; 1984.

Redclift M, Woogate G. Sociology and the environment: discordant discurse? In: In: Redclift $\mathrm{M}$, Benton $\mathrm{T}$, editors. Social theory and the global environment. Londres e Nova Iorque: Routledge; 1994.

Redclift M, Woogate $G$, editores. The international handbook of environmental sociology. Edwaed Elgar. Cheltenham, Uk. Northampton, MA, USA; 1997.

Reigota M. Meio ambiente e representação social. São Paulo: Cortez; 1995. 
Reigota M. Educação ambiental: fragmentos de sua história no Brasil. In: In: Noal FO, Reigota M, Barcelos VHL, organizadores. Tendências da educação ambiental brasileira. Santa Cruz do Sul, RS: EDUNISC; 1998. p. 11-25.

Reigota M. Ecologia, elites e intelligentsia na América Latina: um estudo de suas representações sociais. São Paulo: AnnaBlume Editora; 1999.

Reigota M. A Floresta e a escola: por uma educação ambiental pós-moderna. São Paulo: Cortez; 1999.

Rey G. Pesquisa qualitativa em psicologia. Caminhos e desafios. São Paulo: Pioneira/Thonson Learning; 2002.

Riccomini C, Neves F, Turcq B. Astroblema de Colônia (São Paulo, Brasil): Estágio atual de conhecimento. [Trabalho apresentado no $37^{\circ}$ Congresso Brasileiro de Geologia - SBG/SP, São Paulo; 1992 - mimeo].

Rodrigues AM. Produção e consumo no espaço - problemática ambiental urbana. São Paulo: Editora Hucitec; 1998.

Rosen G. Uma história da Saúde Pública. São Paulo: UNESP/HUCITEC/ABRASCO; 1994.

Rolnik R, Saule Júnior N. Habitat II - assentamentos humanos como tema global. In: Bonduki, N, organizador. Habitat: as práticas bem sucedidas em habitação, meio ambiente e gestão urbana nas cidades brasileiras. São Paulo: Studio Nobel; 1996.

Rosa JG. Grande Sertão: Veredas. $20^{\mathrm{a}}$ ed. Rio de Janeiro: Livraria Nova Fronteira; 1986.

Sá CP de. Representações Sociais: o conceito e o estado atual da teoria. In: Spink MJ, organizador. O Conhecimento no cotidiano: as representações sociais na perspectiva da psicologia social. São Paulo: Editora Brasiliense; 1993. 19-45.

Sachs I. Estratégias de transição para o Século XX. In: Bursztyn M, organizador. Para pensar o desenvolvimento Sustentável. $2^{\text {a }}$ ed. São Paulo: Editora Brasiliense; 1994. 29-56.

Sachs I. Desenvolvimento numa Economia Mundial Liberalizada e Globalizante: um desafio impossível? Rev Estudos Avançados. 1997; 2(30): 213-42.

Sacks I. Desenvolvimento, direitos humanos e cidadania. In: Pinheiro OS, Guimarães SP. Direitos humanos no século XXI. Brasília: IPRI; 1998. 155-66.

Santos BS. Pela mão de Alice: o social e o político na pós-modernidade. São Paulo: Cortez Editora; 1995. 
Santos BS. A Construção Multicultural da Igualdade e da Diferença. [Palestra proferida no VII Congresso Brasileiro de Sociologia, realizado no Instituto de Filosofia e Ciências Sociais da Universidade Federal do Rio de Janeiro; 1995].

Santos BS. Um discurso sobre as ciências. $13^{\mathrm{a}}$ ed. Porto: Edições Afrontamento; 2002.

Santos M. Espaço e Sociedade. Petrópolis, RJ: Vozes; 1979.

Santos M. A Urbanização brasileira. São Paulo: Hucitec; 1993.

Santos M. Técnica, espaço, tempo: globalização e meio técnico científicoinformacional. São Paulo: Hucitec; 1994.

Santos M. A natureza do espaço: técnica e tempo - razão e emoção. $2^{a}$ ed. São Paulo: Hucitec; 1997.

Sawaia BB. Representação e Ideologia - o encontro desfetichizador. In: Spink MJ, organizador. O Conhecimento no cotidiano: as representações sociais na perspectiva da psicologia social. São Paulo: Editora Brasiliense; 1993. p. 73-84.

Sawaia BB. A Consciência em construção no trabalho de construção da existência. São Paulo; 1987. [Tese de Doutorado em Psicologia Social - PUC].

Scherer-Warren I. Cidadania sem Fronteiras: Ações Coletivas na Era da Globalização. São Paulo: Editora Hucitec; 1999.

Severino AJ. Metodologia do trabalho científico. $21^{\text {a }}$ ed. São Paulo: Cortez; 2000.

Singer P. Globalização e desemprego: diagnóstico e alternativas. São Paulo: Contexto; 1998.

Soares LTR. Ajuste neoliberal e desajuste social na América Latina. Rio de Janeiro: Editora Anna Néri URFJ; 1998.

Sobral HR. Meio Ambiente e Governos locais. São Paulo em perspectiva. 1992; 6 (1-2):76-78.

Sobral HR. Globalização e meio ambiente. In: Dowbor L, Ianni O, Resende PEA, organizadores. Desafios da globalização. $2^{a}$ ed. Petrópolis, RJ: Editora Vozes; 1997. p. 140-6.

Sorrentino M, Tassara ETO. Educando para o desenvolvimento sustentável. In: O município no século XXI: cenários e perspectivas. São Paulo: Fundação Prefeito Faria Lima-Cepam; 1999. p.185-90.

Spaargaren G, Mol APJ. Sociology, environment and modernity: ecological modernization as a theory of social change. Society \& Natural Resources. 5:323$44 ; 1992$. 
Sposati A, coordenador. Mapa da inclusão/exclusão social em São Paulo. Núcleo de Seguridade e Assistência Social do Programa de Estudos de Pós-Graduação em Serviço Social da PUC/SP. São Paulo (CD-ROM); 1996.

Spink MJP. O estudo empírico das representações sociais. In: O Conhecimento no cotidiano: as representações sociais na perspectiva da psicologia social. São Paulo: Editora Brasiliense; 1993. p. 85-108.

Spink MJP, Frezza RM. Práticas discursivas e produção de sentidos: a perspectiva da psicologia social. In: Spink MJP, organizador. Práticas discursivas e produção de sentidos no cotidiano: aproximações teóricas e metodológicas. São Paulo: Cortez Editora; 1999. p. 17-40.

Spink MJP, Medrado B. Produção de sentidos no cotidiano: uma abordagem teóricometodológica para análise das práticas discursivas. In: Spink MJP, organizador. Práticas discursivas e produção de sentidos no cotidiano: aproximações teóricas e metodológicas. São Paulo: Cortez Editora; 1999. p. 41-62.

Spink MJP, Menegon VM. A Pesquisa como prática discursiva: superando os horrores metodológicos. In: Spink MJP, organizador. Práticas discursivas e produção de sentidos no cotidiano: aproximações teóricas e metodológicas. São Paulo: Cortez Editora; 1999. p. 63-92.

Spink MJP e Frezza RM. Abordando imagens como linguagem em uso. [Texto apresentado na Mesa Redonda: Linguagem: alternativas e metodológicas para análise no campo da saúde. Laboratório de Pesquisas sobre Práticas de Integralidade em Saúde, LAPPIS. Rio de Janeiro; 2003].

Spink P. Análise de documentos de domínio público. In: Práticas discursivas e produção de sentidos no cotidiano: aproximações teóricas e metodológicas. São Paulo: Cortez Editora; 1999. p. 123-51

Stahel AW. Capitalismo e entropia: os aspectos ideológicos de uma contradição e a busca de alternativas sustentáveis. In: Cavalcanti $\mathrm{C}$, organizador. Desenvolvimento e natureza: estudos para uma sociedade sustentável. São Paulo: Cortez Editores; 1995. p. 104-27.

[SVMA] Secretaria Municipal do Verde e do Meio Ambiente. Prefeitura Municipal de São Paulo. Departamento de Educação Ambiental e Planejamento. Área de Preservação Ambiental Municipal do Capivari-Monos-Caracterização SócioAmbiental - Relatório Preliminar; 1998. Disponível em: <URL: http//www.prefeitura.sp.gov.br>.

Tassara ETO, Rabinovich EP. A invenção do urbano e o poético: uma cartografia afetiva: estudo sobre o bairro paulistano da Barra Funda. In: Tassara ETO, organizadora. Panoramas interdisciplinares para uma psicologia ambiental do urbano. São Paulo: EDUC-FAPESP; 2001. p. 211-67. 
Tassara ETO, Rabinovich EP, Goubert JP. O lugar da poética nas relações pessoaambiente. O caso da Barra Funda: uma arqueologia de um elo social em vias de desaparecimento; 2003. Mimeo. p. 9.

Telles VS. Questão Social: Afinal de que se trata?. São Paulo em Perspectiva; 1996. 10(4):85-95.

Tiezzi E. Tempos históricos, tempos biológicos. São Paulo: Nobel; 1988.

Touraine A. Poderemos viver juntos? Iguais e diferentes. $21^{\mathrm{a}}$ ed. Petrópolis, RJ: Editora Vozes; 1999.

Thomas K. O homem e o mundo natural. São Paulo: Companhia das Letras; 1983.

Véras, MPB. Trocando olhares - uma introdução sociológica da cidade. São Paulo: EDUC-Studio Nobel; 2000.

Véras MPB. DiverCidade: territórios estrangeiros como topografia da alteridade em São Paulo. São Paulo: EDUC; 2003.

Victorino VIP. Os desafios sociais da questão ambiental: proteção das águas e luta por moradia na Cratera da Colônia. São Paulo; 1996. [Dissertação de Mestrado da Faculdade Ciências Sociais da PUC].

Vieira PV. A problemática ambiental e as ciências sociais no Brasil: 1980-1990. ANPOCS, 1992. 33:3-32.

Vieira PF. Apresentação. In: Leff E. Epistemologia ambiental. São Paulo: Cortez; 2001.p. 9-15.

Viezzer M. O problema não está na mulher. São Paulo: Cortez; 1989.

Viola E. A multidimensionalidade da globalização, as novas forças sociais transnacionais e seu impacto na política ambiental no Brasil, 1989-1995. In: Ferreira LC, Viola E, organizadores. Incertezas de sustentabilidade na globalização. Campinas: Editora da UNICAMP; 1996. p. 15-65.

Yearley S. The green case: a sociology of environmental issues, arguments and politics. Londres: Routledge; 1992.

Yearley S. Sociology, environmentalism, globalization. London: SAGE Publications; 1996.

Wagner W. Sócio-Gênese e Características das Representações Sociais. In: Paredes Moreira AS e Oliveira DC, organizadores. Estudos interdisciplinares de representação social. Goiânia: AB Editora; 1998.

Wiener CL. The politics of alcoholism: building an Arena around a social. New Brunswick, NJ: Transaction; 1981. 
Anexo 1 - Termo de Consentimento 


\section{TERMO DE CONSENTIMENTO LIVRE E ESCLARECIDO}

Título da Pesquisa: Vozes da Cratera: representações, sentidos, significados e práticas da questão socioambiental no cenário urbano

Prezada senhora, prezado senhor:

Este estudo que está sendo realizado pela pesquisadora Cássia Maria Carraco Palos, aluna de pós-graduação, nível de doutorado, na área de concentração de Serviços de Saúde Pública da Faculdade de Saúde Pública da Universidade de São Paulo, tendo como orientadora a Profa. Dra. Fabiola Zioni, objetiva compreender a problemática ambiental na cidade de São Paulo, a partir dos depoimentos de mulheres e de discussões em grupos.

Também tem por finalidade contribuir para a promoção da saúde, melhoria da qualidade ambiental, ampliação do campo de conhecimento e ainda, a obtenção do título de doutora em Saúde Pública.

Desta forma, solicita de V.Sa. permissão para entrevistá-la (o) individualmente e gravar essa entrevista para ser posteriormente transcrita. A pesquisadora compromete-se manter o anonimato dos nomes das participantes, se assim for solicitado. Também garante que a entrevistada pode a qualquer tempo, no decorrer do trabalho, modificar, solicitar informações, ter acesso ao material transcrito, suspender e/ou desistir da pesquisa, sem qualquer tipo de constrangimento pessoal ou profissional.

A pesquisadora compromete-se, quando solicitada, a retornar cópia do material transcrito relativo às falas individuais ou coletivas, ou mesmo, fornecer cópia da tese concluída, para tanto disponibilizará uma via deste documento a cada um dos participantes, na qual faz constar os dados que permitem contactá-la.

Caso a entrevistada não concorde em assinar este documento, porém aceite participar da pesquisa, somente o assinarão a entrevistadora e sua orientadora.

Por acreditar que a contribuição de todos as integrantes da pesquisa é de fundamental importância para este trabalho, desde já agradece a atenção.

De acordo:

Pesquisadora:

Cássia Maria Carraco Palos

RG: 10.479.139

Rua Quirino Pucca, 197-Vila Romana, São Paulo, SP.

E-mail: cpalos@usp.br

Fone: 36728467

Nome da entrevistada:

Telefone: 
Anexo 2-Roteiro da Entrevista 


\section{ROTEIRO DA ENTREVISTA:}

\section{VOZES DA CRATERA: REPRESENTAÇÕES, SENTIDOS, SIGNIFICADOS E PRÁTICAS DA QUESTÃO SOCIOAMBIENTAL NO CENÁRIO URBANO.}

\section{Dados Pessoais:}

Nome da entrevistada/Entrevistado:

Endereço:

Idade:

Profissão:

Etnia:

\section{Informações Gerais:}

Há quanto tempo reside na região:

Procedência:

Motivo da vinda:

Você participa de alguma associação? Qual?

Você já participou ou participa de algum curso de educação ambiental? Onde?

\section{Ocupação}

Está empregada/o atualmente?

Renda média da família: (Responda se quiser)

Ocupação das pessoas que recebem remuneração:

Local de trabalho:

Que transporte usa?

\section{Habitação}

Tempo e ocupação da moradia?

É proprietária/o?

Quanto paga de aluguel?

Quantas pessoas residem na casa? 


\section{Representações sociais sobre ambiente (Entrevista Aberta)}

1. Para você, o que significa ambiente?

2. Para você o que são problemas ambientais?

3. Você conseguiria citar cinco exemplos de problemas ambientais? Quais

4. No seu entender existem problemas ambientais aqui na Cratera? Quais?

5. Estes problemas citados te afligem ou de incomodam de alguma maneira?Por quê?

6. Quem, no seu entender, são os responsáveis pelos problemas ambientais?

7. Quem seriam os responsáveis pela solução desses problemas?

8. Para você existe alguma relação entre pobreza e problemas ambientais?

9. Para você existe alguma relação entre riqueza e problemas ambientais?

10. De que maneira você acha que as pessoas podem colaborar para a conservação do ambiente em que vivem?

11. O que você tem feito para melhorar e/ou conservar o ambiente em que vive?

12. Você costuma ter informações a respeito do ambiente? Por meio do que?

13. Para você o que é saúde?

14. Para você existe relação entre problemas ambientais e saúde?

15. Você conhece a história da Cratera?

16. Você sabe o que é uma APA (Área de Proteção Ambiental )? 
Anexo 3 - Painel Fotográfico 

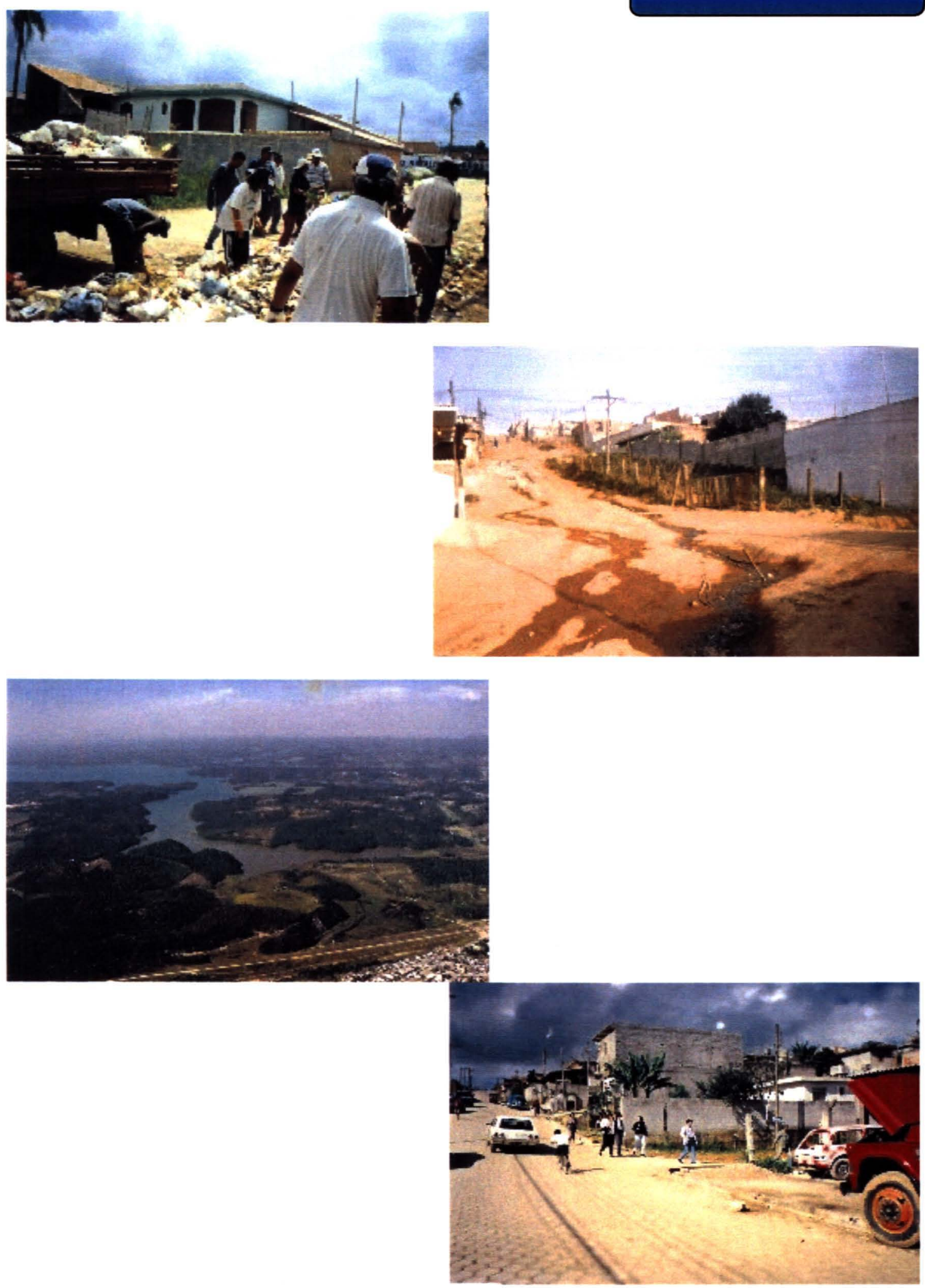


\section{GRUPO 2}
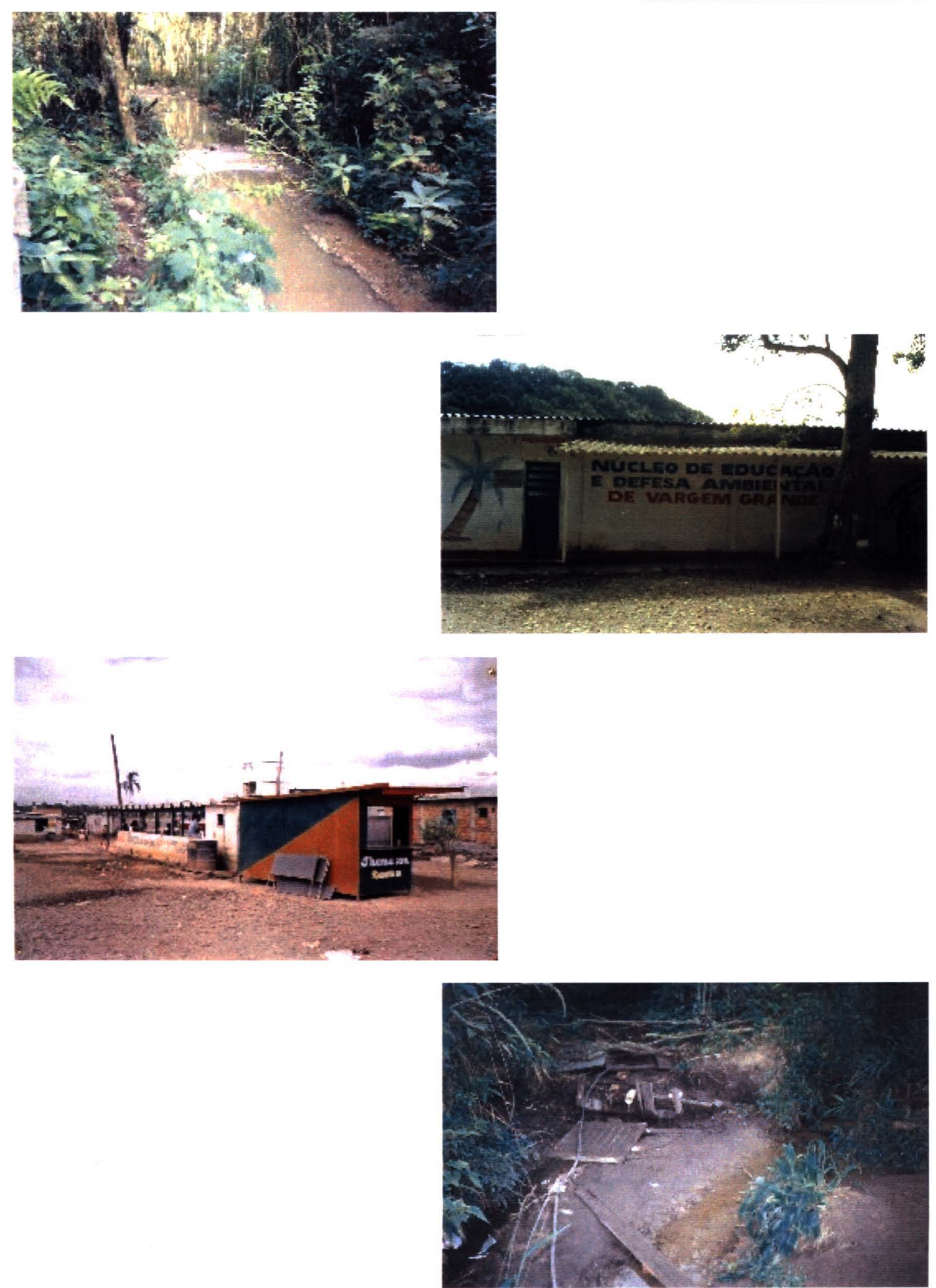


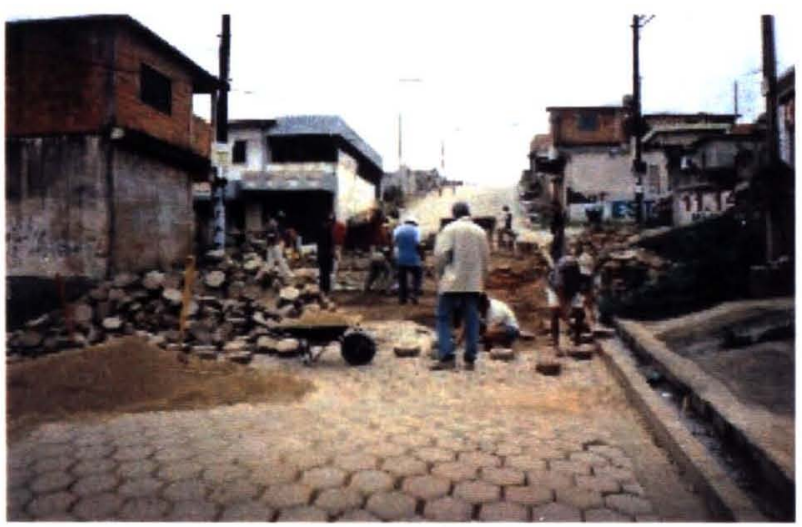

\section{GRUPO 3}
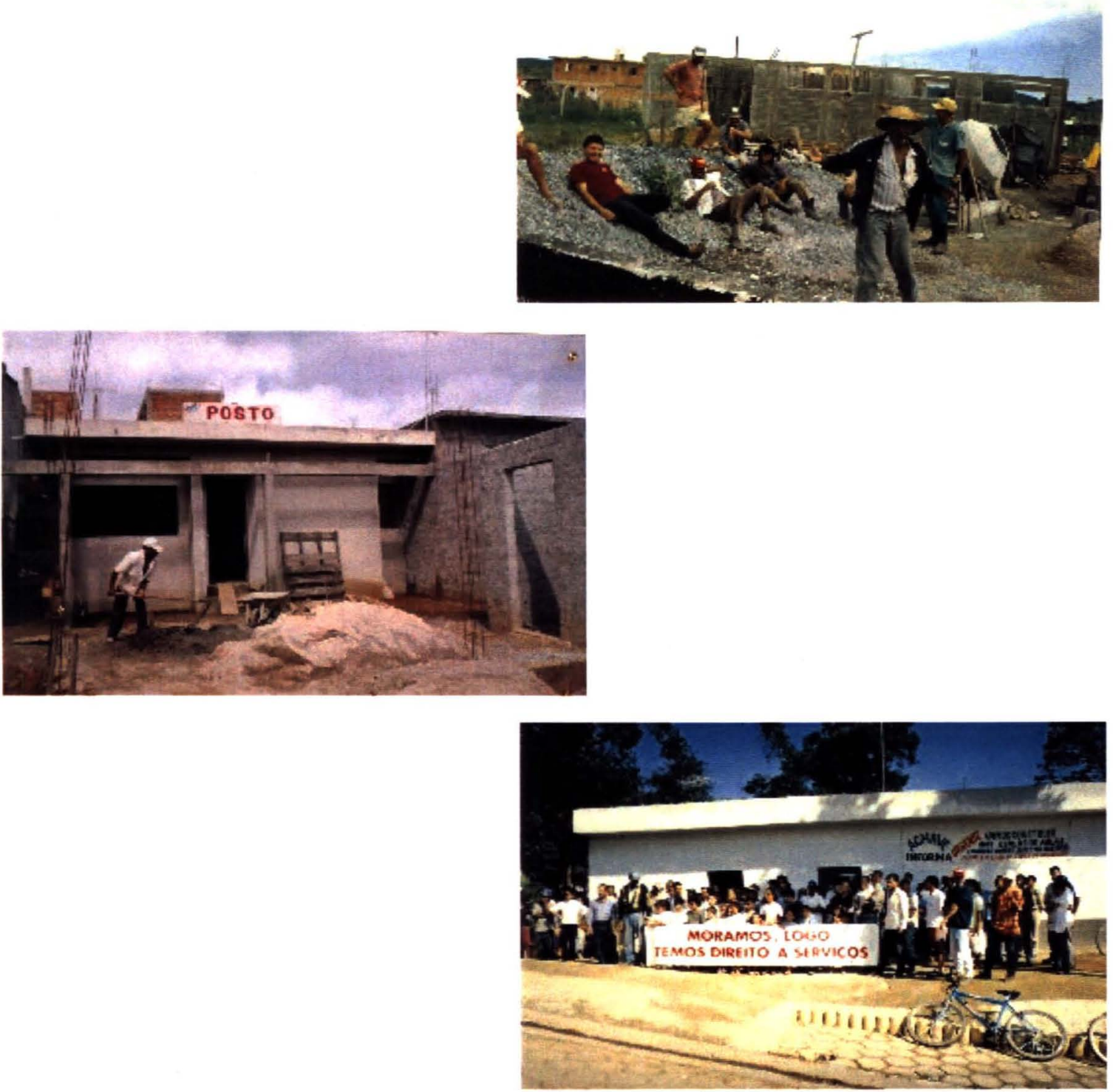

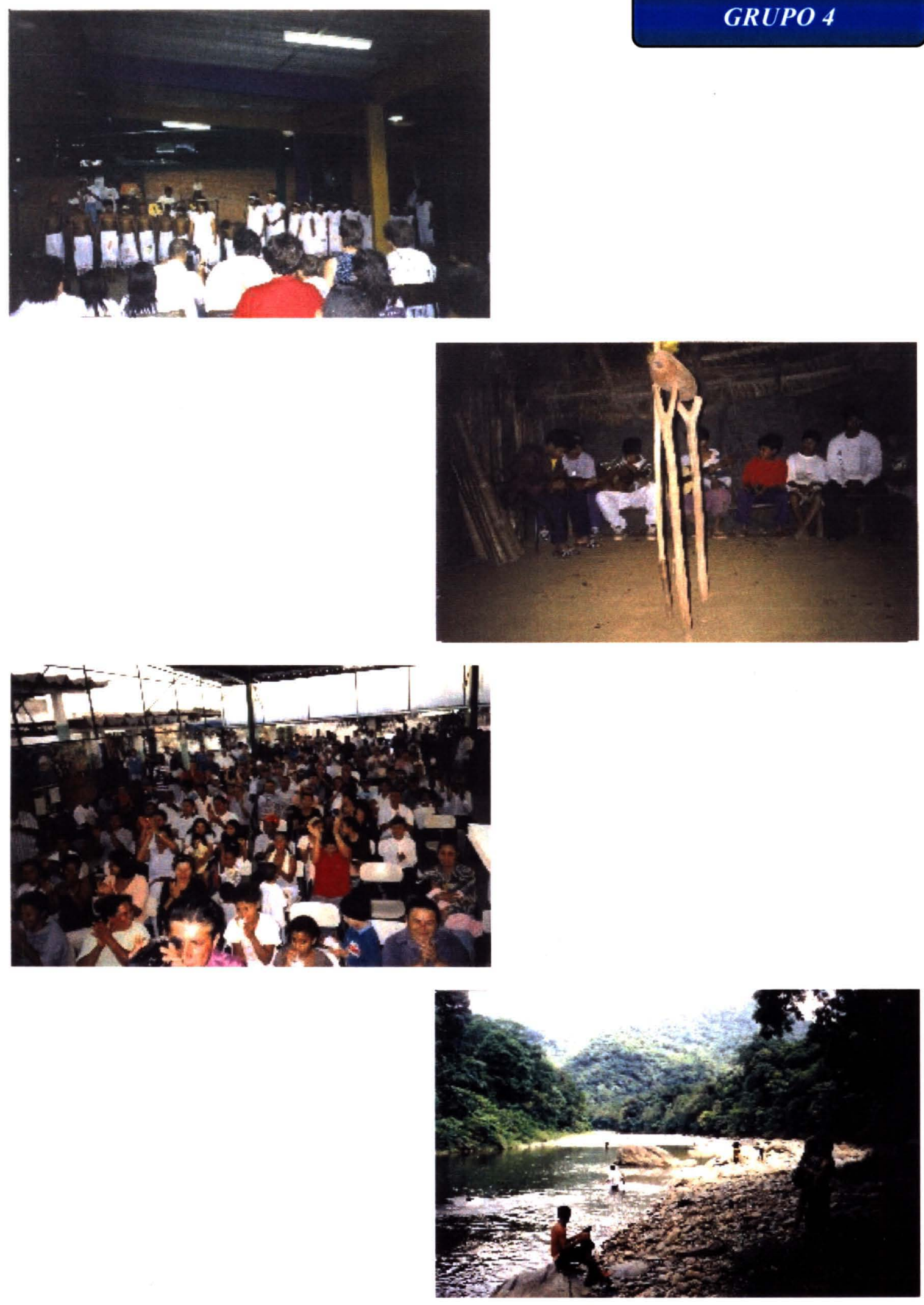


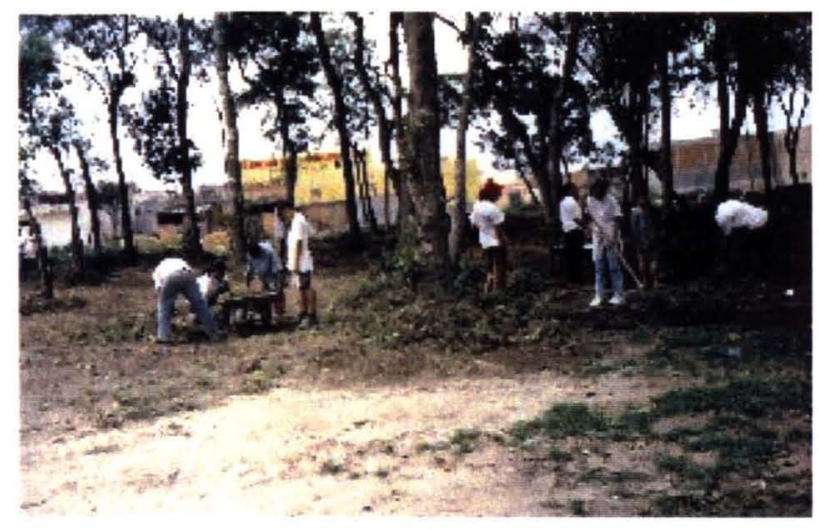

GRUPO 5
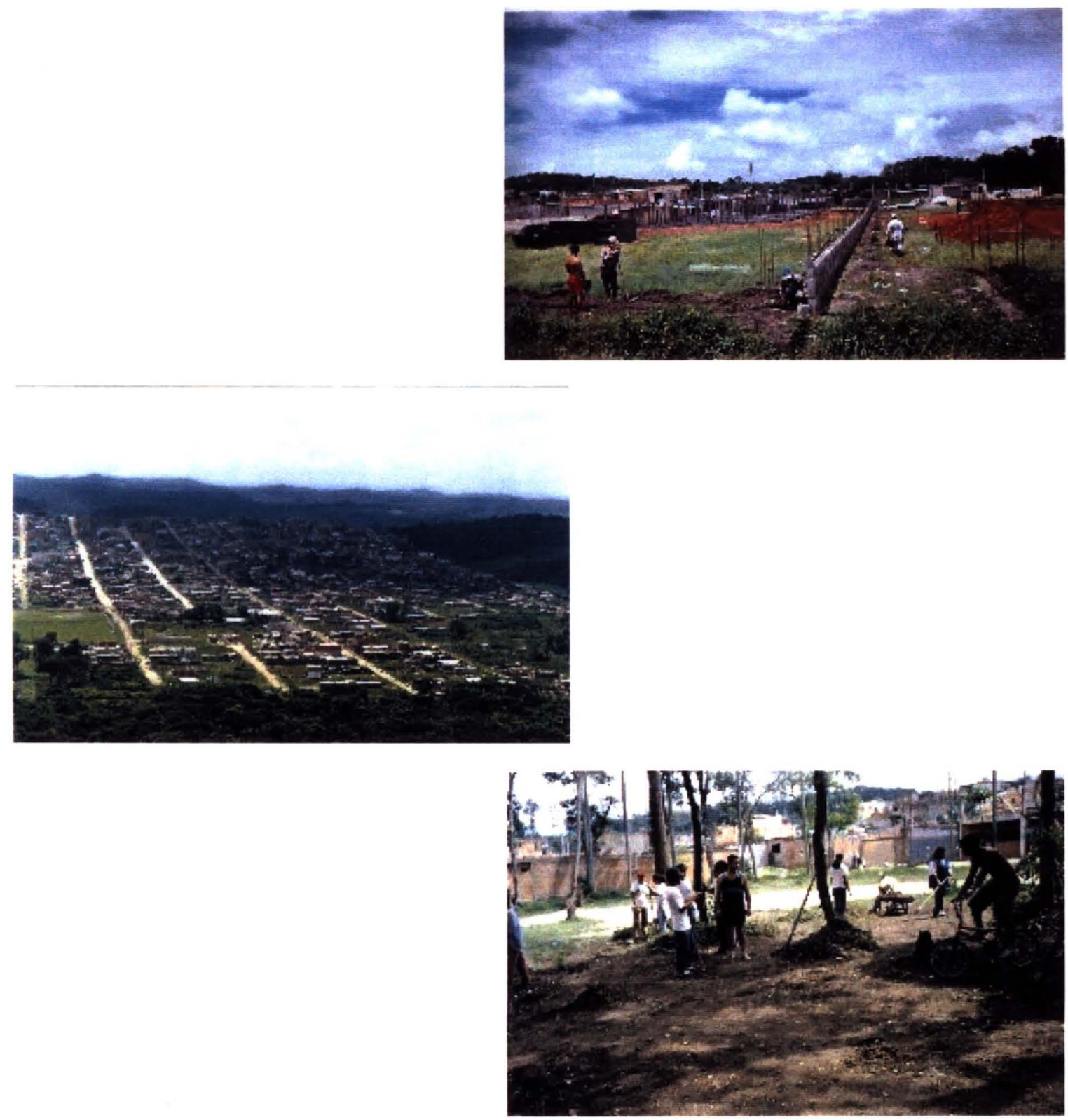


\section{GRUPO 6}
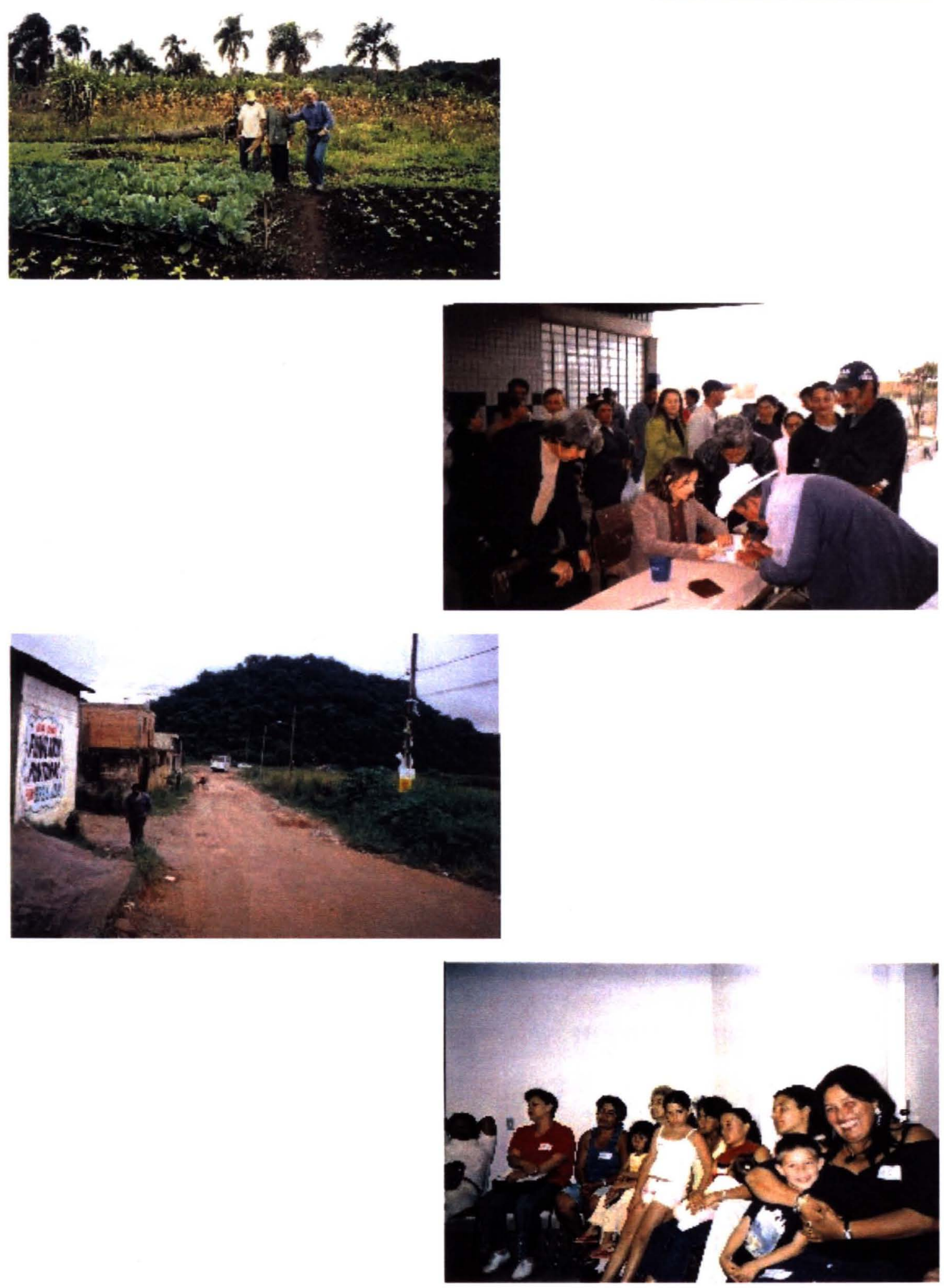


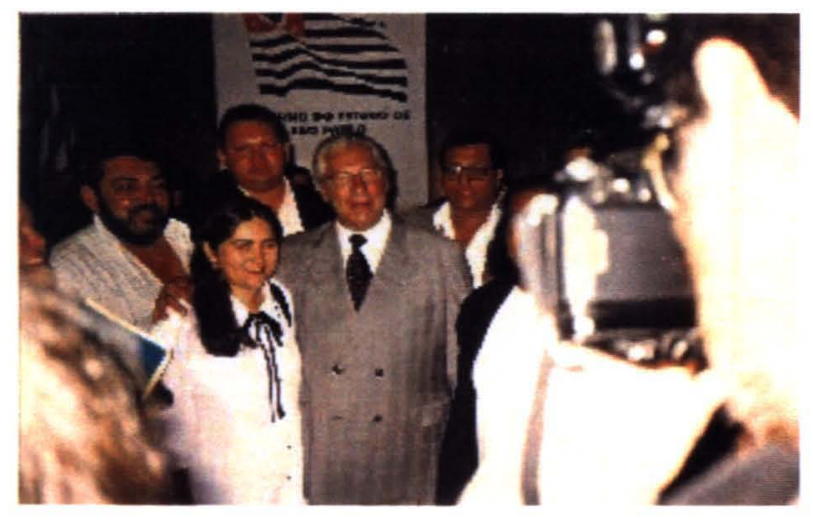

GRUPO 7
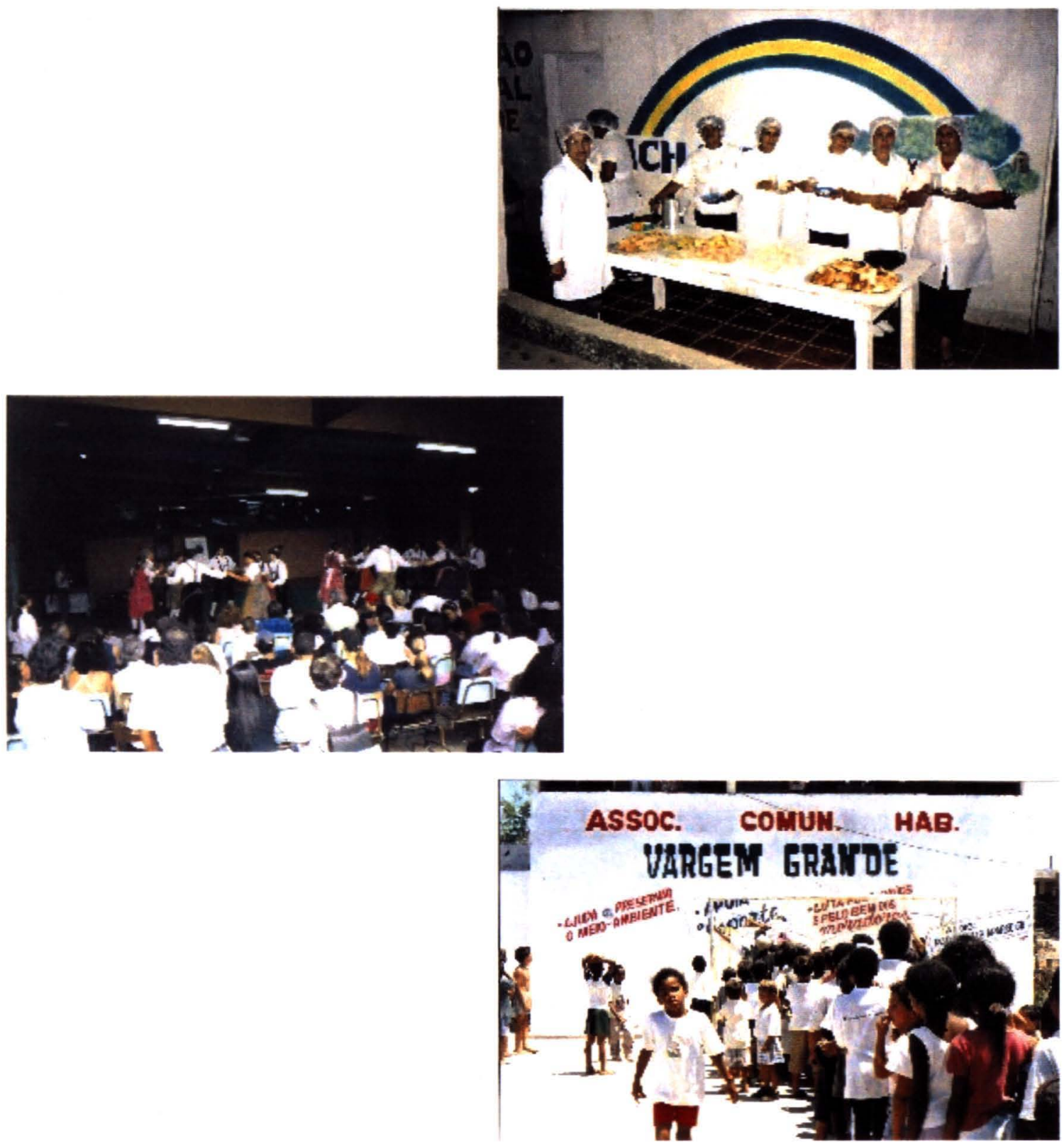

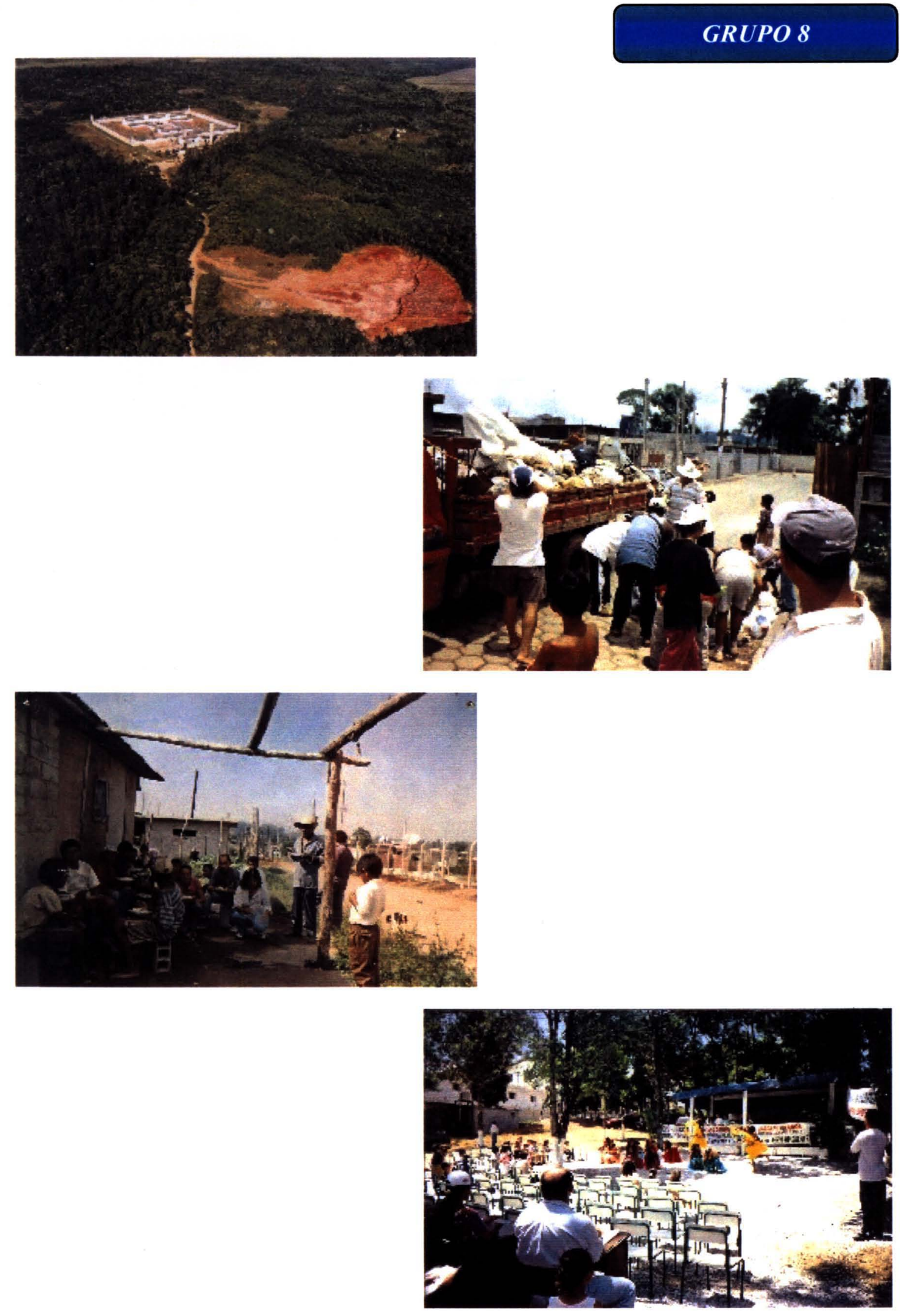

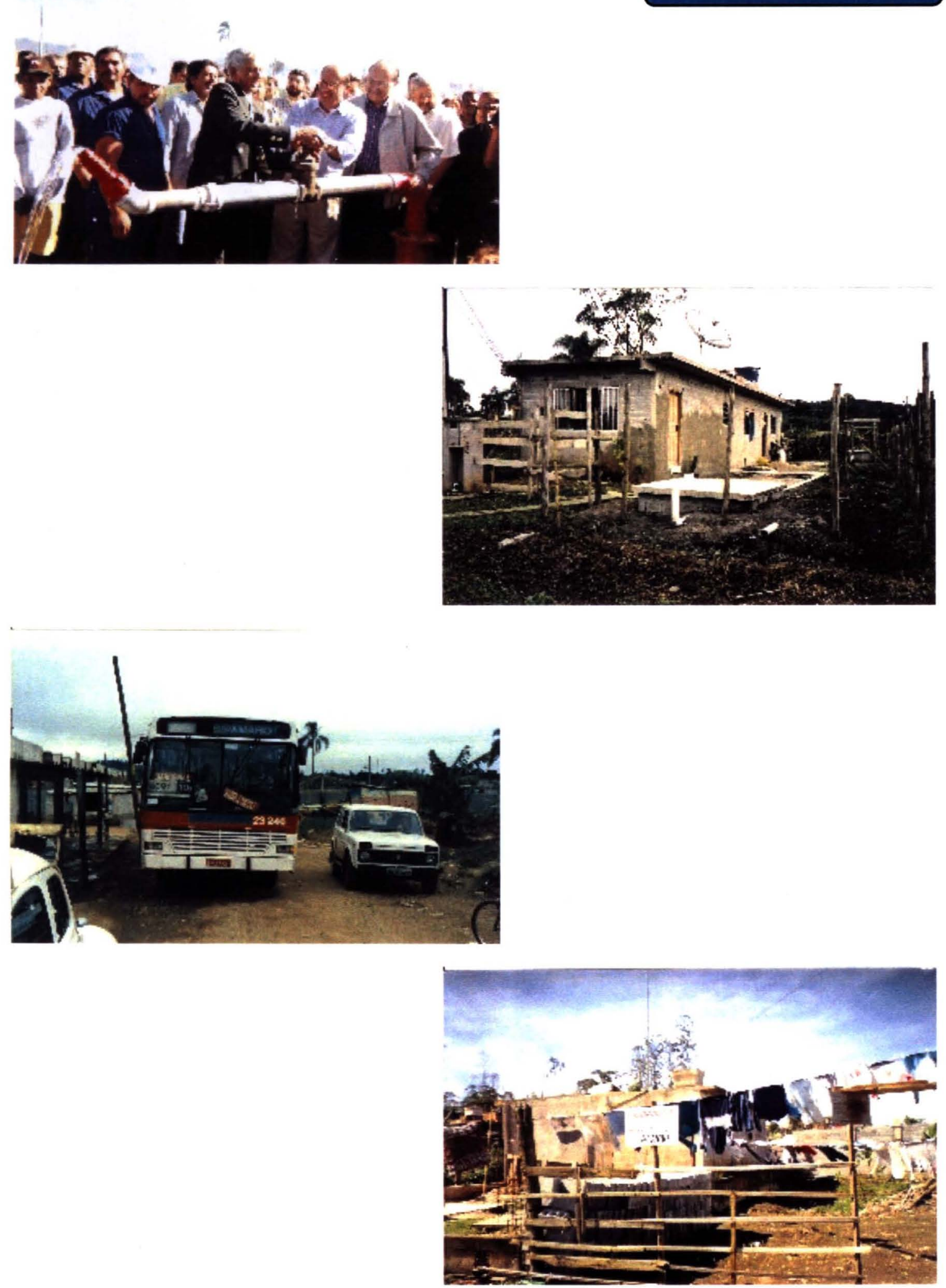


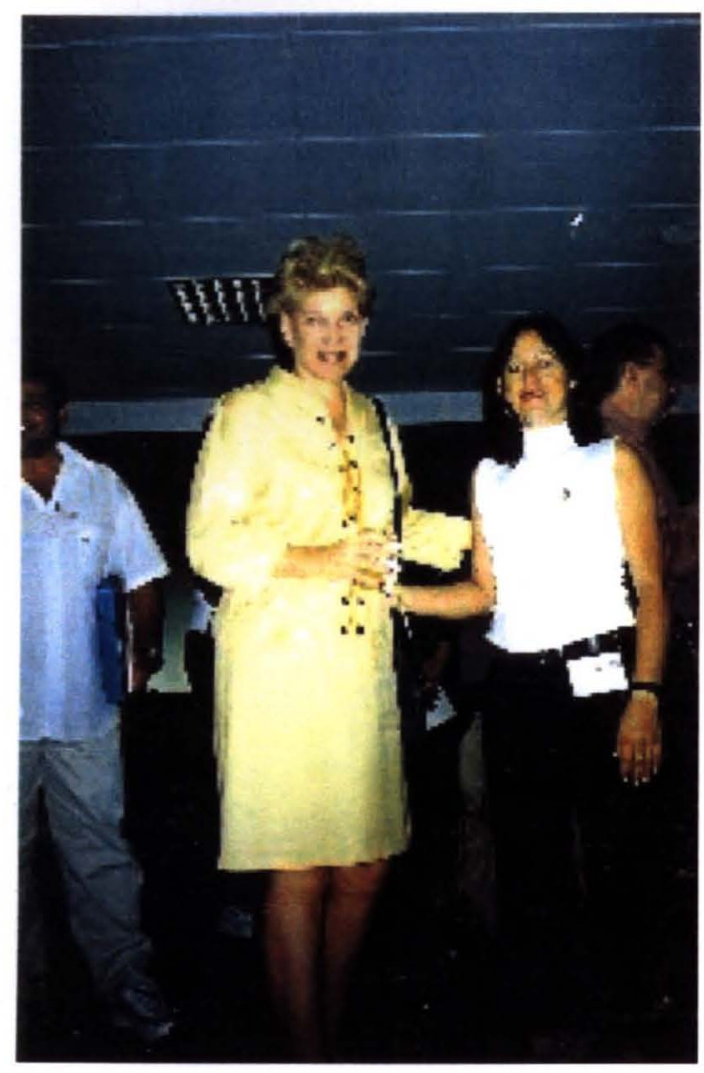

GRUPO 10

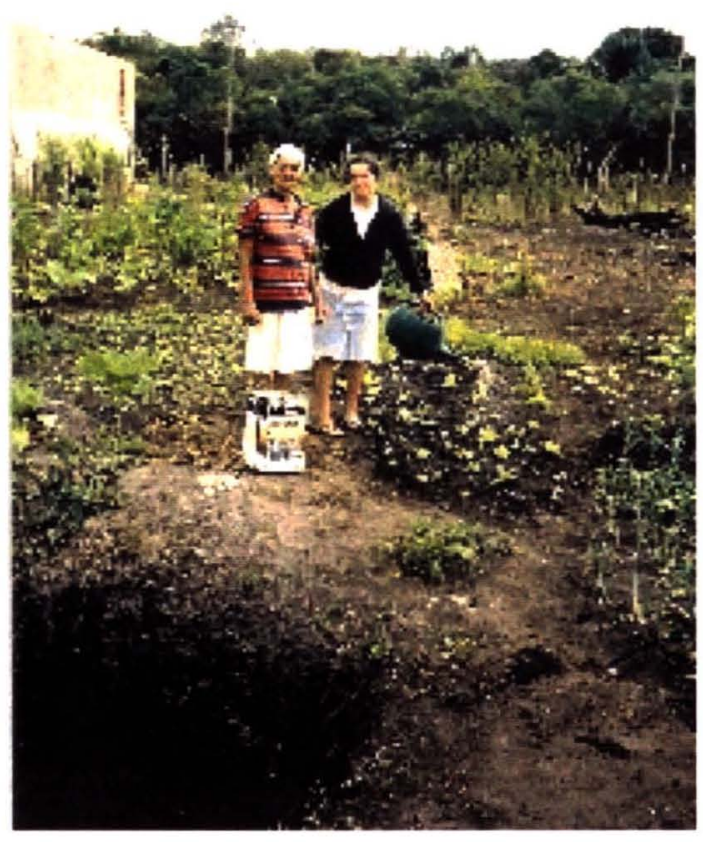

